UNIVERSIDADE DE SÃO PAULO

FFCLRP - DEPARTAMENTO DE PSICOLOGIA E EDUCAÇÃO

PROGRAMA DE PÓS-GRADUAÇÃO EM PSICOLOGIA

Fatores emocionais durante uma escuta musical afetam a percepção temporal de músicos e não músicos?

\title{
Danilo Ramos
}

Tese apresentada à Faculdade de Filosofia, Ciências e Letras de Ribeirão Preto da USP, como parte das exigências para a obtenção do título de Doutor em Ciências, Área: Psicologia.

RIBEIRÃO PRETO - SP 
UNIVERSIDADE DE SÃO PAULO

FFCLRP - DEPARTAMENTO DE PSICOLOGIA E EDUCAÇÃO

PROGRAMA DE PÓS-GRADUAÇÃO EM PSICOLOGIA

Fatores emocionais durante uma escuta musical afetam a percepção

temporal de músicos e não músicos?

Danilo Ramos

Orientador: Prof. Dr. José Lino Oliveira Bueno

Tese apresentada à Faculdade de Filosofia, Ciências e Letras de Ribeirão Preto da USP, como parte das exigências para a obtenção do título de Doutor em Ciências, Área: Psicologia.

RIBEIRÃO PRETO - SP 
AUTORIZO A REPRODUÇÃO E DIVULGAÇÃO TOTAL OU PARCIAL DESTE TRABALHO, POR QUALQUER MEIO CONVENCIONAL OU ELETRÔNICO, PARA FINS DE ESTUDO E PESQUISA, DESDE QUE CITADA A FONTE.

\section{FICHA CATALOGRÁFICA}

\section{Ramos, Danilo}

Fatores emocionais durante uma escuta musical afetam a percepção temporal de músicos e não- músicos? Danilo Ramos; orientador José Lino Oliveira Bueno. Ribeirão Preto, 2008.

$268 \mathrm{f:} \mathrm{fig.}$

Tese (Doutorado - Programa de Pós-Graduação em Psicologia. Área de Concentração: Psicologia da Música) Faculdade de Filosofia, Ciências e Letras de Ribeirão Preto. Universidade de São Paulo.

1. Emoções musicais. 2. Percepção temporal. 3. Expertise musical. 4. Cognição musical. 


\section{FOLHA DE APROVAÇÃo}

\section{Danilo Ramos}

Fatores emocionais durante uma escuta musical afetam a percepção temporal de músicos e não músicos?

Tese apresentada à Faculdade de Filosofia, Ciências e Letras da Universidade de São Paulo para a obtenção do título de Doutor.

Área de Concentração: Psicologia da Música

Aprovado em:

de de 2008 .

Banca Examinadora

Prof. Dr.

Instituição: Assinatura:

Prof. Dr.

Instituição: Assinatura:

Prof. Dr.

Instituição: Assinatura:

Prof. Dr.

Instituição: Assinatura:

Prof. Dr.

Instituição: Assinatura: 


\section{DEDICATÓRIA}

Dedico este trabalho:

À minha mãe Zenilda Maria Silva Ramos, pelo amor incondicional.

Ao meu pai Nilton Ramos, pela segurança transmitida nos momentos mais difíceis.

Aos meus irmãos Nilton Ramos Júnior e Érica Ramos e sobrinhos Arthur Henrique Ramos e Ana Júlia Ramos, pelo constante incentivo.

Aos grandes e inigualáveis amigos Bruno Kriesel Passos, Nestor Müeller e Adriane Cristina Torrieri, por terem sido os verdadeiros sustentáculos de minhas idéias e vontades durante toda a pós-graduação.

E, finalmente, a todos os pesquisadores interessados no estudo sistemático sobre o poder que a música tem em fazer as pessoas felizes.

A vocês, o meu muito obrigado pela realização de mais este sonho. 


\section{AgRAdecimentos}

Agradeço de forma especial:

Ao Professor José Lino Oliveira Bueno pela orientação amiga, precisa e segura com que me guiou no desenvolvimento deste trabalho.

Aos Professores Beatriz Senói Ilari e José Francisco Miguel Henriques Bairrão pelas sugestões apresentadas por ocasião do exame de qualificação.

Ao querido amigo e professor Emmanuel Bigand, pela contribuição ímpar na metodologia e análise de dados.

Ao grande amigo e técnico laboratorial João Lúis Segala Borin pela amizade e pela verdadeira assessoria dada durante toda a pós-graduação.

A Raquel Cocenas da Silva, pela amizade sincera, pela ajuda na coleta de dados e, principalmente, por transmitir-me paz e segurança nos momentos mais tensos.

Aos amigos de laboratório Érico, Francisco, Alexandre, Sarah, Valéria, Taíza, Danielle,

Tatiana, Alessandra, Lézio, Eduardo, Mariana, Nathália e Vinícius, pela constante disposição em dar um sorriso, uma sugestão ou um incentivo.

A Daniela Huayna Naldi de Aguiar Falleiros, pela confecção do desenho da capa do presente trabalho.

Ao amigo Leonardo de Oliveira Freitas, pelo auxílio na confecção das partituras musicais ilustradas no decorrer de todo o trabalho.

A Aída Rosa Conci, pela revisão gramatical do presente trabalho.

A Karen Christina Justino Kroll, pela revisão do inglês do abstract do presente trabalho.

A todos vocês os meus sinceros agradecimentos. 


\section{EPÍGRAFE}

\section{Estes tuiuiús...}

"Quando eu era criança, o meu pai costumava assobiar em meus ouvidos para me fazer dormir. E eu só conseguia dormir por causa disso. Minha mãe até que tentava, com muito esforço, mas quando me colocava no berço, eu arregalava os olhos e chorava, pedindo colo novamente. Os tios me dizem que era muito engraçado... É que o meu pai tinha a mágica de imitar o canto dos tuiuiús. Era lindo! Aquele som vibrava, penetrava em minha mente e eu dormia, serena e profundamente... Acho que é por isso que até os dias de hoje o meu sono é extremamente profundo, pode cair o mundo que eu não acordo!

Quando eu era adolescente, eu ficava procurando o mesmo som dos tuiuiús nas ruas perto de minha casa, enquanto eu brincava. E teve um dia que eu o encontrei. Este som vinha de uma das casas da redondeza, que tinha aspecto antigo e um cheirinho muito gostoso de bolo fresco, em cujo ar transparecia toda a serenidade que ali habitava. Neste dia havia alguém tocando um piano, tateando um "vibrato" com um sentimento tão profundo, que creio ter conseguido deixar o velho mestre Chopin se contorcendo de inveja em seu caixão. Neste dia, eu deixei os meus amiguinhos brincando na rua e ajoelhei-me no portão daquela casa. Fiquei ouvindo aquele som gostoso que entrava em mim como uma luva, como um espírito, como uma espécie de armadura.

E alguns anos após este dia, eu já era um pianista formado, bacharel em Música pela Unicamp, mestre em Psicologia (da Música) pela USP, um ser absolutamente apaixonado e realizado pela profissão que escolheu.

E hoje, trinta anos após os primórdios do inigualável som dos tuiuiús, eu realizo mais um grande sonho: o de tornar-me Doutor em Cognição Musical pela USP, no intuito de dedicar toda a minha vida à pesquisa científica sobre os tuiuiús que costumam rondar a mente e a alma das pessoas." 
1. INTRODUÇÃO ..........................................................................................................................19

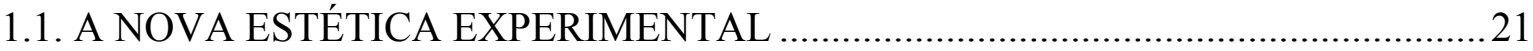

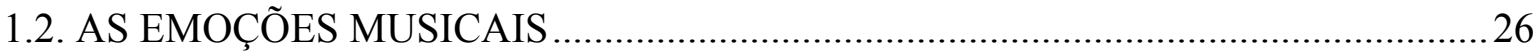

1.2.1. A EXPRESSÃO “EMOÇÃO MUSICAL” ..........................................................28

1.2.2. METODOLOGIAS EMPREGADAS PARA MENSURAR AS EMOÇÕES

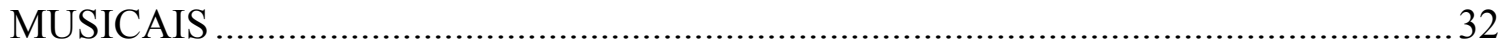

1.2.3. TEORIAS E MODELOS SOBRE A PERCEPÇÃO DAS EMOÇÕES

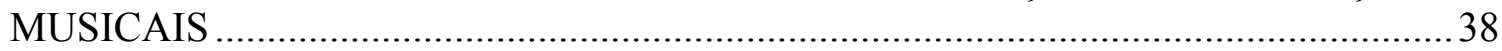

1.2.4. O USO DO MODO E DO ANDAMENTO MUSICAL EM PESQUISAS SOBRE AS EMOÇÕES MUSICAIS ...........................................................................

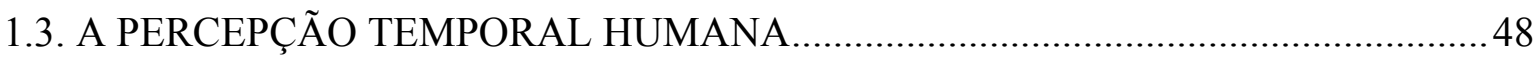

1.3.1. PRINCIPAIS MODELOS SOBRE O PROCESSAMENTO TEMPORAL

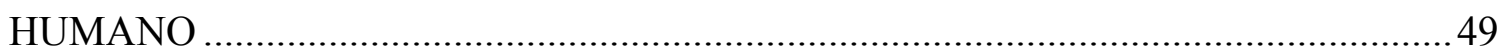

1.3.2. METODOLOGIAS EMPREGADAS PARA MENSURAR A PERCEPÇÃO TEMPORAL HUMANA.................................................................................

1.3.3. O PAPEL DAS EMOÇÕES NA PERCEPÇÃO TEMPORAL HUMANA ...........53

1.3.4. O USO DA MÚSICA NO ESTUDO DA PERCEPÇÃO TEMPORAL

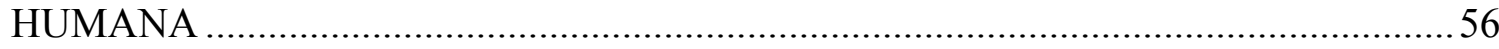

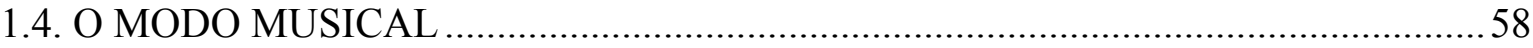

1.4.1. A CONTRIBUIÇÃO DOS MODOS GREGOS PARA O ESTUDO DAS

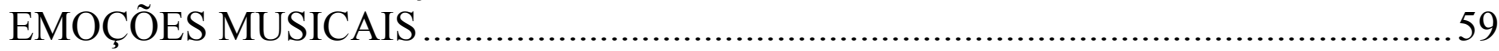

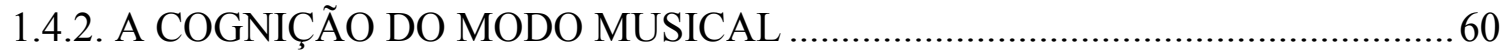

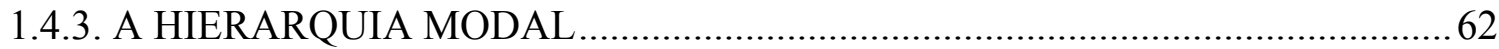

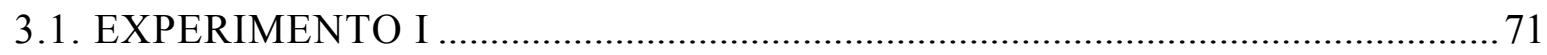

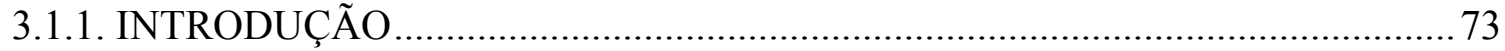

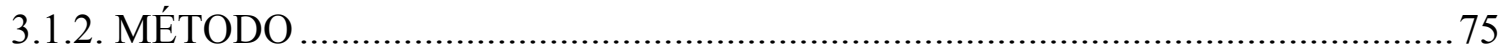




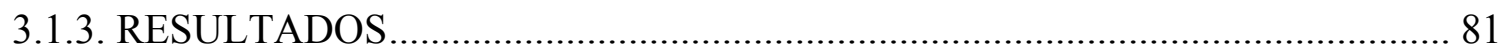

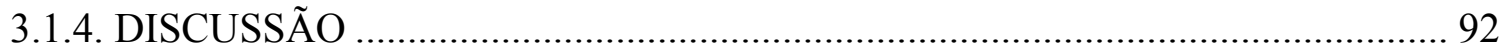

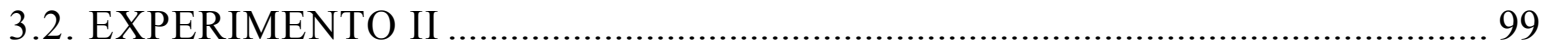

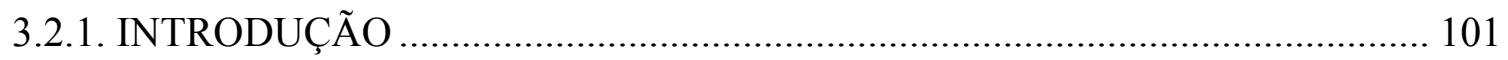

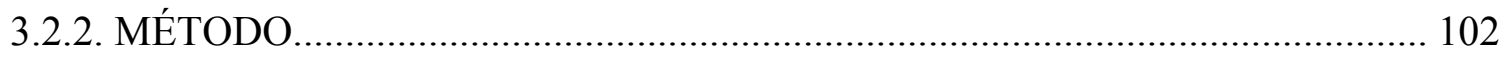

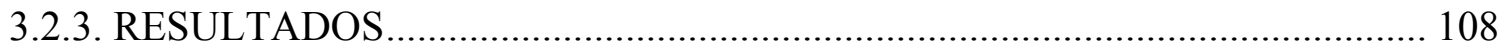

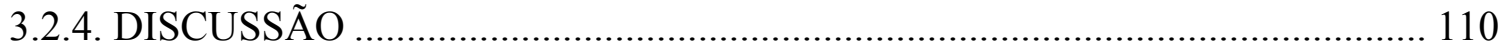

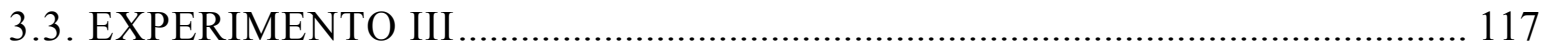

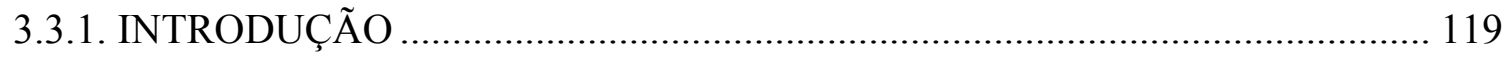

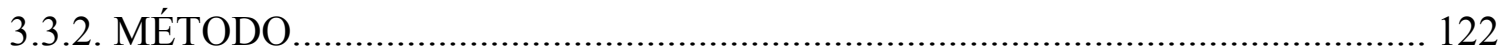

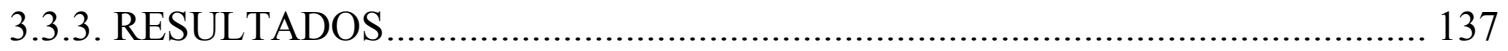

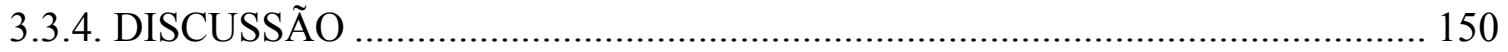

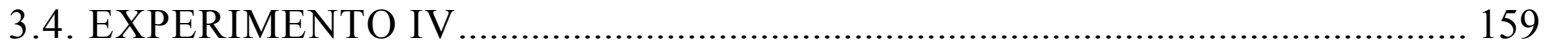

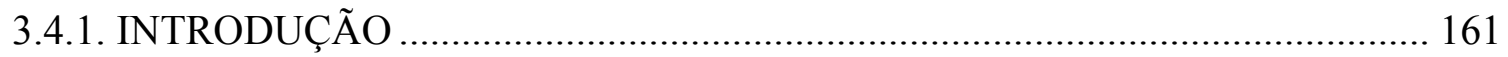

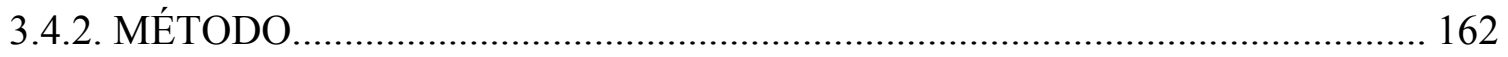

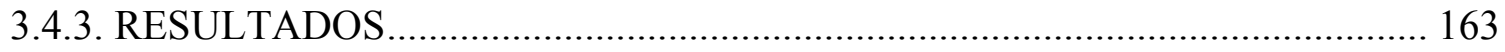

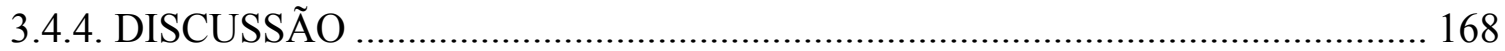

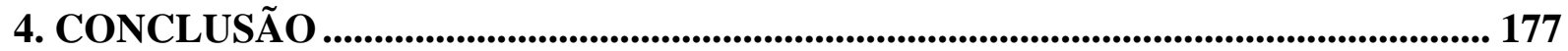

5. REFERÊNCIAS ....................................................................................................................... 189

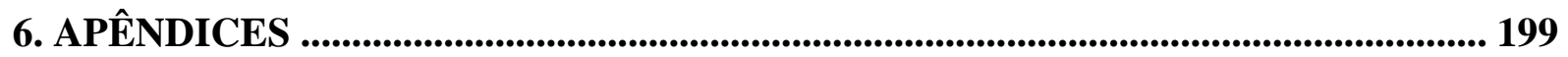

APÊNDICE A - Questionários experimentais ............................................................ 201

APÊNDICE B - Trechos musicais - Experimentos I e II .................................................. 219

APÊNDICE C - Partituras musicais - Experimentos III e IV …………………………….... 223

APÊNDICE D - CD - Trechos musicais (Experimentos I, II, III e IV) ………………..... 267 


\section{RESUMO}

RAMOS, Danilo. Fatores emocionais durante uma escuta musical afetam a percepção temporal de músicos e não músicos? 2008, 268 p. Tese (Doutorado). Faculdade de Filosofia, Ciências e Letras de Ribeirão Preto. Universidade de São Paulo, Ribeirão Preto, 2008 .

Esta pesquisa teve como objetivo verificar o papel das emoções desencadeadas pela música na percepção temporal de músicos e não músicos. Quatro experimentos foram realizados: no Experimento I, músicos e não músicos realizaram tarefas de associações emocionais a trechos musicais de 36 segundos de duração, pertencentes ao repertório erudito ocidental. A tarefa consistia em escutar cada trecho musical e associá-lo às categorias emocionais Alegria, Serenidade, Tristeza, Medo ou Raiva. Os resultados mostraram que a maioria dos trechos musicais desencadeou uma única emoção específica nos ouvintes; além disso, as associações emocionais dos músicos foram semelhantes às associações emocionais dos não músicos para a maioria dos trechos musicais apresentados. No Experimento II, músicos e não músicos realizaram tarefas de associação temporal aos trechos musicais mais representativos de cada emoção, utilizados no Experimento I. Assim, os trechos musicais eram apresentados e os participantes deveriam associar cada um deles a durações de 16, 18, 20, 22 ou 24 segundos. Os resultados mostraram que, para o grupo Músicos, os três trechos musicais associados à Tristeza foram subestimados em relação às suas durações reais; nenhuma outra categoria emocional apresentou mais do que um trecho musical sendo subestimado ou superestimado em relação a suas durações reais, para ambos os grupos. Pesquisas recentes em Psicologia da Música têm mostrado duas propriedades estruturais como sendo moduladoras da percepção de emoções específicas durante uma escuta musical: o modo (organização das notas dentro de uma escala musical) e o andamento (número de batidas por minuto). Assim, no Experimento III, músicos e não músicos realizaram tarefas de associações emocionais a composições musicais construídas em sete modos (Jônio, Dórico, Frígio, Lídio, Mixolídio, Eólio e Lócrio) e três andamentos (adágio, moderato e presto). O procedimento foi o mesmo utilizado no Experimento I. Os resultados mostraram que o modo musical modulou a valência afetiva desencadeada pelos trechos musicais: trechos musicais apresentados em modos maiores obtiveram índices positivos de valência afetiva e trechos musicais apresentados em modos menores obtiveram índices negativos de valência afetiva; além disso, o andamento musical modulou o arousal desencadeado pelos trechos musicais: quanto mais rápido o andamento do trecho musical, maiores os níveis de arousal desencadeados e vice-versa. No Experimento IV, músicos e não músicos realizaram tarefas de associação temporal aos trechos musicais modais utilizados no Experimento III. O procedimento foi o mesmo utilizado no Experimento II. Os resultados mostraram que manipulações, principalmente no arousal, afetaram a percepção temporal dos ouvintes: para ambos os grupos, foram encontradas subestimações temporais para trechos musicais desencadeadores de baixos índices de arousal; além disso, para o grupo Não Músicos, foram encontradas superestimações temporais para trechos musicais desencadeadores de altos índices de arousal. Estes resultados mostraram que, no caso dos músicos, a percepção temporal foi afetada por atmosferas emocionais relacionadas à Tristeza; no caso dos Não Músicos, a percepção temporal foi afetada por fatores relacionados ao nível do arousal dos eventos musicais apreciados. 


\begin{abstract}
RAMOS, Danilo. Do emotional factors during music listening tasks affect time perception of musicians and nonmusicians? 2008, 268 pages. Thesis ( $\mathrm{PhD}$ ). Faculty of Philosophy, Sciences and Letters of Ribeirão Preto. University of São Paulo, Ribeirão Preto, 2008.
\end{abstract}

This study aimed to verify the role of emotions triggered by music on time perception of musicians and nonmusicians. Four experiments were conducted: In Experiment I, musicians and nonmusicians performed emotional association tasks for musical excerpts of 36 seconds duration belonging to the Western classic repertoire. The tasks required to listen to each musical excerpt and to associate it with emotional categories: Joy, Serenity, Sadness, or Fear/Anger. The results showed that most musical excerpts triggered a specific single emotion in listeners; moreover, the emotional associations of musicians were similar to the emotional associations of nonmusicians for most musical excerpts presented. In Experiment II, musicians and nonmusicians performed temporal association tasks for the three most representative excerpts of each emotion used in Experiment I. Thus, the participants had to associate each of such musical excerpts with the following durations: 16, 18, 20, 22 or 24 seconds. The results showed that for the musicians, the three musical excerpts associated with Sadness were underestimated in relation to their real time; moreover, no other emotional category was associated with more than one musical excerpt whether being underestimated or overestimated, regarding their real time, for both groups. Recent researches in Psychology of Music have shown two structural properties as the modulators of specific emotions perceived during a music listening task: the mode (the organization of the notes in a musical scale) and tempo (the number of beats per minute). Thus, in Experiment III, musicians and nonmusicians carried out emotional association tasks with musical compositions constructed in seven modes (Ionian, Dorian, Phrygian, Lydian, Mixolydian, Aeolian, and Locrian) and three tempi (adagio, moderato, and presto). The procedure was the same used in Experiment I. The results showed that the musical mode modulated the affective valence triggered by the excerpts: musical excerpts based on major modes obtained positive affective valence indexes and musical excerpts based on minor modes obtained negative affective valence indexes; moreover, the musical tempo modulated the arousal triggered by the excerpts: the faster the tempo of the musical excerpts, the higher the arousal levels and vice versa, for both groups. In Experiment IV, musicians and nonmusicians performed temporal association tasks for those modal musical excerpts used in Experiment III. The procedure was the same used in Experiment II. The results showed that manipulations concerning arousal affected the time perception of the listeners: time underestimations due to low arousal excerpts were found for both groups; moreover, time underestimations due to high arousal excerpts were found only for nonmusicians. These results showed that in the case of musicians, time perception was affected by emotional atmospheres related to Sadness; in the case of nonmusicians, time perception was affected by factors related to the level of arousal of music events appreciated. 
1. INTRODUÇÃO 


\subsection{A NOVA ESTÉTICA EXPERIMENTAL}

Por que ouvimos música? Por que e como a música altera os nossos estados de ânimo? Por que pessoas que compartilham uma mesma casa, uma mesma rua, um mesmo bairro, uma mesma cidade ou região podem possuir gostos musicais tão distintos? Por que perdemos a noção do tempo quando estamos ouvindo música? Seria possível viver sem música? O estudo dos processos psicológicos envolvidos durante uma escuta musical tem procurado responder a questões como estas, encontradas com freqüência no quotidiano das pessoas de qualquer cultura. Motivado sobre a curiosidade em responder questões referentes aos processos psicológicos envolvidos em apreciações artísticas sonoras e visuais, Berlyne (1971, 1972, 1974) propôs uma teoria de apreciação estética, denominada A Nova Estética Experimental. Esta teoria está enraizada em tarefas relacionadas a respostas de sujeitos referentes à preferência estética, direcionadas a formas geométricas de diferentes tamanhos, nas quais o autor testou a noção de significado estético. Os resultados apontaram a idéia da associação da beleza à ausência de extremos. Assim, Berlyne (1974) caracterizou as pesquisas realizadas dentro de sua abordagem experimental de apreciação estética como possuidoras de uma ou mais das seguintes características:

1) as pesquisas de apreciação estética devem ser realizadas considerando a obra de arte como um padrão de estímulos, possuidora de propriedades colativas. Estas propriedades são "estruturais" ou "formais", cujas dimensões variam em léxicos opostos, como, por exemplo, não familiar / familiar, simples / complexo, esperado / surpreendente, ambíguo / claro, estável / instável;

2) questões motivacionais devem ser consideradas em qualquer pesquisa de apreciação estética; 
3) as pesquisas de apreciação estética devem ser realizadas considerando tanto os comportamentos expressos verbalmente, como também os comportamentos não-verbais;

4) ligações entre fenômenos estéticos e outros fenômenos psicológicos também devem ser consideradas, o que significa inferir que qualquer pesquisa, envolvendo atividades de apreciação artística, pode conduzir o investigador a resultados direcionados não só aos fenômenos estéticos, mas também a respostas sobre o comportamento humano em geral.

Berlyne (1974) ainda considera que estudos sobre estética experimental podem tomar duas direções: uma abordagem sintética, que consiste no isolamento de fatores artísticos específicos de uma obra de arte e uma abordagem analítica, que consiste no uso de obras de arte genuínas para o exercício da estética experimental. A definição do tipo de abordagem utilizada é determinada pelo próprio objeto do estudo a ser investigado. Uma vez definida, terá um papel saliente na apreciação, percepção e cognição da estética.

A teoria de Berlyne (1974) sugere que a preferência estética esteja relacionada ao potencial de arousal desencadeado no sujeito durante a sua apreciação estética. O potencial de arousal pode ser definido como estado de excitação fisiológica e está relacionado à quantidade de atividade produzida em áreas específicas do cérebro, como o sistema de ativação reticular. Assim, estímulos com um grau de potencial de arousal intermediário seriam preferidos pelos apreciadores em relação a estímulos com graus de arousal extremos. Portanto, segundo esta teoria, o grau de preferência do sujeito tende a diminuir gradualmente em direção aos extremos do potencial de arousal. Isso significa que a relação entre a preferência estética e o potencial de arousal de um determinado estímulo sugere um gráfíco em forma de U invertido, conforme a Figura 1 a seguir: 


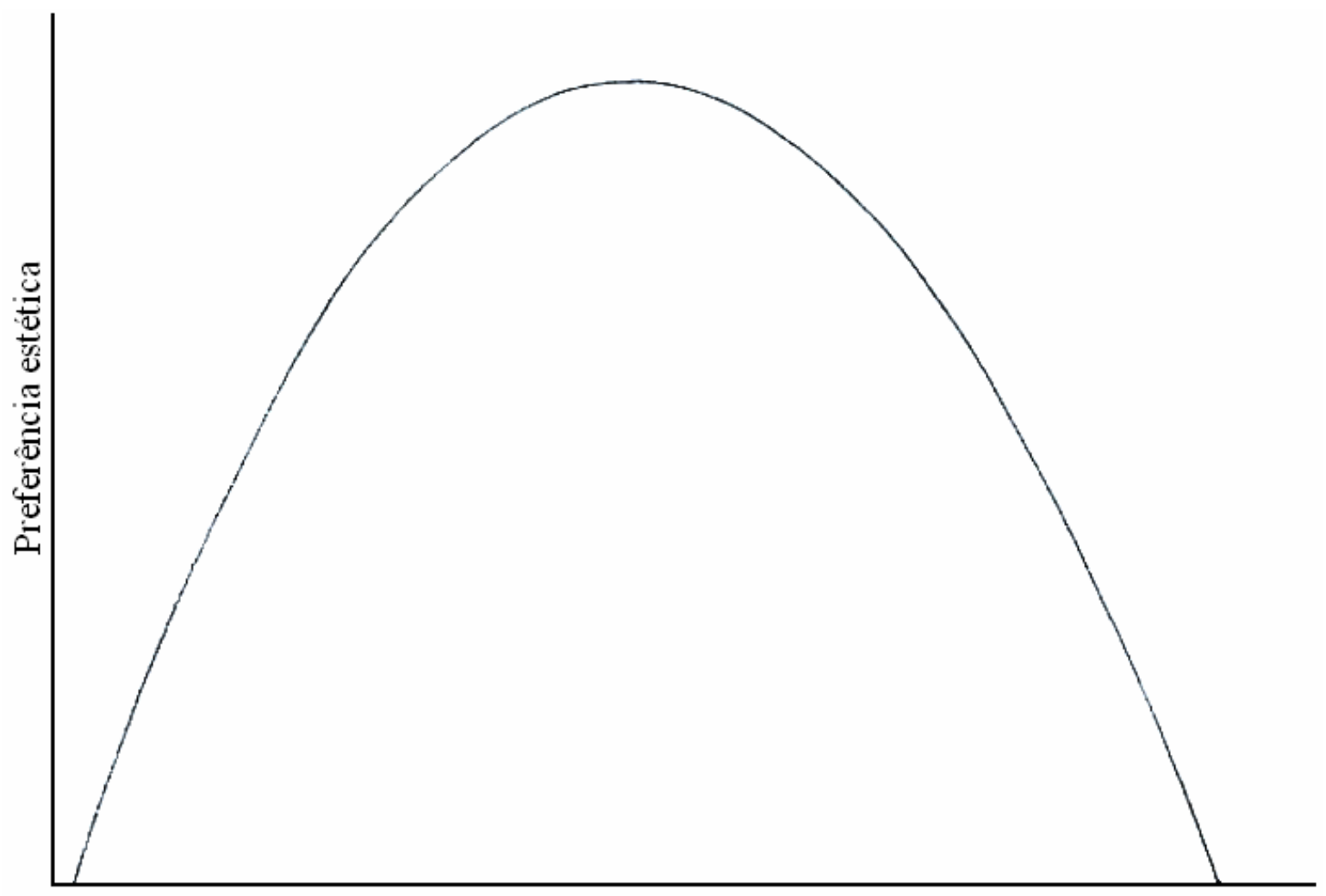

Potencial de arousal do estímulo

Figura 1. Relação entre preferência estética e potencial de arousal.

Berlyne (1974) relata que estímulos que apresentam um grau moderado de potencial de arousal são preferidos em relação aos estímulos que apresentam graus extremos de potencial de arousal porque, durante o processo de identificação do julgamento estético no cérebro humano, as fibras do sistema reticular caminham sobre os centros de prazer e desprazer. Com baixos níveis de arousal, o centro cerebral relacionado com o prazer é ativado e, portanto, a preferência estética caminha na mesma direção do arousal. No entanto, a partir de um pequeno aumento no nível de arousal, o centro cerebral relacionado ao desprazer também começa a ser ativado, e, assim, a relação entre preferência e arousal começa a se tornar inversa. Com altos níveis de arousal, a ativação do centro cerebral relacionado ao prazer começa a diminuir, enquanto a ativação do centro cerebral relacionado ao desprazer continua a crescer, e isso faz com que a preferência do indivíduo em relação à obra de arte apreciada diminua. 
Berlyne (1974) propôs que as variáveis relacionadas aos estímulos estéticos que apresentam graus moderados de arousal podem estar organizadas em três categorias: variáveis "psicofísicas", que são propriedades físicas intrínsecas dos estímulos, (como o andamento musical, por exemplo); variáveis “ecológicas”, que são as associações aprendidas entre os estímulos estéticos e outros eventos ou atividades de importância biológica (como a influência das emoções desencadeadas durante uma escuta musical sobre a percepção temporal humana, por exemplo); e variáveis "colativas" que são as propriedades que informam respostas subjetivas aos estímulos, como o seu grau de familiaridade ou complexidade. Berlyne (1971) ainda argumenta que as variáveis colativas são "as mais significativas dentre as três" (p. 69). Segundo o autor, o uso destas propriedades tem aparecido com mais freqüência em estudos experimentais de apreciação estética, principalmente por meio de experimentos que procuram manipular fatores como grau de familiaridade, grau de novidade e grau de complexidade dos eventos a serem apreciados.

Uma variável importante, envolvendo a música como estímulo-padrão em estudos realizados dentro desta nova abordagem experimental de apreciação estética, se refere à familiaridade do sujeito ao evento a ser apreciado. Esta familiaridade foi denominada “aculturação” por Hargreaves e Castell (1986) e está relacionada à idade do sujeito, uma vez que ele é exposto a uma gama maior de eventos musicais conforme vai ficando mais velho. Em um estudo realizado sobre a noção de familiaridade de sujeitos ocidentais com a música tonal ocidental, Hargreaves e Castell (1986) sugerem que os efeitos da familiaridade/aculturação interagem com a complexidade da música em questão. Segundo estes autores, conforme as pessoas se tornam mais familiares com um evento a ser apreciado, este evento se torna mais previsível e, conseqüentemente, menos subjetivamente complexo. A conseqüência disso é a diminuição do arousal direcionado a este evento. Desta forma, quanto mais uma pessoa for familiar a um estímulo, melhor ela o conhece. Assim, estímulos 
complexos e desencadeadores de altos níveis de arousal precisam tornar-se mais familiares para alcançar níveis moderados de arousal; ao contrário, estímulos simples, com níveis de arousal relativamente baixos, provavelmente desencadearão níveis de arousal moderados a partir de níveis de familiaridade muito menores (HEYDUCK, 1975).

A teoria de Berlyne (1974) também tem sido criticada na literatura principalmente pela tentativa de estabelecer relações entre os fenômenos estéticos e outros fenômenos psicológicos.

Konečni (1982) argumenta que a maioria dos estudos experimentais relacionados à preferência artística tem negligenciado o fato de que os processos de apreciação estética ocorrem normalmente em contextos sociais, emocionais e de aspirações cognitivas. Assim, estes processos não podem ser considerados como estando independentes dos contextos nos quais as pessoas vivenciam as suas apreciações artísticas no quotidiano. Konečni (1982) ainda pontua que, no caso da música, ela deve ser encarada como um evento vivenciado pelas pessoas em shoppings, restaurantes, enquanto realizam afazeres domésticos, e assim por diante e, portanto, torna-se necessário estabelecer se a teoria de Berlyne (embasada principalmente em contextos laboratoriais) pode ser aplicada para explicar preferências individuais em situações de escuta do quotidiano.

No entanto, a literatura aponta a teoria de Berlyne como sendo considerada bastante influente em pesquisas sobre apreciação artística até os dias atuais. Este estudo procurou investigar processos psicológicos referentes a tarefas de apreciação musical, no intuito de verificar a influência das emoções desencadeadas durante uma escuta musical na percepção temporal de músicos e não músicos, sob a ótica da nova estética experimental proposta por Berlyne (1974). 


\subsection{AS EMOÇÕES MUSICAIS}

Questões referentes à música e à emoção têm sido discutidas desde a antiguidade. No entanto, o estudo experimental do poder de evocação afetiva da música é recente. A publicação de estudos sistemáticos sobre música e emoção demorou a despertar o interesse dos cientistas, tanto aqueles de formação psicológica quanto os de formação musical. Assim, a maioria dos livros publicados sobre emoções, no século passado, não tinha sequer um capítulo que fizesse referência à música e, da mesma forma, a maioria dos livros publicados sobre Psicologia da Música não tinha sequer um capítulo que se referisse ao estudo das emoções (JUSLIN; SLOBODA, 2001).

Por que, então, o estudo das emoções musicais demorou tanto para evoluir, no curso da história da ciência? Juslin e Sloboda (2001) apontam quatro razões para este lento desenvolvimento:

1) a dificuldade de observação das reações evocadas por uma escuta musical em ambiente de laboratório. Um exemplo que ilustra esta dificuldade é a ausência de tecnologia que pudesse proporcionar uma escuta musical adequada, sem ruídos, de forma a permitir ao ouvinte a real percepção do evento musical, garantindo assim a precisão dos dados científicos;

2) a ênfase dada nos primeiros estudos em Psicologia da Música ao termo “cognição" (e não "emoção"), bem como a dificuldade de conceituação destes termos-chave, cujas definições causam confusão até mesmo entre os principais teóricos da área até os dias de hoje;

3) a complexidade metodológica destes estudos, uma vez que, durante muito tempo, os psicólogos comportamentais das décadas de 1940 e 1950 acreditavam que os 
estudos das emoções e outros processos mentais não deveriam ser categorizados como "científicos"; assim, muitos pesquisadores, ao apontarem as dificuldades de precisão metodológica, aliadas a estes estigmas, desistiam de continuar em seus estudos;

4) a forma particular e paradigmática como a maioria dos centros de excelência musical ouvia e falava sobre música, em que o fazer artístico, relacionado à aquisição da excelência no desempenho musical, sempre era considerado como o objetivo principal na formação dos músicos, enquanto o fazer científico era algo praticamente inexistente, denotando equivocadamente, assim, uma enorme distância entre ciência e arte. E esta realidade se reflete até os dias atuais.

Dos estudos experimentais sobre emoção e música realizados na primeira metade do século XX, principalmente por Hevner (1936) até os dias atuais, as questões sobre música e emoção têm gerado interesse tanto por leigos como por instrumentistas e pelos conhecedores de música. Muitos indivíduos, inclusive, têm procurado a prática de um instrumento musical por causa da possibilidade de expressão de suas emoções (JUSLIN; SLOBODA, 2001).

Alguns anos mais tarde, Meyer (1956) realizou um estudo que focou sistematicamente cada processo ocorrente na música, de momento a momento, considerando o resultado sonoro final como a soma das partes de todos estes momentos, argumentando que o significado central da música é encontrado na estrutura destes elementos e na forma musical, ao invés de estar nas associações a eventos não musicais. Especificamente, o autor considera o tipo de padrão e as referentes implicações sugeridas pela música (através da análise de padrões melódicos e rítmicos e organizações harmônicas), e como estas implicações são realizadas ou não realizadas no decorrer da seqüência de eventos. Suas teorias estão fundamentadas principalmente na Psicologia da Gestalt e na teoria da informação. 
A pesquisa de Meyer possibilitou que o objeto de estudo escolhido pela maioria dos pesquisadores, que a partir de então relacionaram música e emoção, fosse o ouvinte, algo que influenciou para sempre a pesquisa acerca da música e da emoção. Dentro deste grupo, os estudos objetivaram a mensuração das diferentes variáveis emocionais em músicos e não músicos, porque durante muito tempo acreditou-se que as emoções musicais fossem processadas da mesma forma que a linguagem (COSTA; FINE; BITTI, 2004; ROSS; CHOI; PURVES, 2007). Assim, as pesquisas sobre as emoções musicais e as emoções contidas na fala, nos gestos e nos comportamentos em geral passaram a ser também realizadas a partir da década de 1960.

Mais recentemente (e em evidência), outros pesquisadores se propuseram a mensurar as emoções humanas em tarefas relacionadas à percepção musical e ao desempenho e suas correlações com as atividades do cérebro humano. Estas pesquisas foram fundamentadas a partir da idéia de que a música pode oferecer uma única oportunidade de melhor entender como se organiza o cérebro humano (PERETZ; ZATORRE, 2003).

\subsubsection{A EXPRESSÃO “EMOÇÃO MUSICAL”}

Atualmente, há uma confusão conceitual relacionada à expressão “emoção musical”. Com o objetivo de valorizar o esforço realizado pelo acúmulo de pesquisas na área e promover um debate direcionado e frutífero, parece ser importante adotar certas distinções conceituais sobre emoção. Tais distinções parecem contribuir para que os pesquisadores se tornem mais sistemáticos, especificando, assim, seu foco de estudo. (JUSLIN; SLOBODA, 2001). 
Há muitas maneiras diferentes de definir emoção. No entanto, há um consenso estabelecido na literatura da área de que as emoções podem se referir a reações breves ou intensas dos indivíduos, que variam de acordo com o ambiente relacionado. Por esta abordagem, o conceito de emoção consiste em um número de componentes: avaliação cognitiva, sentimento subjetivo, arousal psicológico, expressão emocional, tendência de ação e regulação da emoção (JUSLIN; LAUKKA, 2004). Tais componentes estão explicados a seguir:

1) avaliação cognitiva: consiste em uma categorização emocional de determinado evento. Este componente emocional está mais relacionado com a percepção de uma emoção do que com o sentir esta emoção, de fato. Por exemplo: "você avalia uma situação como sendo perigosa";

2) sentimento subjetivo: consiste em sentir uma emoção desencadeada durante a apreciação de um evento. Este componente emocional está mais relacionado com o vivenciar uma emoção do que com simplesmente percebê-la. Por exemplo: "você sente medo";

3) arousal psicológico: este componente está relacionado com as manifestações fisiológicas no organismo diante de um evento. Por exemplo: “o seu coração começa a bater aceleradamente";

4) expressão emocional: consiste em tomadas de decisões (conscientes ou inconscientes) diante de uma determinada situação. Por exemplo: "você grita e sai correndo para pedir ajuda";

5) tendência de ação: este componente emocional está presente quando o indivíduo tem em sua mente uma possibilidade de ação diante de determinada situação, mas, 
não a concretiza. Por exemplo: "você está fortemente inclinado a fugir, mas não realiza o ato da fuga";

6) regulação da emoção: consiste em manifestações fisiológicas e cognitivas relacionadas aos momentos precedentes ao envolvimento emocional do indivíduo diante de determinada situação. Por exemplo: "você tenta se acalmar".

Os pesquisadores discordam com relação ao fato de que as emoções sejam mais bem conceituadas como categorias, dimensões, protótipos ou processos componentes. Assim, diferentes teorias relacionadas ao processamento da emoção humana (vide item 1.2.3. do presente trabalho) têm sido aderidas em estudos envolvendo música. Por tudo isso, é justo dizer que não há hoje, na literatura, um único paradigma teórico dominante em pesquisas sobre as emoções musicais e por isso, os cientistas costumam considerar as emoções musicais em diferentes focos e conceitos em seus estudos. No entanto, para que uma pesquisa seja realizada com sucesso, é necessário que os pesquisadores definam com clareza qual destes componentes será avaliado. A definição deste componente emocional depende única e exclusivamente dos objetivos do trabalho a ser realizado (JUSLIN; LAUKKA, 2004).

Em segundo lugar, existem diversas maneiras através das quais, a música pode expressar e evocar as emoções aos ouvintes. Por exemplo, algumas emoções podem ser ativadas principalmente por algumas características da própria estrutura musical (por exemplo, o modo, o andamento, o contorno melódico, etc.), enquanto outras podem ser emoções refletidas por associações pessoais. Portanto, o cientista deve observar que o que pode ser levado em conta para uma fonte específica de emoção pode não ser levado em conta para outra e que diferentes teorias podem ser requeridas para explicar cada fonte específica de emoção. Assim, diferentes fontes emocionais envolvem e são influenciadas por um número grande de variáveis causais em música, pela pessoa e pela situação (JØRGENSEN, 1988). Esta complexidade torna extremamente necessária a atenção dos pesquisadores na seleção de 
variáveis causais para seu objeto de estudo. Também, e, conseqüentemente, é importante que os pesquisadores estejam conscientes de que, após selecionar algumas variáveis causais, estão deixando outras de lado (JUSLIN; LAUKKA, 2004).

Em terceiro lugar, no estudo das emoções musicais, é importante que o pesquisador tenha clareza acerca da distinção entre expressão, percepção e indução de emoções. O pesquisador pode identificar a expressão de uma emoção no ouvinte por meio de alguns comportamentos precedentes ou durante uma escuta musical, como, por exemplo, um sorriso, uma lágrima, o franzir da testa, entre outros. O pesquisador pode identificar uma emoção percebida por meio de categorizações do próprio ouvinte durante ou após uma tarefa de escuta musical. Por exemplo: o ouvinte classifica uma música como sendo "triste". O pesquisador pode induzir uma emoção musical no ouvinte por meio de duas maneiras: a primeira consiste em apresentar aos ouvintes estímulos musicais previamente empregados em outros estudos sobre as emoções musicais; pelo fato de estes estímulos já terem sido testados em outros indivíduos de uma população semelhante (sujeitos ocidentais, por exemplo), podem então ser considerados como "estímulos musicais padrão, indutores de uma emoção específica", porque o pesquisador subentende que grandes são as chances de a mesma emoção ser identificada no decorrer da escuta em ambas as populações. A segunda maneira de um pesquisador induzir uma emoção musical no ouvinte consiste em se apropriar do conhecimento da história de vida do sujeito e apresentar-lhe estímulos musicais que relacionem associações emocionais obtidas no relato presente com situações emocionais de eventos passados. Neste caso, a música torna-se o elo entre o presente e o passado do indivíduo (JUSLIN; LAUKKA, 2004). Esta distinção entre expressão, percepção e indução das emoções torna-se importante por três razões: (1) porque os mecanismos podem ser diferenciados, dependendo do processo envolvido; (2) porque mensurar a expressão das emoções pode ser mais difícil do que mensurar a percepção das emoções, e os pesquisadores 
devem, portanto, adaptar os métodos de mensuração adequadamente para tal e (3) porque os tipos de emoções normalmente expressos e percebidos em música podem ser diferentes do conjunto de emoções normalmente induzido pela música (JUSLIN; LAUKKA, 2004).

Neste estudo, a emoção pode ser definida como avaliação cognitiva, no qual os participantes realizaram tarefas de escuta musical e associaram cada trecho musical ouvido a categorias emocionais distintas. Para tal, foi desenvolvida uma metodologia apropriada (vide Experimentos I e III do presente trabalho).

\subsubsection{METODOLOGIAS EMPREGADAS PARA MENSURAR AS EMOÇÕES} MUSICAIS

A grande questão que surge a respeito da percepção das emoções musicais durante uma escuta musical é em relação às diferenças individuais: cada indivíduo tem percepções e histórias de vida próprias e, portanto, cada um difere de outro na categorização emocional de um evento. Por isso, não há como dizer que as discordâncias emocionais no momento da escuta signifiquem que este indivíduo esteja ouvindo "errado". No entanto, uma tentativa de mensurar respostas emocionais específicas de uma mesma cultura envolve duas possibilidades que podem ser consideradas:

1) concordância entre os ouvintes: ocorre quando um número razoável de ouvintes associa uma mesma música a uma emoção específica. Por exemplo: 95\% dos participantes de determinado estudo associam os trinta primeiros segundos do Bolero de Ravel à emoção Alegria; portanto, para aquela determinada cultura, este trecho musical seria percebido como um trecho musical padrão desencadeador de alegria; 
2) nível de precisão entre as respostas do compositor e do ouvinte: ocorre quando um número razoável de ouvintes associa determinada música à mesma emoção pretendida pelo compositor. Por exemplo: se Ravel estivesse vivo, provavelmente perguntaríamos a ele qual seria a intenção emocional de seu Bolero. Se ele nos respondesse que os primeiros trinta segundos de seu Bolero tinham sido compostos no intuito de desencadear alegria nos ouvintes e se a maioria dos ouvintes de determinado estudo associasse este trecho musical à alegria, significaria que o Bolero de Ravel, para aquela determinada cultura, também seria percebido como um trecho musical padrão desencadeador de alegria.

A maioria dos estudos encontrados na literatura pertinente indica uma preferência metodológica para a concordância entre os ouvintes, por requerer do pesquisador um menor esforço para a coleta de seus dados (JUSLIN; LAUKKA, 2004).

Há diversas metodologias adotadas pelos estudos prévios sobre a mensuração da percepção das emoções durante uma experiência de escuta musical. Estas metodologias podem ser divididas em três grandes áreas, que, por sua vez, podem ainda ter suas ramificações:

1) Medidas comportamentais: consistem na análise sistemática das manifestações comportamentais que o sujeito pode expressar diante de um evento musical. Estas manifestações podem ser medidas por meio da exteriorização de padrões comportamentais diante da escuta (por exemplo, expressões faciais, manifestação ritmocorporal, exteriorização de estados de ânimo como o sono, etc.). Uma pesquisa envolvendo medidas comportamentais pode ser realizada em dois tipos de ambientes: em laboratório ou fora dele. Em ambos os casos, o pesquisador pode desenvolver seu estudo por meio de uma observação participante (interagindo com o sujeito, anotando as suas observações e até mesmo induzindo o sujeito a um padrão comportamental, se for o caso) ou através de uma 
observação não participante. Neste último caso, faz-se necessária toda uma infra-estrutura adequada na montagem do ambiente experimental (um ambiente onde o sujeito possa ser observado sem que veja ou reconheça a presença do experimentador). Por isso, a realização de uma observação não participante se torna muito difícil fora do ambiente laboratorial. Com o avanço da tecnologia e apesar de não ser a metodologia mais utilizada pelos pesquisadores na história do estudo das emoções musicais, as pesquisas envolvendo uma observação não participante (na qual o pesquisador observa à distância o comportamento do sujeito) têm sido desenvolvidas, de forma geral. Estas pesquisas têm dado ênfase a dois tipos de comportamento: o tempo de exploração, em que o sujeito tem o poder de "explorar" um estímulo musical, ouvindo, assim, a peça a ser analisada quantas vezes ele julgar necessário, cabendo ao pesquisador gravar a duração da exposição de cada estímulo, para depois realizar uma análise descritiva destes dados e a escolha exploratória, em que o sujeito é colocado diante de dois ou mais estímulos musicais, devendo escolher entre ouvir um ou outro (provavelmente aquele que mais lhe agrade ou cause curiosidade). A escolha pode ser cega, isto é, sem que o sujeito saiba o conteúdo musical dos estímulos ou consciente (em que o sujeito é avisado sobre o tipo de evento musical que lhe vai ser exposto). O que vai determinar a escolha de uma determinada metodologia é o próprio objeto que vai ser estudado.

2) Medidas cognitivas - os experimentos realizados utilizando as medidas cognitivas consistem na análise sistemática dos relatos verbais fornecidos pelos sujeitos durante ou após a escuta de um evento musical. Estas manifestações podem ser medidas através de:

- testes de escolha forçada: trata-se de um teste em que o sujeito escolhe apenas uma categoria emocional, contida em uma pequena lista de categorias de emoções; 
- lista de adjetivos: trata-se de uma lista de predicados, em que o sujeito escolhe um número adequado de adjetivos para identificar as emoções presentes no evento musical;

- taxas emocionais: trata-se de escalas de diferencial semântico, que geralmente contêm de 3 a 10 caselas, em que o sujeito atribui uma nota correspondente ao grau percebido daquela emoção específica na hora da escuta, por exemplo, o número 1 significando "pouca alegria" e 10 significando "muita alegria". A principal dificuldade encontrada neste tipo de metodologia é a de estabelecer uma mensuração eficaz dos parâmetros emocionais ligados à música: normalmente, as escalas bipolares (com a emoção Alegria em uma ponta e Tristeza na outra ponta, por exemplo) têm sido utilizadas de forma inadequada nos estudos, devido ao fato de que nem sempre uma propriedade significa o oposto de outra (JUSLIN; LAUKKA, 2003; DALLA BELLA et al., 2001a; JUSLIN; SLOBODA, 2001; LARSEN; MCGRAW; CACIOPPO, 2001; KRUMHANSL, 1997). A literatura recente tem sugerido o uso de escalas unipolares para o estudo das emoções musicais. Neste tipo de escala, apenas uma emoção é considerada (Alegria, por exemplo) e o indivíduo responde, geralmente com atribuições de 0 a 10, a quantidade de Alegria que o evento musical sugere;

- descrições livres: trata-se de uma metodologia em que o sujeito descreve o estímulo musical utilizando as palavras que vierem à sua mente.

3) Medidas psicofisiológicas: consistem na análise sistemática das alterações fisiológicas dos sujeitos através do uso de tecnologia apropriada durante ou após uma escuta musical. A maioria dos estudos utilizando estas medidas tem procurado mensurar o batimento cardíaco, a condutância de pele ou mesmo as imagens cerebrais do sujeito no momento da escuta musical, através de aparelhos como eletroencefalograma. Neste tipo de experimento, é indispensável que o pesquisador conte com a ajuda de profissionais como médicos neurologistas, neurocientistas e técnicos operacionais. Cabe, portanto, ao pesquisador colher informações destes profissionais e analisá-las, atribuindo um significado emocional a elas. A 
grande questão que envolve a prática da análise de medidas fisiológicas é verificar as possibilidades de benefícios que a música pode proporcionar ao desenvolvimento sensorial, cognitivo e motor do homem. Grande parte dos estudos tem procurado analisar as diferenças cerebrais entre músicos e não músicos, com o propósito de identificar as áreas de atuação da música no cérebro humano, estabelecendo, assim, as relações existentes entre os mecanismos utilizados na linguagem e na música. As futuras descobertas destes estudos serão de extrema importância para diversos objetos de estudo, como aptidão, educação e desempenho musicais (PERETZ; ZATORRE, 2003).

Independente do tipo de medida envolvida, há um consenso na literatura referente à percepção das emoções musicais, indicando que, de um modo geral, as respostas emocionais de ouvintes de uma mesma cultura a um mesmo trecho musical são semelhantes. Assim, um grande número de ouvintes pode fornecer dados indicando um evento musical como tendo uma "emoção positiva". No entanto, a consistência das respostas é menor, se consideramos algumas nuances dentro da categoria "emoção positiva". Por exemplo: se considerarmos as emoções Serenidade, Amor, Ternura, Alegria como sendo positivas, as respostas referentes a estas emoções sobre um mesmo trecho musical, provavelmente, serão bastante divergentes. Por tudo isso, ainda não se pode afirmar, com clareza, que a música pode comunicar uma emoção específica aos ouvintes (JUSLIN; LAUKKA, 2004).

Além de medidas comportamentais, cognitivas e psicofisiológicas, as emoções musicais também podem ser mensuradas em função das duas dimensões envolvidas em qualquer escuta musical, o potencial de arousal e a valência afetiva. A valência afetiva (ou valor hedônico) é mensurada a partir da premissa de que toda música carrega em si um valor afetivo, que pode variar de pessoa para pessoa; podemos ficar em um determinado estado emocional durante uma escuta musical, dependendo de nossas diferenças individuais, oriundas de nossos diferentes valores culturais (valores adquiridos a partir do meio em que 
vivemos) e biológicos (valores inatos, que se referem ao conteúdo genético transmitido de geração a geração). O potencial de arousal (ou estado de excitação fisiológica) é mensurado a partir da premissa de que toda escuta musical provoca no sujeito uma reação, que é uma espécie de estado de pré-ativação interna, em que mecanismos neurais e cognitivos são ativados, levando o sujeito a prestar atenção à música que está sendo executada. O potencial de arousal chega a provocar até mesmo reações fisiológicas nos sujeitos, como bater o pé ou as mãos para imitar o acompanhamento da música, dançar, entre outros comportamentos.

Além do tipo de medida envolvida, as pesquisas que mensuram as emoções musicais também revelam que a percepção de uma emoção musical depende de vários fatores, não somente das propriedades estruturais específicas da música apreciada, mas também da forma da resposta, do procedimento da pesquisa, do tipo de sujeito analisado, etc. A maioria das pesquisas sobre a percepção das emoções mostrou apenas diferenças sutis em relação à idade, ao gênero e à habilidade musical do sujeito.

Considerando a expertise musical, definida como a aquisição progressiva do estudo sistematizado de algum instrumento musical (GALVÃO, 2006), aparentemente, os músicos percebem uma emoção de forma parecida com os não músicos. Em um estudo realizado por Bigand et al. (2005), músicos e não músicos ouviram 27 trechos de composições eruditas do repertório ocidental selecionadas para desencadear emoções de base - Alegria, Tristeza, Raiva ou Serenidade - e também emoções mais sutis. A tarefa experimental consistia em reagrupar os trechos musicais característicos de uma mesma emoção, definindo assim categorias emocionais sem recorrer à linguagem verbal, no intuito de abrir mão de um léxico emocional que se sabe variável em função do nível de conhecimento musical e das aptidões verbais de cada um. Duas semanas depois da realização do experimento, os mesmos participantes refizeram a tarefa com os mesmos trechos musicais. Os resultados indicaram que as respostas emocionais às músicas apresentadas foram semelhantes entre os músicos e os não 
músicos. As principais emoções categorizadas foram: Alegria, Tristeza, Serenidade, Medo e Raiva. No entanto, apesar das respostas emocionais terem sido semelhantes, houve maior homogeneidade de respostas dos músicos para cada música apresentada em relação aos não músicos.

\subsubsection{TEORIAS E MODELOS SOBRE A PERCEPÇÃO DAS EMOÇÕES MUSICAIS}

As principais teorias e modelos encontrados na literatura que tentam explicar as emoções desencadeadas durante a experiência de uma escuta musical procuraram responder a uma única pergunta: “a música pode evocar emoções específicas nos ouvintes?”.

Langer (1957), em seu tratado sobre música e emoção, desenvolveu a idéia de que as formas do sentimento humano podem ser muito mais congruentes com as formas musicais do que com as formas da linguagem. Esta idéia foi contra as teorias que sustentavam a idéia de pensar o caráter emotivo da música como uma forma isolada, apenas como resultado de gestos musicais (mímicas) das expressões das emoções vocais humanas, desconsiderando o caráter emotivo do próprio evento musical em si. No entanto, esta teoria não relacionou a questão referente à percepção das emoções contidas no evento musical com o entendimento dos idiomas musicais específicos. Tampouco explorou a hipótese de que propriedades elementares contidas na música, como mudanças na altura ou no andamento, poderiam mapear diretamente o teor dos códigos culturais específicos e as tradições musicais de cada indivíduo. Langer rejeitou a idéia de que a música possa representar emoções específicas; argumentou ainda que a música imita somente a forma da emoção e não o conteúdo. Por exemplo: a música pode desencadear no ouvinte um alto conteúdo emocional, 
mas ser categorizada como sendo igualmente alegre e triste ao mesmo tempo. Esta visão sugeriu que a representação da emoção em música é inerentemente indefinida.

Mandler (1984) propôs uma teoria sobre a emoção musical baseada nos primeiros trabalhos de Meyer (1956) acerca da expectativa musical. Esta teoria levou em conta uma conexão entre as qualidades emocionais da música e os valores adaptativos das reações emocionais. Especificamente, a violação de nossas expectativas nos traria um arousal biológico, que funcionaria como um sinal de alerta. Este sinal de alerta, então, nos estimularia a uma interpretação do evento musical, que, quando combinado com o arousal biológico, seria sentido como emoção. Assim como a teoria de Langer (1957), esta teoria sugeriu que a música não poderia evocar emoções específicas nos ouvintes: as interpretações emocionais seriam frutos de um arousal biológico originado pela violação das expectativas musicais. Entretanto, este arousal biológico não poderia ser essencialmente medido. Portanto, segundo Mandler (1984), as qualidades emocionais não poderiam ser diretamente inferidas através das propriedades de arousal.

A teoria de Cooke (1959) se propôs a analisar os elementos da expressão musical, estabelecendo um léxico destes elementos em termos de emoções específicas que eles são capazes de desencadear. O autor testou esta teoria tomando como material a música tonal ocidental antiga, servindo-se de composições que datam a partir de 1400 d.C. Em sua análise, Cooke identificou padrões musicais que eram comumente usados para expressão das emoções, desde a música antiga até a música do século XX. Ao analisar estes motivos melódicos através de seus componentes intervalares, mostrou que cada "termo básico" tem um caráter particular emotivo, como por exemplo, os graus V-I-II e III da escala menor, que, quando tocados sucessivamente, indicam um forte sentimento de tragédia. Entretanto, Cooke não conseguiu substanciar sua teoria empiricamente. Mais tarde, Gabriel (1978) realizou um experimento em que seus ouvintes deveriam classificar as qualidades emotivas dos "termos 
básicos" propostos por Cooke (1959). Embora a hipótese da teoria de Cooke fosse a de que a música poderia evocar emoções específicas nos ouvintes, não foram encontrados padrões significativos de concordância entre os julgamentos dos ouvintes de Gabriel (1978) com as descrições dos conteúdos emocionais evocados pelos “termos básicos” de Cooke (1959).

A teoria de Kivy (1980) também respondeu positivamente à questão de a música evocar ou não emoções específicas nos ouvintes. Kivy também acreditou que certos padrões melódicos estariam convencionalmente associados a predicados expressivos especificáveis, como "é triste", "me irrita”, "me dá alegria”. Kivy propôs uma distinção entre dois tipos de pistas emocionais em música: "contorno" e "convenção". Em sua discussão sobre "contorno", o autor identificou elementos da música clássica ocidental que têm uma conexão natural com a vida emotiva (emoções expressas por pronúncia vocal, postura, gestos e movimentos corporais), como contorno melódico, andamento e ritmo. Em sua discussão sobre "convenção", estes elementos foram também caracterizados. Dessa forma, segundo esta teoria, todas as associações convencionais entre a música e a emoção seguramente seriam derivadas das convenções naturais entre a música e a "vida emotiva". Assim, as conexões naturais são tanto culturais quanto específicas, sendo que a música de uma cultura pode refletir somente a vida emotiva daquela cultura. Kivy ainda argumenta que os ouvintes de uma determinada cultura não seriam capazes de perceber a música oriunda de um sistema musical não familiar ${ }^{1}$ como música por si só, mas sim como uma seqüência de sons não musicais; segundo o autor, se um indivíduo escutar dezenas de músicas de outra cultura que não a sua, estas provavelmente soam como algo exótico; logo, este indivíduo seria incapaz de discriminar emoções específicas entre estes estímulos.

\footnotetext{
${ }^{1}$ Um sistema musical não familiar pode ser definido como um conjunto de elementos musicais (melódicos e harmônicos) não encontráveis comumente em determinada cultura. Por exemplo: a escala pentatônica, escala de cinco notas, encontrável comumente na China, na Indonésia e na África, pode ser considerada como parte de um sistema musical não familiar à cultura do Ocidente, uma vez que o modelo escalar da tradição musical dessa cultura está enraizado na escala diatônica, formada por sete notas musicais (WISNIK, 2004).
} 
Apesar de concordar com a teoria de Kivy a respeito da existência de emoções específicas evocadas pela música, Balkwill e Thompson (1999) divergiram no sentido oposto com relação às convenções culturais do indivíduo. Os achados destes autores ilustraram que os ouvintes adaptam suas habilidades de interpretar estilos musicais não familiares. No entanto, estes autores acautelaram o leitor para o seguinte enunciado: "quanto maior o número de pistas (culturais ou psicofísicas) presentes na música, maior a expressão das emoções" (BALKWILL; THOMPSON, 1999). Assim, para estes autores, a expressão da emoção na música de uma dada cultura parece ser mais saliente aos ouvintes desta mesma cultura, devido ao entendimento compartilhado da representação convencional da emoção dentro daquele sistema (tonal ou não tonal); quando as pistas culturais não estão presentes, o ouvinte deve prestar mais atenção às pistas perceptuais básicas, como o andamento e a complexidade. Estas pistas levam os ouvintes a um maior entendimento geral da emoção pretendida. Assim, é possível argumentar que a associação entre as dimensões psicofísicas da música com a percepção das emoções seja também o resultado da aculturação e possa diferir entre culturas. A teoria de Balkwin e Thompson (1999) encontrou dois achados: primeiro, os ouvintes aculturados a um sistema tonal podem perceber precisamente a emoção pretendida na música de um sistema musical não familiar; segundo, os ouvintes se apropriam de dimensões psicofísicas da música como pistas para identificar musicalmente as emoções expressas.

Juslin e Laukka (2004) elaboraram um modelo denominado Expanded Lens Model com o objetivo de explicar a variância das respostas emocionais de ouvintes ocidentais referentes à emoção Alegria em relação a eventos musicais. Este modelo, uma versão atualizada do Brunswilk’s Lens Model, desenvolvido por Juslin (1995, 2000), propôs uma análise interativa entre as pistas acústicas fornecidas aos ouvintes em primeira instância pelo compositor e em segunda instância, pelo intérprete. Assim, o grau de alegria em uma música seria percebido a partir de um processo em que, em um primeiro momento, o compositor cria 
a obra musical. Neste momento, já estariam embutidas na própria obra, algumas pistas acústicas que seriam executadas intuitivamente, tanto pelo compositor quanto pelo intérprete da obra (o modo, a tonalidade, o contorno melódico e o ritmo). Num segundo momento, durante a execução da obra pelo intérprete, apareceriam outras pistas acústicas que podem não ser executadas da mesma forma, conforme concebidas pelo compositor e pelo intérprete (o andamento, a altura do som, a articulação, o timbre). Esta interação entre as pistas acústicas fornecidas pelo compositor (de acordo com os padrões de estilo da época de composição) e as pistas acústicas executadas pelo intérprete (conforme os padrões de estilo da época da execução) é que levariam o indivíduo a julgar o grau de alegria da música. Portanto, segundo este modelo, uma mesma peça musical poderia conter níveis diferentes de alegria, dependendo da forma em que foi executada (gravada ou ao vivo, pelo mesmo intérprete ou por intérpretes diferentes, por instrumentos diferentes, etc.). Segundo os autores, este modelo conseguiu explicar cerca de $90 \%$ da variância em julgamentos de alegria por diferentes ouvintes, sustentando a idéia de que diferenças individuais existem (cada indivíduo percebe e categoriza as emoções de sua própria maneira), porém, algumas pistas acústicas presentes na música podem fornecer tendências comuns para respostas emocionais referentes à emoção Alegria. No entanto, por utilizar somente exemplos musicais referentes à música ocidental e não escritos, o modelo de Juslin e Laukka (2004) pode ser útil apenas para a música tonal (e não para a música não tonal ou não notada).

Em uma meta-análise sobre a precisão da comunicação, Juslin e Laukka (2004) encontraram evidências relacionadas ao processo de comunicação entre o intérprete e o ouvinte, mostrando uma operação em termos de rótulos de categorias emocionais. Tais evidências foram encontradas em estudos que utilizaram a concordância entre os ouvintes como variável dependente. A partir destes dados, estes autores demonstraram que músicos profissionais foram capazes de comunicar cinco emoções (Alegria, Raiva, Tristeza, Medo e 
Amor/Ternura) aos ouvintes com um grau de precisão aproximadamente igual ao grau de precisão de suas expressões vocais e faciais durante as suas apresentações, demonstrando também que seria difícil realizar uma distinção fina entre estas categorias sem um contexto adicional proveniente da prosódia musical (letra), expressões faciais e impressões visuais. (JUSLIN; LAUKKA, 2003).

O modelo circumplexo de Russel $(1979,1980)$ também tem contribuído para o entendimento dos processos psicológicos relacionados às respostas emocionais à música. A ilustração deste modelo consiste de uma estrutura bidimensional, circular, baseada em dimensões bipolares de arousal (estado de excitação fisiológica) e valência afetiva (agradabilidade), o que dá origem a quatro quadrantes, cada um dos quais representado por categorias emocionais semelhantes. Por exemplo: em um quadrante no qual o arousal é alto e a valência afetiva é positiva, encontram-se categorias emocionais relacionadas à alegria e à excitação; em um quadrante no qual o arousal é alto, mas a valência afetiva é negativa, encontram-se categorias emocionais relacionadas ao medo e à raiva; em um quadrante no qual o arousal é baixo, mas a valência afetiva é positiva, encontram-se categorias emocionais relacionadas ao relaxamento e à serenidade; em um quadrante no qual o arousal é baixo e a valência afetiva é negativa, encontram-se categorias emocionais relacionadas à tristeza e à sonolência. Este modelo tem sido criticado por não capturar diferenciações mais sutis dos processos emocionais, na medida em que prioriza a categorização emocional, negligenciando uma compreensão mais aprofundada sobre o significado dos léxicos emocionais dentro de cada cultura (LARSEN; DIENER, 1992). No entanto, o modelo pode ser bastante útil para desenvolver estudos empíricos sobre as respostas emocionais à música, porque fornece uma maneira eficaz de organizar as emoções em termos do afeto (agradável ou desagradável) e das reações fisiológicas (excitação elevada ou baixa), e, além disso, especifica uma maneira de 
selecionar adjetivos a serem utilizados como medidas de emoção na investigação (LARSEN; DIENER, 1992; JUSLIN; SLOBODA, 2001).

\subsubsection{O USO DO MODO E DO ANDAMENTO MUSICAL EM PESQUISAS SOBRE AS EMOÇÕES MUSICAIS}

O estudo das emoções musicais requer um material que torne possível o controle e um pequeno número de fatores musicais supostamente importantes na expressão e na percepção dessas emoções. Segundo uma das principais teorias, o que determina o caráter emocional da música são expectativas musicais determinadas pelos momentos de tensão e relaxamento que se sucedem no decorrer de uma música (MANDLER, 1984). Baseado nesta teoria, muitos pesquisadores têm estudado sistematicamente quais são estes elementos estruturais determinantes da expressão das emoções. O sistema musical utilizado nos estudos nesta área geralmente tem sido a música erudita ocidental. Assim, os primeiros estudos desenvolvidos por Hevner (1936) mostraram que o modo e o andamento são índices essenciais para determinar se uma melodia é triste ou alegre. O modo pode ser definido como uma série de notas sucessivas organizadas segundo um padrão de intervalos musicais definido, diferindo de um modo a outro - menor e maior; por exemplo: o modo maior é construído a partir da organização dos tons e semitons de sua escala (uma escala maior tem a configuração “tom, tom, semitom, tom, tom, tom, semitom”; já o modo menor é construído a partir da organização "tom, semitom, tom, tom, semitom, tom, tom). O andamento pode ser definido como o grau de velocidade que se imprime à execução de um trecho musical. Mais especificamente, andamentos rápidos tendem a evocar músicas alegres e andamentos lentos tendem a evocar músicas tristes (GAGNON; PERETZ, 2003). Similarmente, o modo maior 
está associado à alegria e o modo menor está associado à tristeza (DALLA BELLA et al., 2001b).

Existem evidências de que a manipulação no andamento e no modo de uma música afeta os julgamentos de alegria e tristeza em adultos. Em crianças, a sensibilidade da percepção de manipulações no andamento aparece antes da sensibilidade da percepção de manipulações ao modo (DALLA BELLA et al., 2001b). Para sustentar essa hipótese, foi realizado um experimento que procurou investigar se a habilidade de detectar a informação emocional através da música aparece cedo no desenvolvimento infantil ou demanda um longo aprendizado. Nos experimentos de Dalla Bella et al. (2001b), crianças de 3 a 8 anos de idade ouviam trechos de música em quatro condições experimentais: em duas condições isoladas, fazia-se variar o modo ou o andamento de melodias simples e, em duas outras, combinavamse os dois parâmetros, um para evocar uma mesma emoção (um andamento rápido e um modo maior contribuem ambos para a expressão da alegria - condição convergente) e outro para evocar emoções diferentes (um andamento rápido e um modo menor - condição convergente). Através de uma escala de 10 pontos, as crianças selecionadas indicavam se consideravam o trecho triste ou alegre, e as respostas seriam comparadas às dos adultos (usavam-se desenhos de carinhas sorridentes ou tristes, e a criança deveria indicar qual era adequado para cada trecho). Os resultados sugeriram que as reações das crianças entre 6 e 8 anos, como a dos adultos, são influenciadas por fatores de modo e andamento. Nas crianças de 5 anos, os julgamentos dependeram apenas do andamento. Em crianças de 3 e 4 anos, nenhum dos parâmetros pareceu guiar as respostas. Os resultados mostraram que em condição de manipulação isolada, os dois fatores de modo e de andamento facilitaram o reconhecimento da emoção. No entanto, quando os dois parâmetros foram combinados e divergentes, os ouvintes utilizaram prioritariamente o andamento para fundamentar seu julgamento emocional das melodias. Este estudo mostrou, portanto, que o andamento foi uma informação mais fácil 
de processar do que o modo (que subentende o processamento de informações mais abstratas, como, por exemplo, os intervalos de altura). Concluiu-se, portanto, que o andamento representou um índice perceptivo mais rapidamente adquirido para processar as informações emocionais veiculadas pela música (GAGNON; PERETZ, 2003).

Khalfa et al. (2002) procuraram mensurar as emoções musicais por meio de medidas psicofisiológicas. Para tal, realizaram um experimento registrando reações fisiológicas de sujeitos humanos durante uma escuta musical. Através da mensuração de respostas galvânicas da pele, estes pesquisadores encontraram dados que comprovam que em reações emocionais (alegria, tristeza e medo, por exemplo), o sistema nervoso central reage com aceleração dos batimentos cardíacos ou aumento da transpiração. Estes pesquisadores descobriram também, que para os trechos musicais que desencadeavam medo e alegria, essa reação era mais forte que para trechos que exprimiam tristeza ou serenidade. Assim, andamentos rápidos e dinâmicas musicais fortes provocaram o aumento de arousal (excitação fisiológica), o que não ocorreu com trechos lentos e menos dinâmicos. Além disso, os dados obtidos neste estudo revelaram que as respostas emocionais à música foram, no geral, diferentes das respostas cutâneas, mostrando que nem sempre a categorização emocional do sujeito durante uma escuta musical se reflete em reações fisiológicas. Pode-se afirmar, portanto, que a música é capaz de exercer grande poder sobre o comportamento humano e que normalmente, durante a escuta musical, o ouvinte não está consciente do efeito que a música exerce sobre ele.

No experimento realizado por Bigand et al. (2005), em que músicos e não músicos reagrupavam os trechos musicais característicos de uma mesma emoção, uma análise matemática dos resultados conhecida como "escala multidimensional" fez aparecer reagrupamentos que evidenciam parâmetros de modo e andamento implicados na expressão emocional dos ouvintes. Assim, diferentes trechos foram reagrupados em quatro grandes 
categorias, correspondendo às seguintes combinações: modos menores e andamentos lentos foram associados a uma valência afetiva negativa e uma dinâmica fraca (calmante) ao trecho, percebido como "triste"; modos menores e dinâmicas estimulantes evocaram sentimento de "raiva" ou de "medo"; ao contrário, modos maiores e andamentos estimulantes foram percebidos como sendo "alegres" e músicas tocadas em modos maiores e andamentos lentos foram associadas à emoção Serenidade.

Ainda referente a este mesmo estudo, uma análise posterior foi feita, no intuito de descrever a organização mental das representações emocionais desencadeadas pela música nesse grupo. Para isso, Bigand et al. (2005) mensuraram as dimensões psicológicas de arousal e valência afetiva das respostas emocionais dos ouvintes. O exame dos reagrupamentos emocionais mostrou que os ouvintes reconhecem as grandes categorias de emoção - alegria, tristeza, raiva, serenidade - e percebem diferenças emocionais muitos sutis em trechos de 30 segundos de duração. Além disso, foi constatado que os trechos foram reagrupados segundo seu caráter positivo (conferido pelo modo maior) ou negativo (conferido pelo modo menor). A essa reação acrescentam-se as variações do arousal. Os resultados indicaram que os momentos de tensão musical provocaram uma aceleração do ritmo cardíaco dos ouvintes.

Pode-se concluir, com base nos estudos descritos acima, um ponto essencial para a compreensão dos processos cognitivos envolvidos durante a escuta musical referentes à música ocidental: as emoções musicais são resultantes de processos cognitivos específicos, ou seja, dependem da cognição dos elementos da estrutura musical de uma obra. Assim, com relação à música executada nas culturas ocidentais, estas descobertas recentes negam a hipótese de que a música evoque emoções de acordo com a história pessoal de cada um. 


\subsection{A PERCEPÇÃO TEMPORAL HUMANA}

O homem é um ser espectador de um universo mutável. Pelo fato de viver em um contexto de mudanças, ele pode reconstruir a realidade pela memória e descobrir leis para prever e controlar sucessões futuras. A consciência da existência dessas mudanças, contínuas ou descontínuas, foi suficiente para Fraisse concluir que o tempo pode ser considerado como o marcador e indicador dos momentos de mudança (BUENO, 1985).

A tradição ocidental, no decorrer da história, tem abordado a noção de tempo de diversas maneiras. Os primeiros filósofos, orientados por uma ciência ainda especulativa, já se preocupavam com o entendimento da realidade à qual o tempo podia corresponder. Entretanto, ainda não tinham o conhecimento necessário para explicar questões que relacionavam o tempo e o movimento. Num segundo momento, a idéia de tempo esteve ligada a referências sobre Deus e o mundo. Para Platão, o tempo era uma imagem móvel da eternidade. Com Descartes, a reflexão se volta para o homem, por meio de uma idéia de tempo que correspondia a nossa experiência interior de duração, ou seja, a questão passa a ser de caráter mais epistemológico do que psicológico. Segundo Kant, o tempo é entendido como uma forma pura de intuição sensível, a partir da verificação sobre o estado de consciência humano, no qual o tempo pode ser definido como uma categoria que fundamenta as leis da ciência. Para Bergson, o tempo passa a ser entendido como uma atitude permanente do espírito humano, ou seja, a partir da noção de junção entre a observação psicológica dos estados de consciência humana com um tempo metafísico. Esta dimensão de temporalidade ainda vai aparecer nos escritos de Merleau-Ponty, Heidegger e Husserl, no intuito de explicar o tempo como sendo uma dimensão do próprio ser humano (Bueno, 1985). Finalmente, desde a metade do século XXI, desenvolve-se o estudo empírico da precisão com a qual os homens percebem o tempo por meio da Psicofísica, ciência que estuda a percepção do tempo a partir 
de estudos sobre o que o homem faz em reação às situações em que ele se encontra. De forma geral, estes estudos estiveram embasados em metodologias que visam a tarefas de reprodução ou comparação de intervalos temporais, o que tornou possível a consolidação de uma metodologia capaz de dar conta em estudar a percepção temporal subjetiva humana (BUENO, 1985).

\subsubsection{PRINCIPAIS MODELOS SOBRE O PROCESSAMENTO TEMPORAL} HUMANO

A literatura destaca quatro modelos para explicar o processamento temporal humano.

O modelo de armazenamento, proposto por Ornstein (1969), parte do pressuposto de que o processamento cognitivo estaria alicerçado na estocagem de reservas de memória: quanto maior é a quantidade e a complexidade da informação, maior é o espaço requerido pela memória e, por conseqüência, maior é a estimação temporal.

O modelo atencional, proposto por Hicks, Miller e Kinsbourne (1976) sugere que o processamento cognitivo se dá a partir da distribuição de reservas de memória, solicitada pelo grau de atenção exigido para o cumprimento da tarefa de estimação: quanto maior é a demanda atencional do sujeito à tarefa, maior é o esforço mental exigido para que as informações temporais sejam arquivadas na memória e, por esta razão, maior a estimação temporal. Este modelo difere do modelo de armazenamento na medida em que nem sempre a complexidade da informação de um estímulo temporal padrão é o elemento que demanda maior esforço atencional do sujeito durante a tarefa de estimação. 
O modelo de expectativa, proposto por Boltz (1991) baseia-se no contraste entre durações percebidas e esperadas. É possível antecipar o final de um evento, baseando-se no quotidiano, que nada mais é do que uma sucessão de estímulos com começos e finais não arbitrários. Desse modo, dependendo do grau de familiaridade a um estímulo presente, é possível que o sujeito preveja o seu final. Em oposição, qualquer manipulação no final do estímulo observado, ocasionará aumento da expectativa no sujeito, que a interpretará como uma surpresa momentânea. Estas surpresas são formalizadas como contrastes temporais e representam diferenças assinaladas entre finalizações esperadas e observadas. Assim, o modelo de expectativa sugere que, se o final de um evento confirma a expectativa pela sua ocorrência no "tempo certo" (contraste zero), então a duração estimada será precisa. Entretanto, eventos finalizando depois do esperado (contraste positivo) parecerão relativamente longos, causando superestimações. Inversamente, os eventos que finalizam antes do esperado (contraste negativo) parecerão relativamente curtos, podendo causar subestimações.

O modelo proposto por Gibbon, Church e Meck (1984) baseia-se na existência de um relógio interno que avalia o tempo objetivo (externo) de maneira subjetiva. De acordo com a sua teoria do "timing escalar", este mecanismo de relógio interno é composto por um marcapasso que emite pulsos e um interruptor que controla a atenção temporal. Este interruptor (que nada mais é senão um emissor de pulsos) é acionado e paralisado, respectivamente, do início ao fim do estímulo, permitindo, assim, um acúmulo de pulsos durante a apresentação do evento a ser estimado. A estimação temporal, então, está baseada em um número de pulsos acumulados: quanto maior o número de pulsos, maior o tempo a ser julgado. 


\subsubsection{METODOLOGIAS EMPREGADAS PARA MENSURAR A PERCEPÇÃO TEMPORAL HUMANA}

Zakay (1990), através de seu modelo de estimação temporal, descreve diversas maneiras de se estudar o tempo subjetivo. Segundo o autor, vários fatores contribuem para que medidas precisas de estimação temporal sejam efetuadas, como o tipo de comportamento temporal envolvido, as características do período de tempo que o sujeito experimenta um evento, as características do experimentador, o tipo de tarefa que o sujeito executa etc. $\mathrm{O}$ autor supõe que o completo entendimento de qualquer tipo de experiência temporal é possível somente se considerarmos uma interação entre esses fatores.

Zakay (1990) define quatro possibilidades para a mensuração da percepção temporal humana:

1) Estimação verbal: a duração do intervalo-alvo é estimada verbalmente em termos de unidades temporais (segundos, minutos, horas, etc.). Por exemplo: após realizar uma tarefa de apreciação temporal a um intervalo dado (por exemplo, 20 segundos), perguntase ao sujeito qual foi o tempo de sua apreciação; o sujeito deve, então, responder verbalmente à pergunta;

2) Produção temporal: produz-se um intervalo pré-definido de uma determinada duração. Por exemplo: pede-se ao sujeito que ele produza 20 segundos por meio de dois sinais (estalares de dedos, por exemplo): o primeiro sinal representa o início de sua produção temporal; quando o sujeito achar que 20 segundos já se passaram a partir do primeiro sinal dado, então ele deve dar o segundo sinal ao experimentador, indicando o final de sua produção temporal; 
3) Comparação temporal: dois intervalos de tempo são apresentados ao sujeito e ele julgará qual será o maior. Por exemplo: duas durações sonoras (uma de 20 segundos, outra de 30 segundos) são apresentadas ao sujeito e ele, então, após a apreciação temporal, deve indicar ao experimentador qual foi a duração mais longa;

4) Reprodução temporal: o intervalo alvo é reproduzido através de alguma operação e o sujeito utiliza algum instrumento de medição do tempo. Por exemplo: após apreciar qualquer evento, o sujeito então deve reproduzir a duração do mesmo por meio de um cronômetro: apertando o botão "iniciar", o cronômetro dispara; quando o sujeito achar que o tempo de duração do evento apreciado anteriormente for igual ao tempo de duração contado a partir do momento em que ele apertou o botão "iniciar" do cronômetro, então o sujeito deve apertar o botão "finalizar" do cronômetro, consolidando, assim, a reprodução temporal de um evento.

Zakay (1990) também define, em seu modelo de estimação temporal, dois paradigmas a serem utilizados em estudos dessa espécie: o paradigma prospectivo, em que o sujeito é instruído sobre todas as suas tarefas de estimação temporal antes da execução do experimento e o paradigma retrospectivo, onde o sujeito executa as tarefas por etapas, sendoThe apresentada uma tarefa de cada vez, no decorrer do experimento. Block e Zakay (1997) apontam uma duração experienciada no paradigma prospectivo e uma duração relembrada no paradigma retrospectivo. Dois seriam, portanto, os critérios para a mensuração subjetiva do tempo: os julgamentos prospectivos seriam baseados no registro de unidades temporais, acumuladas e armazenadas na memória, em condições de competição de atenção com a atenção dedicada a informações não temporais do mesmo intervalo. Quanto mais complexa e mais absorvente a informação, menor a atenção ao tempo e menor a duração subjetiva. Modelos relativos à duração "relembrada" ou retrospectiva não postulam a existência de um mecanismo temporizador, porque supõem que, na ausência de um aviso prévio, os indivíduos 
normalmente não prestam atenção à passagem do tempo: para seus julgamentos, eles levam em conta apenas o conteúdo da informação lembrada (ADES, 1991). Processos psicológicos diferentes podem subjazer ao emprego de estratégias prospectivas ou retrospectivas em procedimentos de estudo do tempo subjetivo.

A literatura aponta para a existência de uma heterogeneidade metodológica nos estudos envolvendo a estimação temporal. Diferentes resultados têm sido obtidos em pesquisas deste cunho, por conta dos paradigmas utilizados, do método de estimação, dos conteúdos da duração a ser estimada, do engajamento do sujeito com a tarefa, da modalidade sensorial a ser estudada, etc. Isso denota uma falta de precisão com relação à dicotomia cognição versus metodologia. A pergunta aqui é: processos psicológicos diferentes são evocados paralelos à metodologia utilizada ou metodologias diferentes evocam processos comuns?

\subsubsection{O PAPEL DAS EMOÇÕES NA PERCEPÇÃO TEMPORAL HUMANA}

A literatura oferece evidências de que existe realmente uma ligação da percepção das expressões emocionais com as tendências de ação humanas. Se as emoções induzidas pela percepção de faces ou outros estímulos emocionais influenciam a percepção da passagem do tempo, isto pode ter importantes implicações para a velocidade com a qual os animais e os humanos respondem a estímulos em seus ambientes. Por exemplo: se o tempo parece passar mais rápido quando um animal tem uma expressão facial agressiva, então ele pode estar capacitado a dar respostas mais rápidas ao ambiente que o rodeia (BUENO, 1985; DROIT-VOLET; MECK, 2007). 
Os estudos encontrados na literatura que têm averiguado a influência das emoções na percepção temporal humana revelam resultados inconsistentes e contraditórios. Alguns estudos demonstraram que não há um efeito da emoção na passagem do tempo (FRAISSE, 1967; SHIFF; THAYER, 1968), enquanto outros estudos demonstraram influências inconsistentes, incluindo superestimação temporal (WATTS; SHARROCK, 1984) e subestimação temporal (ORME, 1969).

Em estudo recente realizado por Angrilli et al. (1997), participantes realizaram tarefas de reprodução temporal e de estimação verbal após serem submetidos à visualização de figuras que variavam quanto à valência afetiva (positiva ou negativa) e quanto à intensidade (alta ou baixa). Estas imagens foram classificadas em cinco grupos: imagens que evocavam valências afetivas altas e estados de ativação altos (material erótico), imagens que evocavam valências afetivas altas e estados de ativação baixos (bebês e filhotes de animais), imagens classificadas como neutras (objetos domésticos), imagens que evocavam valências afetivas baixas e estados de ativação baixos (aranhas e ratos) e imagens que evocavam valências afetivas baixas e estados de ativação altos (ferimentos envolvendo sangue humano). Os autores utilizaram escalas de diferencial semântico de 9 pontos, utilizando as locuções "triste/alegre" e "calmo/ativo". Também foram utilizadas as medidas de condutância de pele e batimento cardíaco referentes aos estados afetivos analisados. Os resultados revelaram uma interação entre essas duas variáveis: para situações de altos índices de arousal, a duração de figuras que sugeriam valências afetivas negativas foi superestimada em relação à duração de figuras que sugeriam valência afetiva neutra ou positiva; para situações de baixos índices de arousal, figuras que sugeriam valência afetiva negativa foram subestimadas e figuras que sugeriam valência afetiva positiva foram superestimadas. Os autores concluíram que ambos os mecanismos de atenção e arousal desempenham um papel importante na percepção da duração de eventos emocionais. 
Por outro lado, também existem evidências de que condições positivas causam superestimação do tempo. Edmonds, Cahoon e Bridges (1981) realizaram um experimento no qual um determinado tempo de espera podia ser seguido de um evento agradável ou de um evento desagradável ou, ainda, de uma experiência neutra. O grupo com expectativa positiva apresentou uma estimação mais longa do tempo em relação aos outros.

$\mathrm{Na}$ tentativa de esclarecer quais os mecanismos que estão por trás da influência das emoções na percepção temporal, Gautier e Droît-Volet (2002) realizaram alguns estudos sobre o tema apropriando-se de tarefas de bissecção temporal. Neste tipo de tarefa, os participantes aprendem a categorizar durações-padrão como curtas ou longas. Em uma segunda etapa, eles devem julgar se a comparação das durações de um mesmo intervalo de tempo e de intervalos médios são mais similares às durações-padrão curtas ou longas. Esta tarefa permite ao pesquisador derivar funções psicofísicas que determinam a proporção de respostas longas sobre a comparação das durações. Estas funções psicofísicas obtidas têm mostrado que os humanos sabem estimar o tempo de forma acurada.

Em outro estudo, Droit-Volet, Brunot e Niedenthal (2004) usaram durações padronizadas apresentadas em uma forma oval cor-de-rosa e durações de comparação em forma de figuras de faces humanas femininas com expressões faciais neutras, com raiva, tristes e alegres. Os resultados apontaram que quando as imagens foram mostradas em uma duração que variava de 400 a $1.600 \mathrm{~ms}$, que sugere que adultos sistematicamente superestimaram as durações das imagens de conteúdo emocional em relação às imagens neutras. Baseados no Modelo do Relógio Interno, Gibbon, Church e Meck (1984) acreditam que a superestimação temporal esteja ligada ao crescimento do arousal que, através da liberação de uma substância chamada dopamina, faz com que a velocidade do marcador temporal humano aumente. Estes achados foram replicados por Effron et al. (2006), que utilizaram uma tarefa de bissecção temporal similar, com figuras humanas femininas 
expressando raiva e alegria. Em ambos os estudos, a superestimação temporal foi maior para as expressões de raiva do que para outras expressões emocionais ${ }^{2}$.

\subsubsection{O USO DA MÚSICA NO ESTUDO DA PERCEPÇÃO TEMPORAL HUMANA}

A percepção temporal humana tem sido analisada por diversos pesquisadores, baseando-se na quantidade de mudanças percebidas pelo sujeito no decorrer de um evento (FRAISSE, 1967). As características perceptivas da música, que se organizam em diferentes níveis em sua estrutura rítmica, harmônica e/ou melódica, fazem com que ela seja um evento adequado para estudos sobre a percepção temporal humana. Segundo Berlyne (1974), a simples repetição de um som é suficiente para fornecer todos os elementos da percepção do tempo. Quando o segundo som é produzido, ele reproduz num certo sentido o primeiro som, cuja imagem ainda fica presente na mente do sujeito; assim, a invocação do primeiro som pelo segundo fornece o início; a percepção do segundo som fornece o fim; e a persistência da imagem (na mente do sujeito) fornece a duração do intervalo apreciado; uma série de fatos da consciência forma uma relação temporal porque entre estes fatos há sempre um grande número de representações duráveis; o tempo nasce desta sucessão e da relativa simultaneidade das formulações psíquicas. Assim, a utilização de trechos musicais como estímulo-padrão pode contribuir para a investigação do processamento cognitivo-temporal humano (BUENO, 1985).

Bueno, Firmino e Engelmann (2002) analisaram dois trechos musicais de mesma duração: os 90 primeiros segundos de uma obra de Gustav Mahler (considerada como baixa complexidade musical) e os 90 primeiros segundos de uma metalinguagem acerca do mesmo tema, composta por Luciano Bério. Esta última obra é dotada de alta complexidade

\footnotetext{
${ }^{2}$ A raiva é uma emoção que sugere alto grau de arousal (RUSSEL, 1980).
} 
musical, por tratar-se de música de vanguarda, e contém um número maior de elementos musicais (instrumentos, vozes, acordes, síncopas) em relação à primeira. Os resultados mostraram uma superestimação do tempo subjetivo da obra de Bério em relação à obra de Mahler, comprovando que, ao empregar-se uma estratégia prospectiva, quanto maior a complexidade musical generalizada de um evento, maior a estimação subjetiva do tempo. A variável essencial para a superestimação da obra de Bério foi a existência de uma maior densidade estrutural, uma vez que os sujeitos desconheciam as dissonâncias e complementos contidos nessa obra.

Ramos (2004) realizou um estudo cujo objetivo foi verificar se a música modal, expressando diferentes estados de ânimo, influencia na estimação subjetiva do tempo. Para tal, utilizou a música modal, através do uso dos modos Jônio (de caráter maior, consonante), Eólio (de caráter menor, consonante) e Lócrio (de caráter menor, dissonante ao ouvido ocidental). Os estados afetivos analisados foram: alegria, familiaridade, tensão e ativação. Participaram do experimento estudantes universitários, de ambos os sexos e não músicos, divididos em três grupos, relacionados a cada estímulo musical empregado (Jônio, Eólio e Lócrio). Cada participante foi submetido individualmente às seguintes tarefas, sob o paradigma retrospectivo de estimação de tempo: audição do trecho musical, estimação temporal por reprodução do mesmo trecho e preenchimento de escalas com valores de 1 a 7 , referente ao conteúdo subjetivo das emoções analisadas no estudo. Os resultados indicaram superestimação temporal por reprodução para o estímulo Lócrio em relação aos estímulos Eólio e Jônio. Concluiu-se, neste estudo, que o caráter dissonante e não familiar ao ouvido musical ocidental do modo Lócrio pode ter sido o fator responsável pela superestimação temporal deste modo em relação aos demais. Os resultados levantam a hipótese de que a emoção musical, aliada ao caráter consonante ou dissonante de um trecho musical, pode ser o fator responsável pela alteração da percepção temporal em sujeitos não músicos. 


\subsection{O MODO MUSICAL}

Tanto a teoria da música quanto a literatura científica revelam grande contradição na definição da palavra modo. A grande maioria de estudos científicos que utilizaram a palavra modo refere-se ao caráter de uma escala musical, baseado na característica da terceira nota desta escala musical: se a terceira nota da escala for maior, então o modo é maior; se a terceira nota da escala musical for menor, então o modo é menor (BIGAND et al., 2005; DALLA BELLA et al., 2001b; GAGNON; PERETZ, 2003; HEVNER, 1935, 1936; JUSLIN; SLOBODA, 2001; KHALFA et al., 2002; MEYER, 1956; PERETZ; ZATORRE, 2003). Em outras palavras, estes autores utilizaram a palavra modo no contexto da Harmonia Tonal.

No entanto, o uso da palavra modo, neste estudo, refere-se aos modos utilizados na Grécia Antiga e que foram retomados na improvisação jazzística no início do século XX. Cada um destes modos (Jônio, Dórico, Frígio, Lídio, Mixolídio, Eólio e Lócrio) possui diferentes organizações intervalares dentro de sua escala. Portanto, o significado da palavra modo, neste estudo, tem um significado diferente do que quando a palavra modo refere-se ao caráter de uma escala. Por exemplo: o modo Jônio é um modo maior, ou seja, músicas construídas a partir da escala Jônia possuem um intervalo de terça maior entre a primeira nota da escala e a terceira; o modo Eólio é um modo menor, ou seja, músicas construídas a partir da escala Eólia possuem um intervalo de terça menor entre a primeira nota da escala e a terceira; e assim por diante. Em outras palavras, neste estudo a palavra modo será utilizada no contexto da Harmonia Modal (GOULDIN, 1997).

Para evitar confusão entre o significado da palavra modo no decorrer deste estudo, a opção foi utilizar a definição mais próxima possível deste significado, salientada por Dalla Bella et al., (2001a), em que modo significa uma organização específica de intervalos 
construídos sobre uma escala musical. Assim, quando aparecer a utilização da palavra "Modo Lídio", por exemplo, significa dizer que a música foi construída na escala musical Lídia (e que esta escala, dependendo de sua terceira nota musical, pode ser maior ou menor).

\subsubsection{A CONTRIBUIÇÃO DOS MODOS GREGOS PARA O ESTUDO DAS EMOÇÕES MUSICAIS}

Trechos musicais construídos a partir da harmonia modal podem ser utilizados para tentar explicar a influência das emoções musicais na percepção temporal humana devido a vários fatores:

1) A música modal era utilizada na Grécia Antiga como forma de expressão das sociedades da época, onde o emprego de cada modo estava relacionado a um significado emocional específico. O modo Dórico, por exemplo, estava associado à energia e situações de vigor físico. Já o modo Jônio estava associado às festas e à religiosidade. O modo Frígio, muitas vezes, era associado à sensualidade, etc. (GROUT; PALISCA, 1994);

2) Modos maiores e menores são apenas dois exemplos dos sete modos eclesiásticos, utilizados na música ocidental. Os modos eclesiásticos começaram a ser utilizados inicialmente na Grécia, na Idade Antiga e posteriormente, com alguma alteração, foram utilizados na música da Idade Média. Especificar a alteração do uso dos modos, bem como as diferenças de uso em ambos os períodos não se faz necessário para justificar o seu uso neste estudo. No entanto, sabe-se que em ambos os períodos, estes sete modos (Jônio, Dórico, Frígio, Lídio, Mixolídio, Eólio e Lócrio) estavam sempre associados a diferentes contextos sociais, no intuito de sugerir humores específicos nos ouvintes, alguns deles, inclusive, sendo mais apropriados para alguns contextos do que outros (LOVELOCK, 2001). 
A partir do século XVI, com o emprego mais freqüente do uso da música tonal (em substituição à música modal), o modo Jônico e o modo Eólio (com alguma modificação) começaram a dominar a preferência dos compositores dos períodos subseqüentes. E essa "preferência" perdura até os dias atuais (GROUT; PALISCA, 1994). No entanto, os outros cinco modos (Dórico, Frígio, Lídio, Mixolídio, Eólio e Lócrio) nunca caíram em desuso no decorrer da História da Música e vários grandes compositores usaram alguns deles, tanto na música erudita, como, por exemplo, Liszt, Rachmaninòv, Bela Bàrtok, como na música popular e na improvisação jazzística, como, por exemplo, Chick Korea, Keith Jarret, Bill Evans, entre outros (LEVINE, 1989). Além disso, estes modos foram utilizados comumente na música brasileira, tanto pelos eruditos, como Villa Lobos, Guerra Peixe, Alberto Nepomusceno, quanto pelos populares, como Tom Jobim, Milton Nascimento, Djavan, Braguinha, entre outros (PAZ, 2002). Os sete modos têm, assim, uma longa história e ainda estão vivos, em vários estilos musicais, sugerindo que suas organizações específicas toquem em um sólido processo de respostas emocionais que regem a música (RAMOS; BUENO; BIGAND, no prelo).

\subsubsection{A COGNIÇÃO DO MODO MUSICAL}

De um ponto de vista cognitivo, a característica fundamental para o uso dos modos eclesiásticos é a de que eles são construídos sobre um conjunto fixo de sete notas musicais (dó, ré, mi, fá, sol, lá e si) e, conseqüentemente, sobre distribuições intervalares específicas, de forma que cada modo possui uma nota musical atuando como referência. A especificidade de cada modo está fortemente associada aos intervalos musicais formados entre a nota referência e as outras notas musicais que o modo possui. A Figura 2 ilustra os modos musicais, a partir de cada uma de suas respectivas notas de referência: 

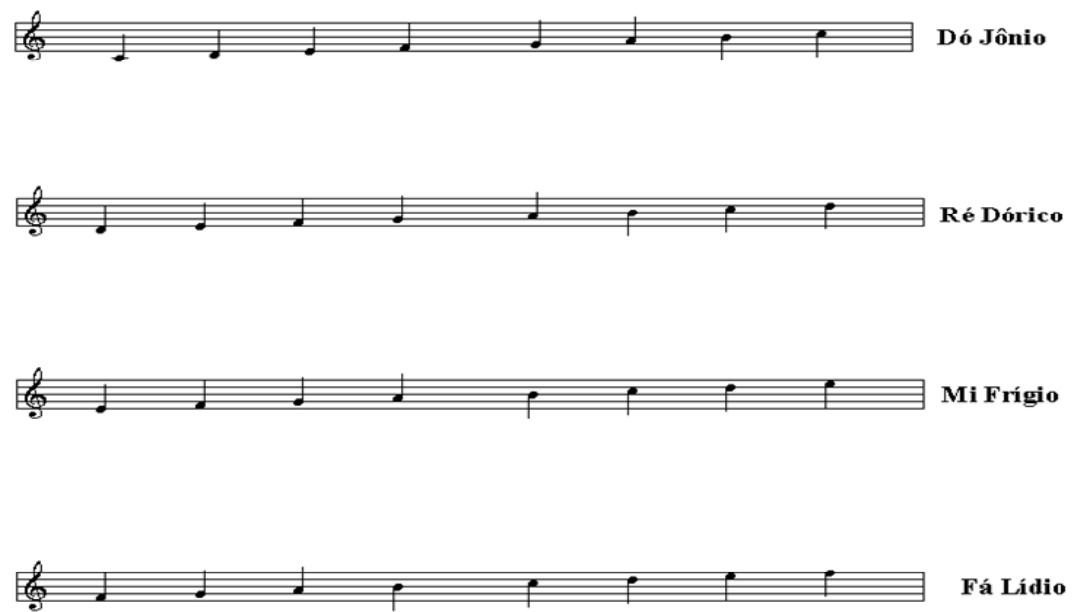

Fá Lídio

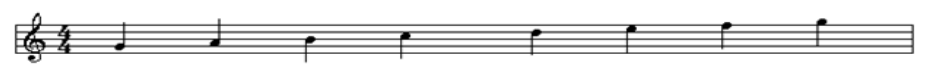

Sol Mixolídio

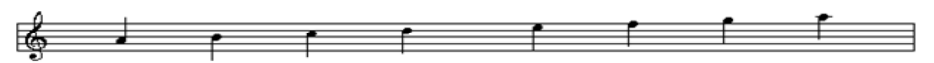

Lá Eólio

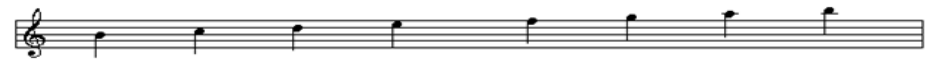

Si Lócrio

Figura 2. Os modos gregos, a partir de cada uma de suas respectivas notas de referência.

Segundo a Figura 2, no modo Jônico, (correspondente ao conhecido "Modo Maior"), a nota dó atua como a nota referencial. No modo Dórico, a nota ré atua como nota de referência. Os outros modos (Frígio, Lídio, Mixolídio, Eólio e Lócrio) têm, respectivamente, as notas mi, fá, sol, lá e si como notas de referência. Estes modos podem ser transpostos para diferentes tonalidades, mas, por conveniência, vamos remeter à explicação cognitiva dos modos na tonalidade de dó maior. Nos modos Jônio, Lídio e Mixolídio, o intervalo entre a nota de referência e a terceira nota de cada modo é de quatro semitons, o que define um intervalo de terça maior e, por essa razão, estes três modos são classificados como modos maiores. Em contrapartida, nos modos Dórico, Frígio, Eólio e Lócrio, este intervalo é de três 
semitons, o que define um intervalo de terça menor e, por essa razão, estes quatro modos são classificados como modos menores. Assim, é o intervalo de terça (maior ou menor) que define o caráter (maior ou menor) de cada modo musical.

Os modos musicais divergem em vários outros intervalos relacionados à nota de referência. Por exemplo, no modo Lídio, o intervalo entre a nota de referência e a quarta nota do modo é um intervalo de seis semitons (quarta aumentada ou quinta diminuída). Este intervalo, também chamado de trítono, é bastante dissonante ao ouvido musical ocidental, tendo sido designado como o "intervalo do diabo" no passado, sugerindo um efeito emocional “diabólico” muito específico (GROUT; PALISCA, 1994; WISNIK, 2004). Este mesmo intervalo não é encontrado nos modos Jônico e Mixolídio. Comentários similares poderiam ser feitos em relação aos modos menores (Dórico, Frígio, Eólio e Lócrio), porque cada um destes modos possui intervalos musicais distintos em relação às suas respectivas notas de referências. Portanto, pode-se inferir que, além da terceira nota de cada modo musical, os outros intervalos (segundas, quartas, quintas, sextas e sétimas) relacionados a cada nota de referência contribuem para a expressão emocional específica de cada modo.

\subsubsection{A HIERARQUIA MODAL}

De acordo com Wisnik (2004), essas mudanças relacionadas às distâncias intervalares entre as notas de referência e as outras seis notas de cada modo permitem organizar uma hierarquia modal linear, que leva em conta o grau de "obscuridade" ou "claridade" que cada modo pode desencadear durante uma escuta musical.

A Figura 3 mostra a hierarquia modal sugerida por Wisnik (2004): 


\begin{tabular}{|c|c|c|c|c|c|c|c|c|}
\hline Modo & Característica & Análise & \multicolumn{6}{|c|}{ Intervalos formados em sua escala } \\
\hline Lídio & Maior & Escala maior com $4^{\mathrm{a}}$ aumentada & $2^{\mathrm{a} M}$ & $3^{\mathrm{a} M}$ & $4^{\mathrm{a}}$ Aum & $5^{\mathrm{a} J}$ & $6^{\mathrm{a} M}$ & $7^{a} \mathrm{M}$ \\
\hline Jônio & Maior & Escala maior tradicional & $2^{\mathrm{a} M}$ & $3^{\mathrm{a} M}$ & $4^{\mathrm{a} J}$ & $5 \mathrm{~J}$ & $6^{\mathrm{a} M}$ & $7^{\mathrm{a} M}$ \\
\hline Mixolídio & Maior & Escala maior $\operatorname{com} 7^{\mathrm{a}}$ menor & $2^{\mathrm{a} M}$ & $3^{\mathrm{a} M}$ & $4^{\mathrm{a}} \mathrm{J}$ & $5^{\mathrm{a} J}$ & $6^{\mathrm{a} M}$ & $7^{\mathrm{a} m}$ \\
\hline Dórico & Menor & Escala menor com $6^{\text {a }}$ maior & $2^{\mathrm{a} M}$ & $3^{\mathrm{a} m}$ & $4^{\mathrm{a}} \mathrm{J}$ & $5^{\mathrm{a} J}$ & $6^{\mathrm{a} M}$ & $7^{\mathrm{a} m}$ \\
\hline Eólio & Menor & Escala menor tradicional & $2^{\mathrm{a} M}$ & $3^{\mathrm{a} m}$ & $4^{\mathrm{a} J}$ & $5 \mathrm{~J}$ & $6^{\mathrm{a}} \mathrm{m}$ & $7^{\mathrm{a} m}$ \\
\hline Frígio & Menor & Escala menor com $2^{\mathrm{a}}$ menor & $2^{\mathrm{a}} \mathrm{m}$ & $3^{\mathrm{a} m}$ & $4^{\mathrm{a} J}$ & $5 \mathrm{~J}$ & $6^{\mathrm{a}} \mathrm{m}$ & $7^{\mathrm{a} m}$ \\
\hline Lócrio & Menor & Escala menor com $2^{\mathrm{a}}$ menor e $5^{\mathrm{a}}$ diminuta & $2^{\mathrm{a}} \mathrm{m}$ & $3^{\mathrm{a} m}$ & $4^{\mathrm{a}} \mathrm{J}$ & 5a'Dim & $6^{\mathrm{a}} \mathrm{m}$ & $7^{\mathrm{a}} \mathrm{m}$ \\
\hline
\end{tabular}

Figura 3. Hierarquia modal sugerida por Wisnik (2004).

Conforme esta hierarquia, os três primeiros modos (Lídio, Jônio e Mixolídio) classificam-se como maiores. O modo Jônio corresponde ao modo maior padrão, com intervalos de $3^{\mathrm{a}}$ maior, $6^{\mathrm{a}}$ maior e $7^{\mathrm{a}}$ maior, que caracterizam uma escala tonal maior (HINDEMITH, 1944). No entanto, o modo Lídio corresponde ao modo maior padrão com um intervalo de quarta aumentada. Portanto, é o "modo mais claro", porque não há nenhum outro modo com intervalos tão ascendentes quanto o modo Lídio. O modo Mixolídio corresponde ao modo maior padrão com um intervalo de sétima menor (descendente) e, portanto, está mais longe da "claridade" do que os modos Lídio e Jônio, respectivamente. A partir do modo Mixolídio, todos os outros modos são menores. O modo Eólio corresponde ao modo menor padrão, com intervalos de $3^{\mathrm{a}}$ menor, $6^{\mathrm{a}}$ menor e $7^{\mathrm{a}}$ menor, caracterizando, assim, uma escala menor tradicional (HINDEMITH, 1944). No entanto, o modo Dórico corresponde ao modo menor padrão com um intervalo de $6^{\mathrm{a}}$ maior (ascendente) e, portanto, sendo o modo menor mais perto da "claridade", relacionada aos modos maiores. O modo Frígio corresponde ao modo menor padrão, com um intervalo descendente de $2^{\mathrm{a}}$ menor, estando assim, mais perto da "obscuridade" do que os modos Dórico e Eólio, respectivamente. Finalizando a hierarquia, temos o modo Lócrio, considerado como "o mais obscuro", porque não há nenhum outro modo que possui intervalos tão descendentes quanto este modo (o modo Lócrio corresponde ao modo menor padrão com $2^{\mathrm{a}}$ menor e $5^{\mathrm{a}}$ diminuta). 
Não foi objetivo deste estudo a realização de um estudo aprofundado sobre a hierarquia modal sugerida por Wisnik (2004). No entanto, esta hierarquia sugere uma explicação lógica e linear para justificar o uso dos modos no presente estudo. A partir das diferentes organizações intervalares presentes em cada modo, é possível inferir que cada um deles desencadeie emoções distintas nos ouvintes. Além disso, os estudos existentes acerca do processamento emocional humano já revelaram resultados concisos sobre as características estruturais da música que interferem ou determinam o desencadeamento de emoções específicas nos ouvintes. Estes estudos utilizaram músicas construídas em apenas duas escalas (Tonal Maior e Tonal Menor). Acredita-se, portanto, que o uso de mais escalas (no caso, sete), possa dar conta de descobertas ainda mais específicas sobre o processamento das emoções musicais nos ouvintes. Assim, se o modo maior (no caso, o modo Jônio) está associado à Alegria e o modo menor (no caso, o modo Eólio) está associado à Tristeza (HEVNER, 1935; DALLA BELLA et al., 2001a), então, uma hipótese a ser considerada é a de que, quanto mais próximo o modo estiver da "claridade", maiores serão os níveis de Alegria percebidos pelos ouvintes; por outro lado, quanto mais próximo o modo estiver da “obscuridade", maiores serão os níveis de Tristeza percebidos pelos ouvintes durante as escutas musicais.

Este estudo utilizou trechos musicais modais no intuito de verificar a influência das emoções percebidas durante uma escuta musical sobre a percepção temporal de músicos e não músicos. 
2. OBJETIVOS 
A proposta deste trabalho é dar continuidade ao trabalho de Ramos (2004), tendo como objetivos:

1) Verificar respostas emocionais de músicos e não músicos a trechos musicais (do repertório erudito ocidental) pertencentes aos períodos Barroco, Clássico, Romântico e Contemporâneo (experimento I);

2) Agrupar os trechos musicais empregados no experimento I em categorias emocionais (Alegria, Tristeza, Serenidade, Medo/Raiva) e, a partir dos resultados obtidos, submetê-los a tarefas relacionadas ao processamento temporal, com o objetivo de verificar se a percepção temporal (de músicos e não músicos) é afetada por algum componente emocional presente durante a escuta musical (experimento II);

3) Verificar respostas emocionais de músicos e não músicos a trechos musicais construídos em diferentes modos (Lídio, Jônio, Mixolídio, Dórico, Eólio, Frígio e Lócrio) e diferentes andamentos musicais (adágio, moderato e presto) (experimento III);

4) Verificar se a percepção temporal (de músicos e não músicos) é afetada: (a) por emoções específicas desencadeadas durante a escuta musical (componente emocional da música); (b) por mudanças relacionadas a alterações de dois parâmetros musicais, como o modo e o andamento musical (componente estrutural da música); ou (c) pela interação entre estes dois componentes, o emocional e o estrutural, (experimento IV). 
Objetivos 
3. EXPERIMENTOS 
3.1. EXPERIMENTO I 


\subsubsection{INTRODUÇÃO}

Vários estudos têm sido desenvolvidos no intuito de mensurar as emoções desencadeadas durante uma escuta musical (GABRIELSSON; JUSLIN, 2003; GABRIELSSON; LINDSTRÖM，2001; GABRIELSSON，2001; ROBINSON， 1997; JUSLIN; SLOBODA, 2001). Os resultados destas pesquisas mostraram que os ouvintes percebem as emoções musicais de forma coerente, ou seja, altos índices de associações emocionais equivalentes para músicas iguais têm sido observados. Esta coerência foi encontrada em adultos e crianças (DALLA BELLA et al., 2001b), bem como entre participantes de diferentes culturas (BALKWILL; THOMPSON, 1999). Também foram feitas comparações de respostas emocionais a trechos musicais idênticos pelos mesmos participantes após várias semanas - teste/re-teste - (BIGAND et al., 2005). Estes achados reforçam a idéia de que as emoções musicais dependem mais da cognição dos elementos da estrutura musical de uma obra do que da história pessoal de cada um (BIGAND et al., 2005).

Há um consenso a respeito da associação das emoções musicais a cinco categorias principais: alegria, serenidade, raiva, medo e tristeza (RUSSEL, 1980). Segundo Juslin e Laukka (2004), estas emoções são "mais fáceis" de serem desencadeadas durante uma escuta musical e por isso foram denominadas emoções musicais de base.

Além disso, há uma série de estudos que utilizam medidas de arousal e de valência afetiva para mensurar as emoções desencadeadas durante uma escuta musical (RUSSEL, 1980; BIGAND et al., 2005; RAMOS, BUENO; BIGAND, no prelo). Estes estudos procuram associar músicas a quatro possibilidades, envolvendo estas duas dimensões: músicas que desencadeiam arousal e valência afetiva positivos; músicas que desencadeiam arousal e valência afetiva negativos; músicas que desencadeiam arousal positivo e valência 
afetiva negativa; e, finalmente, músicas que desencadeiam arousal negativo e valência afetiva positiva.

Pelo fato de alguns estudos terem mostrado pequenas diferenças de processamento de emoções de base desencadeadas por músicas do repertório erudito ocidental entre grupos de ouvintes músicos e não músicos (WATERMAN, 1996; KOELSCH et al., 2000; SCHERER; ZENTNER, 2001; BIGAND; POULIN-CHARRONNAT, no prelo), a expertise musical foi uma variável mensurada no presente experimento. A expertise musical pode ser definida, no presente estudo, como a aquisição progressiva do estudo sistematizado de algum instrumento musical (GALVÃO, 2006). Estudos que procuram verificar a influência da expertise musical sobre as respostas emocionais têm mostrado que músicos processam a informação emocional de forma mais "refinada" do que não músicos e, portanto, há mais consistência nas respostas emocionais dos músicos em relação às respostas emocionais dos não músicos. Isso significa que maiores são as chances de um mesmo trecho musical estar associado a uma única emoção em uma amostra de músicos do que em uma amostra de não músicos.

Pelo fato de existirem evidências de que o processamento emocional dos músicos seja diferente do processamento emocional dos não músicos durante uma escuta musical, o primeiro passo do presente trabalho foi, portanto, encontrar estímulos musicais desencadeadores de emoções específicas nos ouvintes de ambos os grupos. Em uma segunda etapa, estes estímulos musicais puderam ser submetidos a tarefas de processamento temporal, no intuito de verificar a influência das emoções percebidas durante uma escuta musical na percepção temporal de músicos e não músicos.

Portanto, a realização deste experimento teve dois objetivos: o primeiro foi o de verificar se trechos musicais do repertório erudito ocidental, pertencentes aos períodos Barroco, Clássico, Romântico e Contemporâneo, com 36 segundos de duração, desencadeiam 
emoções específicas em ouvintes músicos e não músicos, comparando as respostas emocionais de ambos os grupos; o segundo objetivo foi o de selecionar os trechos musicais que forem mais associados a cada categoria emocional (Alegria, Tristeza, Serenidade, Medo ou Raiva) dentro de cada grupo de participantes, no intuito de verificar a influência das emoções percebidas durante uma escuta musical na percepção temporal de músicos e não músicos (experimento II).

\subsubsection{MÉTODO}

Participantes: a amostra de participantes foi dividida em dois grupos: 16 estudantes de um curso de graduação em Música, que tinham pelo menos seis anos de experiência de estudo sistematizado de algum instrumento musical oferecido pelo curso: piano, violão, violino, viola, violoncelo, contrabaixo, flauta transversal, clarineta, trombone ou saxofone (classificados neste estudo como músicos) e 16 participantes que não tinham nenhuma experiência em estudo de Música (classificados neste estudo como não músicos). Todos os participantes tinham entre 18 e 28 anos de idade (média $=23,4$ anos). Ambos os grupos (músicos e não músicos) eram formados por 8 homens e 8 mulheres.

Equipamento e material: o experimento foi realizado em uma sala de estudos silenciosa, iluminada por lâmpadas fluorescentes e com paredes lisas, sem estímulos visuais que pudessem interferir nas tarefas dos participantes. O espaço interno da sala era preenchido por uma mesa, três cadeiras (uma para o experimentador e as outras duas para os participantes). Sobre a mesa havia dois notebooks (Pentium INTEL), que eram utilizados para apresentação das músicas e para o registro dos julgamentos emocionais, por meio do programa Music and 
Emotion, que foi desenvolvido por Airton Finotti especialmente para este estudo. Conectado a cada notebook havia um fone de ouvido Koss R80 (Signus- Philadélfia, EUA), utilizado pelos participantes para a apreciação das músicas. A disposição dos notebooks na mesa era feita de tal forma que a tarefa de um participante não pudesse interferir na tarefa de outro. Fora da sala experimental, havia duas mesas e duas cadeiras para o preenchimento de um questionário complementar, que continha perguntas relacionadas a dados pessoais, ao grau de conhecimento musical dos participantes e ao próprio experimento.

Estímulos musicais empregados: as músicas escolhidas para este experimento foram 30 trechos de obras do repertório erudito internacional, referentes aos períodos Barroco, Clássico, Romântico e Contemporâneo. Algumas destas músicas $(n=21)$ já haviam sido utilizadas em Bigand et al. (2005). Pelo fato de os arquivos referentes às outras nove músicas restantes utilizadas no estudo de Bigand et al. (2005) não terem sido encontrados para a realização deste estudo, os outros trechos musicais foram selecionados a partir de outro estudo sobre o mesmo tema (JUSLIN; LAUKKA, 2004). Neste estudo, os autores fornecem pistas sobre as características musicais presentes nas obras que induzem emoções específicas nos ouvintes. Assim, as outras nove músicas utilizadas neste experimento tinham características semelhantes àquelas apontadas pelos autores, referentes às emoções Alegria, Serenidade, Tristeza, Medo ou Raiva. A utilização de músicas conhecidas do repertório erudito (como As quatro estações, de Vivaldi) foi evitada. A intensidade na faixa de freqüência média de cada estímulo foi de $50 \mathrm{~dB}$ (confortável para os participantes). Os trechos musicais foram transformados em arquivos do tipo wave, sintetizados em um estúdio de gravação, para melhor equalização do som e depois armazenados nos discos rígidos dos notebooks utilizados na coleta. Cada trecho musical tinha 36 segundos de duração. O título das obras encontra-se na Tabela 1: 
Tabela 1: Trechos musicais empregados no Experimento I.

\begin{tabular}{|c|c|c|}
\hline Trecho Musical & Título da obra & Compositor \\
\hline Trecho Musical 1 & Also sprach Zarathustra & R. Strauss \\
\hline Trecho Musical 2 & Waltz Op. $70, n^{\circ} 03$ & F. Chopin \\
\hline Trecho Musical 3 & Piano Concerto K 488 (adágio) & W. A. Mozart \\
\hline Trecho Musical 4 & Violin Concerto (adágio) & J. Brahms \\
\hline Trecho Musical 5 & Sonata (A) for Harpsichord K 208 & D. Scarlatti \\
\hline Trecho Musical 6 & Träumerei, Op. 15, $n^{\circ} 07$ & R. Schumann \\
\hline Trecho Musical 7 & Sonata for piano Op. $18, n^{\circ} 03$ & S. Prokofièv \\
\hline Trecho Musical 8 & Trio 2 for piano, violin and cello (largo) & D. Shostakovitch \\
\hline Trecho Musical 9 & Tristan, act 03 & W. R. Wagner \\
\hline Trecho Musical 10 & Symphony Bdur, Hob 1, 105 (andante) & J, Haydn \\
\hline Trecho Musical 11 & Poème Symphonique & F. Liszt \\
\hline Trecho Musical 12 & Gnossiènne $n^{\circ} 02$ & E. Satie \\
\hline Trecho Musical 13 & Hungarian Rapsody $n^{\circ} 02$ & F. Liszt \\
\hline Trecho Musical 14 & That certain feeling & G. Gershwin \\
\hline Trecho Musical 15 & Italian Symphony, 1st movement & F. Mendelsohn \\
\hline Trecho Musical 16 & Prèlude $n^{\circ} 24$ & F. Chopin \\
\hline Trecho Musical 17 & Tasso Lamento \& Triomfo & F. Liszt \\
\hline Trecho Musical 18 & Tod und Verklärung 7' to 7'36 & R. Strauss \\
\hline Trecho Musical 19 & Violin Sonata & J. S. Bach \\
\hline Trecho Musical 20 & Scherzo - A truta (presto) & F. Schubert \\
\hline Trecho Musical 21 & Suíte française G - Sarabande & J. S. Bach \\
\hline Trecho Musical 22 & Duetto for two flutes in F (lamentabile) & J. S. Bach \\
\hline Trecho Musical 23 & Trio for piano, violin and horn, 2nd movement (moderato) & J. Brahms \\
\hline Trecho Musical 24 & Petrouchka & I. Stravinsky \\
\hline Trecho Musical 25 & Erwartung & A. Schöenberg \\
\hline Trecho Musical 26 & Trio 2 for violin, cello and piano (moderato) & D. Shostakovitch \\
\hline Trecho Musical 27 & Totentanz & F. Liszt \\
\hline Trecho Musical 28 & O tambor dos granadeiros & L. Chapí \\
\hline Trecho Musical 29 & Violin romance & L. V. Beethoven \\
\hline Trecho Musical 30 & Valse in E minor - póstuma (vivace) & F. Chopin \\
\hline
\end{tabular}

Procedimento: o experimento foi realizado com a presença de dois participantes por vez na sala experimental. Esta medida foi usada para acelerar o processo de coleta de dados, uma vez que um número muito grande de participantes foi necessário para o desenvolvimento desta pesquisa. Os participantes foram conduzidos até a sala experimental. Foram dados 30 segundos para acomodação à situação experimental. $\mathrm{O}$ experimentador, então, mostrou a cada participante o Termo de Consentimento, referente ao Comitê de Ética e Pesquisa. O preenchimento deste termo significava aprovação para participar do experimento por livre e espontânea vontade. Logo em seguida, então, o experimentador explicou: "Vocês vão dar uma contribuição para nossos estudos. Para isso, eu vou pedir que vocês executem pequenas tarefas, uma de cada vez. Peço que vocês escutem todo o procedimento antes do início do 
experimento". Após o consentimento, o experimentador prosseguiu com as instruções: "Vocês vão realizar uma tarefa de julgamentos emocionais sobre as músicas que vocês irão ouvir. Primeiramente, vocês deverão colocar este fone de ouvido e acomodá-lo adequadamente. $\mathrm{Na}$ tela deste notebook existem ícones, cujos nomes estão enumerados de 1 a 30. Por exemplo: Música 1, Música 2, Música 3, e assim por diante. Cada ícone corresponde a uma música. Vocês deverão, então, com a ajuda do mouse, escolher um ícone por vez, aleatoriamente. Importante! Não escolham os ícones em ordem crescente. Escolham-nos em ordem aleatória, por exemplo: 08, 25, 13, 02, e assim por diante. Quando vocês teclarem no ícone escolhido, então soará a música referente a este ícone. Vocês deverão escutá-la até o seu fim, em silêncio. Enquanto a música estiver tocando, a tela do notebook estará apagada. Vocês poderão escutar uma mesma música quantas vezes acharem necessário. Quando a música acabar, aparecerá na tela do notebook a seguinte mensagem:

- Quero ouvir esta música novamente

- Estou pronto para associar uma emoção a esta música

Se vocês acharem que apenas uma escuta não foi o suficiente para vocês darem o seu julgamento emocional de forma segura, teclem na primeira opção. Então, esta mesma música tocará novamente e a tela do notebook se apagará. Se vocês acharem que a sua escuta foi o suficiente para dar o julgamento emocional de forma segura, então teclem na segunda opção, para que apareça a seguinte imagem na tela:
- Alegria
- Serenidade
- Tristeza
- Medo ou Raiva 
Então, com a ajuda do mouse, vocês deverão associar a música ouvida com alguma dessas emoções descritas na caixa de texto, clicando na emoção escolhida. Por exemplo: se vocês acharem que a música que vocês escutaram lhes causa uma sensação de Alegria, então teclem no ícone referente à emoção Alegria; se vocês acharam que a música que vocês escutaram lhes causa a sensação de Medo ou Raiva, então teclem no ícone referente às emoções Medo ou Raiva, e assim por diante. Quando vocês terminarem esta associação da música com a emoção escolhida, vocês deverão clicar na opção "confirmar", que se encontra logo abaixo da caixa de texto. Após vocês confirmarem as suas associações, aparecerá novamente a tela inicial, com os ícones enumerados de 1 a 30, porém, com o ícone da música que vocês escolheram para a tarefa de associação apagado, para que vocês não escolham a mesma música novamente. Então, novamente, vocês deverão escolher outro ícone, ouvir a música e associar a segunda música ouvida a alguma daquelas emoções. Atenção! A ordem em que as emoções Alegria, Medo ou Raiva, Serenidade e Tristeza aparecerão na caixa de textos estará embaralhada. Assim, pode ser que, para a primeira escuta, a emoção Alegria apareça em primeiro; para a segunda escuta, pode ser que a emoção Tristeza venha em primeiro; para a terceira escuta, pode ser que a emoção Alegria apareça em primeiro novamente, e assim por diante. Procedam da mesma forma com todas as outras músicas. Quando vocês fizerem a tarefa de associação das emoções com a última música, aparecerá a seguinte mensagem na tela do notebook:

\section{Muito obrigado por sua contribuição!}

Eu peço que vocês me comuniquem quando aparecer esta mensagem na tela, porque esta mensagem significa o término do experimento. Alguma dúvida? Caso tenham dúvidas, perguntem-me agora." 
Conforme o caso, o experimentador esclareceu as dúvidas dos participantes, ou mesmo, explicou, de forma sucinta, a tarefa novamente. Após o esclarecimento das dúvidas, foi dado início ao experimento.

Terminado o experimento, os participantes foram encaminhados, em silêncio, para fora da sala experimental, para o preenchimento dos questionários complementares.

Cada sessão experimental durou aproximadamente 25 minutos.

Análise dos dados: foi aplicado um teste Chi-Quadrado para verificar a porcentagem de respostas referentes aos julgamentos emocionais dos participantes em relação a cada trecho musical ouvido. Nos casos em que um mesmo trecho musical obteve uma porcentagem de respostas diferente entre os grupos (músicos e não músicos), foi feita uma correlação de Spearman para verificar qual emoção obteve o maior número de respostas dentro de cada grupo. Em uma análise mais aprofundada acerca das emoções associadas aos trechos musicais empregados neste estudo, os dados foram reorganizados da seguinte maneira: cada associação emocional dos participantes foi substituída por um valor numérico de 1 ou -1 , dependendo dos valores de arousal ou de valência afetiva encontrados. Assim, respostas emocionais de Alegria foram substituídas pelo par $(1,1)$, porque a Alegria pode ser entendida como sendo uma emoção com alto índice de arousal (1) e valência afetiva positiva (1); respostas emocionais de Serenidade foram substituídas pelo par $(-1,1)$, porque a Serenidade pode ser entendida uma emoção com baixo índice de arousal e valência afetiva positiva; da mesma forma, respostas da categoria emocional Medo/Raiva foram substituídas pelo par (1, -1), porque esta categoria emocional sugere alto índice de arousal e valência afetiva negativa; e, finalmente, respostas emocionais de Tristeza foram substituídas pelo par $(-1,-1)$, porque esta emoção sugere um baixo índice de arousal e valência afetiva negativa. (RUSSEL, 1980). Este tipo de análise possibilitou o cálculo de um valor numérico médio de arousal e de valência 
afetiva para cada um dos 30 trechos musicais empregados neste experimento, para ambos os grupos (músicos x não músicos). Ao final da análise, os valores numéricos encontrados foram distribuídos em um referencial cartesiano, elaborado a partir do modelo circumplexo de Russel (1980).

\subsubsection{RESULTADOS}

A Tabela 2 ilustra as porcentagens das emoções associadas por músicos e não músicos aos 30 trechos musicais do repertório erudito ocidental empregados. A maioria dos trechos musicais foi associada a uma emoção dominante (específica), para ambos os grupos (vinte e dois trechos musicais). Considerou-se uma emoção dominante quando uma mesma emoção, para determinado trecho musical, apontou índices de escolha maior que $50 \%$ pelos participantes. No entanto, alguns trechos não foram associados somente a uma única emoção (oito casos, em ambos os grupos).

De maneira geral, a Alegria foi a emoção associada com mais freqüência (com média percentual de 30\% para o grupo Músicos e 31\% para o grupo Não Músicos). A emoção Serenidade obteve média percentual de $29 \%$ para o grupo Músicos e $25 \%$ para o grupo Não Músicos. A emoção Tristeza obteve média percentual de $23 \%$ das associações para ambos os grupos. A categoria emocional Medo/Raiva obteve média percentual de $17 \%$ para o grupo Músicos e de apenas 21\% para o grupo Não Músicos.

O Teste Chi-Quadrado mostrou que das 30 músicas apresentadas para ambos os grupos de participantes (Músicos e Não músicos), apenas dois apresentaram diferenças significativas entre os julgamentos emocionais de um grupo e outro: as músicas número 5 e 17. Foi feita uma Correlação de Spearman para verificar qual emoção foi mais característica 
dentro de cada grupo, em relação a estas duas peças musicais. Assim, a música número 05 foi associada à Serenidade para ambos os grupos, porém, com índices diferentes sobre esta mesma emoção $\left[X^{2}(1)=12,522, p=0,006 ; C_{s}=-0,342 ; p=0,055\right]$. A música número 17 foi associada à Tristeza para o grupo Músicos e a Medo/Raiva para o grupo Não Músicos, $\left[X^{2}(2)\right.$ $\left.=9,6, p=0,008 ; C_{s}=-0,477 ; p=0,006\right]$.

Para todas as outras músicas apresentadas, não houve diferenças estatísticas significativas dos julgamentos emocionais entre os grupos (Músicos e Não músicos), ou seja, as emoções foram processadas de forma semelhante entre os dois grupos.

A Tabela 2 ilustra a porcentagem das associações emocionais dos trechos musicais apresentados aos participantes músicos e não músicos.

Tabela 2. Porcentagem de associações emocionais dos participantes (músicos e não músicos), em relação a cada trecho musical apresentado.

\begin{tabular}{|c|c|c|c|}
\hline & & Músicos & Não Músicos \\
\hline Música & Título & Associação emocional & Associação emocional \\
\hline 1 & Also sprach Zarathustra (Strauss) & Medo / Raiva (56,3\%) & Medo / Raiva (56,3\%) \\
\hline 2 & Waltz $n^{\circ} 03$ (Chopin) & Serenidade $(56,3 \%)$ & Serenidade (75\%) \\
\hline 4 & Violin Concerto Adágio (Brahms) & Serenidade $(75 \%)$ & Serenidade $(75 \%)$ \\
\hline 5 & Sonata A for Harpsichord (Scarlatti) & Serenidade $(100 \%)^{*}$ & Serenidade $(43,8 \%)^{*}$ \\
\hline 8 & Trio 2 for piano, violin and cello (Shostakovitch) & Tristeza $(62,5 \%)$ & Tristeza $(56,3 \%)$ \\
\hline 9 & Tristan, act 03 (Wagner) & TRI (68\%), MRV (18,8\%) e SER (12,5\%) & Tristeza (50\%) e Medo / Raiva (50\%) \\
\hline 10 & Symphony Bdur, Andante (Haydn) & Alegria $(87,5 \%)$ & Alegria $(87,5 \%)$ \\
\hline 11 & Poème Symphonique (Liszt) & TRI (56,3\%), SER (25\%) E MRV (18,8\%) & SER $(56,3 \%), \operatorname{TRI}(37,5 \%)$ E MRV $(6,3 \%)$ \\
\hline 12 & Gnossiènne $n^{\circ} 02$ (Satie) & Tristeza $(68,8 \%)$ & Tristeza $(81,3 \%)$ \\
\hline 17 & Tasso Lamento \& Triomfo (Liszt) & Tristeza $(56,3 \%)^{*}$ & Medo / Raiva $(87,5 \%)^{*}$ \\
\hline 18 & Tod and Verklärung 7' to 7'36 (Strauss) & Medo / Raiva $(87,5 \%)$ & Medo / Raiva $(93,8 \%)$ \\
\hline 19 & Violin Sonata (Bach) & SER (43,8\%), MRV (25\%), TRI (18,8\%) e ALE (12,5\%) & $\operatorname{ALE}(37,5 \%), \operatorname{MRV}(25 \%)$, SER $(18,8 \%)$ e TRI $(18,8 \%)$ \\
\hline 20 & Scherzo, presto - A truta (Schubert) & Alegria $(62,5 \%)$ & Alegria $(81,3 \%)$ \\
\hline 21 & Suíte française G - Sarabande (Bach) & Serenidade (50\%) e Tristeza (50\%) & Serenidade $(81,3 \%)$ e Tristeza $(18,3 \%)$ \\
\hline 22 & Duetto for two flutes in F, lamentabile (Bach) & Alegria $(62,5 \%)$ & Alegria $(62,5 \%)$ \\
\hline 23 & Trio for piano, violin and horn, moderato (Shostakovitch) & Alegria $(81,3 \%)$ & Alegria $(62,5 \%)$ \\
\hline 24 & Petrouchka (Stravinsky) & Alegria (75\%) & Alegria $(87,5 \%)$ \\
\hline 25 & Erwartung (Schöenberg) & Tristeza $(75 \%)$ & Tristeza $(68,8 \%)$ \\
\hline 26 & Trio 2 for violin, cello e piano - moderato (Shostakovitch) & Medo / Raiva (62,5\%) & Medo / Raiva $(56,3 \%)$ \\
\hline
\end{tabular}

* Indica diferenças estatísticas entre os grupos. 
A Figura 4 (a seguir) mostra os valores médios de arousal e de valência afetiva das associações emocionais de ambos os grupos, distribuídos no espaço semelhante ao modelo circumplexo da emoção de Russel (1980).
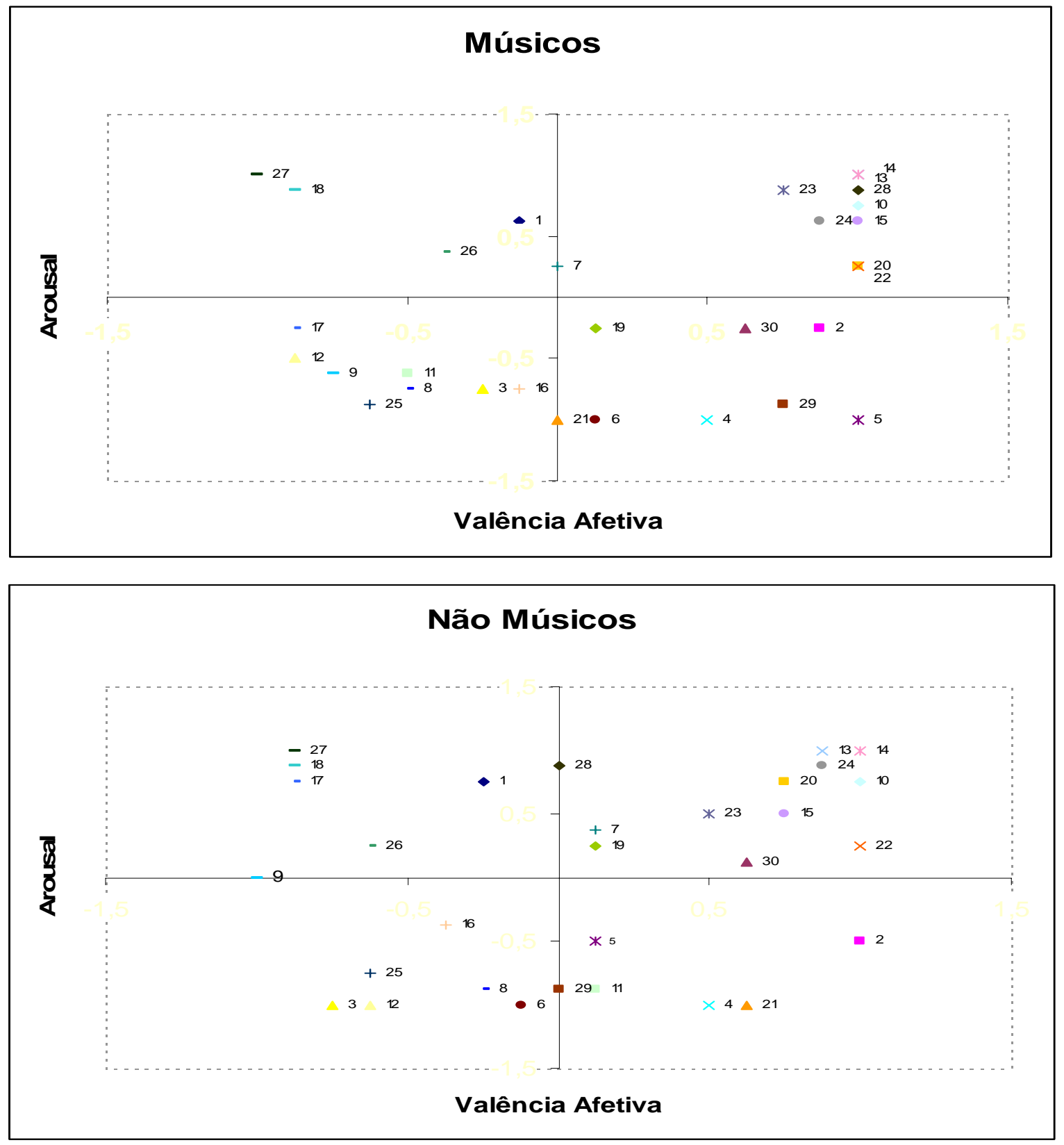

Figura 4. Níveis de arousal e valência afetiva das associações emocionais de músicos e não músicos em relação a cada trecho apresentado, distribuídos no referencial cartesiano elaborado a partir do modelo circumplexo de Russel (1980). Os trechos musicais podem ser identificados pelos números indicados no interior do gráfico. 
A Figura 4 ilustra as semelhanças das emoções desencadeadas pelos 30 trechos musicais selecionados para este estudo em músicos e não músicos. Os resultados nos permitem inferir que a música desencadeou emoções específicas nos ouvintes. Mais do que isto, os resultados também nos permitem inferir que as emoções específicas desencadeadas em músicos e não músicos foram processadas de forma parecida. Porém, a Figura 4 mostra que as respostas emocionais do grupo Músicos foram mais homogêneas em relação às respostas emocionais do grupo Não Músicos, ou seja, houve maior concordância de respostas sobre uma mesma emoção no primeiro grupo em relação ao segundo. Portanto, os agrupamentos das associações emocionais do grupo Músicos em relação aos trechos musicais desencadeadores de uma mesma emoção foram mais salientes do que os agrupamentos emocionais do grupo Não Músicos.

A análise do perfil emocional de cada trecho musical apresentado encontra-se a seguir.

Trecho musical 1 - Also sprach Zarathustra, Richard Strauss: foi associado à categoria emocional Medo/Raiva, com percentuais de 56,3\% para ambos os grupos; no entanto, índices emocionais de Alegria também foram associados a este trecho musical, com percentuais acima de $25 \%$ para ambos os grupos. No cartesiano, este trecho musical encontrou um espaço relacionado a índices de arousal positivo e valência afetiva negativa (quase neutra) nos ouvintes, para ambos os grupos.

Trecho musical 2 - Waltz, Op. 70, $n^{\circ}$ 03, Friéderick Chopin: foi associado à emoção Serenidade, com percentuais de $56,3 \%$ para o grupo Músicos e $75 \%$ para o grupo Não Músicos; no entanto, este trecho musical também obteve modestos percentuais de Alegria (37,5\% no grupo Músicos contra 25\% no grupo Não Músicos). No cartesiano, esta valsa de Chopin alcançou um espaço relacionado a índices de arousal negativo, porém, com índices bastante altos de valência afetiva positiva, para ambos os grupos. 
Trecho musical 3 - Piano Concerto Adágio, K 488, Wolfgang Mozart: foi associado à Tristeza, com percentuais de 56,3\% para o grupo Músicos e $87,5 \%$ para o grupo Não Músicos; no entanto, para o último grupo, obteve percentuais de Serenidade acima de $30 \%$. No cartesiano, este trecho musical encontrou um espaço relacionado a índices de arousal e de valência afetiva negativos (com índices maiores de valência negativa para o grupo Não Músicos).

Trecho musical 4 - Violin Concerto, Adágio, Johannes Brahms: foi associado predominantemente à Serenidade $(75 \%)$, com percentuais de Tristeza correspondentes a 25\% de associações para ambos os grupos. No cartesiano, este trecho musical encontrou o mesmo espaço entre grupos (relacionado a índices de arousal negativo e valência afetiva positiva).

Trecho musical 5 - Sonata (A) for Harpsichord, K 208, Domenico Scarlatti: foi um dos dois trechos musicais empregados neste estudo que apresentou diferenças significativas entre grupos, sendo, portanto, processado diferentemente entre músicos e não músicos. Assim, para o grupo Músicos, este trecho musical foi associado à Serenidade por todos os participantes (100\% de associações). No cartesiano, alcançou localização em um espaço relacionado a índices de arousal negativo e valência afetiva bastante positiva; para o grupo Não Músicos, este trecho musical não esteve relacionado a uma emoção específica, com percentuais de 43,8\% para Serenidade, 31\% para Tristeza, 12,5\% para Alegria e 12,5\% para Medo/Raiva. No cartesiano, esta sonata de Scarlatti encontrou um espaço relacionado a índices de arousal negativo e valência afetiva positiva (porém, quase neutra).

Trecho musical 6 - Träumerei, Op. 15, $n^{\circ}$ 07, R. Schumann: foi associado a percentuais das associações emocionais invertidos entre grupos: enquanto no grupo Músicos este trecho alcançou percentuais de Serenidade e Tristeza de 56,3\% e 43,8\%, respectivamente, no grupo Não Músicos, alcançou os mesmos índices de 56,3\% e 43,8\% de Tristeza e Serenidade, respectivamente. No cartesiano, este excerto musical encontrou espaços 
diferentes (porém próximos) entre grupos: para o grupo Músicos, o espaço esteve relacionado a índices de arousal negativo e pouca valência afetiva positiva (quase neutra), enquanto para o grupo Não Músicos, o espaço encontrado esteve relacionado a índices de arousal e valência afetiva negativos (o último índice, porém, quase neutro). Interessante observar que, apesar de este trecho musical se encontrar em espaço diferente no cartesiano entre grupos, não foram constatadas diferenças estatísticas significativas entre as associações emocionais relacionadas a este trecho, entre grupos.

Trecho musical 7 - Sonata for piano, $n^{\circ} 03,0 p .28$, Prokofièv: não foi associado a nenhuma emoção específica em ambos os grupos. No grupo Músicos, este trecho obteve índices percentuais de 31,3\% para Alegria e Medo/Raiva e percentuais de 18,8\% para Serenidade e Tristeza, encontrando, no cartesiano, um espaço relacionado a índices de arousal positivo e valência afetiva neutra (igual a zero); no grupo Não Músicos, obteve índices percentuais de 43,8\% para Medo/Raiva, 31,3\% para Serenidade e 25\% para Alegria, encontrando, no cartesiano, um espaço relacionado a índices de arousal e valência afetiva positivos (com o último índice quase neutro). Este foi mais um caso no qual espaços diferentes no cartesiano foram encontrados, entre os grupos, porém, sem diferenças estatísticas significativas.

Trecho musical 8: Trio 02 for piano, violin and cello (largo), D. Shostakovitch: foi associado à Tristeza por ambos os grupos (62,5\% para o grupo Músicos contra 56,3\% para o grupo Não Músicos), com índices expressivos de Serenidade (35\% para o grupo Músicos contra 37,5\% para o grupo Não Músicos). No cartesiano, este trecho musical encontrou um espaço relacionado a índices de arousal e valência afetiva negativos para ambos os grupos.

Trecho musical 9: Tristan, Act 3, Wagner: foi associado predominantemente à Tristeza para o grupo Músicos (68,8\%) e tanto à Tristeza quanto a Medo/Raiva para o grupo Não Músicos (50\% para cada categoria emocional). No cartesiano, ocupou um espaço 
referente a índices de arousal e valência afetiva negativos para o grupo Músicos e um espaço referente a índices de arousal neutro (igual a zero) e valência afetiva negativa. Apesar de ocupar diferentes espaços no cartesiano, não foram encontradas diferenças estatísticas sobre as associações emocionais deste trecho musical entre grupos.

Trecho musical 10: Symphony Bdur, Hob 1, 105, Andante, J. Haydn: foi associado de forma idêntica entre os grupos, cujas respostas emocionais foram direcionadas predominantemente a Alegria (87,5\%), encontrando, no cartesiano, um espaço referente a índices de arousal e valência afetiva positivos para ambos os grupos.

Trecho musical 11: Poème Symphonique, F. Liszt: foi associado de forma diferente, entre grupos, tendo sido associado predominantemente à Tristeza para o grupo Músicos (56,3\%) e com 25\% das associações direcionadas à Serenidade e 18,8\% das associações direcionadas à categoria emocional Medo/Raiva. No cartesiano, para o grupo Músicos, encontrou um espaço referente a índices de arousal e de valência afetiva negativos; para o grupo Não Músicos, este trecho musical foi associado predominantemente à Serenidade (56,3\%), com 37,5\% das associações emocionais direcionadas à Tristeza e apenas $6,3 \%$ das associações emocionais direcionadas à categoria emocional Medo/Raiva. No cartesiano, encontrou um espaço referente a índices de arousal negativo e valência afetiva positiva. Apesar das diferenças entre a porcentagem das associações predominantes para cada grupo de participantes, não foram encontradas diferenças estatísticas sobre estes números.

Trecho musical 12: Gnossiènne $n^{\circ}$ 02, Érik Satie: foi associado predominantemente à Tristeza para ambos os grupos, com porcentagens equivalentes a 68,8\% para o grupo Músicos e 81,3\% para o grupo Não Músicos; no cartesiano, este trecho musical ocupou um espaço referente a índices de arousal e valência afetiva negativos, para ambos os grupos.

Trecho musical 13: Hungarian Rapsody $n^{\circ}$ 02, F. Liszt: foi associado predominantemente à Alegria, para ambos os grupos $(100 \%$ das associações para o grupo 
Músicos e 93,8\% das associações para o grupo Não Músicos). No cartesiano, este trecho musical ocupou um espaço referente a altos índices de arousal e de valência afetiva positivos para ambos os grupos.

Trecho musical 14: That certain feeling, G. Gershwin: foi o único trecho musical associado a uma única emoção com 100\% das associações para ambos os grupos (no caso, a emoção Alegria). No cartesiano, este rag-time de Gershwin ocupou um espaço referente aos maiores índices de arousal e de valência afetiva positivos possíveis, encontrados neste estudo, para ambos os grupos.

Trecho musical 15: Italian Symphony, $1^{\text {st }}$ movement, F.Mendelsohn: assim como o trecho musical $n^{\circ} 13$, foi associado predominantemente à Alegria, para ambos os grupos (no entanto, com 81,3\% das associações para o grupo Músicos e $68,8 \%$ das associações para o grupo Não Músicos). No cartesiano, este trecho musical ocupou um espaço referente a altos índices de arousal e de valência afetiva positivos para ambos os grupos.

Trecho musical 16: Prèlude $n^{\circ}$ 24, Chopin: foi associado de forma distinta entre grupos. Para o grupo Músicos, este trecho obteve percentuais de 43,8\% de associações emocionais à Serenidade e à Tristeza, com apenas 12,5\% das associações à categoria emocional Medo/Raiva; para o grupo Não Músicos, este trecho também obteve percentuais de 43,8\% de associações emocionais para Tristeza, mas com 25\% das associações emocionais para Serenidade e Medo/Raiva, com apenas 6,3\% das associações emocionais à Alegria. No cartesiano, para ambos os grupos, este trecho musical ocupou um espaço referente a índices de arousal e valência afetiva negativos (com maiores índices de arousal negativo e de valência afetiva positiva para o grupo Não Músicos.

Trecho musical 17: Tasso Lamento e Triomfo, F. Liszt: foi um dos dois trechos musicais empregados neste estudo que apresentou diferenças significativas entre grupos, sendo, portanto, processado diferentemente entre músicos e não músicos. Assim, para o grupo 
Músicos, este trecho musical foi associado à Tristeza por 56,3\% dos participantes, com percentuais de 37,5\% de associações à categoria emocional Medo/Raiva, tendo encontrado um espaço no cartesiano referente a índices de valência afetiva negativos e arousal também negativo (embora quase neutro); para o grupo Não Músicos, este trecho musical foi associado a Medo/Raiva por $87,5 \%$ dos participantes, tendo encontrado um espaço no cartesiano referente a índices de arousal positivo e valência afetiva positiva.

Trecho musical 18: Tod und Verklärung, 7’ a 7’36, R. Strauss: foi associado predominantemente à categoria emocional Medo/Raiva para ambos os grupos (com 87,5\% das associações para o grupo Músicos e 93,8\% das associações para o grupo Não Músicos). No cartesiano, este trecho musical ocupou um espaço referente a índices de arousal positivo e de valência afetiva negativa, para ambos os grupos.

Trecho musical 19: Violin Sonata, J. S. Bach: não foi associado a uma categoria emocional específica para nenhum dos dois grupos. Para o grupo Músicos, obteve porcentagens de 43,8\% para Serenidade, 25\% para Medo/ Raiva, 18,8\% para Tristeza e 12,5\% para Alegria; no cartesiano, este trecho musical encontrou um espaço referente a índices de arousal negativo e valência afetiva positiva (ambos os índices bastante baixos); para o grupo Não Músicos, obteve porcentagens de 37,5\% para Alegria, 25\% para Medo/Raiva e 18,8\% para Serenidade e Tristeza; no cartesiano, este trecho musical encontrou um espaço referente a índices de arousal e valência afetiva positivos (ambos os índices, no entanto, também bastante baixos). Apesar de este trecho musical ter alcançado quadrantes diferentes no cartesiano, não foram encontradas diferenças estatísticas sobre as associações emocionais entre grupos.

Trecho musical 20: Scherzo, presto - A truta, F. Schubert: foi associado predominantemente à Alegria e Serenidade pelo grupo Músicos $(62,5 \%$ e 37,5\% das associações, respectivamente) e somente à Alegria pelo grupo Não Músicos $(81,3 \%$ das 
associações). No cartesiano, este trecho musical ocupou uma posição referente a índices de arousal e valência afetiva positivos, para ambos os grupos, com índices de arousal mais altos para o grupo Não Músicos e índices mais altos de valência afetiva para o grupo Músicos; apesar de diferenças nas porcentagens e nos índices de arousal e valência afetiva, não foram encontradas diferenças estatísticas sobre as associações emocionais entre grupos.

Trecho musical 21: Suíte française, G - Sarabande, J. S. Bach: foi associado às emoções Serenidade e Tristeza para o grupo Músicos $(50 \%$ das associações para cada categoria) e predominantemente à Serenidade para o grupo Não Músicos $(81,3 \%$ das associações emocionais para esta categoria). No cartesiano, este trecho musical ocupou uma posição referente a índices de arousal negativo e valência afetiva neutra para o grupo Músicos e uma posição referente a índices de arousal negativo e valência afetiva positiva para o grupo Não Músicos, não sendo observadas diferenças estatísticas entre as porcentagens encontradas sobre as associações emocionais entre grupos.

Trecho musical 22: Duetto for two flutes in F, Lamentabile, W. F. Bach: em ambos os grupos, este trecho musical foi associado às emoções Alegria e Serenidade $(62,5 \% \mathrm{e}$ 37,5\% das associações, respectivamente), alcançando um espaço referente a baixos índices de arousal positivo e altos índices de valência afetiva positiva, no cartesiano.

Trecho musical 23: Trio for piano, violin and horn, $2^{\text {nd }}$ movement, J. Brahms: foi associado predominantemente à emoção Alegria em ambos os grupos $(81,3 \%$ das associações para o grupo Músicos e 62,5\% das associações para o grupo Não Músicos), tendo alcançado, no cartesiano, um espaço referente a índices de arousal e valência afetiva positivos para ambos os grupos.

Trecho musical 24: Petrouchka, I. Stravinsky: assim como o trecho musical anterior, foi associado predominantemente à emoção Alegria em ambos os grupos (no entanto, com $75 \%$ das associações para o grupo Músicos e $87,5 \%$ das associações para o 
grupo Não Músicos), tendo alcançado, no cartesiano, um espaço referente a índices de arousal e valência afetiva positivos para ambos os grupos.

Trecho musical 25: Erwartung, A. Schöenberg: foi predominantemente associado à emoção Tristeza em ambos os grupos (75\% das associações para o grupo Músicos e $68,8 \%$ das associações para o grupo Não Músicos), tendo alcançado, no cartesiano, um espaço referente a índices de arousal e valência afetiva negativos para ambos os grupos.

Trecho musical 26: Trio 2 for violin, cello and piano, moderato, D. Shostakovitch: foi associado predominantemente à categoria emocional Medo/Raiva (62,5\% das associações para o grupo Músicos e 56,3\% das associações para o grupo Não Músicos); no entanto, no primeiro grupo, $25 \%$ das associações emocionais foram direcionadas à Serenidade, enquanto, no segundo, esta mesma porcentagem esteve associada à Tristeza; entretanto, no cartesiano, este trecho musical alcançou posições no mesmo quadrante, entre grupos (espaço referente a índices de arousal positivo e valência afetiva negativa).

Trecho musical 27: Totentanz, F. Liszt: foi bastante associado à categoria emocional Medo/Raiva em ambos os grupos, com 100\% de associações no grupo Músicos e 93,8\% de associações no grupo Não Músicos; no cartesiano, ocupou um espaço referente a altos índices de arousal positivo e de valência afetiva negativa.

Trecho musical 28: O tambor dos granadeiros, L. Chapí: foi associado predominantemente à emoção Alegria em ambos os grupos, com 93,8\% das associações dos músicos e 75\% das associações dos não músicos (no último grupo, no entanto, índices de $18,8 \%$ foram encontrados para a emoção Medo/Raiva). Por causa dessa diferença entre as porcentagens encontradas entre os grupos, este trecho ocupou espaços diferentes no cartesiano: índices de arousal e valência afetiva positivos para o grupo Músicos e índices de arousal positivo e valência afetiva neutra para o grupo Não Músicos; no entanto, apesar de 
existirem diferenças entre os percentuais de associações entre grupos, não foram encontradas diferenças estatísticas sobre os mesmos.

Trecho musical 29: Violin romance, L. V. Beethoven: foi associado predominantemente à emoção Serenidade para o grupo Músicos (81,3\% das associações), tendo encontrado, no cartesiano, um espaço referente a altos índices de arousal negativo e valência afetiva positiva; no grupo Não Músicos, não foi associado a uma emoção específica (50\% das associações direcionadas à Tristeza e 43,8\% das associações direcionadas à Serenidade), tendo encontrado, no cartesiano, um espaço referente a índices de arousal negativo e valência afetiva neutra (igual a zero); apesar de índices diferentes, não foram encontradas diferenças estatísticas sobre as associações emocionais entre grupos.

Trecho musical 30: Valse in E minor - vivace (póstuma), F. Chopin: no grupo Músicos, foi associado predominantemente às emoções Serenidade (50\% das associações) e Alegria (31,3\% das associações), tendo ocupado, no cartesiano, um espaço referente a baixos índices de arousal negativo e valência afetiva positiva; inversamente ao grupo Músicos, este trecho musical foi associado às emoções Alegria (43,8\% de associações) e Serenidade (37,5\% das associações), tendo ocupado, no cartesiano, um espaço referente a baixos índices de arousal positivo e valência afetiva positiva; apesar de porcentagens inversas e de terem ocupado espaços diferentes no cartesiano, não foram encontradas diferenças estatísticas sobre as associações emocionais deste trecho musical entre grupos.

\subsubsection{DISCUSSÃO}

O presente experimento teve como objetivo mensurar respostas emocionais de músicos e não músicos a trechos musicais do repertório erudito ocidental. Este assunto já foi 
abordado por diversos autores (HEVNER, 1935, 1936; ROBAZZA; MACALUSO; D’URSO, 1994; JUSLIN; SLOBODA, 2001; JUSLIN; LAUKKA, 2004; BIGAND et al., 2005). De maneira geral, os dados aqui obtidos foram coerentes com os dados obtidos nestes estudos: alguns trechos musicais do repertório erudito ocidental desencadearam emoções específicas em ouvintes ocidentais (portanto, da mesma cultura), enquanto outros trechos não desencadearam uma única emoção específica nos mesmos ouvintes. Essas diferenças apareceram tanto em músicos quanto em não músicos: 22 trechos musicais empregados foram associados a uma única emoção e 8 trechos musicais não foram associados a uma única emoção específica, em ambos os grupos. Essa não associação pode ter ocorrido devido a alguns fatores.

O primeiro fator pode ter sido determinado pelo tipo do teste empregado no presente estudo. Bigand et al. (2005), em seu experimento, verificaram respostas emocionais de músicos e não músicos a trechos musicais do repertório erudito ocidental. Para isso, os autores elaboraram uma tarefa experimental que consistia em reagrupar os trechos musicais característicos de uma mesma emoção, definindo assim categorias emocionais sem recorrer à linguagem verbal, abrindo mão de um léxico emocional, que se sabe variável em função do nível de conhecimento musical e das aptidões verbais de cada um. Duas semanas após essa "categorização livre", os mesmos participantes refizeram a tarefa com os mesmos trechos musicais. Apesar de os resultados indicarem as categorizações emocionais Alegria, Tristeza, Serenidade, Medo e Raiva como sendo os léxicos emocionais mais freqüentemente encontrados, outros léxicos como Ternura, Nostalgia e Curiosidade também foram encontrados. Neste estudo, os questionários aplicados após o experimento indicaram que alguns participantes tiveram dúvidas para associar certos trechos musicais a uma única emoção, alegando outros léxicos não empregados no estudo (como Melancolia, Paixão, Amor, entre outros). O uso de apenas quatro possibilidades de escolha (Alegria, Tristeza, Serenidade, Medo /Raiva) pode explicar o fato de alguns trechos musicais não terem sido associados a uma única categoria emocional, uma vez que 
alguns trechos musicais poderiam ter sido associados a outras categorias emocionais. Além disso, Juslin e Laukka (2004) sugerem certas estruturas musicais que freqüentemente estão associadas com as emoções musicais de base, por exemplo: músicas executadas em andamentos rápidos, com pouca variabilidade de andamento, em modo maior, com harmonia simples e consonante, com pouca variação de dinâmica, com melodia ascendente e com contorno melódico acentuado (entre outras), normalmente serão associadas à Alegria. Da mesma forma, há uma série de outras estruturas musicais também associadas às outras emoções musicais de base, como Tristeza, Serenidade, Medo/Raiva.

Outra hipótese a ser considerada para explicar o fato de alguns trechos musicais não terem sido associados a uma única emoção, no presente estudo, é a de que os trechos musicais não associados a uma emoção específica tinham algumas estruturas musicais encontradas por Juslin e Laukka (2004) que pertenciam a diferentes categorias emocionais. Por exemplo: o trecho musical 30 (Valse in E minor, de F. Chopin), que não foi associado a nenhuma emoção específica por ambos os grupos, tinha um andamento rápido (estrutura considerada pelos autores como sendo associada predominantemente à Alegria), estava em modo menor (estrutura considerada pelos autores como sendo associada predominantemente à Tristeza), articulações de staccato (estrutura considerada pelos autores como sendo associada predominantemente à Raiva) e súbitos ataques nas notas da melodia (estrutura considerada pelos autores como sendo associada predominantemente à emoção Medo). A estrutura deste trecho musical, portanto, misturava elementos estruturais de uma categoria emocional sugerida por Juslin e Laukka (2004) com outras categorias. Esta mistura de elementos estruturais, envolvendo categorias emocionais diferentes (JUSLIN; LAUKKA, 2004) dentro um mesmo trecho musical, pode explicar a ambigüidade das respostas emocionais para estes trechos.

Outra hipótese a ser pensada, para explicar a "ambigüidade emocional" das respostas dos participantes deste estudo a determinados trechos musicais, pode estar centrada 
nas bruscas mudanças de estruturas harmônica, melódica ou rítmica ocorridas em alguns trechos musicais empregados no presente estudo. Tais mudanças estruturais podem ter feito com que um mesmo trecho musical tenha iniciado com características estruturais relacionadas a uma categoria emocional (Alegria, por exemplo), mas, no decorrer de sua execução, alterações bruscas referentes a estas características estruturais podem ter ocorrido, a ponto de influenciar os participantes a associar este trecho musical a outra categoria emocional (Medo/Raiva, por exemplo). Observe-se que o trecho musical 11 (Poème Symphonique, de Liszt), também não associado a nenhuma emoção específica por ambos os grupos, informava aos ouvintes dois períodos diferentes: ele iniciava com uma simples nota executada por um naipe de cordas, cujo caminho melódico percorria uma escala pentatônica. Estas características estruturais são predominantemente associadas à Alegria (JUSLIN; LAUKKA, 2004); porém, a partir do décimo quarto segundo de sua execução, esta estrutura original era alterada: um naipe de madeiras passava a solar a melodia, a partir de um ponto melódico que era constituído por um acorde dissonante, que se resolvia em um acorde menor com sexta (características predominantemente associadas a Medo/Raiva). Portanto, este trecho musical informava ao participante certa ambigüidade entre um período (anterior ao décimo quarto segundo de execução) e outro (após o décimo quarto segundo de execução). Assim, o participante pode ter tido dúvidas na escolha da emoção a ser associada em relação a este trecho musical. Para o trecho musical em questão, se a resposta emocional tivesse sido dada em relação ao primeiro período do evento, então provavelmente a categoria emocional associada a este evento seria a Alegria; no entanto, se a resposta emocional tivesse sido dada em relação ao segundo período do evento, provavelmente a categoria emocional associada seria Medo/Raiva.

Portanto, o emprego do teste de escolha forçada, a presença de elementos estruturais referentes a categorias emocionais distintas em um mesmo trecho musical e a 
presença de mudanças de ordem estrutural no decorrer de alguns eventos musicais podem ter sido os fatores responsáveis pela não associação de alguns trechos musicais a uma única emoção específica pelos ouvintes no presente estudo.

Outra questão investigada pelo presente estudo é a influência do potencial da expertise musical sobre respostas emocionais à música. A literatura tem mostrado provas de que músicos processam a informação musical de forma mais "refinada" que os não músicos (WATERMAN, 1996; KOELSCH et al., 2000; SCHERER; ZENTNER, 2001; GALVÃO, 2006). No entanto, os estudos acerca desta questão têm mostrado que não músicos respondem a mudanças sutis na estrutura musical de forma comparável aos músicos (BIGAND; POULIN-CHARRONNAT, no prelo). Assim, se considerarmos que a resposta emocional à música está, pelo menos em parte, enraizada no processamento das estruturas musicais e não na experiência pessoal de cada um (BIGAND et al., 2005), uma hipótese que pode explicar o processamento da informação musical dos músicos como sendo mais "refinado" do que o processamento da informação emocional dos não músicos é a de que o primeiro grupo pode ter identificado as emoções desencadeadas durante as escutas musicais de forma mais rápida do que o segundo grupo. Isto pelo fato de lidarem com a experiência musical de forma mais analítica, decorrente do tempo de estudo (aprendizagem) musical. Em outras palavras: músicos parecem estar mais treinados para tarefas relacionadas à percepção de emoções desencadeadas durante uma escuta musical. E isto ocorreu no presente estudo: ambos os grupos foram respondendo de forma emocional coerente aos trechos musicais empregados. Uma prova disso é que dos 30 trechos musicais empregados no presente estudo, 27 obtiveram respostas emocionais semelhantes entre os grupos. Porém, de forma geral, houve mais consistência nas respostas emocionais dos músicos em relação às respostas emocionais dos não músicos. Isso significa que houve mais respostas emocionais relacionadas a um mesmo trecho musical para o grupo Músicos do que para o grupo Não Músicos. Este dado é coerente 
com outros estudos sobre a análise da expertise musical sobre respostas emocionais (BIGAND et al., 2005; BIGAND; FILIPIC; LALITTE, no prelo).

Finalmente, os dados deste estudo nos permitem identificar algumas conclusões acerca dos processos psicológicos que permeiam o processamento das emoções musicais de trechos musicais do repertório erudito ocidental, durante uma escuta musical, em sujeitos ocidentais. Primeiro, assim como no estudo realizado por Bigand et al. (2005), os resultados deste estudo sugerem que as emoções musicais dependem mais da cognição dos elementos da estrutura musical de uma obra do que da história pessoal de cada um. Segundo, a maioria dos trechos musicais empregados desencadeou uma única emoção específica nos ouvintes; porém, alguns destes trechos musicais não desencadearam uma única emoção durante a escuta. Esta não associação pode depender de alguns fatores, como o tipo de teste empregado para mensurar as emoções musicais, o fato de alguns trechos musicais terem elementos estruturais que sugerem associações a categorias emocionais distintas (Alegria e Tristeza, ao mesmo tempo, por exemplo) e a presença de mudanças bruscas de ordem estrutural no decorrer do evento musical, que podem levar a associações emocionais ambíguas pelos ouvintes. Terceiro, apesar de o teste de escolha forçada ter limitado o número de categorias emocionais a serem escolhidas pelos ouvintes, este teste foi eficiente para categorizar emocionalmente alguns trechos musicais apropriados para serem submetidos a tarefas de associação temporal (Experimento II).

A próxima etapa do presente estudo consistiu em selecionar os trechos musicais que obtiveram a maior porcentagem de associações emocionais a uma única emoção específica, em ambos os grupos deste experimento, e submetê-los a tarefas de associações temporais, no intuito de verificar a influência das emoções percebidas durante uma escuta musical na percepção temporal de músicos e não músicos. 
Experimento I 


\subsubsection{INTRODUÇÃO}

Existem, na literatura científica, alguns estudos que procuram verificar a influência de estados emocionais sobre a percepção subjetiva de tempo em humanos (ANGRILLI, 1997; DROIT-VOLET; TOURRET; WEARDEN, 2004; GIL; NIEDENTHAL; DROIT-VOLET, 2007). No entanto, ainda não se sabe ao certo se uma atmosfera emocional pode influenciar de forma decisiva a percepção temporal de um evento. Enquanto alguns dados sugerem que adultos superestimam durações de imagens que sugerem um alto conteúdo emocional em relação às imagens neutras (GIBBON et al., 1984), outros sugerem que a percepção de uma única emoção (no caso, a Raiva) é responsável por superestimações temporais (DROIT-VOLET; MECK, 2007). Em alguns estudos, ainda, ficou demonstrado que o aumento do arousal em situações de valência afetiva negativa (provocado por imagens de ferimentos envolvendo sangue humano, por exemplo) foi responsável pela superestimação do tempo em relação a eventos de valência afetiva neutra, como imagens de objetos domésticos ou eventos de valência afetiva positiva, como imagens de filhote de animais ou humanos recém-nascidos, por exemplo. Além disso, em contextos envolvendo baixos índices de arousal, figuras que sugeriam valência afetiva negativa foram subestimadas e figuras que sugeriam valência afetiva positiva foram superestimadas (ANGRILLI et al., 1997).

Até onde sabemos, não existem ainda, na literatura, estudos que procurem verificar sistematicamente a influência das emoções na percepção temporal de humanos que utilizam a música como evento. Sendo um estímulo acústico indutor de uma grande variedade de respostas emocionais nos ouvintes (BIGAND et al., 2005), a música pode, portanto, ser utilizada como o estímulo adequado para que estudos sobre a influência das emoções sobre a percepção temporal sejam realizados em sujeitos humanos. 
Considerando o fato de que músicos processem as informações musicais de forma mais "refinada" que os não músicos (WATERMAN, 1996; KOELSCH et al., 2000; SCHERER; ZENTNER, 2001; GALVÃO, 2006) e de que existem evidências de que as atmosferas emocionais distintas possam influenciar a percepção temporal humana (BIGAND et al., 2005), é possível supor que haja um efeito distinto, se compararmos músicos e não músicos, em relação ao processamento das emoções desencadeadas durante uma escuta musical sobre a percepção temporal.

Assim, este experimento teve como objetivos agrupar os trechos musicais do repertório erudito ocidental, associados a uma mesma emoção, utilizados no experimento I, e submetê-los a tarefas relacionadas ao processamento temporal, no intuito de verificar se o tempo subjetivo (de músicos e não músicos) é afetado por algum componente emocional presente durante a escuta musical.

\subsubsection{MÉTODO}

Participantes: a amostra de participantes foi dividida em dois grupos: 20 estudantes de um curso de graduação em Música, que tinham pelo menos seis anos de experiência de estudo sistematizado de algum instrumento musical oferecido pelo curso: piano, violão, violino, viola, violoncelo, contrabaixo, flauta transversal, clarineta, trombone ou saxofone (classificados neste estudo como músicos) e 20 participantes que não tinham nenhuma experiência em estudo de música (classificados neste estudo como não músicos). Os participantes tinham entre 18 e 31 anos de idade (média $=26,2$ anos). Nenhum participante deste experimento teve participação no Experimento I. 
Equipamento e material: os equipamentos e materiais utilizados foram semelhantes aos equipamentos e materiais utilizados no Experimento I. No entanto, as músicas escolhidas para este experimento foram os três trechos musicais mais representativos de cada categoria emocional avaliada (Alegria, Tristeza, Serenidade, Medo/Raiva), a partir dos resultados da análise de dados do Experimento I. A Tabela 3 ilustra as músicas selecionadas, a emoção que cada uma delas representa e a nova nomenclatura utilizada para a análise de dados.

Tabela 03. Associação das emoções específicas analisadas aos trechos musicais utilizados no Experimento I e a nova nomenclatura de cada trecho musical que será utilizada neste experimento.

\begin{tabular}{|c|c|c|c|}
\hline \multicolumn{2}{|c|}{ Músicas } & Emoções & Nova Nomenclatura \\
\hline Número & Título & & \\
\hline & & & \\
\hline 10 & Symphony Bdur, Hob 1 105, Andante - Haydn & Alegria & ALE 01 \\
\hline 13 & Hungarian Rapsody n 02 - Liszt & Alegria & ALE 02 \\
\hline 14 & That certain feeling - Gershwin & Alegria & ALE 03 \\
\hline 2 & Waltz, Op. 70, $\mathrm{n}^{\circ}$ 03 - Chopin & Serenidade & SER 01 \\
\hline 4 & Violin Concerto Adágio - Brahms & Serenidade & SER 02 \\
\hline 29 & Violin Romance - Beethoven & Serenidade & SER 03 \\
\hline 3 & Piano Concerto Adágio, K 488 - Mozart & Tristeza & TRI 01 \\
\hline 12 & Gnossienne $\mathrm{n}^{\circ}$ 02 - Satie & Tristeza & TRI 02 \\
\hline 25 & Erwartung - Shöenberg & Tristeza & TRI 03 \\
\hline 18 & Tod and Verklärung, 7' - 7'30 - R. Strauss & Medo / Raiva & MRV 01 \\
\hline 26 & Trio 2 for violin, cello and piano, moderato - Shostakovitch & Medo / Raiva & MRV 02 \\
\hline 27 & Totentanz - Liszt & Medo / Raiva & MRV 03 \\
\hline
\end{tabular}

Procedimento: assim como no Experimento I, este experimento foi realizado com a presença de dois participantes por vez na sala experimental. Esta medida também foi usada para acelerar o processo de coleta de dados, uma vez que um número muito grande de participantes foi necessário para o desenvolvimento desta pesquisa. Os participantes foram conduzidos pelo experimentador até a sala experimental. Foram dados 30 segundos para acomodação à situação experimental. O experimentador, então, mostrou a cada participante o Termo de Consentimento referente ao Comitê de Ética e Pesquisa. Logo em seguida, então, o experimentador disse: "Vocês vão dar uma contribuição para nossos estudos. Para isso, eu vou pedir que vocês executem pequenas tarefas, uma de cada vez. Peço que vocês escutem 
todo o procedimento antes do início do experimento". Após o consentimento, o experimentador então prosseguia com as instruções: "Vocês vão realizar tarefas relacionadas a comparações temporais de diversos sons. Primeiramente, vocês deverão colocar este fone de ouvido e acomodá-lo adequadamente. As tarefas serão realizadas nestes notebooks, através de três arquivos do programa Power Point. O experimento é auto-explicativo. Peço que vocês leiam com bastante atenção cada tarefa a ser realizada. Em caso de dúvidas surgidas durante o experimento, façam-me um sinal, que eu as explico imediatamente".

As tarefas realizadas pelos participantes foram divididas em três subtarefas.

Na primeira subtarefa, o Power Point mostrava a seguinte tela para os participantes:

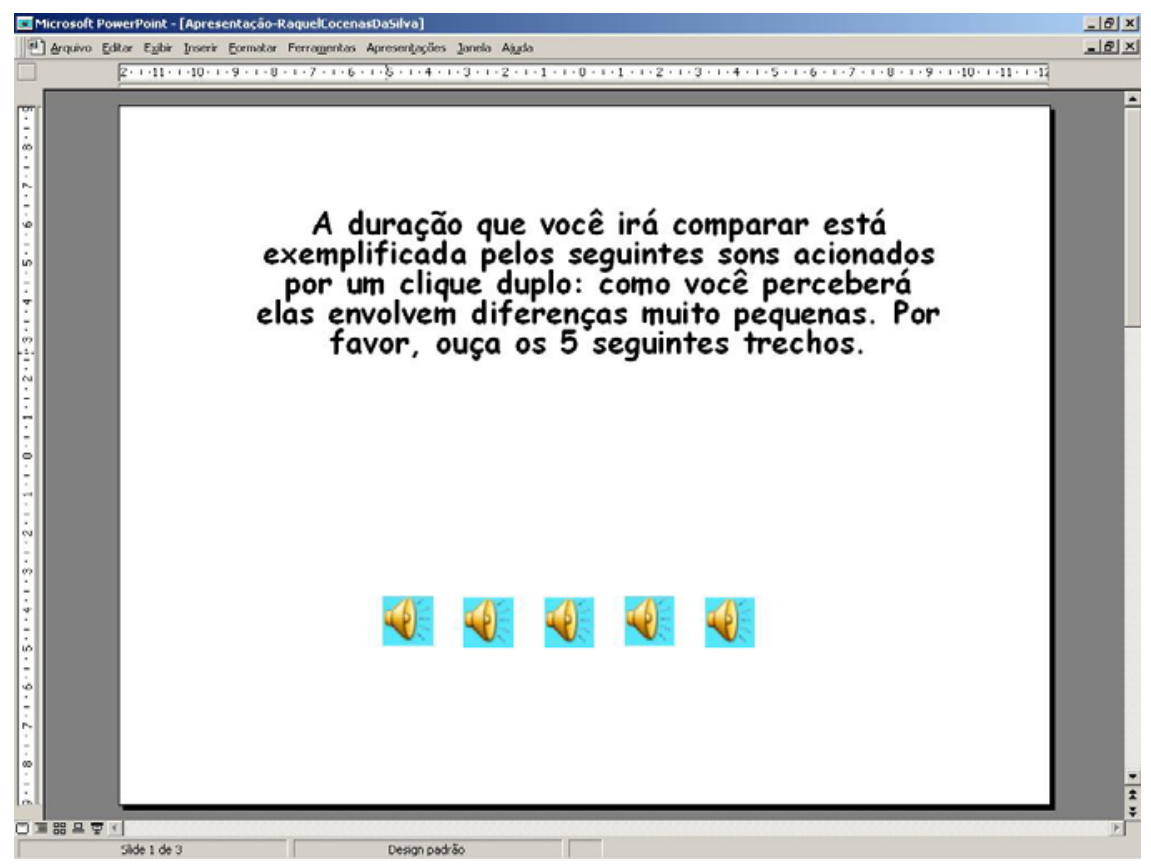

Os cinco alto-falantes localizados na parte inferior da tela correspondiam a durações sonoras de 16,18, 20, 22 e 24 segundos, respectivamente. Os participantes não sabiam o tempo de cada duração sonora. O timbre escolhido para as durações foi o de tom 
puro, com $50 \mathrm{~dB}$ de freqüência (confortável para os participantes). Os participantes deveriam então, nesta tarefa, apenas escutar as cinco durações, atentamente. Foi pedido que os participantes não marcassem o tempo, através de contagem, pulsação, batida de pés ou mãos, ou qualquer outra forma de marcação temporal.

Quando o participante terminava de realizar a primeira subtarefa, então, o Power Point mostrava a seguinte tela:

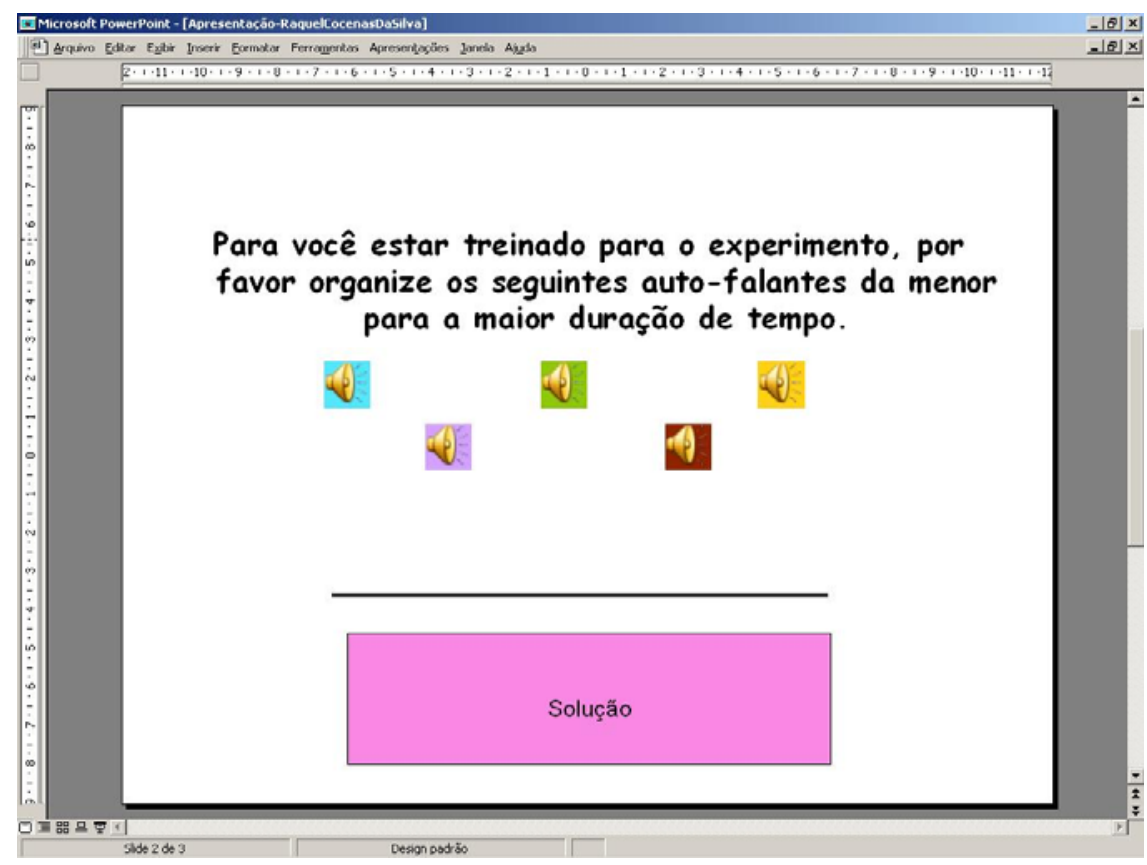

Os cinco alto-falantes coloridos, localizados abaixo das instruções, se referiam às mesmas durações apresentadas na subtarefa anterior. Porém, agora, estas durações não eram apresentadas em ordem crescente para os participantes: elas estavam em ordem aleatória. Os participantes não sabiam qual era a duração sonora de cada alto-falante. Os participantes deveriam, com a ajuda do mouse, arrastar os alto-falantes coloridos (que estavam em ordem embaralhada de duração) para a linha horizontal (localizada logo abaixo dos alto-falantes) e organizá-los, da menor para a maior duração. 
A caixa de textos cor-de-rosa, com a palavra "solução" localizada na parte inferior da tela, se, arrastada com o mouse, permitia que os participantes verificassem se a ordem por eles elaborada correspondia à ordem correta das durações, da menor para a maior. No entanto, a solução só podia ser verificada após a organização dos alto-falantes coloridos na linha horizontal. Assim, não tinha como os participantes verificarem a solução da tarefa antes de organizá-los na linha horizontal.

Antes do início desta subtarefa, era dito aos participantes que não marcassem o tempo das durações através de contagem, pulsação, batida de pés ou mãos, ou qualquer outra forma de marcação temporal.

Terminada a segunda subtarefa, então, o Power Point mostrava a seguinte tela:

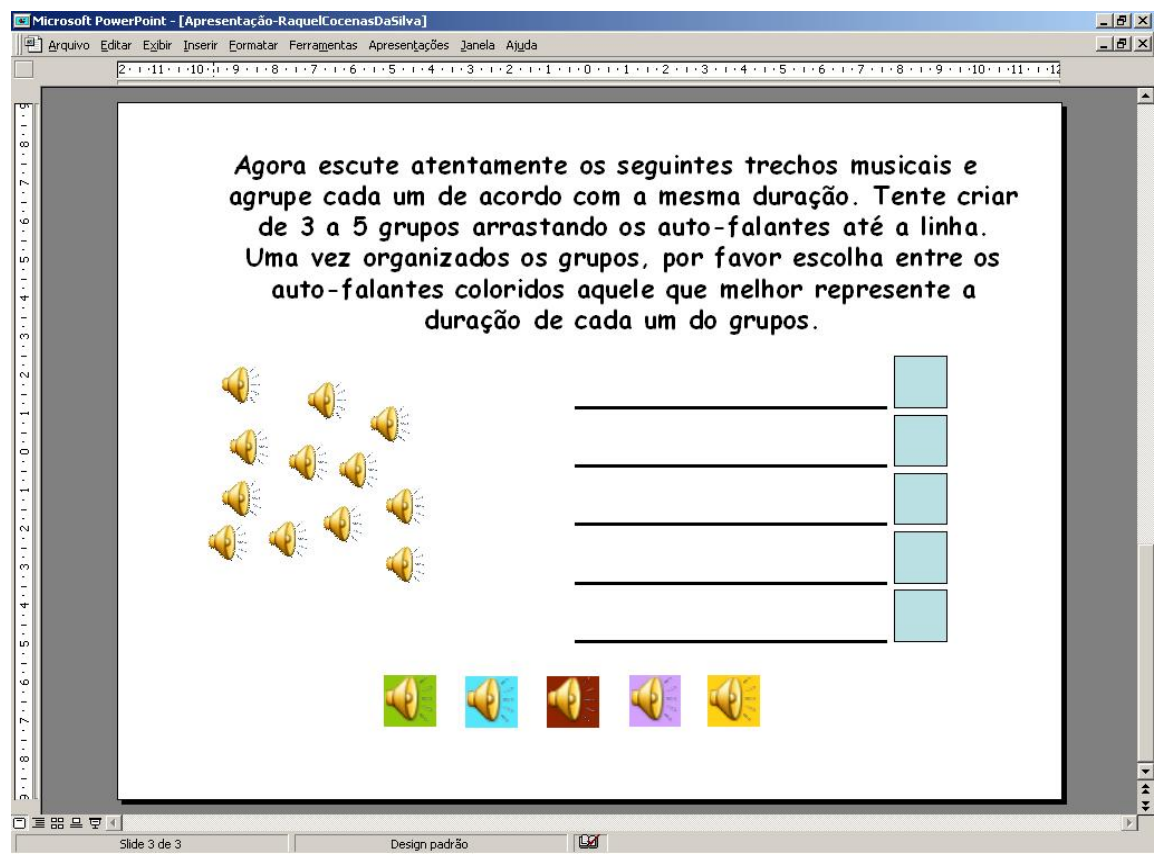

Os 12 alto-falantes localizados na parte esquerda da tela correspondiam aos trechos musicais utilizados no experimento. Eles estavam em ordem embaralhada. Por exemplo: o trecho musical ALE 02 não estava disposto abaixo do trecho musical ALE 02, e assim por diante. Cada um dos 12 alto-falantes deveria ser arrastado com o mouse para uma das cinco linhas horizontais, localizadas à direita, na tela. 
Os cinco alto-falantes coloridos, localizados na parte inferior da tela, correspondiam às mesmas durações sonoras apresentadas nas subtarefas anteriores e estavam organizados da menor para a maior duração. Porém, os participantes continuavam sem saber o tempo de duração deles. Não era informado aos participantes que os alto-falantes coloridos estavam em ordem crescente de duração.

A tarefa dos participantes consistiu em: (1) ouvir cada um dos 12 trechos musicais em ordem aleatória; (2) agrupá-los, conforme a duração de cada um deles, arrastando-os, com a ajuda do mouse, as cinco linhas horizontais (referentes às durações de 16, 18, 20, 22 e 24 segundos, respectivamente); (3) associar a duração de cada alto-falante colorido com a duração de cada grupo de trechos musicais formada. Para tal, cada alto-falante colorido deveria ser arrastado, com a ajuda do mouse, até a cada uma das caselas de cor azul clara, localizadas ao final das cinco linhas horizontais, no canto direito da tela. Cada casela deveria ser preenchida com apenas um alto-falante colorido.

Ao final da realização desta última subtarefa, aparecia uma mensagem de agradecimento, significando o final do experimento.

Portanto, com a realização deste conjunto de tarefas, os participantes associavam a duração de cada trecho musical com uma das durações-padrão empregadas no experimento $(16,18,20,22$ ou 24 segundos $)$.

Terminado o experimento, os participantes foram encaminhados em silêncio, para fora da sala experimental, para o preenchimento do questionário complementar.

Cada sessão experimental durava aproximadamente 35 minutos.

Análise dos dados: o teste de Kolmogorov-Smirnov (teste Z) foi aplicado para verificar a normalidade dos dados. $\mathrm{O}$ teste t-Student foi utilizado para comparar a média das associações 
temporais dos participantes músicos e não músicos com as durações reais de cada trecho musical, 20 segundos.

\subsubsection{RESULTADOS}

O teste de Kolmogorov-Smirnov (teste Z) foi aplicado para verificar a normalidade dos dados. Este teste apontou normalidade dos dados para todas as músicas apresentadas para o grupo Não Músicos. Para o grupo Músicos, a única música cujos dados rejeitaram normalidade foi a música $7(Z=1,436 ; p=0,032)$. Para todas as outras músicas, o teste $\mathrm{Z}$ confirmou a normalidade dos dados.

O teste t-Student forneceu o resultado mostrado na Tabela 4 que indica a média numérica e os desvios-padrão das durações temporais fornecidas pelos participantes músicos e não músicos através das tarefas de associação temporal. Foram consideradas diferenças estatísticas significativas os níveis de $\mathrm{p}<0,05$. As diferenças significativas estão assinaladas com um asterisco.

Tabela 4. Médias e desvios-padrão das associações temporais feitas por músicos e não músicos.

\begin{tabular}{|c|c|c|c|c|}
\hline Trechos musicais & \multicolumn{2}{|c|}{ Músicos } & \multicolumn{2}{c|}{ Não Músicos } \\
\hline & Médias (seg.) & Desvios-padrão & Médias (seg.) & Desvios-padrão \\
\hline ALE 01 & 19,5 & 2,14 & $18^{*}$ & 2,25 \\
\hline ALE 02 & 19,8 & 2,83 & 19,6 & 2,39 \\
\hline ALE 03 & 20,7 & 2,70 & 20,1 & 2,20 \\
\hline SER 01 & 20,2 & 2,33 & 21 & 2,29 \\
\hline SER 02 & $18,1^{*}$ & 2,29 & $17,6^{*}$ & 2,30 \\
\hline SER 03 & 19,4 & 2,44 & 19,1 & 2,94 \\
\hline TRI 01 & $18,1^{*}$ & 1,89 & 19,1 & 2,29 \\
\hline TRI 02 & $19 *$ & 1,89 & 19,6 & 2,39 \\
\hline TRI 03 & $18,7^{*}$ & 2,36 & $18,6 *$ & 1,96 \\
\hline MRV 01 & 20,2 & 2,42 & 21,3 & 2,70 \\
\hline MRV 02 & 19,6 & 2,64 & 20,1 & 2,47 \\
\hline MRV 03 & 19,1 & 2,38 & 18,8 * & 2,29 \\
\hline
\end{tabular}

* Indica subestimação temporal. 
Os dados presentes na Tabela 4 mostram que, para ambos os grupos de participantes, alguns trechos musicais foram subestimados em relação a suas durações reais (20 segundos). Para o grupo Músicos, foram subestimados os trechos musicais SER 02 (t (19) $=-3,707 ; \mathrm{p}=0,001)$, TRI $01(\mathrm{t}(19)=-4,498 ; \mathrm{p}=0,0001)$, TRI $02(\mathrm{t}(19)=-2,364 ; \mathrm{p}=$ 0,029) e o trecho musical TRI 03 ( $(19)=-2,459 ; \mathrm{p}=0,024)$. Para o grupo Não Músicos, foram subestimados os trechos musicais ALE $01(\mathrm{t}(19)=-3,979 ; \mathrm{p}=0,001)$, SER 02 ( $\mathrm{t}(19)$ $=-4,66 ; \mathrm{p}=0,0001)$, TRI $03(\mathrm{t}(19)=-3,199 ; \mathrm{p}=0,005), \operatorname{MRV} 03(\mathrm{t}(19)=-2,349 ; \mathrm{p}=$ $0,03)$.

Todos os outros trechos musicais não foram subestimados nem superestimados em relação às suas durações reais, para ambos os grupos.

Assim, os dados da Tabela 4 mostram que o trecho musical SER 02 foi subestimado para ambos os grupos. Porém, não foram constatadas diferenças estatísticas significativas para nenhum dos outros trechos musicais representativos da emoção Serenidade.

Para o grupo Músicos, houve subestimação temporal para todos os trechos musicais representativos da emoção Tristeza (TRI 01, TRI 02 e TRI 03).

Já para o grupo Não Músicos, houve subestimação temporal em pelo menos um trecho musical representativo de cada emoção analisada (Alegria, Serenidade, Tristeza e Medo/ Raiva). Portanto, os dados presentes na Tabela 4 nos permitem inferir que, para o grupo Não Músicos, a subestimação temporal não esteve associada a nenhuma emoção musical específica analisada neste estudo.

Analisando as diferenças de associação temporal dentro de cada grupo de trechos que representam uma mesma emoção, temos o seguinte: para o grupo Músicos, foram encontradas diferenças estatísticas significativas entre as associações temporais dos trechos 
musicais representativos da emoção Serenidade $[\mathrm{F}(2,57)=4,055 ; \mathrm{p}=0,023]$. Uma análise post-hoc apontou que o trecho musical SER 02 foi associado a uma duração mais curta que o trecho SER $01(\mathrm{p}=0,018)$. Ainda para o grupo Músicos, não foram encontradas diferenças estatísticas significativas entre os trechos musicais representativos de cada uma das outras emoções analisadas (Alegria, Tristeza e Medo/Raiva); já para o grupo Não Músicos, foram encontradas diferenças estatísticas significativas entre as associações temporais dos trechos musicais representativos das emoções Alegria $[\mathrm{F}(2,57)=4,625 ; \mathrm{p}=0,014]$, Serenidade $[\mathrm{F}(2,57)=9,078 ; \mathrm{p}=0,0001]$ e Medo/Raiva $[\mathrm{F}(2,57)=4,856 ; \mathrm{p}=0,011]$. Análises post-hoc apontaram que o trecho musical ALE 01 foi associado a uma duração mais curta que o trecho musical ALE $03(p=0,014)$, que o trecho musical SER 02 foi associado a uma duração mais curta que o trecho musical SER 03 e que o trecho musical MRV 03 foi associado a uma duração temporal mais curta que o trecho musical MRV 01. Ainda para o grupo Não Músicos, não foram encontradas diferenças estatísticas significativas entre os trechos musicais representativos da emoção Tristeza.

\subsubsection{DISCUSSÃO}

O presente experimento procurou verificar a influência de fatores emocionais desencadeados durante tarefas de escuta musical na percepção temporal de músicos e não músicos. Os dados obtidos apontam que, apesar do processamento emocional de músicos e não músicos serem semelhantes (BIGAND et al., 2005), o processamento temporal dos trechos musicais apresentados foi diferente entre os grupos. Com relação ao grupo Músicos, as subestimações temporais em relação à duração real de cada estímulo (20 segundos) foram encontradas para os três trechos musicais associados à emoção Tristeza e para apenas um trecho musical associado à emoção Serenidade. Com relação ao grupo Não Músicos, pelo 
menos um trecho associado a cada categoria emocional analisada (Alegria, Tristeza, Serenidade e Medo/ Raiva) foi subestimado em relação à sua duração real. Não houve nenhuma superestimação temporal sobre nenhum trecho musical para ambos os grupos. Portanto, os dados apresentados neste estudo sugerem que houve influência das emoções desencadeadas durante uma escuta musical na percepção temporal dos músicos participantes deste estudo. Considerando a emoção Tristeza como sendo uma emoção desencadeadora de índices de arousal e valência afetiva negativos (RUSSEL, 1980), pode-se inferir que houve um efeito aditivo destas duas dimensões na percepção temporal dos músicos. Assim, em condições de arousal e de valência afetiva negativos, o tempo subjetivo dos músicos foi subestimado.

Os resultados obtidos neste estudo convergem para alguns dos resultados obtidos por Angrilli et al. (1997). Apesar de estes autores não terem encontrado nenhum efeito do arousal e da valência afetiva (isolados) sobre a percepção do tempo, eles encontraram uma interação significante entre estas duas dimensões: em contextos envolvendo altos índices de arousal, a duração de figuras que sugeriam valências afetivas negativas foi superestimada em relação à duração de figuras que sugeriam valência afetiva neutra ou positiva em sujeitos não treinados em música; em contextos envolvendo baixos índices de arousal, figuras que sugeriam valência afetiva negativa foram subestimadas e figuras que sugeriam valência afetiva positiva foram superestimadas. No entanto, diferentemente deste estudo, estes dados de Angrilli et al. (1997) foram obtidos por meio de experimentos envolvendo curtas durações (da ordem de dois segundos) e em sujeitos não treinados em música. Os autores não encontraram nenhuma influência das emoções sobre a percepção temporal para longas durações (acima de dois segundos). Apesar disso, os dados obtidos neste experimento convergiram para os dados de Angrilli et al. (1997) referentes à subestimação temporal para valências negativas em contextos que envolvem arousal negativo: neste estudo, 
a percepção temporal dos músicos também foi subestimada em uma situação de baixos índices de arousal. Houve, portanto, um indício de que, independente do tipo de sujeito (músico ou não- músico), do tamanho ou da qualidade (sonora ou visual) do estímulo a ser mensurado temporalmente, o processamento temporal de eventos que sugiram condições de arousal e valência afetiva negativos é parecido.

A nova estética experimental proposta por Berlyne (1974) sugere a familiaridade como sendo um fator importante a ser considerado em estudos envolvendo apreciações artísticas. Segundo este autor, a relação da familiaridade do tipo de sujeito envolvido com o tipo de evento sensorial utilizado é uma variável que deve ser minuciosamente investigada. E nossos dados confirmam a importância da relação da familiaridade do tipo de sujeito com o tipo de evento envolvido em tarefas de associação temporal: se Angrilli et al. (1997) encontraram subestimações temporais de eventos pictóricos que sugeriam arousal e valência afetiva negativos e os dados aqui obtidos mostram subestimações temporais de eventos musicais sobre as mesmas condições, é possível inferir uma hipótese de que sujeitos não músicos possam se envolver mais emocionalmente com estímulos visuais do que com estímulos musicais. Segundo Bigand et al. (2005), sujeitos treinados em música processam as informações musicais de forma mais "refinada" do que os não músicos. Este dado converge para outros dados encontrados na literatura, em relação a uma maior homogeneidade de respostas emocionais a uma mesma música dos músicos em relação aos não músicos (WATERMAN, 1996; KOELSCH et al., 2000; SCHERER; ZENTNER, 2001; GALVÃO, 2006). Por terem processado a emoção Tristeza de forma tão "refinada" (e por terem se envolvido tanto com ela durante a apresentação dos estímulos), é possível que os participantes músicos do presente estudo tenham perdido a noção do tempo durante a escuta destes trechos musicais, desencadeadores de Tristeza. Esta hipótese pode ser confirmada por meio do questionário aplicado após a realização do Experimento I do presente 
estudo, que continha uma questão referente à familiaridade dos participantes com os trechos musicais envolvidos. A partir da análise destes questionários, foi possível verificar que a maioria dos músicos nomeou os trechos musicais que desencadearam Tristeza. $\mathrm{O}$ mesmo não ocorreu para os não músicos. Portanto, estímulos musicais podem "facilitar" a mensuração do papel das emoções na percepção temporal dos músicos, pelo fato de estes lidarem com respostas musicais de forma "mais familiar" do que os não músicos.

A diferença entre o processamento temporal de eventos pictóricos e sonoros foi sistematicamente estudada por Droit-Volet, Tourret e Wearden (2004). Estes autores realizaram um estudo envolvendo crianças de 5 a 8 anos e também adultos, por meio de procedimentos de bissecção temporal em estímulos visuais e sonoros curtos (de 200 a 800 milisegundos de duração). Na primeira seção experimental, participantes comparavam as durações dos estímulos com as durações padrões (uma curta e outra longa) sobre uma mesma modalidade (visual ou sonora), denominada sessão intramodalidade e, na segunda sessão, realizavam a mesma tarefa sobre modalidades diferentes (sessão intermodalidades). Os resultados indicaram que, independente da faixa etária considerada, houve superestimação de estímulos sonoros em relação aos estímulos visuais, com maiores diferenças estatísticas sobre os dados dos sujeitos adultos em relação às crianças de 8 e 5 anos de idade, respectivamente. Portanto, estudos sistemáticos envolvendo o processamento temporal de músicos e não músicos precisam ser realizados, no intuito de clarificar ainda mais a influência das emoções na percepção temporal de ambos os grupos. Estes estudos podem ser realizados a partir da mensuração de variáveis como tipo de evento (visual ou sonoro), durações envolvidas (curtas ou longas), tipo de metodologia utilizada (bissecção, comparação, reprodução temporais, etc.).

Com relação aos modelos de percepção temporal encontrados na literatura, dois deles parecem dar conta de explicar os resultados obtidos no presente estudo. 
O modelo atencional, proposto por Hicks, Miller e Kinsbourne (1976), sugere um processamento cognitivo de acordo com a distribuição de reservas de memória solicitada pelo grau de atenção exigido no cumprimento da tarefa de associação temporal. Assim, quanto maior é a demanda atencional do sujeito em relação à tarefa temporal, maior é o esforço mental exigido para que as informações temporais sejam arquivadas na memória e, por esta razão, maior será a estimação temporal. Uma hipótese para explicar os dados obtidos neste estudo é a de que as subestimações temporais referentes aos trechos musicais desencadeadores de Tristeza nos músicos tenham ocorrido devido ao forte envolvimento emocional destes sujeitos com estes trechos musicais, a ponto de tê-los distraído em relação à tarefa temporal. Assim, para os músicos deste estudo, o processamento temporal pode ter sido desenvolvido da seguinte maneira: num primeiro momento da escuta, pode ter havido o envolvimento emocional do sujeito e a conseqüente distração em relação à tarefa temporal; logo em seguida, num segundo momento, ainda durante a escuta, o sujeito pode ter voltado a sua atenção, para a tarefa temporal; no entanto, no momento da associação do trecho musical às durações temporais, o sujeito pode não ter levado em conta estes segundos iniciais em que estava mais envolvido com a emoção desencadeada pelo trecho musical do que com a realização da tarefa temporal propriamente dita. A conseqüência disso foi uma menor demanda atencional do sujeito em relação à tarefa temporal e, portanto, houve um menor esforço mental exigido para que as informações temporais fossem arquivadas na memória e, por esta razão, podem ter ocorrido as subestimações temporais. Em outras palavras, as atmosferas emocionais de tristeza podem ter diminuído a atenção dos músicos em relação às tarefas de associação temporal.

O modelo proposto por Gibbon, Church e Meck (1984) baseia-se na existência de um relógio interno que avalia o tempo objetivo (externo) de maneira subjetiva. De acordo com a sua teoria do "timing escalar", este mecanismo de relógio interno é composto por um 
marcapasso que emite pulsos e um interruptor que controla a atenção temporal. Este emissor de pulsos é acionado e paralisado, respectivamente, do início ao fim do estímulo, permitindo, assim um acúmulo de pulsos durante a apresentação do evento a ser estimado. A estimação temporal, então, está baseada em um número de pulsos acumulados: quanto maior o número de pulsos, maior o tempo a ser julgado. Outra hipótese para explicar os dados obtidos neste estudo também se refere ao maior envolvimento emocional dos sujeitos músicos com a emoção Tristeza do que com a tarefa temporal. Assim, para os músicos deste estudo, segundo este modelo, o processamento temporal pode ter sido desenvolvido da seguinte maneira: num primeiro momento da escuta, o emissor de pulsos pode ter sido disparado pelo sujeito; num segundo momento, pode ter ocorrido o envolvimento emocional do sujeito ao trecho musical; este envolvimento pode ter sido muito forte, sendo capaz de fazer com que o sujeito perdesse a noção do número de pulsos acumulados até então; num terceiro momento, quando o sujeito voltou a sua atenção para a tarefa temporal, o emissor de pulsos pode ter sido acionado novamente até o final do evento; a associação temporal do sujeito, portanto, pode ter sido baseada na soma dos pulsos iniciais com os pulsos finais do evento, subtraindo-se os pulsos perdidos durante o envolvimento emocional ao trecho musical. Esta última perda, portanto, pode ter sido o elemento causador da subestimação temporal para este grupo de sujeitos.

A conclusão deste experimento é a de que houve influência de uma emoção específica (no caso, a Tristeza) na percepção temporal de músicos. Além disso, este estudo reforça a idéia de Angrilli (1997), a respeito da ocorrência de subestimações temporais em relação a eventos desencadeadores de arousal e valência afetiva negativos. Porém, diferentemente dos dados obtidos por este autor, nenhuma superestimação temporal foi encontrada. Este estudo ainda alertou sobre como as emoções podem interferir em tarefas de associação temporal: os dados aqui obtidos mostram que esta interferência pode estar 
relacionada com o tipo de sujeito envolvido (no caso, músicos) e com o tipo de evento mensurado (no caso, a música).

No entanto, ainda não ficou esclarecido o que, de fato, interferiu nas associações temporais referentes às outras categorias emocionais empregadas neste estudo, uma vez que, além de subestimações temporais referentes a trechos musicais associados à Tristeza, para o grupo Músicos, outra subestimação temporal foi encontrada para mais um trecho associado à emoção Serenidade para este grupo. Além disso, subestimações também foram encontradas para pelo menos um trecho musical referente a cada emoção analisada, considerando os não músicos. A partir destes dados, por que, então, não houve influência de mais alguma emoção específica na percepção temporal dos grupos de sujeitos envolvidos? Uma hipótese a ser considerada poderia estar centrada na idéia de que os trechos musicais associados às outras categorias emocionais (Alegria, Serenidade e Medo/Raiva) não foram capazes de envolver os sujeitos a atividades emocionais intensas a ponto de alterar a percepção subjetiva do tempo. Uma segunda hipótese poderia estar centrada na existência de alguma característica estrutural da música (como modo, andamento, contorno melódico, timbre, etc.) que poderia atuar de forma decisiva na percepção subjetiva de tempo, independentemente da emoção desencadeada durante a escuta musical. Ou ainda, uma terceira hipótese a ser considerada poderia estar centrada na idéia de que o tempo subjetivo (de músicos e não músicos) poderia ser alterado pela interação entre estes dois fatores (propriedades emocionais percebidas pelos ouvintes e propriedades estruturais da própria música).

No intuito de tentar responder às questões anteriormente propostas, por meio de uma análise aprofundada sobre as três hipóteses mencionadas, o presente estudo procurou verificar respostas emocionais e associações temporais sobre alguns trechos musicais com manipulação de certos parâmetros estruturais da música, como o modo e o andamento. Para este fim, os experimentos III e IV foram realizados. 
3.3. EXPERIMENTO III 


\subsubsection{INTRODUÇÃO}

Vários estudos sobre respostas emocionais à música foram realizados por meio da manipulação de diversos parâmetros musicais: intervalos musicais (TRAINOR; HEINMILLER, 1998), contornos melódicos (JUSLIN, 2005), funções harmônicas tonais (SLOBODA, 1991; PARNCUTT, 1999; PERETZ, 2002; STEINBEIS; KOELSCH; SLOBODA, 2006), textura (WEBSTER; WEIR, 2005), modo e andamento (GREGORY; WORRAL; SARGE, 1996; DALLA BELLA et al., 2001a, 2001b) e ritmo (SCHERER; ZENTNER, 2001). Mas quais seriam os parâmetros musicais que mais influenciariam respostas emocionais à música? A literatura aponta o modo musical e o andamento como os parâmetros que respondem de forma mais satisfatória a esta questão.

Os efeitos do modo musical e do andamento foram estudados de forma mais sistemática desde o início do século passado (HEVNER, 1935) e a maior parte deles vem utilizando manipulações em dois modos musicais - maior ou menor - e, na maioria dos casos, dois andamentos - lento ou rápido - (SHERER; OSHINSKY, 1997; DALLA BELLA et al., 2001a), o que pode resultar em uma simplificação da compreensão das respostas emocionais à música. Por exemplo: um trecho musical pode ser percebido como "alegre" ou "triste", dependendo da combinação entre estes dois parâmetros: um trecho musical em modo maior e andamento rápido é percebido como sendo "alegre" e em um modo menor e um andamento lento é percebido como sendo "triste" (condição convergente); no entanto, em alguns casos, relatos foram obtidos a respeito de respostas emocionais ambíguas, em que um mesmo trecho musical foi associado tanto à alegria, como à tristeza. Esta ambigüidade foi encontrada quando foram apresentados trechos musicais em modo maior e andamento lento ou trechos musicais em modo menor e andamento rápido (condição divergente), (JUSLIN; LAUKKA, 2003; DALLA BELLA et al., 2001b; JUSLIN; SLOBODA, 2001; LARSEN; MCGRAW; CACIOPPO, 2001; KRUMHANSL, 1997). 
Alguns pesquisadores têm investigado o efeito da mudança progressiva do andamento musical em respostas emocionais (RIGG, 1940; WEBSTER; WEIR, 2005). Neste último estudo, três andamentos (lento, moderado, rápido) foram utilizados. Conforme os trechos musicais eram apresentados aos ouvintes, aumentando o andamento, do lento ao moderado e do moderado ao rápido, as associações emocionais à Tristeza foram diminuindo, dando lugar às associações emocionais à Alegria. Estes estudos, no entanto, contrastaram dois modos musicais (um maior e outro menor) e incidiram sobre a distinção entre "alegre" e “triste”, apenas. Como conseqüência, fica bastante difícil imaginar como o efeito progressivo de outros modos musicais poderia contribuir para um esclarecimento mais aprofundado acerca do processamento das emoções musicais dos ouvintes.

Modos maiores e menores são apenas dois exemplos dos sete modos gregos, utilizados na música ocidental. Este modos (Jônio, Dórico, Frígio, Lídio, Mixolídio, Eólio e Lócrio) sempre estiveram associados a diferentes contextos sociais no decorrer da história, no intuito de sugerir humores específicos nos ouvintes, alguns deles, inclusive, sendo mais apropriados para alguns contextos do que outros (LOVELOCK, 2001). Os sete modos têm, portanto, uma longa história e ainda estão vivos, em vários contextos musicais, sugerindo que suas organizações específicas toquem em um sólido processo de respostas emocionais que regem a música (RAMOS; BUENO; BIGAND, no prelo).

De um ponto de vista cognitivo, a característica fundamental para o uso dos modos gregos é a de que eles são construídos sobre um conjunto fixo de sete notas musicais (dó, ré, mi, fá, sol, lá e si) e, conseqüentemente, sobre distribuições intervalares específicas, de forma que cada modo possui uma nota musical atuando como referência. A especificidade de cada modo está fortemente associada aos intervalos musicais formados entre a nota referência e as outras notas musicais que o modo possui. De acordo com Wisnik (2004), essas mudanças relacionadas às distâncias intervalares entre as notas de referência e as outras seis notas de cada 
modo permitem organizar uma hierarquia que sugere uma explicação lógica e linear, que leva em conta o grau de "obscuridade" ou "claridade" que cada modo pode desencadear durante uma escuta musical (vide item 1.4.4. da Introdução do presente estudo). A hierarquia modal também sugere que a valência afetiva musical se tornaria negativa com o aumento da "obscuridade" do modo. Esta "obscuridade" aumentaria conforme os intervalos formados entre as notas do modo e a sua nota de referência se tornassem menores ou diminuídos. Abordar o impacto psicológico destes modos ajudaria na compreensão do efeito de estruturas intervalares musicais sobre as respostas emocionais dos ouvintes. Se fosse comprovado que a alteração da nota de referência de um determinado conjunto de notas fosse o suficiente para desencadear vários tipos de emoção nos ouvintes, este estudo contribuiria para fornecer alguma prova de que respostas emocionais à música podem estar profundamente enraizadas na cognição (e não na história pessoal de cada um). Como tal, este experimento poderá contribuir para realçar processos cognitivos envolvidos nas emoções musicais (JUSLIN; VÄSTFJÄLL, no prelo).

A manipulação de vários modos e vários andamentos também contribui para realçar a estrutura de respostas emocionais à música. Se respostas emocionais são organizadas ao longo de quatro principais categorias (Alegria, Tristeza, Serenidade ou Medo/Raiva), as mudanças no modo e no andamento iriam resultar em mudanças bruscas de percepção de emoção de uma para outra categoria. Em contrapartida, uma abordagem multidimensional da emoção, a partir da manipulação de modos e andamentos, iria resultar em mudanças emocionais progressivas, percebidas ao longo das dimensões de arousal e valência afetiva. Por exemplo: um trecho musical percebido como "triste" poderia, com o aumento no seu andamento, ser percebido como "alegre". Este mesmo trecho poderia ser associado à Serenidade ou Medo/Raiva alterando-se o seu modo, progressivamente, conforme a hierarquia modal sugerida por Wisnik (2004). 
Assim como nos experimentos I e II do presente trabalho, a expertise musical será testada, uma vez que os dados obtidos nos dois experimentos realizados anteriormente mostraram dados contrastantes em relação aos processamentos emocionais e temporais de músicos e não músicos.

Portanto, o objetivo deste experimento é verificar a influência do modo e do andamento musical no desencadeamento de emoções específicas em ambos os grupos de ouvintes. Para tal, serão mensuradas respostas emocionais a trechos musicais construídos em sete diferentes modos (Jônio, Dórico, Frígio, Lídio, Mixolídio, Eólio e Lócrio) e três diferentes andamentos musicais (adágio, moderato e presto).

\subsubsection{MÉTODO}

Participantes: a amostra de participantes foi divida em dois grupos: 30 músicos, estudantes de um curso de graduação em Música, que tinham pelo menos seis anos de experiência de estudo sistematizado de algum instrumento musical oferecido pelo curso (piano, violão, violino, viola, violoncelo, contrabaixo, flauta transversal, clarineta, trombone ou saxofone) e 30 não músicos (participantes que não tinham nenhuma experiência em estudo de música). Todos os participantes tinham entre 18 e 25 anos de idade (média $=21,9$ anos). Nenhum participante deste experimento teve participação nos Experimentos I e II.

Equipamento e material: neste experimento, foram utilizados os mesmos equipamentos e materiais utilizados para mensurar as categorias emocionais Alegria, Tristeza, Serenidade, Medo/Raiva, descritos no Experimento I, exceto os trechos musicais. 
As músicas escolhidas para este estudo foram três trechos musicais, com 36 segundos de duração, compostos pelo próprio experimentador, originalmente configurados no modo Jônio. Estes trechos musicais foram transpostos para os outros seis modos musicais analisados: Dórico, Frígio, Lídio, Mixolídio, Eólio e Lócrio. Cada trecho musical também foi transposto para três andamentos diferentes (Adágio, Moderato e Presto), configurando um total de 63 trechos musicais ( 3 músicas x 7 modos x 3 andamentos). Os trechos construídos no andamento Adágio tinham 72 batidas por minuto. Os trechos construídos no andamento Moderato tinham 108 batidas por minuto. Os trechos construídos no andamento Presto tinham 184 batidas por minuto. Todos os trechos musicais tinham a mesma estrutura melódica e rítmica. A intensidade na faixa de freqüência média de cada estímulo será de 50 dB (confortável para os participantes). Os trechos musicais foram escritos no programa Encore for musicians, 4.0 (Passport Designs), transformados em arquivos do tipo wave, sintetizados em um estúdio de gravação, para melhor equalização do som e depois armazenados nos discos rígidos dos notebooks utilizados na coleta. $\mathrm{O}$ timbre escolhido para os estímulos foi o piano. Todos os trechos musicais foram construídos com melodias harmonizadas, com o objetivo de caracterizar tanto a melodia quanto a harmonia típica de cada modo musical. A estrutura harmônica de cada trecho foi construída a partir das cadências características de cada modo musical (ver Composição dos trechos musicais, a seguir).

Composição dos trechos musicais modais: todos os trechos musicais foram compostos pelo próprio experimentador, levando-se em conta os critérios relacionados à Harmonia Modal estabelecidos por Persichetti (1996). Assim, o fato de o ouvinte apreciar trechos musicais inéditos permite o controle da variável "familiaridade", que pode interferir nas associações emocionais e temporais dos participantes (BERLYNE, 1974). 
Cada uma das notas musicais que pertencem a cada modo pode receber mais duas notas adicionais e simultâneas (construídas sobre intervalos de terças), caracterizando assim, uma tríade. As tríades construídas sobre cada nota de cada modo musical podem ser de três tipos: maiores, menores ou diminutas. Tal classificação depende do intervalo formado entre a primeira e a segunda nota e entre a segunda e a terceira nota da tríade. Se uma tríade tiver notas que formam os intervalos de terça maior e terça menor, respectivamente, esta tríade é classificada como maior. Se uma tríade tiver notas que formam os intervalos de terça menor e terça maior, respectivamente, esta tríade é classificada como menor. Tríades contendo dois intervalos de terça menor são classificadas como diminutas. Conforme esta organização, cada modo possui, no decorrer de sua escala, três tríades maiores, três tríades menores e uma tríade diminuta (ver em Caracterização dos modos musicais, a seguir). A localização de cada tríade varia conforme o modo. Por exemplo, as tríades maiores encontradas no modo Jônio localizam-se nos acordes construídos sobre os graus I, IV e V; no entanto, as tríades maiores encontradas no modo Eólio localizam-se nos acordes construídos sobre os graus III, VI e VII e assim por diante.

Para se estabelecer uma classificação sonora típica de cada modo musical, o procedimento a ser tomado, segundo as regras de Harmonia Modal estabelecidas por Persichetti (1996), foi o seguinte:

Primeiro passo: $\mathrm{O}$ modo Jônio é praticamente o modo maior utilizado na música ocidental e o modo Eólio (com alguma alteração) é praticamente o modo menor (LOVELOCK, 2001). Por este motivo, o modo Jônio foi usado como controle para comparação com os outros modos maiores (Lídio e Mixolídio). O modo Eólio, por sua vez, foi o "modo controle" para comparação com os outros modos menores (Dórico, Frígio, Eólio e Lócrio). O primeiro passo, portanto, foi considerar estes dois modos como "modos-padrão" para a construção dos trechos musicais. 
Segundo passo: encontrar, em cada um dos outros modos, uma ou duas notas musicais "estranhas" às notas musicais estabelecidas pelos modos-padrão. Estas notas "estranhas" serão chamadas de "notas características de cada modo musical", ou seja, são as notas que são diferentes entre cada modo e o seu modo-padrão (maior ou menor, conforme o caso).

Terceiro passo: considerar apenas as tríades maiores e menores construídas sobre estas notas “estranhas", desconsiderando, assim, a tríade diminuta.

Quarto passo: estabelecer as cadências modais características de cada modo musical, considerando as tríades do primeiro grau de cada modo (que podem ser maiores ou menores, conforme o caso) e as tríades construídas sobre estas notas características de cada modo, menos a tríade diminuta.

\section{Caracterização dos modos musicais}

\section{Modos maiores}

\section{Modo Jônio}

A Figura 5 mostra as tríades encontradas sobre a escala do modo Jônio.

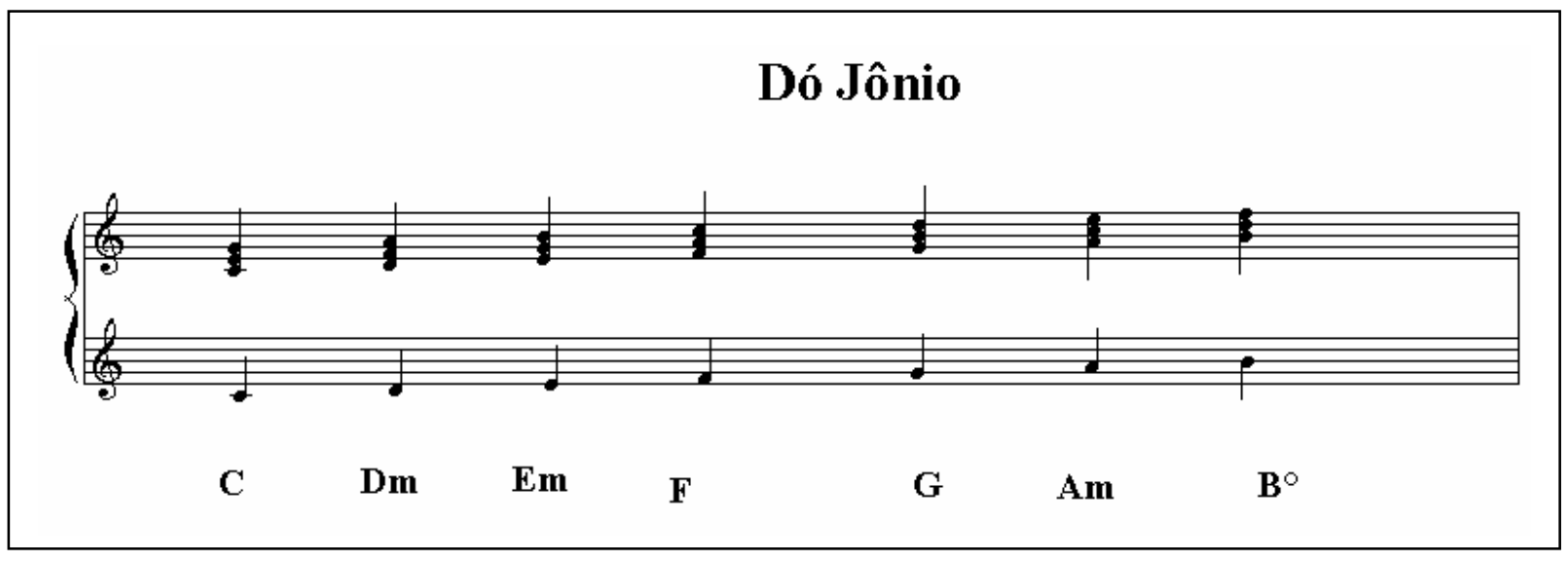

Figura 5. Tríades encontradas sobre a escala do modo Jônio 
Pelo fato de o modo Jônio ser considerado o modo maior padrão no presente estudo, as suas cadências principais foram obtidas a partir das tríades formadas sobre os graus I, IV e V. Estes graus (funções harmônicas) passaram a ser chamados, pela teoria musical relacionada à música ocidental de "funções tonais principais" (HINDEMITH, 1944). A partir das funções tonais principais, pode-se estabelecer uma relação de conclusão ou de continuidade sonora, conforme a combinação de acordes da seqüência harmônica empregada. A função I denomina-se "tônica" (T) e dá a sensação de conclusão sonora, ou seja, a seqüência harmônica parece ter chegado a seu final. A função V denomina-se "dominante" e dá uma sensação de que "está faltando algum acorde para concluir a seqüência harmônica". A função IV denomina-se "subdominante" (S) e dá uma sensação de "continuidade", ou seja, a idéia da existência de um espaço livre para que a seqüência harmônica seja desenvolvida (WISNIK, 2004). Uma organização destas funções harmônicas por meio de seqüências de acordes musicais dá origem a cadências (progressões harmônicas). As cadências principais do modo Jônio (maior padrão) foram denominadas: Autêntica, Plagal e Perfeita pela teoria musical ocidental (SCHÖENBERG, 2002).

A Figura 6 mostra as cadências encontradas para o modo Jônio, conforme os critérios estabelecidos por Persichetti (1996):

$$
\begin{gathered}
\text { I - IV - I } \rightarrow \text { Cadência Plagal maior } \\
\text { I - V - I } \rightarrow \text { Cadência Autêntica maior } \\
\text { I }- \text { IV }- \text { V - I } \rightarrow \text { Cadência Perfeita maior }
\end{gathered}
$$

Figura 6. Cadências musicais encontradas para o modo Jônio. 
Os acordes encontrados nas cadências ilustradas na Figura 6 foram: "dó maior" (primeiro grau da escala), "fá maior" (quarto grau da escala) e "sol maior" (quinto grau da escala), cujas cifras são “C", "F" e "G", respectivamente. Os trechos musicais construídos sobre o modo Jônio empregados no presente estudo possuíam, portanto, uma melodia construída sobre as notas “dó, ré, mi, fá, sol, lá e si” (escala do modo Jônio), com uma harmonia construída sobre as cadências musicais descritas na Figura 6.

\section{Modo Lídio}

A Figura 7 mostra as tríades encontradas sobre a escala do modo Lídio.

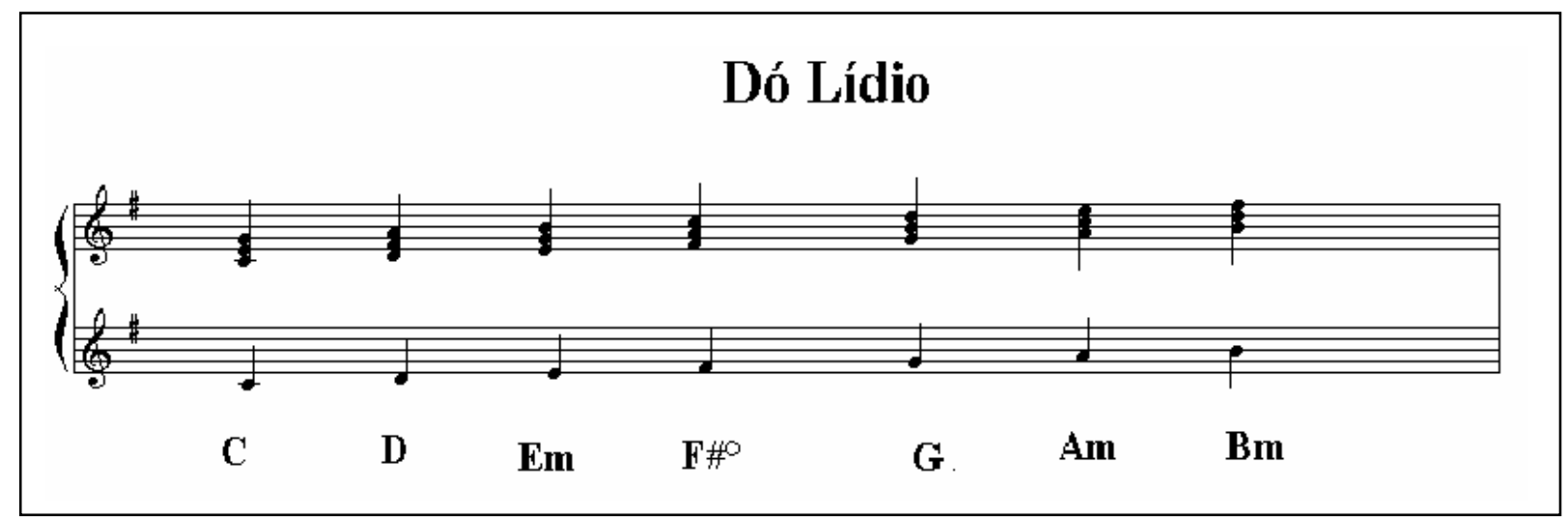

Figura 7. Tríades encontradas sobre a escala do modo Lídio.

De acordo com os critérios estabelecidos por Persichetti (1996), para se encontrarem as cadências características do modo Lídio, considera-se a tríade construída sobre o primeiro grau do modo e as tríades construídas sobre a nota fá sustenido, que é a nota que torna o modo Lídio diferente do modo Jônio ${ }^{3}$. O intervalo formado entre a nota do primeiro grau do modo (dó) e a nota fá sustenido é uma quarta aumentada. Portanto, a nota

\footnotetext{
${ }^{3}$ Para facilitar a comparação entre as cadências principais típicas de cada modo musical empregado no presente estudo, todas as tríades encontradas sobre cada escala modal foram construídas a partir da nota "dó".
} 
característica do modo Lídio é a quarta aumentada. A Figura 8 mostra as cadências musicais encontradas no modo Lídio, após o descarte de sua tríade diminuta:

$$
\begin{gathered}
\text { I - II - I } \rightarrow \text { Cadência primária do modo Lídio } \\
\text { I - VIIm - I } \rightarrow \text { Cadência secundária do modo Lídio }
\end{gathered}
$$

Figura 8. Cadências musicais encontradas para o modo Lídio.

Os acordes encontrados nas cadências ilustradas na Figura 8 foram: "dó maior" (primeiro grau da escala), "ré maior" (segundo grau da escala) e "si menor" (sétimo grau da escala), cujas cifras são "C", " $\mathrm{D}$ " e "Bm", respectivamente. Os trechos musicais construídos sobre o modo Lídio, empregados no presente estudo, possuíam, portanto, uma melodia construída sobre as notas “dó, ré, mi, fá sustenido, sol, lá e si” (escala do modo Lídio), com uma harmonia construída sobre as cadências musicais descritas na Figura 8.

\section{Modo Mixolídio}

A Figura 9 mostra as tríades encontradas sobre a escala do modo Mixolídio.

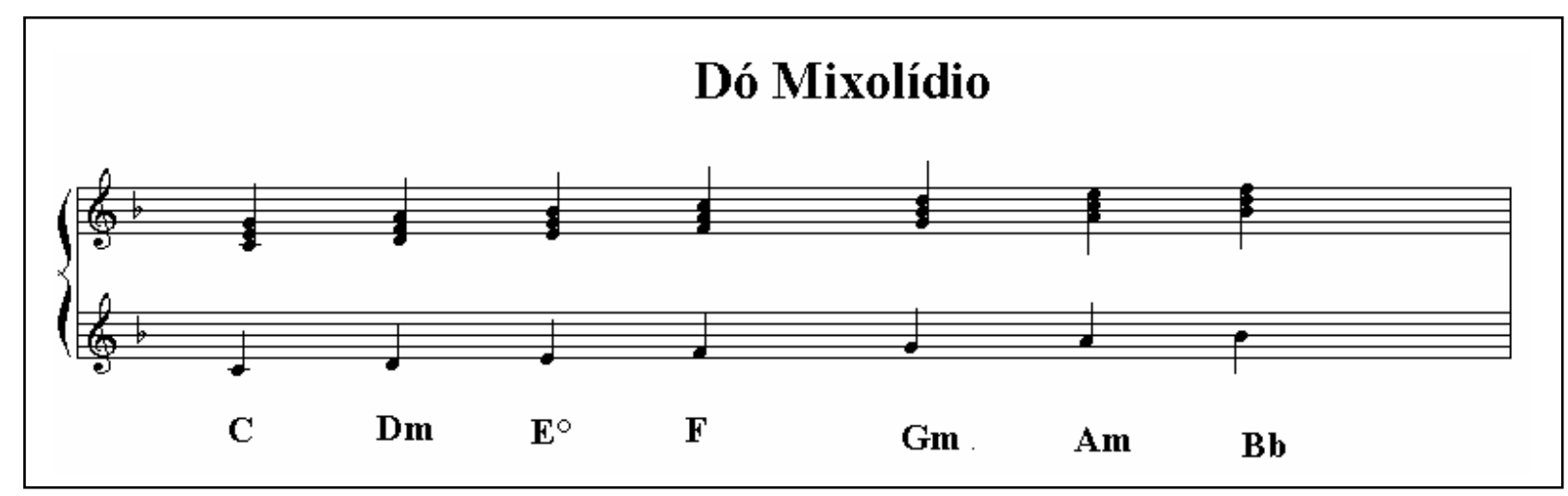

Figura 9. Tríades encontradas sobre a escala do modo Mixolídio. 
De acordo com os critérios estabelecidos por Persichetti (1996), para se encontrarem as cadências características do modo Mixolídio, considera-se a tríade construída sobre o primeiro grau do modo e as tríades construídas sobre a nota si bemol, que é a nota que torna o modo Mixolídio diferente do modo Jônio. $\mathrm{O}$ intervalo formado entre a nota do primeiro grau do modo (dó) e a nota si bemol é uma sétima menor. Portanto, a nota característica do modo Mixolídio é a sétima menor. A Figura 10 mostra as cadências musicais encontradas no modo Mixolídio, após o descarte de sua tríade diminuta:

$$
\begin{gathered}
\text { I - Vm - I } \rightarrow \text { Cadência primária do modo Mixolídio } \\
\text { I - bVII - I } \rightarrow \text { Cadência secundária do modo Mixolídio }
\end{gathered}
$$

Figura 10. Cadências musicais encontradas para o modo Mixolídio.

Os acordes encontrados nas cadências ilustradas na Figura 10 foram: "dó maior" (primeiro grau da escala), "sol menor" (quinto grau da escala) e "si bemol maior" (sétimo grau da escala), cujas cifras são "C", "Gm" e "Bb”, respectivamente. Os trechos musicais construídos sobre o modo Mixolídio, empregados no presente estudo, possuíam, portanto, uma melodia construída sobre as notas “dó, ré, mi, fá, sol, lá e si bemol” (escala do modo Mixolídio), com uma harmonia construída sobre as cadências musicais descritas na Figura 10.

\section{Modos menores}

\section{Modo Eólio}

A Figura 11 mostra as tríades encontradas sobre a escala do modo Eólio. 


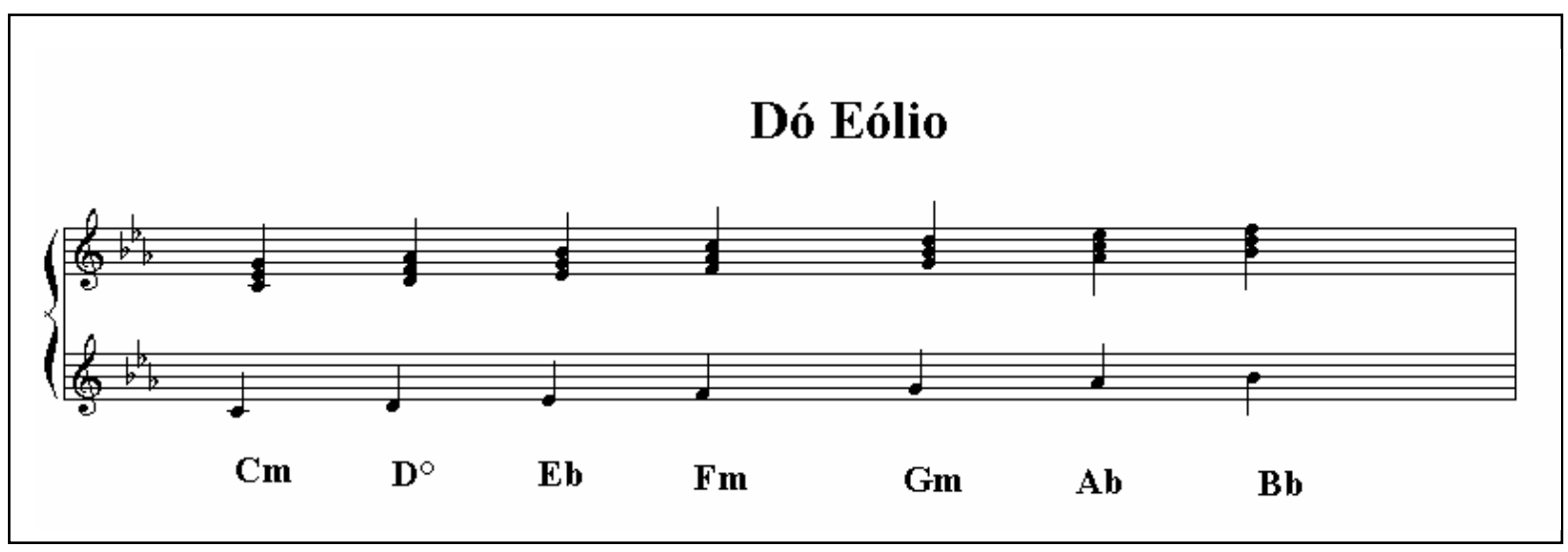

Figura 11. Tríades encontradas sobre a escala do modo Eólio.

Os critérios utilizados para a construção dos trechos musicais construídos no modo Eólio foram os mesmos utilizados para a construção dos trechos musicais construídos no modo Jônio, respeitando, no entanto, as notas da escala musical do modo Eólio (dó, ré, mi bemol, fá, sol, lá bemol e si bemol). Pelo fato de o modo Eólio ser considerado o modo menor padrão, as suas cadências principais foram obtidas a partir de cadências construídas pelas tríades formadas sobre os graus I, IVm e Vm (suas funções tonais principais).

A Figura 12 mostra as cadências encontradas para o modo Eólio, conforme os critérios estabelecidos por Persichetti (1996):

$$
\begin{gathered}
\mathrm{Im}-\mathrm{IVm}-\mathrm{Im} \rightarrow \text { Cadência Plagal menor } \\
\mathrm{Im}-\mathrm{Vm}-\mathrm{Im} \rightarrow \text { Cadência Autêntica menor } \\
\mathrm{Im}-\mathrm{IVm}-\mathrm{Vm}-\mathrm{Im} \rightarrow \text { Cadência Perfeita menor }
\end{gathered}
$$

Figura 12. Cadências musicais encontradas para o modo Eólio.

Os acordes encontrados nas cadências ilustradas na Figura 12 foram: "dó menor" (primeiro grau da escala), "fá menor" (quarto grau da escala) e "sol menor" (quinto grau da escala), cujas cifras são "Cm", "Fm” e "Gm”, respectivamente. Os trechos musicais construídos sobre o modo Eólio, empregados no presente estudo, possuíam, portanto, uma 
melodia construída sobre as notas da escala do modo Eólio, com uma harmonia construída sobre as cadências musicais descritas na Figura 12.

\section{Modo Dórico}

A Figura 13 mostra as tríades encontradas sobre a escala do modo Dórico.

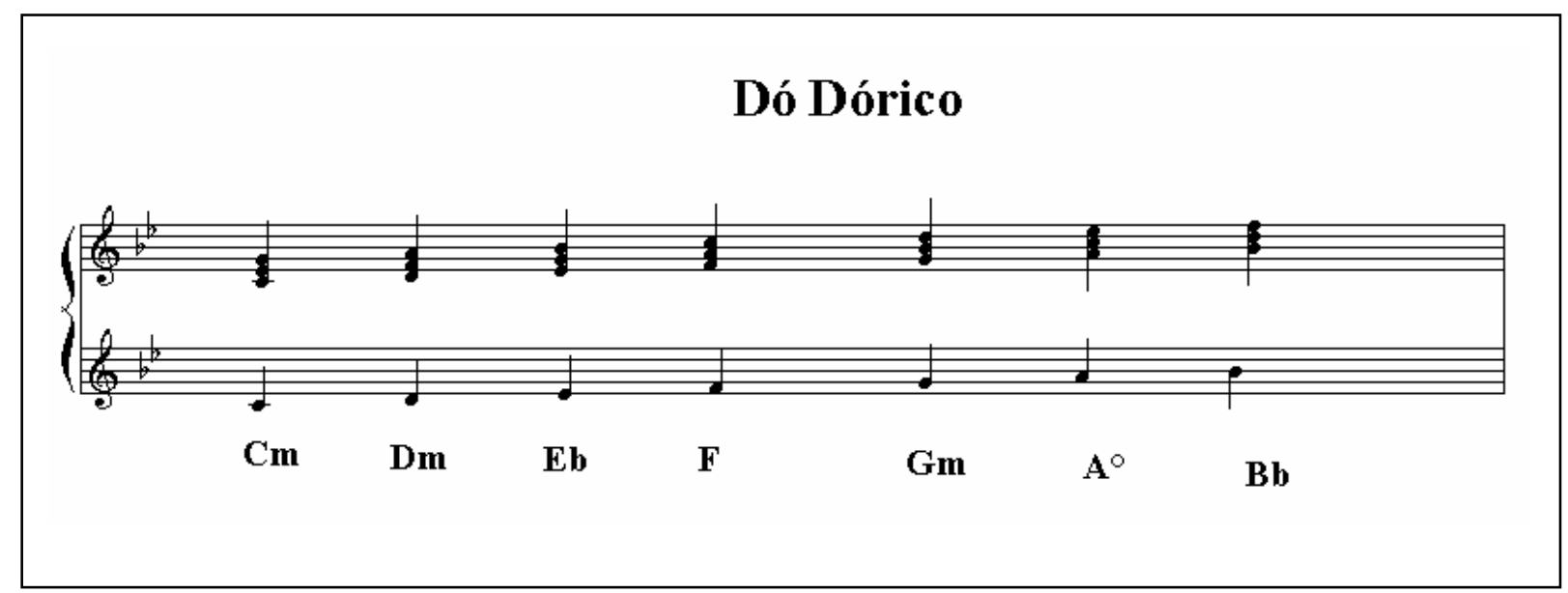

Figura 13. Tríades encontradas sobre a escala do modo Dórico.

De acordo com os critérios estabelecidos por Persichetti (1996), para se encontrarem as cadências características do modo Dórico, considera-se a tríade construída sobre o primeiro grau do modo e as tríades construídas sobre a nota lá (natural), que é a nota que torna o modo Dórico diferente do modo Eólio (seu modo menor padrão). O intervalo formado entre a nota do primeiro grau do modo (dó) e a nota lá (natural) é uma sexta maior. Portanto, a nota característica do modo Dórico é a sexta maior. A Figura 14 mostra as cadências musicais encontradas no modo Dórico, após o descarte de sua tríade diminuta:

$$
\begin{aligned}
& \text { Im - IIm - Im } \rightarrow \text { Cadência primária do modo Dórico } \\
& \text { Im - IV - Im } \rightarrow \text { Cadência secundária do modo Dórico }
\end{aligned}
$$

Figura 14. Cadências musicais encontradas para o modo Dórico. 
Os acordes encontrados nas cadências ilustradas na Figura 14 foram: "dó menor" (primeiro grau da escala), "ré menor" (segundo grau da escala) e "fá maior" (quarto grau da escala), cujas cifras são "Cm", "Dm" e "F", respectivamente. Os trechos musicais construídos sobre o modo Dórico, empregados no presente estudo, possuíam, portanto, uma melodia construída sobre as notas "dó, ré, mi bemol, fá, sol, lá e si bemol” (escala do modo Dórico), com uma harmonia construída sobre as cadências musicais descritas na Figura 14.

\section{Modo Frígio}

A Figura 15 mostra as tríades encontradas sobre a escala do modo Frígio.

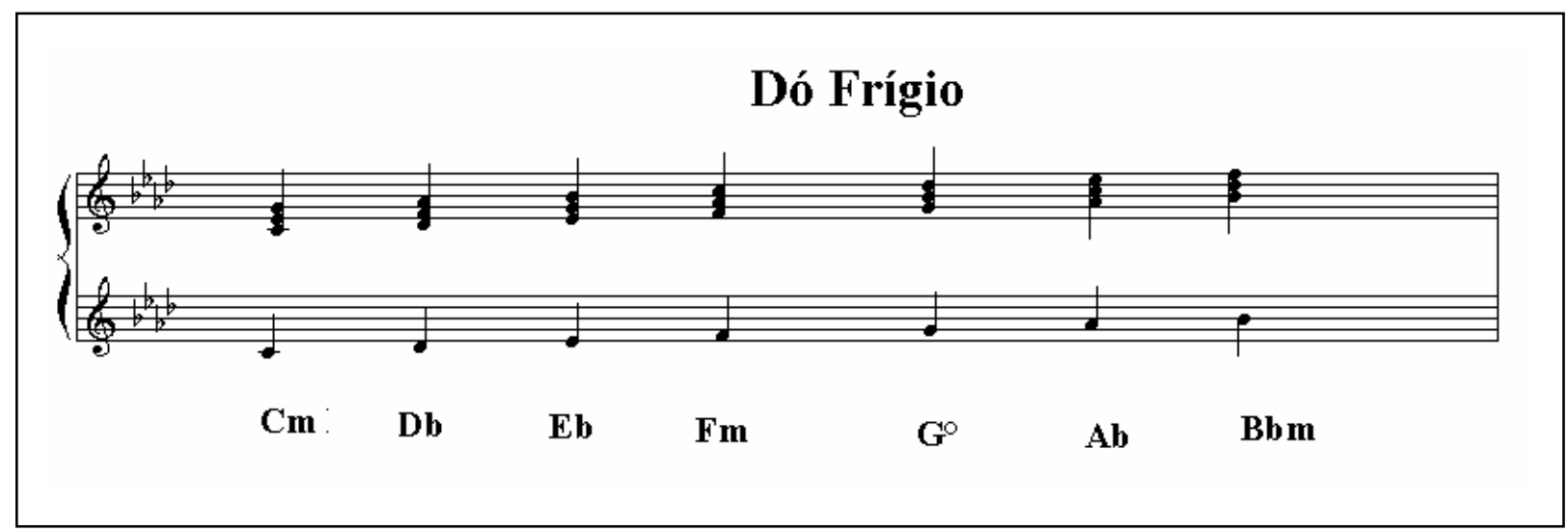

Figura 15. Tríades encontradas sobre a escala do modo Frígio.

De acordo com os critérios estabelecidos por Persichetti (1996), para se encontrarem as cadências características do modo Frígio, considera-se a tríade construída sobre o primeiro grau do modo e as tríades construídas sobre a nota ré bemol, que é a nota que torna o modo Frígio diferente do modo Eólio. O intervalo formado entre a nota do primeiro grau do modo (dó) e a nota ré bemol é uma segunda menor. Portanto, a nota 
característica do modo Frígio é a segunda menor. A Figura 16 mostra as cadências musicais encontradas no modo Frígio, após o descarte de sua tríade diminuta:

$$
\begin{aligned}
& \text { Im }- \text { bII }- \text { Im } \rightarrow \text { Cadência primária do modo Frígio } \\
& \operatorname{Im}-\text { bVIIm }- \text { Im } \rightarrow \text { Cadência secundária do modo Frígio }
\end{aligned}
$$

Figura 16. Cadências musicais encontradas para o modo Frígio.

Os acordes encontrados nas cadências ilustradas na Figura 16 foram: "dó menor" (primeiro grau da escala), "ré bemol maior" (segundo grau da escala) e "si bemol menor" (sétimo grau da escala), cujas cifras são "Cm”, "Dbm” e "Bbm”, respectivamente. Os trechos musicais construídos sobre o modo Frígio, empregados no presente estudo, possuíam, portanto, uma melodia construída sobre as notas “dó, ré bemol, mi bemol, fá, sol, lá bemol e si bemol" (escala do modo Frígio), com uma harmonia construída sobre as cadências musicais descritas na Figura 16.

\section{Modo Lócrio}

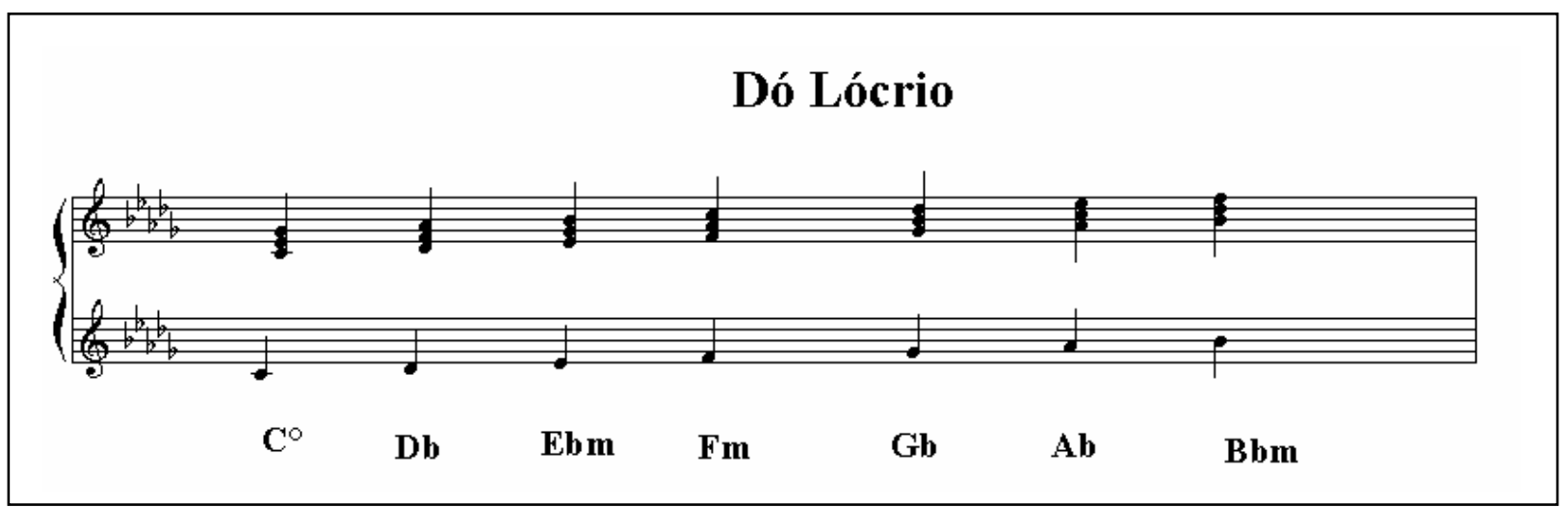

Figura 17. Tríades encontradas sobre a escala do modo Lócrio.

A Figura 17 mostra as tríades encontradas sobre a escala do modo Lócrio. 
De acordo com os critérios estabelecidos por Persichetti (1996), o modo Lócrio precisa ser adaptado. Como, neste modo, a tríade diminuta se encontra logo no primeiro acorde, esta precisa ser alterada para uma tríade maior ou menor, porque, além de a tríade diminuta ser descartada, o primeiro grau é obrigatório para todas as cadências principais modais, conforme tais critérios. Como o modo Lócrio possui uma terça menor em sua escala (e não uma terça maior), a tríade diminuta, encontrada no primeiro grau deste modo, foi substituída por uma tríade menor. Portanto, após esta adaptação, para se encontrarem as cadências características do modo Lócrio, considera-se a tríade construída sobre o primeiro grau do modo (agora menor) e as tríades construídas sobre as notas ré bemol e sol bemol, que são as notas que tornam o modo Lócrio diferente do modo Eólio. Os intervalos formados entre as notas do primeiro grau do modo (dó) e as notas ré bemol e sol bemol são uma segunda menor e uma quinta diminuta, respectivamente. Portanto, as notas características do modo Lócrio são a segunda menor e a quinta diminuta. A Figura 18 mostra as cadências musicais encontradas no modo Lócrio:

$$
\begin{gathered}
\text { Im }- \text { bII }- \text { Im } \rightarrow \text { Cadência ocorrida em ambos os modos (Lócrio e Frígio) } \\
\text { Im }- \text { bIIIm }-\operatorname{Im} \rightarrow \text { Cadência primária do modo Lócrio } \\
\text { Im }- \text { bVIIm }- \text { Im } \rightarrow \text { Cadência ocorrida em ambos os modos (Lócrio ou Frígio) } \\
\operatorname{Im}-\text { bV }- \text { Im } \rightarrow \text { Cadência secundária do modo Lócrio }
\end{gathered}
$$

Figura 18. Cadências musicais encontradas para o modo Lócrio.

Os acordes encontrados nas cadências ilustradas na Figura 18 foram: "dó menor" (primeiro grau da escala), "ré bemol maior" (segundo grau da escala), "si bemol menor" (sétimo grau da escala), "mi bemol menor" (terceiro grau da escala) e "sol bemol maior" (quinto grau da escala), cujas cifras são "Cm", "Dbm”, “Bbm”, "Ebm” e "Gb", 
respectivamente. No entanto, conforme a Figura 18, duas das cadências do modo Lócrio são idênticas às cadências encontradas no modo Frígio. Para que o modo Lócrio não soe de forma idêntica ao modo Frígio (caracterizando ainda mais a sonoridade do modo Lócrio), o uso dessas duas cadências em comum foi evitado, dando-se prioridade às cadências encontradas apenas no modo Lócrio (cadências Lócrias primária e secundária). Portanto, os trechos musicais construídos sobre o modo Lócrio, empregados no presente estudo, possuíam uma melodia construída sobre as notas "dó, ré bemol, mi bemol, fá, sol bemol, lá bemol e si bemol" (escala do modo Lócrio), com uma harmonia construída sobre as cadências musicais primárias descritas na Figura 18.

Os critérios estabelecidos por Persichetti (1996), bem como as linhas melódicas dos trechos musicais modais (vide Apêndices $C$ e $D$ do presente trabalho) foram adotados para que todos os trechos musicais utilizados como estímulos neste estudo conservassem o máximo possível de suas sonoridades típicas. Assim, cada trecho musical procurou explorar ao máximo a(s) sua(s) nota(s) característica(s). As partituras e o $\mathrm{CD}$, em mp3, com as gravações dos 63 trechos musicais utilizados no presente estudo, encontram-se nos Apêndices C e D deste trabalho, respectivamente.

Procedimento: o procedimento foi o mesmo utilizado no Experimento I, com exceção dos trechos musicais: ao invés das músicas do repertório erudito ocidental, foram apresentados 63 trechos musicais modais compostos pelo próprio experimentador, divididos em três lotes experimentais. Cada lote experimental continha 21 trechos musicais pertencentes aos sete modos (Jônio, Dórico, Frígio, Lídio, Mixolídio, Eólio e Lócrio) e aos três andamentos (Adágio, Moderato e Presto) analisados. O que variava, de um lote para o outro, era a situação em que cada trecho musical (composições 1, 2 e 3) foi apresentado. Por exemplo: no Lote I, aparecia a composição 1, no andamento Adágio, no modo Jônio; no Lote II, aparecia a 
composição 2, no andamento Adágio, no modo Jônio; no Lote III, aparecia a composição 3, no andamento Adágio, no modo Jônio; no Lote I, aparecia a composição 2, no andamento Moderato, no modo Dórico; no Lote II, aparecia a composição 3, no andamento Moderato, no modo Dórico; no Lote III, aparecia a composição 1, no andamento Moderato, no modo Dórico, e assim por diante, sempre balanceando a situação em que as composições apareciam com os outros modos e andamentos.

Cada sessão experimental durou, em média, 28 minutos.

Análise dos dados: a análise de dados foi feita de maneira similar àquela realizada no Experimento I:

1) um teste Chi-Quadrado foi aplicado para calcular as porcentagens das associações a cada categoria emocional entre grupos (Músicos x Não músicos); em caso de diferenças estatísticas significativas, uma Correlação de Spearman foi utilizada no intuito de verificar as diferenças de associação emocional a cada trecho musical entre os grupos;

2) um Teste do Sinal também foi aplicado para comparar as diferenças dos percentuais das associações emocionais de cada trecho musical apresentado entre os participantes músicos e não músicos;

3) índices de arousal e valência afetiva foram calculados para cada associação emocional entre grupos;

4) além dessa análise similar ao Experimento I, em decorrência das variáveis independentes utilizadas neste estudo (modo $\mathrm{x}$ andamento), uma análise de variância (ANOVA) foi aplicada para avaliar oscilações nos níveis de arousal e de valência afetiva, paralela às manipulações de modo e de andamento. 


\subsubsection{RESULTADOS}

A Tabela 5 ilustra as porcentagens das emoções associadas por músicos e não músicos a trechos musicais apresentados em diferentes modos e andamentos musicais. A maioria dos trechos musicais foi associada a uma emoção dominante (específica), para ambos os grupos. Considerou-se uma emoção dominante quando uma mesma emoção, para determinado trecho musical, apontou índices de escolha maior que 50\% pelos participantes. No entanto, alguns trechos não foram associados somente a uma única emoção (três casos no grupo Músicos e dois casos no grupo Não Músicos).

De maneira geral, as emoções Alegria, Serenidade e Tristeza foram escolhidas com mais freqüência (com média percentual de $29 \%, 29 \%$ e 25,7\%, respectivamente, para o grupo Músicos e 27,1\%, 30,6\% e 24,1\% para o grupo Não Músicos). A categoria Medo/Raiva foi escolhida com a média percentual de $16,4 \%$ para o grupo Músicos e de $18,1 \%$ para o grupo Não Músicos.

As correlações destas porcentagens para ambos os grupos indicaram que os percentuais mais antagonicamente correlacionados foram os de Alegria e Tristeza [r (20) = $0.77 \mathrm{p}<.001]$ em Músicos, e [r (20) = - 0.66, p < 0,001] em Não músicos, o que sugere que estas duas emoções foram as mais contrastantes, neste experimento.

O teste Chi-Quadrado e uma Correlação de Spearman mostraram que ocorreu dependência das associações emocionais entre grupos apenas para os trechos musicais 6 (modo Dórico, andamento presto), 10 (modo Lídio, andamento largo), 13 (modo Mixolídio, andamento largo), 16 (modo Eólio, andamento largo) e 19 (modo Lócrio, andamento largo), ou seja, os julgamentos emocionais destes trechos musicais dependeram do fato de o participante ser músico ou não-músico. Para todos os demais trechos musicais, o teste Chi- 
Quadrado mostrou que não existiram diferenças estatísticas significativas das categorizações emocionais entre os dois grupos de participantes. Assim, para os demais trechos musicais, a emoção associada independeu do fato de o participante ser músico ou não-músico.

Tabela 5. Porcentagens das emoções associadas por músicos e não músicos a trechos musicais apresentados em diferentes modos e andamentos musicais. Os trechos não associados a uma emoção específica estão entre parênteses.

\begin{tabular}{|c|c|c|c|}
\hline & \multicolumn{3}{|c|}{ Músicos } \\
\hline Lídio & Tristeza $(56,7 \%)$ * & Serenidade $(63,3 \%)$ & Alegria (90\%) \\
\hline Mixolídio & Tristeza $(53,3 \%)$ * & Serenidade $(66,7 \%)$ & Alegria $(80 \%)$ \\
\hline Dórico & Tristeza $(56,7 \%)$ & Serenidade (60\%) & Alegria $(73,3 \%)$ * \\
\hline Eólio & Tristeza $(53,3 \%)$ * & Serenidade $(46,7 \%)$ * & Alegria $(53,3 \%)$ * \\
\hline Lócrio & \multicolumn{3}{|c|}{ Não Músicos } \\
\hline \multirow[t]{2}{*}{ Modo } & \multicolumn{3}{|c|}{ Andamento } \\
\hline & 72 & 108 & 184 \\
\hline Lídio & Serenidade $(63,3 \%)$ * & Serenidade $(56,7 \%))$ & Alegria (80\%) \\
\hline Jônio & Serenidade $(70 \%)$ & Alegria $(66,7 \%)$ & Alegria $(100 \%)$ \\
\hline Mixolídio & Serenidade $(70 \%)$ * & Serenidade $(50 \%)$ & Alegria $(83,3 \%)$ \\
\hline
\end{tabular}

* Indicam diferenças estatísticas significantes entre respostas emocionais de músicos e não músicos.

A Tabela 5 sugere que, de forma geral, a Alegria esteve associada ao andamento presto e a Tristeza esteve associada ao andamento adágio, para ambos os grupos. Conforme o aumento do andamento, os trechos musicais tenderam a ser associados à Serenidade ou à Alegria, dependendo do modo considerado. Esta tendência foi encontrada para todos os modos, exceto para os modos Frígio e Lócrio; nestes casos, o aumento do andamento proporcionou a associação dos trechos musicais à categoria emocional Medo/Raiva, principalmente para o grupo Não Músicos.

No entanto, os dados da Tabela 5 também sugerem ambigüidades em algumas respostas emocionais, com alguns trechos musicais associados a diferentes emoções. Por exemplo, os músicos associaram o modo Frígio, em andamento moderato, a três categorias emocionais: Serenidade (33,3\%), Tristeza (33,3\%) e Medo/Raiva (30\%). 
Considerando as exposições dos trechos musicais no andamento Adágio, não foram encontradas diferenças estatísticas significativas entre as respostas emocionais dos músicos e não músicos para os modos Jônio (associado à emoção Serenidade), Dórico e Frígio (associados à emoção Tristeza). No entanto, diferenças estatísticas foram encontradas para os modos Lídio, Mixolídio, Eólio e Lócrio, com relação às associações emocionais entre grupos, no andamento adágio:

- o modo Lídio foi associado à Tristeza pelo grupo Músicos e à Serenidade pelo grupo Não Músicos $\left(X^{2}(3)=9,03 ; p=0,029\right.$, com correlação de Spearman $=-0,373 ; p=$ $0,03)$

- o modo Mixolídio foi associado à Tristeza pelo grupo Não Músicos e à Serenidade pelo grupo Músicos $\left(\mathrm{X}^{2}(3)=14,09 ; \mathrm{p}=0,03\right.$, com correlação de Spearman $=$ $0,43 ; p=0,01)$

- o modo Eólio foi associado à Tristeza para ambos os grupos; no entanto, diferenças estatísticas foram estabelecidas entre grupos, referentes às porcentagens encontradas: $53,3 \%$ das respostas dos músicos contra $83 \%$ das respostas dos não músicos $\left(X^{2}(2)=6,25 ; p=0,04\right.$, com correlação de Spearman $\left.=-0,03 ; p=0,822\right)$;

- o modo Lócrio foi associado à Tristeza para o grupo Músicos e a Medo ou Raiva para o grupo Não Músicos $\left(\mathrm{X}^{2}(3)=8,8 ; \mathrm{p}=0,032\right.$, com correlação de Spearman $=$ $0,089 ; p=0,049)$.

Considerando as exposições dos trechos musicais no andamento moderato, não foram encontradas diferenças estatísticas entre as associações emocionais de ambos os grupos para os modos Lídio, Mixolídio e Dórico (associados à Serenidade), Jônio (associado à Alegria) e Frígio (não sendo associado a uma emoção específica), para ambos os grupos. No 
entanto, diferenças estatísticas foram encontradas entre grupos para os modos Eólio e Lócrio, no andamento moderato;

- o modo Eólio foi associado à emoção Serenidade pelo grupo Músicos e associado à emoção Tristeza pelo grupo Não Músicos $\left(X^{2}(3)=7,3 ; p=0,063\right.$, com correlação de Spearman $=0,02 ; \mathrm{p}=0,046)$;

- o modo Lócrio não foi associado a uma emoção específica para os músicos, mas foi associado à categoria emocional Medo/Raiva para os não músicos $\left(\mathrm{X}^{2}(3)=7,5 ; \mathrm{p}=\right.$ 0,039, com correlação de Spearman =0,304; $\mathrm{p}=0,047$ ).

Considerando as exposições musicais dos trechos musicais no andamento presto, não foram encontradas diferenças estatísticas significativas entre as associações emocionais de ambos os grupos para os modos Lídio, Jônio, Mixolídio (associados à Alegria) e Lócrio (associado à Medo/Raiva). No entanto, diferenças estatísticas foram encontradas entre os grupos para os modos Dórico, Eólio e Frígio:

- o modo Dórico foi associado a uma mesma emoção (Alegria) para ambos os grupos; no entanto, diferenças estatísticas foram encontradas dentro das porcentagens das respostas emocionais associadas a este modo, com $73,3 \%$ de respostas para o grupo Músicos contra 43,3\% de respostas para o grupo Não Músicos $\left(X^{2}(3)=8,41 ; p=0,38\right.$, com correlação de Spearman $=0,03 ; p=0,02)$

- o modo Eólio foi associado à Alegria pelo o grupo Músicos e não foi associado a uma emoção específica para o grupo Não Músicos $\left(X^{2}(3)=3,04 ; p=0,03\right.$, com correlação de Spearman $=0,29 ; p=0,037)$;

- e, finalmente, o modo Frígio, não foi associado a nenhuma emoção específica pelo grupo Músicos, mas associado à categoria emocional Medo/Raiva pelo grupo Não Músicos $\left(X^{2}(3)=3,46 ; p=0,032\right.$, com correlação de Spearman $\left.=0,051 ; p=0,042\right)$. 
Como no experimento I do presente trabalho, os dados deste experimento foram reorganizados em pares, em função dos níveis de arousal e valência afetiva encontrados. Assim, respostas emocionais de Alegria foram substituídas pelo par $(1,1)$, respostas emocionais de Serenidade foram substituídas pelo par $(-1,1)$, respostas da categoria emocional Medo/Raiva foram substituídas pelo par $(1,-1)$ e, finalmente, respostas emocionais de Tristeza foram substituídas pelo par $(-1,-1)$. Este tipo de análise possibilitou o cálculo de um valor médio de arousal e de valência afetiva para cada uma das 21 condições testadas neste experimento (3 andamentos x 7 modos), para ambos os grupos (Músicos x Não músicos).

A Figura 19 mostra os valores médios de arousal e de valência afetiva de ambos os grupos, em função do modo e do andamento musical, obtidos por meio das associações emocionais dos participantes aos trechos musicais empregados. A Figura 19 confirma algumas das tendências que foram exibidas na Tabela 5: houve um efeito da interação "modo x andamento" nas respostas emocionais de ambos os grupos. Conforme o aumento do andamento, as emoções tenderam a ser mais positivas, com valores de arousal mais altos. Este efeito foi modulado pelas características emocionais do modo musical. 

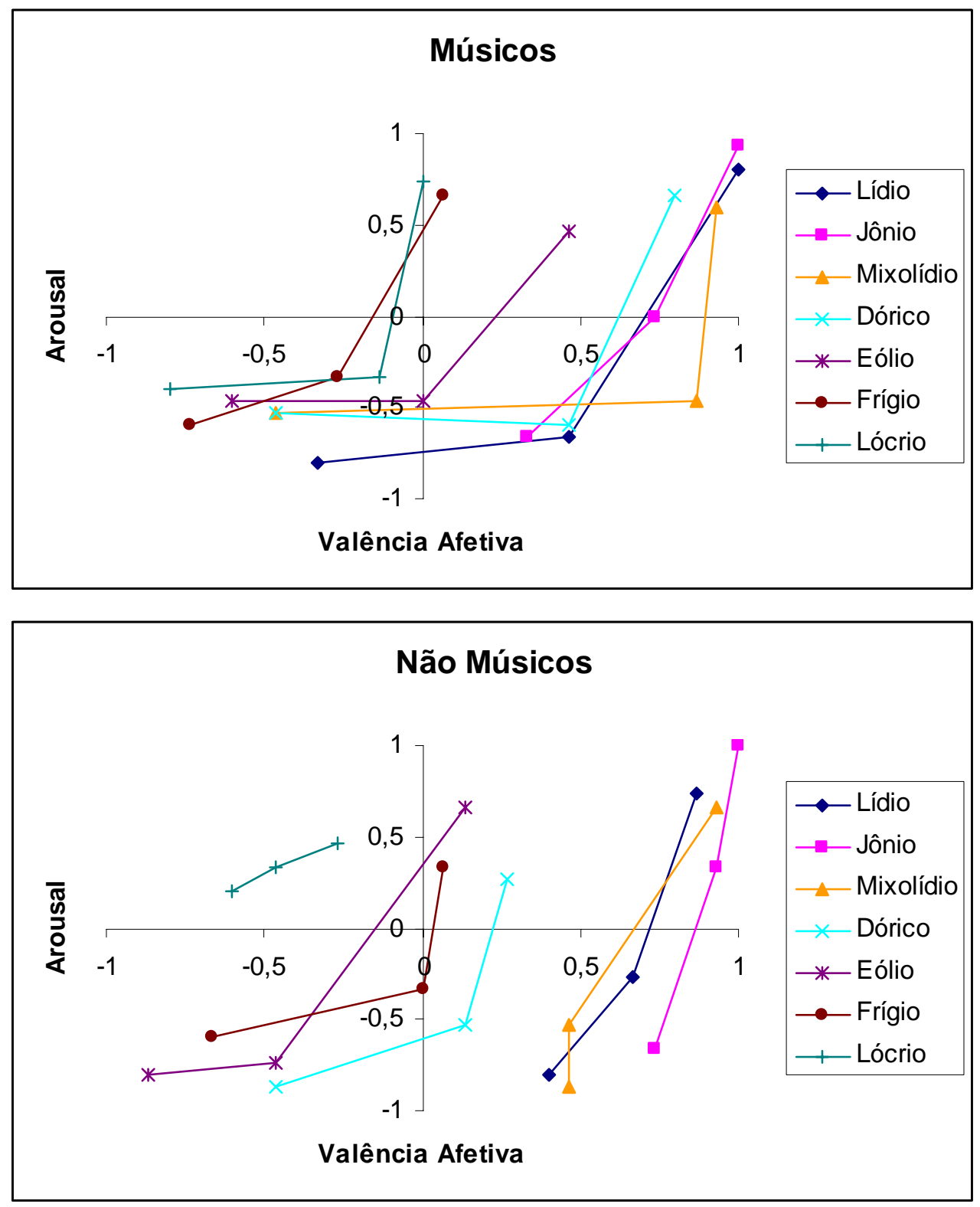

Figura 19. Valores de arousal e valência afetiva das associações emocionais de músicos e não músicos aos trechos musicais com variação do modo e do andamento musical. A ordem em que os modos aparecem na legenda está disposta conforme a hierarquia modal de Wisnik (2004).

A Figura 19 mostra que, para todos os modos, houve um aumento do arousal, paralelo ao aumento do andamento musical. Dessa forma, para todos os modos, os andamentos presto tiveram índices de arousal maiores do que os andamentos moderato, que, por sua vez, tiveram índices de arousal maiores do que os andamentos adágio. Conclui-se, portanto, que o andamento foi o modulador do arousal, tratando-se de trechos musicais modais empregados neste estudo, para ambos os grupos. 
Analisando a interação de cada modo musical sobre os andamentos, separadamente, temos a seguinte configuração, para ambos os grupos:

1) Modo Lídio: no andamento adágio, para o grupo Músicos, obteve índices de arousal e de valência afetiva negativos, enquanto para o grupo Não Músicos obteve índice de arousal negativo e valência afetiva positiva; no andamento moderato, para ambos os grupos, obteve índices de arousal negativo e de valência afetiva positiva (com maior índice de arousal para o grupo Não Músicos); no andamento presto, para ambos os grupos, obteve índices de arousal e valência afetiva positivos (com índices maiores de ambas as dimensões para o grupo Músicos);

2) Modo Jônio: no andamento adágio, para ambos os grupos, obteve índices de arousal negativo e de valência afetiva positiva (com maior índice de valência afetiva positiva para o grupo Não Músicos); no andamento moderato, para o grupo Músicos, obteve índices de arousal neutro (igual a zero) e de valência afetiva positiva, enquanto para o grupo Não Músicos obteve índices de arousal e de valência afetiva positivos; no andamento presto, para ambos os grupos, obteve índices de arousal e valência afetiva positivos, sendo, inclusive, o modo que alcançou o maior índice possível dentro destas duas dimensões para o grupo Músicos;

3) Modo Mixolídio: no andamento adágio, para o grupo Músicos, obteve índices de arousal e de valência afetiva negativos, enquanto para o grupo Não Músicos obteve altos índices de arousal negativo e de valência afetiva positiva; no andamento moderato, para ambos os grupos, este modo obteve índices de arousal negativo e índices de valência afetiva positiva, sendo que, no grupo Não Músicos, foi o modo que teve os índices mais altos de valência afetiva obtidos neste andamento; no andamento presto, para ambos os grupos, foram encontrados índices de arousal e valência afetiva positivos; 
4) Modo Dórico: este modo obteve, nos três andamentos, índices de arousal e valência positiva semelhante, entre os grupos. No entanto, os maiores índices foram sempre para o grupo Músicos: no andamento adágio, foram encontrados índices de arousal e de valência afetiva negativos; no andamento moderato, índices de arousal negativo e valência afetiva positiva; no andamento presto, índices de arousal e valência afetiva positivos (no entanto, ambos os índices foram sempre equivalentes ou mais baixos do que os índices obtidos para os modos Lídio, Jônio e Mixolídio, independente do andamento considerado);

5) Modo Eólio: no andamento adágio, para ambos os grupos, obteve índices de arousal e de valência afetiva negativa (com maiores índices para o grupo Não Músicos); no andamento moderato, para o grupo Músicos, foram encontrados índices de arousal negativo e valência afetiva neutra (igual a zero), enquanto para o grupo Não Músicos, índices de arousal e valência afetiva negativos; no andamento presto, para ambos os grupos, foram encontrados índices de arousal e valência afetiva positivos (com maiores índices de arousal para o grupo Não Músicos e maiores índices de valência afetiva para o grupo Músicos);

6) Modo Frígio: assim como no modo Dórico, este modo obteve, nos três andamentos, índices de arousal e valência afetiva positivos semelhantes entre os grupos. Para ambos os grupos, no andamento adágio, o modo Frígio obteve índices de arousal e de valência afetiva negativos; no andamento moderato, para o grupo Músicos, obteve índices de arousal e de valência afetiva negativos, enquanto para o grupo Não Músicos, índices de arousal negativo e de valência afetiva neutra (igual a zero); no andamento presto, para ambos os grupos, foram encontrados índices de arousal e de valência afetiva positivos (porém, com valência afetiva quase neutra);

7) Modo Lócrio: para o grupo Músicos, no andamento adágio, obteve índices de arousal e de valência afetiva extremamente negativos; no andamento moderato, obteve 
índice de arousal negativo e índice de valência afetiva negativa (quase neutra); no andamento presto, obteve índices de arousal positivo e valência afetiva neutra (igual a zero). No entanto, para o grupo Não Músicos, nos três andamentos, obteve índices de arousal positivo e valência afetiva negativa, com o nível de ambos os índices crescendo paralelamente ao aumento do andamento.

Para avaliar as alterações do arousal em função das manipulações de modo e andamento, uma análise de variância com delineamento experimental 3 (andamentos) x 7 (modos) x 2 (grupos de sujeitos) foi empregada, com os dois primeiros fatores sendo considerados intergrupos e o último fator sendo considerado entre grupos. A Figura 20, a seguir, ilustra os índices de arousal em função dos modos e dos andamentos analisados nos trechos musicais empregados no estudo. 

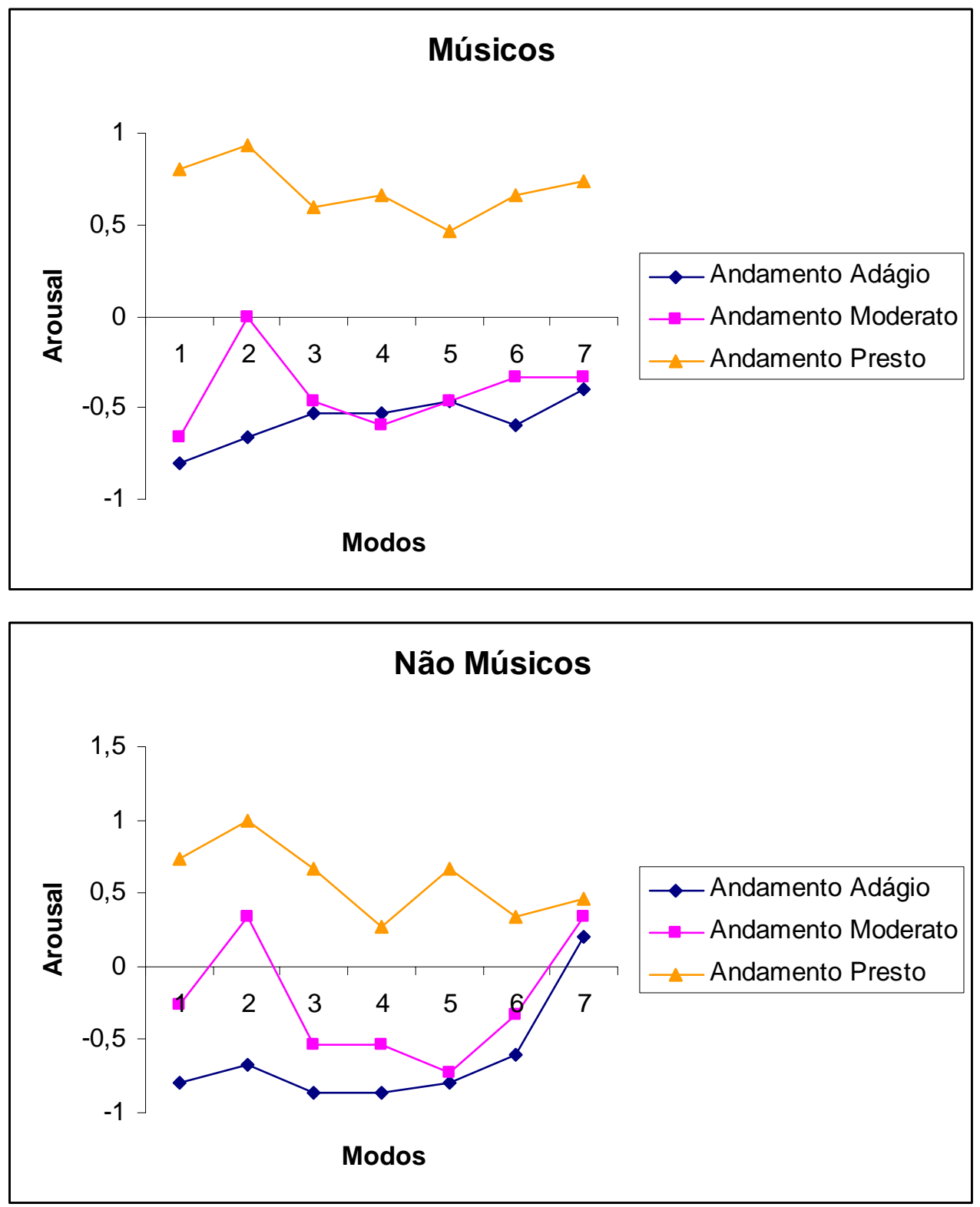

Figura 20: O efeito do modo e do andamento musical sobre o arousal, em músicos e não músicos. Os números indicam os modos, organizados conforme a hierarquia modal de Wisnik (2004): 1. Lídio; 2. Jônio; 3. Mixolídio; 4. Dórico; 5. Eólio; 6. Frígio; 7. Lócrio.

Os dados da Figura 20 mostram que houve um efeito significativo do andamento sobre o arousal $[\mathrm{F}(2,116)=268,62 ; \mathrm{MSE}=0,6676 ; \mathrm{p}<0,001]$, com índices mais elevados de arousal para as associações emocionais referentes ao andamento presto (com uma média de valores - 0,6, - 0,328. e - 0,642 para os andamentos adágio, moderato e presto, respectivamente). As diferenças estatísticas foram encontradas, principalmente, quando os valores de arousal do andamento adágio, em diferentes modos, foram comparados 
com os valores de arousal do andamento presto, em diferentes modos $[\mathrm{F}(1,58)=429,73$, MSE $=0,755, p<0,001]$. No entanto, também foram encontradas diferenças estatísticas quando os níveis de arousal dos andamentos adágio e moderato foram comparados em diferentes modos $[\mathrm{F}(1,58)=23,43, \mathrm{MSE}=0,6602] . \mathrm{O}$ efeito do arousal sobre o andamento musical foi ligeiramente modulado pela expertise musical $[\mathrm{F}(6348)=2,62, \mathrm{MSE}=0,6657, \mathrm{p}$ $<0,02]$, com o grupo Músicos sendo menos sensível a mudanças de andamento (do adágio ao moderato) ocorridas dentro de um mesmo modo musical em relação ao grupo Não Músicos.

A ANOVA também revelou um efeito significativo do arousal sobre o modo musical $[\mathrm{F}(6348)=8,71 ; \mathrm{MSE}=0,6657, \mathrm{p}<0,001]$, modulado pelo andamento, $[\mathrm{F}(12,696)$ $=3,60, \mathrm{MSE}=0,6196, \mathrm{p}<0,001]$ e com pouca influência da expertise musical $[\mathrm{F}(6,348)=$ 2,62, $\operatorname{MSE}=0,6657, \mathrm{p}<0,02]$. A partir desta análise, o modo com maior nível de arousal foi o modo Jônio, para ambos os grupos $[\mathrm{F}(1,58)=25,98, \mathrm{MSE}=0,5082, \mathrm{p}<0,001]$. O segundo valor mais alto de arousal foi encontrado para o modo Lócrio (para o grupo Não Músicos) $[\mathrm{F}(1,58)=25,60, \mathrm{MSE}=0,9778, \mathrm{p}<0,001]$. Não foram encontradas diferenças estatísticas entre os valores de arousal dos modos Lídio, Mixolídio, Dórico e Eólio, para ambos os grupos. Comparando os níveis de arousal de todos os modos nos andamentos adágio e moderato, diferenças expressivas foram encontradas apenas para os modos Jônio (ambos os grupos) e Lócrio (para o grupo Não Músicos). Em contraste, os níveis de arousal dos outros modos (Lídio, Mixolídio, Dórico, Eólio e Frígio) cresceram somente quando estes modos foram apresentados em andamento presto.

Para verificar a influência do modo e do andamento musical sobre a valência afetiva dos trechos musicais associados, foi feita uma análise de variância semelhante à análise anterior. Os dados se encontram na Figura 21: 

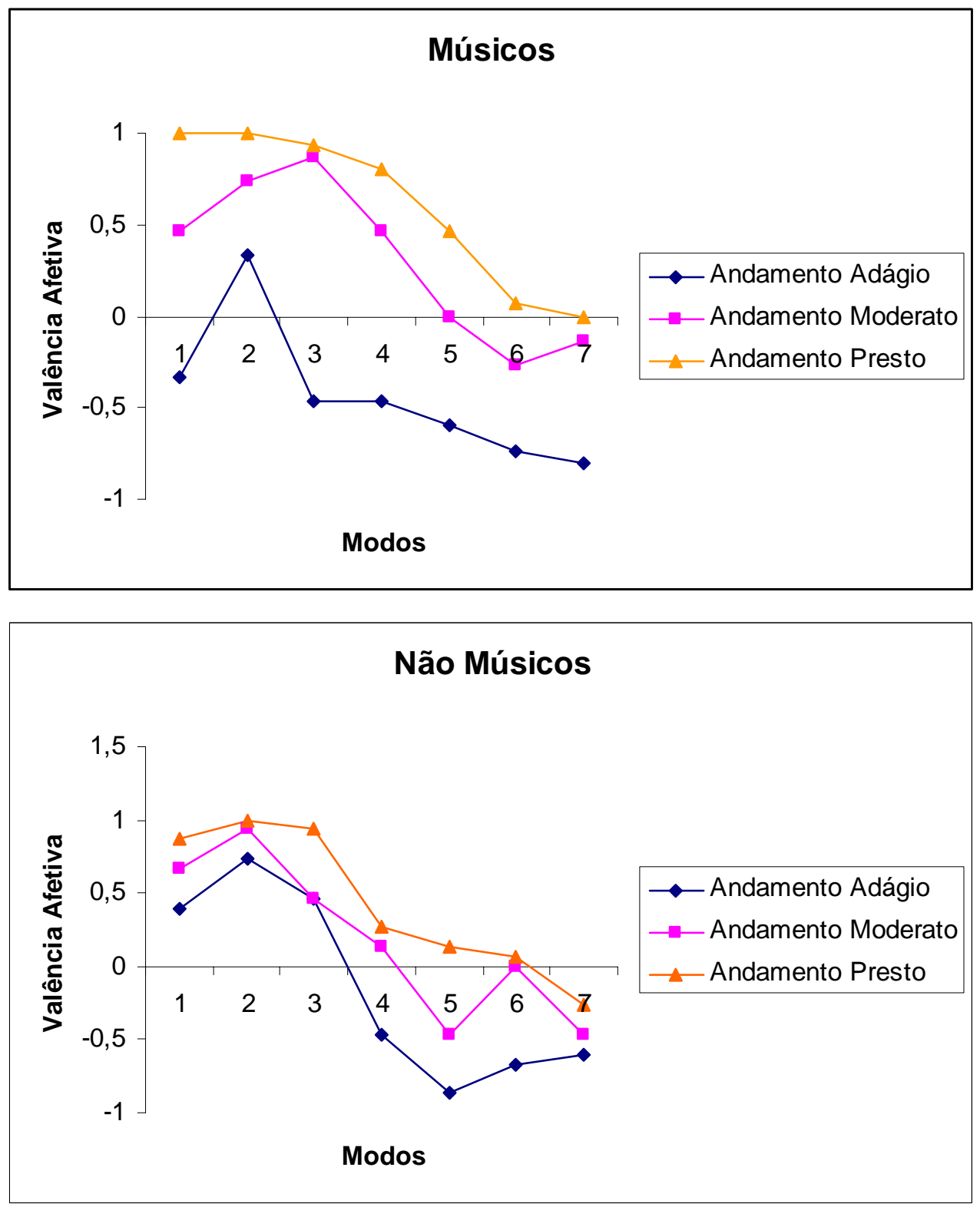

Figura 21: O efeito do modo e do andamento musical sobre a valência afetiva em músicos e não músicos. Os números indicam os modos, organizados conforme a hierarquia modal de Wisnik (2004): 1. Lídio; 2. Jônio; 3. Mixolídio; 4. Dórico; 5. Eólio; 6. Frígio; 7. Lócrio.

De acordo com os dados exibidos na Figura 21, os valores de valência afetiva mudaram consideravelmente, conforme o modo e o andamento apresentados. Para avaliar as diferenças estatísticas sobre estas mudanças, uma análise de variância com delineamento experimental 3 (andamentos) x 7 (modos) x 2 (grupos de sujeitos) foi empregada, com os dois primeiros fatores sendo considerados intergrupos e o último fator sendo considerado entre grupos. 
A Figura 21 mostra que houve um efeito significativo do andamento musical na valência afetiva $[\mathrm{F}(2116)=84,81, \operatorname{MSE}=0,8385, \mathrm{p}<0,001]$. Valências negativas estiveram associadas ao andamento adágio (- 0,29), porém, aos poucos, os níveis destas valências foram se tornando positivos, conforme o andamento foi aumentando, do moderato para o presto $(0,24$ e 0,52 , respectivamente). Este efeito do andamento foi mais pronunciado no grupo Músicos, conforme indicado pela interação andamento x expertise musical [F (2, $116)=8,46, \operatorname{MSE}=0,8385 ; \mathrm{p}<0,001]$. Houve também um efeito significativo do modo musical na valência afetiva, $[\mathrm{F}(6,348)=56,21, \mathrm{MSE}=0,6764, \mathrm{p}<0,001]$, que foi modulado pela expertise musical $[\mathrm{F}(6,348)=4,24, \mathrm{MSE}=0,6764, \mathrm{p}<0,001]$. Conforme o esperado, os três modos maiores (Lídio, Jônio e Mixolídio) foram associados aos maiores índices de valências positivas, para ambos os grupos, em comparação aos outros modos (menores).

A novidade apresentada pelos dados deste experimento é que pequenas mudanças na estrutura escalar dos modos foram suficientes para modular a valência afetiva das emoções percebidas durante a escuta musical. Os estudos realizados anteriormente, que procuraram verificar a influência do modo musical na percepção das emoções, foram realizados a partir da manipulação de apenas dois tipos de modos: um maior e outro menor. Neste estudo, foram utilizados sete modos, sendo três maiores e quatro menores. Assim, estes dados nos permitiram inferir a existência de uma linearidade nos níveis de valência afetiva das emoções percebidas durante uma escuta musical. O modo musical pode, portanto, ser usado como uma propriedade estrutural da música responsável por oscilações dos níveis de valência afetiva dos trechos musicais a serem empregados em estudos sobre as emoções musicais.

Uma análise de contrastes revelou uma tendência significativa linear do modo sobre a valência afetiva $[\mathrm{F}(1,58)=115,60, \mathrm{MSE}=0,6428, \mathrm{p}<0,001]$ que aponta para a mesma direção estabelecida pela hierarquia modal sugerida por Wisnik (2004): valências 
afetivas foram se tornando mais negativas conforme o aumento da "obscuridade", dentro desta hierarquia (vide Introdução, Figura 3, página 60). No entanto, tal hierarquia não foi totalmente confirmada, se considerarmos apenas os modos maiores, uma vez que o modo Jônico, para ambos os grupos, esteve associado a valências mais positivas que o modo Lídio, considerado o modo "mais claro" da hierarquia $[\mathrm{F}(1,58)=19,85$, MSE: 0,3498, p < 0,001]. Além disso, também não foram encontradas diferenças significativas entre os níveis de valência afetiva dos modos Lídio e Mixolídio. Com relação aos modos menores, a hierarquia de Wisnik (2004) foi claramente confirmada pelos não músicos participantes deste estudo, uma vez que os valores de valência afetiva foram se tornando cada vez mais negativos conforme as peças eram apresentadas nos modos Dórico, Eólio, Frígio e Lócrio, respectivamente. Esta tendência linear ocasionou diferenças estatísticas neste grupo $[\mathrm{F}(1,58)$ $=13,59, \operatorname{MSE}=0,7219, \mathrm{p}<0,001]$ e, em menor extensão, no grupo Músicos, $[\mathrm{F}(1,58)=$ 9,85, $\mathrm{MSE}=0,7219, \mathrm{p}<0,01]$. Neste último grupo, o modo Frígio esteve associado a níveis de valência afetiva mais negativos do que o modo Lócrio (não se encaixando, portanto, na hierarquia modal sugerida por Wisnik). Portanto, com relação aos músicos, os dados deste estudo sugerem duas permutações modais na referida hierarquia: Mixolídio, Jônio, Lídio, Dórico, Eólio, Lócrio e Frígio.

\subsubsection{DISCUSSÃO}

O presente estudo investigou o efeito do andamento e do modo musical sobre respostas emocionais de músicos e não músicos. Este assunto já foi abordado em vários estudos (HEVNER, 1935; DALLA BELLA et al., 2001a; DALLA BELLA et al., 2001b; WEBSTEIR; WEIR, 2005). De maneira geral, os dados aqui obtidos são coerentes com os resultados já obtidos nestes estudos: modos menores estiveram mais associados a valências 
afetivas negativas do que os modos maiores e este efeito foi modulado pelo andamento dos trechos musicais: andamentos mais rápidos resultaram em associações emocionais relacionadas a índices mais altos de arousal e índices de valência afetiva mais positivos. No entanto, os dados deste estudo mostraram que além da distinção "maior x menor" usualmente empregada nos estudos sobre as emoções musicais, pequenas alterações na estrutura escalar de outros modos musicais modularam as respostas emocionais dos músicos e dos não músicos. Tanto nos índices de arousal quanto nos índices de valência afetiva foram encontradas diferenças dentro de cada "nova categoria modal" inserida nos modos maiores (Lídio, Jônio e Mixolídio) e menores (Dórico, Eólio, Frígio e Lócrio). Isto demonstra que a diferença entre a primeira e a terceira nota do modo (intervalo de terça, que o caracteriza como sendo maior ou menor), não foi o único fator que determinou a expressão das emoções desencadeadas pelo modo durante uma escuta musical. Por exemplo, os modos Dórico e Eólio têm o mesmo intervalo entre a primeira e a terceira nota que compõem suas respectivas escalas (terça menor). $\mathrm{O}$ entanto, o intervalo de sexta difere um modo de outro: o modo Dórico possui um intervalo de sexta maior entre a primeira e a sexta nota do modo, enquanto no modo Eólio, este intervalo é de sexta menor. Os dados confirmaram que uma única diferença intervalar (sexta maior x sexta menor) foi o suficiente para modular a valência afetiva da emoção associada a estes modos. Um comentário similar pode ser feito para outros modos que diferem entre si por um único intervalo entre a primeira e quaisquer outras notas de suas respectivas escalas (por exemplo, entre os modos Jônio e Lídio, entre os modos Jônio e Mixolídio, ou entre os modos Frígio e Lócrio).

Estes resultados também são consistentes com o estudo de Ramos (2004), em relação aos modos Jônio, Eólio e Lócrio, em não músicos. Este autor mostrou que seqüências harmônicas apresentadas no modo Jônio obtiveram maiores índices de Alegria em relação a seqüências harmônicas apresentadas nos modos Eólio e Lócrio, respectivamente, 
demonstrando que mudanças sutis na estrutura intervalar de cada modo têm um efeito significativo sobre as emoções desencadeadas nos ouvintes durante a escuta musical. Esta constatação sugere que a bem estabelecida distinção “maior x menor", encontrada na literatura, é apenas um caso peculiar de um processo mais geral que rege as emoções musicais.

A característica mais crítica do uso de uma gama maior de modos em estudos sobre as emoções musicais é que eles são construídos a partir de uma nota de referência, cuja estrutura intervalar (determinada pela distância entre esta nota e as outras notas musicais que constituem cada escala), é diferente, de um modo para outro. Ou seja, os eventos musicais são percebidos em referência a um ponto cognitivo específico, que difere de um modo a outro. A importância dos pontos cognitivos de referência para a cognição musical já foi anteriormente abordada por Krumhansl (1990) para a música tonal ocidental. Esta autora mostrou que as alterações no ponto de referência cognitivo causadas por mudanças na tonalidade musical estão associadas a efeitos altamente expressivos na música tonal. O presente estudo estende esta conclusão à música modal, mostrando que modificações na nota de referência de um dado conjunto de notas musicais (como exemplo, mudanças no modo musical) são suficientes para modular associações emocionais dos ouvintes (músicos ou não músicos). Esta constatação enfatiza a organização cognitiva de respostas emocionais à música: se os participantes não percebessem a música modal em referência a um tom base, eles provavelmente não diferenciariam a emoção associada a cada modo com a mesma precisão.

Ouvintes ocidentais, fortemente aculturados à música tonal, provavelmente vivenciam este fenômeno durante suas escutas musicais. Alguns dos participantes músicos deste experimento relataram, nos questionários complementares, aplicados após o termino das tarefas experimentais, que, quando eles ouviam as melodias no modo Dórico pela primeira vez, geralmente tinham dificuldade para perceber a nota de referência. Assim, eles percebiam 
as melodias em referência à nota base do modo Jônio (maior padrão), que é a referência cognitiva habitual da música tonal (KRUMHANSL, 1990). Como conseqüência, estes participantes relataram que tiveram dificuldades para compreender a especificidade que difere a música modal da música tonal. Este dado sugere que a diferença de organização intervalar entre os modos que levou Wisnik (2004) a classificá-los hierarquicamente não seria relevante se ouvintes não percebessem os eventos musicais modais em referência a algum tom apropriado.

Os dados obtidos neste estudo sugerem não ser provável que sejam as diferenças psico-acústicas originadas nos intervalos de terça maior e de terça menor (que definem a distinção "maior x menor") os fatores responsáveis por discrepâncias sonoras da música (BREGMAN, 2000) e também não parece ser provável que estas diferenças se estendam a outros domínios tais como o discurso da fala (COSTA; FINE; BITTI, 2004; ROSS; CHOI; PURVES, 2007). Os dados deste experimento sugerem que o efeito do modo está enraizado a partir de uma mesma organização cognitiva que rege o efeito da tonalidade na música ocidental, ou seja, um evento musical é percebido a partir de uma referência a uma determinada "nota de base".

A segunda contribuição principal deste estudo foi a de investigar sistematicamente a contribuição mútua do modo e do andamento a respostas emocionais de arousal e de valência afetiva à música. Esta questão tem sido amplamente abordada em tarefas cognitivas, mas raramente foi investigada em relação à reação emocional. Webster e Weir (2005) relacionaram os efeitos interativos de alteração do modo e do andamento musical em respostas emocionais à música. Os resultados obtidos por estes autores mostraram que esta interação levou a um fenômeno bastante relevante: melodias em modo maior, não harmonizadas, e com um determinado aumento no andamento musical, foram associadas à Alegria, enquanto, nas mesmas condições, as melodias em modo menor foram associadas à 
Raiva. Este efeito interativo sugere que o andamento aumentou principalmente o índice de arousal da emoção musical: trechos musicais relacionados a valências afetivas positivas foram julgados como sendo "mais alegres" quando o arousal destes trechos aumentou. Em contrapartida, trechos musicais relacionados a valências afetivas negativas desencadearam Raiva quando o arousal aumentou, em decorrência do aumento do andamento musical. No entanto, os dados do presente estudo não replicaram uma interação similar entre o modo e o andamento musicais. Tal como ilustrado pela Figura 19, quando o andamento aumentou, houve um aumento tanto no arousal como na valência afetiva das associações emocionais dos ouvintes. Por essa via, os trechos musicais "tristes" tenderam a mover-se para a direita (que sugere a emoção Serenidade) dentro do espaço do modelo circumplexo de Russel (1980; vide item 1.2.3 da Introdução do presente trabalho). Além disso, uma notável consistência nos dados foi encontrada neste estudo: quando o andamento dos trechos musicais empregados aumentou do lento para o moderado, todos os modos tenderam a ser associados à Serenidade; quando o andamento dos mesmos trechos musicais aumentou de moderado para rápido, todos os modos tenderam a ser associados à Alegria. Estes efeitos estão claramente ilustrados na Tabela 5. A análise estatística reportou um efeito significativo do andamento e do modo apenas sobre a dimensão de arousal. Este efeito interativo foi causado principalmente porque um aumento sutil no andamento foi o suficiente para aumentar os índices de arousal dos modos Jônio e Lócrio (somente em não músicos), ou seja, em dois modos musicais bastante contrastantes, quase opostos, dentro da hierarquia modal sugerida por Wisnik (2004). Em suma, os dados aqui obtidos se encaixam melhor em um modelo mais aditivo do que interativo, sugerindo que o modo e o andamento musical contribuem de forma independente em respostas emocionais à música. Esta conclusão é coerente com os dados encontrados por Webster e Weir (2005) para melodias harmonizadas. O aprofundamento dessa investigação, 
em estudos futuros, poderá ocorrer a partir da análise sistemática de respostas emocionais a melodias modais não harmonizadas.

Os dados do presente estudo igualmente contribuíram para lançar luz sobre a influência da estrutura da experiência emocional no domínio musical. Apesar de haver um consenso no sentido de considerar as "emoções musicais de base" pertencentes a quatro grandes categorias (Alegria, Serenidade, Tristeza e Medo/Raiva), não fica claro se a experiência emocional pode ser satisfatoriamente avaliada por esta abordagem categórica da emoção. Pelo fato de cada uma destas quatro categorias emocionais principais estar localizada em pontos muito específicos do modelo circumplexo de Russel (1980), (cada categoria em um dos quatro quadrantes), um modelo bidimensional poderia dar conta de estender a questão a estudos mais refinados sobre as emoções musicais. Estes estudos utilizariam medidas de um maior número de emoções, que estariam embutidas dentro de cada um dos quatro espaços do modelo circumplexo de Russel (1980), ou seja, seriam mensuradas emoções derivadas das próprias categorias emocionais principais. Por exemplo: dentro da categoria Serenidade, outras categorias emocionais que sugerissem baixo grau de arousal e valência afetiva positiva poderiam ser mensuradas, como o "estar relaxado", o "estar tranqüilo", o "estar com sono", etc. e esta coerência poderia ser também estabelecida para os outros quadrantes do modelo de Russel (1980). Este modelo bidimensional postularia um grande número de emoções específicas a serem mensuradas durante a experiência de escuta musical. Assim, cada trecho musical apresentado desencadearia novos índices de arousal e de valência afetiva. Estes índices encontrados poderiam estar localizados em pontos em comum (ou muito próximos) de cada nova categoria emocional estabelecida a partir de cada subdivisão emocional de cada quadrante do modelo circumplexo. Isto determinaria, com mais precisão, a emoção específica relacionada a cada trecho musical apresentado aos ouvintes. Portanto, as chances de um 
mesmo trecho musical não estar associado a uma emoção específica diminuiriam, porque os ouvintes teriam uma gama maior de emoções a serem associadas.

O presente experimento não foi concebido no intuito de contrastar abordagens categóricas e dimensionais das emoções musicais. No entanto, assumiu-se aqui que a manipulação de alguns parâmetros musicais (como modo e andamento) ofereceria uma boa oportunidade para o direcionamento dessa questão. Além disso, se encararmos as emoções como sendo percebidas pertencentes a categorias, as respostas emocionais dos participantes deverão ser também de natureza categórica (ou seja, restritas a um conjunto de léxicos). E os participantes deste estudo relataram, nos questionários experimentais aplicados após o experimento, que alguns dos trechos não se relacionavam a nenhuma das quatro categorias emocionais analisadas e que, em algumas vezes, as suas respostas emocionais eram guiadas àquela emoção mais próxima possível de suas percepções. Isto sugere que manipulações realizadas nos estímulos musicais podem não ter um forte efeito sobre uma categoria emocional percebida, até certo ponto. Ainda na mesma direção, pequenas mudanças em estímulos musicais resultariam em mudanças na percepção apenas da categoria da emoção musical avaliada. Esta súbita mudança de categoria é típica da percepção categórica encontrada para fonemas (ROSS; CHOI; PURVES, 2007), bem como para intervalos musicais (COSTA, FINE; BITTI, 2004). No entanto, pelo menos em música, ainda não se sabe se os mesmos efeitos poderiam ser encontrados sobre um conjunto de emoções que se assemelham entre si por sugerirem índices de arousal e de valência afetiva semelhantes.

O direcionamento desta questão por meio da manipulação de vários modos e andamentos foi de interesse deste estudo, uma vez que ambos os parâmetros foram empregados para induzir emoções contrastantes como Alegria e Tristeza nos ouvintes. Uma abordagem bidimensional da emoção musical poderia prever, de forma mais abrangente, até que ponto as manipulações sobre um mesmo parâmetro de estímulos poderiam modular a 
percepção da emoção musical progressivamente ao longo de uma ou de outra dimensão emocional (arousal e valência afetiva). Os dados do presente estudo indicaram que Alegria e Tristeza não foram categorias emocionais que ocorreram com mais freqüência nas respostas emocionais dos ouvintes. Além disso, a Figura 19 apresenta algumas evidências de que a manipulação dos dois parâmetros envolvidos no presente estudo (modo e andamento musical) não resultou em alterações bruscas entre as duas categorias (Alegria e Tristeza): trechos musicais percebidos associados à Tristeza tenderam a serem associados à Serenidade antes de serem associados à Alegria, conforme o aumento do andamento e vice-versa. Dependendo da expressão específica de cada modo, esse efeito do andamento resultou em trajetórias que abrangeram diferentes pontos do espaço, dentro do modelo circumplexo de Russel (1980). A mensuração de emoções localizadas em pontos específicos a partir da subdivisão de cada quadrante do modelo circumplexo poderia estabelecer com mais precisão a emoção desencadeada durante a escuta de cada trecho musical. Finalmente, um modelo bidimensional de mensuração das emoções musicais poderia levar os compositores a induzir mais precisamente, no decorrer do evento musical, uma grande variedade de arousal e de valência afetiva em seus ouvintes.

Este estudo demonstrou que pequenas alterações no modo e no andamento musical foram o suficiente para modular o desencadeamento de emoções específicas em ouvintes músicos e não músicos. A próxima etapa do presente trabalho consiste em submeter os trechos modais com variação de andamento, utilizados neste experimento, a tarefas de associações temporais, no intuito de verificar se o tempo subjetivo (de músicos e não músicos) é afetado por: (a) emoções específicas percebidas durante uma escuta musical (variável emocional), (b) manipulações de modo e andamento musical (variável estrutural) e (c) pela interação entre estas duas variáveis. 


\subsubsection{INTRODUÇÃO}

O Experimento II do presente trabalho sugeriu que houve influência de uma emoção específica (Tristeza) desencadeada durante tarefas de escuta musical na percepção temporal de músicos, reforçando a idéia de Angrilli (1997) a respeito da ocorrência de subestimações temporais em relação a eventos desencadeadores de arousal e valência afetiva negativos ${ }^{4}$. Porém, diferentemente dos dados obtidos por este autor, nenhuma superestimação temporal foi encontrada: para o grupo Músicos, apenas um trecho musical associado à emoção Serenidade foi também subestimado; para o grupo Não Músicos, pelo menos um trecho associado a cada categoria emocional analisada (Alegria, Tristeza, Serenidade e Medo/Raiva) foi subestimado em relação a suas durações reais (20 segundos). Para todos os outros trechos musicais empregados, não foram encontradas diferenças significativas que permitissem inferir alguma subestimação ou superestimação temporal, para ambos os grupos.

Entretanto, os dados obtidos no experimento II do presente estudo ainda não esclareceram quais foram os aspectos emocionais desencadeados durante a escuta musical que interferiram na percepção temporal de músicos e não músicos. Estes dados sugerem algumas hipóteses acerca desta questão: a primeira está centrada na idéia de que os trechos musicais associados às outras categorias emocionais (Alegria, Serenidade e Medo/Raiva) não foram capazes de envolver os sujeitos em atividades emocionais intensas a ponto de alterar a percepção subjetiva do tempo para ambos os grupos; dessa forma, é possível que outros tipos de estímulos (musicais ou visuais) possam ser mais apropriados para serem utilizados em estudos dessa natureza; a segunda está centrada na idéia da existência de alguma característica estrutural da música (como modo, andamento, contorno melódico, timbre, etc.)

\footnotetext{
4 A Tristeza é considerada uma emoção desencadeadora de arousal e valência afetiva negativos (RUSSEL, 1980).
} 
que poderia atuar de forma decisiva na percepção subjetiva de tempo, independentemente da emoção desencadeada durante a escuta musical, em ambos os grupos; a terceira está centrada na idéia de que o tempo subjetivo (de músicos e não músicos) poderia ser alterado pela interação entre estes dois fatores (emoções percebidas durante a escuta musical versus características estruturais da música).

No intuito de clarificar respostas para estas hipóteses, este experimento teve como objetivo submeter os trechos musicais modais com variação de andamento, utilizados no Experimento III, a tarefas relacionadas ao processamento temporal, no intuito de verificar se o tempo subjetivo (de músicos e não músicos) é afetado: (a) por algum componente emocional sentido pelos ouvintes durante a escuta musical, (b) por algum fator aditivo ou interativo entre as duas propriedades estruturais da música envolvidas (modo e andamento) e (c) pela interação dos componentes emocionais sentidos pelos ouvintes com os efeitos aditivos ou interativos do modo e do andamento, durante a escuta musical.

\subsubsection{MÉTODO}

Participantes: a amostra de sujeitos foi dividida em dois grupos: 21 estudantes de um curso de graduação em Música, que tinham pelo menos seis anos de experiência de estudo sistematizado de algum instrumento musical oferecido pelo curso: piano, violão, violino, viola, violoncelo, contrabaixo, flauta transversal, clarineta, trombone ou saxofone (classificados neste estudo como músicos) e 21 participantes que não tinham nenhuma experiência em estudo de música (classificados neste estudo como não músicos). Todos os participantes tinham entre 17 e 33 anos de idade (média = 27,2 anos). Nenhum participante deste experimento teve participação nos Experimentos I, II e III. 
Equipamento e material: neste experimento, foram utilizados os mesmos equipamentos e materiais utilizados para as tarefas de comparação temporal, descritos para o Experimento II, exceto os trechos musicais: neste experimento, foram utilizados os 63 trechos musicais modais utilizados no Experimento III.

Procedimento: o procedimento foi o mesmo utilizado no Experimento II.

A divisão dos 63 trechos musicais em três lotes experimentais foi feita da mesma maneira que aquela feita no Experimento III.

Este experimento durava, em média, 39 minutos.

Análise de dados: foi feita uma análise de dados similar àquela realizada no Experimento II do presente trabalho.

\subsubsection{RESULTADOS}

O teste de Kolmogorov-Smirnov (teste Z) foi aplicado para verificar a normalidade dos dados. Este teste apontou normalidade dos dados para todas as músicas apresentadas para o grupo Músicos. Para o grupo Não Músicos, a única música cujos dados rejeitaram normalidade foi a música número $16(\mathrm{Z}=1,763 ; \mathrm{p}=0,004)$. Para todas as outras músicas, o teste $\mathrm{Z}$ confirmou a normalidade dos dados.

O teste t-Student foi utilizado para comparar a média das associações temporais dos participantes músicos e não músicos com as durações reais de cada trecho musical, 20 segundos. A Tabela 6 indica a média numérica e os desvios-padrão das durações 
temporais fornecidas pelos participantes músicos e não músicos através das tarefas de associação temporal. Foram consideradas diferenças estatísticas significativas os níveis de significância menores que 0,05 . As diferenças estão assinaladas com um asterisco.

Tabela 6. Médias e desvios-padrão das durações temporais feitas por músicos e não músicos através da tarefa de associação temporal em trechos musicais com variações de modo e andamento. Os trechos musicais modais estão organizados dentro de cada andamento, conforme a hierarquia modal sugerida por Wisnik (2004).

\begin{tabular}{|c|c|c|c|c|c|}
\hline Andamentos & Trechos Musicais & \multicolumn{2}{|c|}{ Músicos } & \multicolumn{2}{c|}{ Não Músicos } \\
\hline & & Médias (seg.) & Desvios-padrão & Médias (seg.) & Desvios-padrão \\
\hline & Lídio 72 & 18,952 & 3,008 & 19,238 & 2,233 \\
\hline & Jônico 72 & 19,143 & 2,33 & 20 & 2,449 \\
\hline & Mixolídio 72 & 19,809 & 2,676 & 18,381 * & 2,872 \\
\hline Largo & Dórico 72 & 19,429 & 3,042 & $17,619 *$ & 1,857 \\
\hline & Eólio 72 & 20,095 & 3,129 & $18,667 *$ & 2,129 \\
\hline & Frígio 72 & $18,095 *$ & 1,841 & 19,619 & 1,962 \\
\hline & Lócrio 72 & 19,238 & 2,718 & 19,429 & 1,912 \\
\hline & Lídio 108 & 19,714 & 2,39 & $18,381 *$ & 2,418 \\
\hline & Jônico 108 & 19,429 & 3,042 & 19,714 & 2,305 \\
\hline Moderato & Mixolídio 108 & 19,809 & 3,156 & 20,095 & 2,142 \\
\hline & Dórico 108 & 19,714 & 3,18 & 20,381 & 2,061 \\
\hline & Eólio 108 & 19,429 & 2,619 & 20,286 & 2,305 \\
\hline & Frígio 108 & 19,809 & 3,092 & 20 & 2,228 \\
\hline & Lócrio 108 & 20 & 2,757 & $17,619 *$ & 2,418 \\
\hline & Lídio 184 & 19,429 & 2,838 & 19,524 & 2,75 \\
\hline & Jônico 184 & 20,381 & 2,941 & 21,048 ** & 2,156 \\
\hline & Mixolídio 184 & 21,048 & 2,73 & 19,809 & 2,182 \\
\hline & Dórico 184 & 19,905 & 2,488 & 19,333 & 2,781 \\
\hline & Eólio 184 & 19,524 & 2,822 & 19,333 & 1,826 \\
\hline & Frígio 184 & 19,809 & 2,822 & 21,524 ** & 2,96 \\
\hline & Lócrio 184 & 19,809 & 2,6 & 20,191 & 2,522 \\
\hline
\end{tabular}

* Indica subestimação temporal.

**Indica superestimação temporal.

Os dados presentes na Tabela 6 mostram que houve mais diferenças estatísticas significativas nas estimações temporais do grupo Não Músicos em relação ao grupo Músicos. Estes resultados sugerem a idéia de que os músicos podem ter uma acuidade maior para tarefas de associações temporais do que os não músicos, ou seja, a aquisição da habilidade musical pode estar relacionada com a acurácia em tarefas relacionadas com a percepção subjetiva do tempo. 
Com relação à subestimação temporal, para o grupo Não Músicos, foram subestimados os trechos musicais DOR $72(\mathrm{t}(20)=-5,876 ; \mathrm{p}=0,001)$, MIX $72(\mathrm{t}(20)=$ 3,068; $\mathrm{p}=0,006)$, EOL $72(\mathrm{t}(20)=-2,87 ; \mathrm{p}=0,09)$ e LOC $108(\mathrm{t}(20)=-4,512 ; \mathrm{p}=0,001)$. Para o grupo Músicos, o trecho musical FRI $72(\mathrm{t}(20)=-4,74 ; \mathrm{p}=0,0001)$ foi subestimado.

Com relação à superestimação temporal, para o grupo Não Músicos, foram superestimados os trechos musicais JON $184(\mathrm{t}(20)=2,227 ; \mathrm{p}=0,038)$ e FRI 184 (t $(20)=$ $2,359 ; p=0,029)$. Não houve superestimação temporal para as estimações temporais do grupo Músicos.

Todos os outros trechos musicais não foram nem subestimados e nem superestimados em relação às suas durações reais, para ambos os grupos.

Assim, os dados da Tabela 6 sugerem que, para ambos os grupos, foram subestimados, em relação à sua duração real, estímulos com andamento largo (neste andamento, os modos Dórico, Mixolídio e Eólio foram subestimados pelo grupo Não Músicos e o modo Frígio foi subestimado pelo grupo Músicos), sugerindo que a diminuição do andamento pode afetar a estimação temporal.

Além disso, o modo Lócrio, em andamento moderato também foi subestimado pelo grupo Não Músicos.

Em contrapartida, todas as superestimações temporais encontradas no grupo Não Músicos foram referentes aos trechos musicais em andamento presto (modos Jônio e Frígio), sugerindo que a aceleração do andamento musical pode estar relacionada à superestimação temporal para este grupo de sujeitos.

Com relação à comparação entre as associações temporais dos músicos e não músicos, poucas diferenças foram encontradas: apenas para os trechos musicais DOR 72 $[F(1,40)=5,412 ; p=0,025]$, FRI $72[F(1,40)=6,737 ; p=0,013]$ e LOC $108[F(1,40)=$ 
7,551; $\mathrm{p}=0,009]$ houve diferenças estatísticas significativas. Assim, os não músicos associaram os trechos DOR 72 e LOC 108 como sendo mais curtos em relação às associações dos músicos. Em contrapartida, os não músicos associaram o trecho FRI 72 como sendo mais longo em relação às associações dos músicos. Não houve diferenças estatísticas significativas entre as associações temporais de músicos e não músicos para os outros trechos musicais apresentados.

A Tabela 7 ilustra uma comparação entre as associações temporais e os julgamentos emocionais realizados no Experimento III de músicos e não músicos em relação aos trechos musicais apresentados.

Tabela 7. Comparação entre os julgamentos emocionais realizados no Experimento III e as associações temporais de músicos e não músicos em relação aos trechos musicais apresentados. Os julgamentos emocionais se encontram no primeiro nível da tabela e estão expressos através do nome das emoções analisadas. As associações temporais se encontram no segundo nível da tabela e estão categorizadas conforme a distância em relação às durações reais dos trechos musicais (20 segundos). A ordem de apresentação dos modos seguiu a hierarquia modal sugerida por (Wisnik, 2004).

\begin{tabular}{|c|c|c|c|c|c|c|}
\hline \multicolumn{7}{|c|}{ Associações emocionais } \\
\hline & \multicolumn{3}{|c|}{ Músicos } & \multicolumn{3}{|c|}{ Não Músicos } \\
\hline Modo & \multicolumn{3}{|c|}{ Andamento } & \multicolumn{3}{|c|}{ Andamento } \\
\hline & 72 & 108 & 184 & 72 & 108 & 184 \\
\hline Lídio & * & Serenidade & Alegria & Tristeza & Serenidade & Alegria \\
\hline Jônio & Serenidade & Alegria & Alegria & Serenidade & Alegria & Alegria \\
\hline Mixolídio & Serenidade & Serenidade & Alegria & Tristeza & Serenidade & Alegria \\
\hline Dórico & Tristeza & Serenidade & $*$ & Tristeza & Serenidade & Alegria \\
\hline Eólio & Tristeza & * & Alegria & $*$ & * & Alegria \\
\hline Frígio & Tristeza & * & $*$ & Tristeza & * & $*$ \\
\hline Lócrio & Medo / Raiva & Medo / Raiva & Medo / Raiva & Tristeza & Medo / Raiva & Medo / Raiva \\
\hline \multicolumn{7}{|c|}{ Associações temporais } \\
\hline & \multicolumn{3}{|c|}{ Músicos } & \multicolumn{3}{|c|}{ Não Músicos } \\
\hline Modo & \multicolumn{3}{|c|}{ Andamento } & \multicolumn{3}{|c|}{ Andamento } \\
\hline & 72 & 108 & 184 & 72 & 108 & 184 \\
\hline Lídio & próxima & próxima & próxima & próxima & subestimação & próxima \\
\hline Jônio & próxima & próxima & próxima & próxima & próxima & superestimação \\
\hline Mixolídio & próxima & próxima & próxima & subestimação & próxima & próxima \\
\hline Dórico & próxima & próxima & próxima & subestimação & próxima & próxima \\
\hline Eólio & próxima & próxima & próxima & subestimação & próxima & próxima \\
\hline Frígio & subestimação & próxima & próxima & próxima & próxima & superestimação \\
\hline Lócrio & próxima & próxima & próxima & próxima & subestimação & próxima \\
\hline
\end{tabular}

* Indica que o trecho musical não foi associado a uma categoria emocional específica. 
Os dados da Tabela 7 nos revelam que não há uma relação direta entre as subestimações e as superestimações temporais e os julgamentos emocionais de Músicos e Não músicos.

Considerando o grupo Não Músicos, os trechos musicais que foram subestimados temporalmente (DOR 72, MIX 72, EOL 72, LID 108 e LOC 108) são pertencentes a diferentes categorias emocionais. Os trechos DOR 72 e MIX 72 foram associados à Tristeza, o trecho EOL 72 não foi associado a uma emoção específica, o estímulo LID 108 foi associado à emoção Serenidade e o trecho LOC 108 foi associado à emoção Medo ou Raiva. Assim, pode-se inferir que a subestimação temporal, ocorrida no grupo Não Músicos, não pode ter sido estabelecida através do desencadeamento de uma emoção específica: é possível que cada modo, aliado a cada andamento, adquira características psicofísicas distintas e que podem estar associadas à subestimação temporal. Da mesma maneira, os trechos musicais que foram superestimados temporalmente (JON 184 e FRI 184) também são pertencentes a categorias emocionais distintas. O trecho JON 184 foi associado à emoção Alegria e o trecho FRI 184 não foi associado a uma emoção específica. Assim, pode-se inferir que a superestimação temporal, ocorrida no Grupo Não Músicos, também não pode ter sido estabelecida através do desencadeamento de uma emoção específica. No entanto, os dados revelam pistas de que o andamento musical pode ser um dos fatores responsáveis pela superestimação temporal: de fato, os dois trechos musicais que foram superestimados, para o grupo Não Músicos, estavam no andamento presto.

Considerando o grupo Músicos, o trecho musical FRI 72 foi subestimado temporalmente. Este trecho pertence à categoria emocional Tristeza. Este dado reforça os dados obtidos no Experimento II, onde os trechos musicais representativos da emoção Tristeza foram subestimados temporalmente. No entanto, outros trechos musicais modais desencadeadores de Tristeza, neste experimento, não foram subestimados temporalmente. 
Assim, pode-se inferir que o isolamento das variáveis modo e andamento pode ter diminuído a capacidade do desencadeamento da emoção Tristeza nos trechos musicais modais apresentados neste experimento, com exceção do modo Frígio, onde estas variáveis foram o suficiente para desencadear esta emoção. Assim, se faz necessário um estudo envolvendo outras variáveis musicais (como timbre, contorno melódico, dinâmicas, etc.) que potencializam o desencadeamento de emoções específicas nos ouvintes. Ademais, com referência ao grupo Músicos, os dados deste experimento reforçaram a idéia de que a Tristeza esteja relacionada à subestimação temporal. Também se faz necessário um estudo mais aprofundado sobre o desencadeamento de emoções em músicos e não músicos, que leve em conta outras emoções que reflitam diferentes proporções de arousal e valência afetiva.

\subsubsection{DISCUSSÃO}

O presente experimento procurou verificar se o tempo subjetivo (de músicos e não músicos) é afetado por algum componente emocional sentido pelos ouvintes durante a escuta musical, por algum fator aditivo ou interativo entre as duas propriedades psicofísicas das músicas analisadas no estudo (modo e andamento) ou ainda, por uma interação entre estes dois fatores (emocional x estrutural).

Os dados obtidos apontam que a maioria dos trechos musicais foi associada a durações próximas em relação a suas durações reais (20 segundos) para ambos os grupos. Além disso, os resultados mostram a inexistência de nenhuma superestimação temporal para o grupo Músicos e duas superestimações temporais para o grupo Não Músicos, nas quais ambas foram encontradas em trechos musicais apresentados no andamento presto, sendo uma para o modo Jônio e outra para modo Frígio. Em ambos os trechos musicais, a emoção 
desencadeada no experimento anterior foi Alegria. Com relação às subestimações temporais, os resultados obtidos neste experimento mostram apenas uma subestimação temporal para o grupo Músicos (encontrada no modo Frígio, em andamento adágio), cinco subestimações temporais para o grupo Não Músicos (três delas encontradas no andamento adágio, correspondentes aos modos Mixolídio, Dórico e Eólio, e duas delas encontradas no andamento moderato, correspondentes aos modos Lídio e Lócrio). Com relação às emoções desencadeadas aos mesmos trechos musicais no experimento anterior, os resultados deste estudo mostram duas subestimações associadas à emoção Tristeza, uma subestimação associada à emoção Serenidade, uma subestimação associada à categoria emocional Medo/Raiva e uma subestimação temporal associada a um trecho musical que não desencadeou nenhuma emoção específica nos ouvintes.

Alguns dos resultados obtidos neste experimento convergiram para os resultados obtidos por Angrilli et al. (1997), nos quais foram encontradas interações significantes entre o arousal e a valência afetiva sobre a percepção temporal: em contextos envolvendo altos índices de arousal, a duração de figuras que sugeriam valências afetivas negativas foi superestimada em relação à duração de figuras que sugeriam valência afetiva neutra ou positiva em sujeitos não treinados em música; em contextos envolvendo baixos índices de arousal, figuras que sugeriam valência afetiva negativa foram subestimadas e figuras que sugeriam valência afetiva positiva foram superestimadas. No entanto, diferentemente dos dados obtidos neste experimento, os dados de Angrilli et al. (1997) foram obtidos com o emprego de estímulos visuais de curta duração ( 2 segundos) e em participantes não treinados em música. Além disso, no estudo de Angrilli et al. (1997), não foi encontrada nenhuma influência das emoções sobre a percepção temporal para longas durações.

Considerando os dados deste experimento, assim como em Angrilli et al. (1997), a única subestimação temporal encontrada no grupo Músicos também esteve 
associada a uma condição de arousal e de valência afetiva negativos. Para o grupo Não Músicos, das cinco subestimações temporais encontradas, duas delas também estiveram associadas a índices de arousal e de valência negativos; no entanto, duas subestimações temporais foram associadas a índices de arousal negativo e valência afetiva positiva, enquanto, no estudo de Angrilli et al. (1997), estímulos visuais sobre estas condições foram superestimados em relação a suas durações reais. Além disso, no presente experimento, uma subestimação temporal esteve associada a índices de arousal positivo e valência afetiva negativa pelos não músicos, enquanto, no estudo de Angrilli et al. (1997), estímulos visuais sobre estas condições foram superestimados em relação a suas durações reais.

Com relação às superestimações temporais, os dados encontrados neste experimento, para o grupo Não Músicos, convergem para os resultados apresentados por Angrilli et al. (1997): eventos que desencadearam arousal e valência afetiva positiva foram superestimados em relação às suas durações reais, por estes ouvintes.

Assim, os resultados encontrados neste experimento sugerem uma associação da subestimação temporal com contextos envolvendo arousal e valência afetiva negativos e, no caso dos não músicos, estes dados sugerem uma superestimação temporal em contextos envolvendo arousal e valência afetiva positivos. Além disso, os não músicos subestimaram alguns trechos musicais que envolviam índices de arousal e valência afetiva divergentes (um negativo e outro positivo).

Os resultados do presente experimento alertam sobre a interferência de algumas variáveis que devem ser consideradas para se estabelecer de forma precisa o processamento temporal dos participantes envolvidos em estudos futuros. Tais variáveis envolvem o tipo de sujeito analisado (músicos e não músicos), a modalidade do estímulo empregado (musical ou visual) e a duração envolvida nos eventos (curta, da ordem de milissegundos ou longa, a partir de 2 segundos). Droit-Volet, Tourret e Wearden (2004), em 
um estudo que comparou a influência de variáveis como tipo de evento (sonoros ou visuais) e tipo de sujeitos (crianças e adultos) sobre a influência das emoções na percepção temporal humana, encontraram que, independente da faixa etária considerada, houve superestimação de estímulos sonoros em relação aos estímulos visuais. No entanto, estes estímulos sonoros não correspondiam à música, mas sim a efeitos sonoros. Estas diferenças foram encontradas apenas por meio do emprego de tarefas de bissecção temporal nos participantes. Zakay (1990) já havia alertado sobre o fato de que o tipo de tarefa temporal empregada também poderia ser uma variável que influenciaria os resultados sobre a estimação temporal de eventos de diferentes naturezas. Portanto, é possível que a realização de mais estudos interativos, envolvendo diferentes variáveis, possa fornecer pistas mais esclarecedoras acerca da influência das emoções percebidas durante um evento no processamento temporal humano.

Diferentemente dos resultados obtidos no experimento II do presente trabalho, neste experimento, a subestimação temporal esteve associada ao grupo Não Músicos. Neste grupo, cinco subestimações foram encontradas, enquanto no grupo Músicos apenas uma subestimação foi encontrada. Portanto, o tipo de trecho musical empregado foi determinante no resultado das associações temporais de ambos os grupos: enquanto, no experimento II, as subestimações encontradas estiveram associadas a trechos musicais apresentados segundo uma abordagem analítica proposta por Berlyne (1974), os trechos musicais empregados neste experimento foram utilizados segundo uma abordagem sintética. Segundo Berlyne (1974), na abordagem analítica, a apreciação estética envolve obras de arte genuínas, enquanto em uma abordagem sintética a apreciação artística envolve a retirada de elementos de uma obra de arte para serem investigados (no presente caso, o modo e o andamento musical). Dessa forma, o tipo de abordagem estética (analítica ou sintética) também parece influenciar respostas sobre a influência das emoções musicais na percepção temporal humana, dependendo do tipo de sujeito envolvido. 
Este efeito do tipo de abordagem estética empregada com subestimações ou superestimações temporais parece estar relacionado com a expertise musical: se ouvintes músicos processam as emoções de forma mais "refinada" que ouvintes não músicos, então é possível que, dentro da abordagem sintética de Berlyne (1974), o processamento temporal dos músicos também seja mais "refinado" do que o processamento temporal dos não músicos. E isto pôde ser comprovado nos questionários experimentais aplicados após o término do experimento: alguns músicos relataram que reconheceram as diferenças sonoras entre alguns modos musicais; além disso, a maioria deles também relatou que os trechos musicais tinham uma estrutura rítmica fácil de ser repetida, e, portanto, ficava fácil demarcar cada trecho musical ritmicamente (os trechos musicais eram todos em compassos simples, com o ritmo exposto pela harmonia de forma bem definida, vide Apêndices 3 e 4 do presente trabalho). Desta forma, é possível que a facilidade para marcar a pulsação dos trechos musicais possa ter sido a responsável pelas respostas temporais dos músicos terem sido feitas de forma bastante precisa, a maioria delas sendo associadas às durações reais dos trechos musicais (20 segundos). Considerando os não músicos, pelo fato de não terem sido treinados ritmicamente por meio de estudo sistematizado, eles podem não ter sido capazes de definir, com precisão, a pulsação dos trechos musicais e, por conseqüência disso, a maioria das respostas temporais não foi associada às durações reais dos trechos musicais (20 segundos), ocasionando, assim, as subestimações ou superestimações temporais. Em outras palavras, como a expertise musical proporciona aos músicos a obtenção de um senso rítmico mais apurado do que aos não músicos (GALVÃO, 2006), é possível que, por causa dela, os músicos consigam processar o tempo de duração do evento de acordo com o número de pulsações que eles acumularem durante a tarefa de escuta musical. Uma possível prova disso é que no experimento II do presente trabalho, as subestimações dos músicos foram encontradas em 
trechos musicais que não possuíam uma pulsação musical tão definida como nos trechos musicais empregados neste experimento (vide Anexo 4 do presente estudo).

Outra hipótese a ser considerada a respeito da não-obtenção de subestimações ou superestimações temporais dos músicos pode ser pensada a respeito do número de eventos ocorridos simultaneamente nos trechos musicais. Assim, os trechos musicais empregados no experimento II possuíam um número maior de elementos que envolviam diferentes estruturas musicais (modo, andamento, dinâmica, contornos melódicos, entre outros). Em outras palavras, não havia um controle experimental sobre estas variáveis estruturais (diferentemente deste experimento, no qual as variáveis de modo e andamento foram sistematicamente controladas). Dessa forma, é possível que os músicos participantes deste experimento possam ter percebido (conscientemente ou não) este controle de variáveis. Por exemplo: 63 trechos musicais foram utilizados neste experimento; estes trechos foram divididos em três lotes experimentais; cada lote experimental apresentou, para cada participante, três composições musicais, estando em sete modos e três andamentos; portanto, cada participante ouvia a mesma música sete vezes, com alguma alteração (no modo e/ou no andamento); assim, pelo fato de músicos terem uma escuta musical "mais refinada" do que a escuta musical dos não músicos (BIGAND et al., 2005), esta repetição de um mesmo evento musical com uma ou outra alteração (no modo e/ou no andamento) pode ter ocasionado uma aprendizagem por parte dos músicos, a respeito da duração dos eventos. Esta idéia pôde ter sido comprovada em vários dos relatos obtidos nos questionários experimentais aplicados após o experimento, que estavam centrados na idéia de que "se a música é a mesma e o que muda é, no caso, o modo ou o andamento, então todas elas devem ter a mesma duração”. Portanto, se considerarmos os dados do Experimento II do presente estudo, nos quais os músicos pareceram envolver-se emocionalmente com os trechos musicais associados à Tristeza (a ponto de perderem a noção do tempo durante a escuta), este fator comprovado pela análise dos questionários aplicados 
após o experimento (a respeito dos trechos musicais serem bastante parecidos) pode ter interferido no envolvimento emocional dos músicos durante a escuta musical e, por conseqüência disso, as subestimações temporais encontradas no experimento II não foram encontradas neste experimento.

Portanto, os resultados deste experimento sugerem que o tipo de estímulo musical empregado em estudos que objetivam mensurar a percepção temporal de músicos deve ser cuidadosamente elaborado, no intuito de não delimitar uma pulsação rítmica definida, que facilitaria um melhor desempenho destes sujeitos em tarefas de associações temporais.

Com relação aos modelos de percepção temporal encontrados na literatura e com os resultados previamente discutidos no experimento II do presente trabalho, o modelo do relógio interno proposto por Gibbon, Church e Meck (1984) parece fornecer uma explicação mais precisa sobre os processos psicológicos envolvidos na percepção temporal dos músicos e dos não músicos deste experimento. Este modelo sugere a existência de um relógio interno, composto por um marcapasso e um interruptor, que avalia o tempo conforme os pulsos emitidos pelo primeiro são acionados ou paralisados pelo segundo; a estimação temporal, então, está baseada em um número de pulsos acumulados: quanto maior o número de pulsos, maior o tempo a ser julgado. Assim, uma hipótese para explicar os dados obtidos neste estudo é a de que as subestimações ou superestimações temporais encontradas estiveram relacionadas com o andamento dos trechos musicais. Este andamento, por sua vez, estaria relacionado com o nível de arousal desencadeado durante a escuta musical. Uma prova disso é que, no Experimento III do presente trabalho, o andamento musical modulou o arousal desencadeado pelos trechos musicais: quanto mais rápido o andamento do trecho musical, maiores os níveis de arousal desencadeados e vice-versa. Os dados deste experimento mostraram, para os não músicos, subestimações temporais encontradas principalmente para 
trechos apresentados em andamentos lentos (desencadeadores de arousal negativo) e superestimações temporais encontradas apenas para alguns trechos musicais apresentados em andamentos rápidos (desencadeadores de arousal positivo). Por outro lado, os dados encontrados no experimento III do presente estudo apresentam o modo musical como sendo o modulador da valência afetiva desencadeada pelos trechos musicais: uns apresentados em modos maiores obtiveram índices positivos de valência afetiva e outros apresentados em modos menores obtiveram índices negativos de valência afetiva. Neste experimento, não ocorreu nenhuma relação da hierarquia modal sugerida por Wisnik (2004) com subestimações ou superestimações temporais. Em outras palavras: neste experimento, não houve um efeito do modo nas subestimações ou superestimações temporais, mas sim, do andamento. E, como o andamento pode ser interpretado como o modulador do arousal desencadeado durante a escuta a partir dos dados encontrados no experimento III, é possível inferir que alguns trechos musicais que desencadearam níveis de arousal positivo durante a escuta levaram os sujeitos não músicos a superestimarem o tempo; da mesma forma, alguns trechos musicais que desencadearam níveis de arousal negativo durante a escuta levaram os sujeitos não músicos a subestimarem o tempo.

Considerando o modelo do relógio interno (GIBBON; $\mathrm{CHURCH}$; $\mathrm{MECK}$, 1984), é possível que, durante a escuta dos não músicos, o andamento do trecho musical tenha determinado a velocidade do marcapasso acionado pelo emissor de pulsos. Neste sentido, um andamento lento sugeriria pulsações lentas e, portanto, um menor número de pulsos acumulados e, conseqüentemente, ocasionaria uma subestimação temporal ao final do evento. Ao contrário, um andamento musical rápido sugeriria pulsações rápidas e, portanto, um maior número de pulsos acumulados e, conseqüentemente, ocorreria uma superestimação temporal ao final do evento. Em outras palavras, o andamento musical pode ter ocasionado um efeito ilusório na mente dos não músicos. Por outro lado, os músicos, sendo treinados ritmicamente 
em função da expertise musical adquirida, podem não ter sofrido este efeito ilusório e, em conseqüência disso, os trechos musicais apresentados foram associados às suas próprias durações reais (20 segundos).

Finalmente, a conclusão deste estudo é de que a percepção temporal dos não músicos foi alterada em função do arousal desencadeado durante algumas escutas musicais: alguns trechos musicais desencadeadores de níveis de arousal positivos foram superestimados em relação às suas durações reais e alguns trechos musicais desencadeadores de níveis de arousal negativos foram subestimados em relação às suas durações reais. Estes dados também foram encontrados por Angrilli et al. (1997), em relação a estímulos visuais, de curta duração, para sujeitos não treinados em música. No entanto, o mesmo não ocorreu com os músicos participantes do presente estudo, em função da expertise musical: pode ser que, por processarem a informação musical de forma mais "refinada" que os não músicos (BIGAND et al., 2005), o treinamento musical adquirido por estes ouvintes pode ter sido decisivo para que os níveis de arousal encontrados durante a escuta musical não tenham influenciado a percepção temporal, uma vez que os níveis de arousal dependeram do andamento musical empregado (vide Experimento III do presente trabalho). Assim, os anos de treinamento musical obtidos pelos músicos podem ter facilitado o entendimento de que os trechos musicais tinham a mesma duração (o que mudava era o modo e o andamento musical, dimensões que não estão relacionadas com o tamanho do evento). Portanto, no caso dos músicos, as subestimações e superestimações temporais não dependeram do andamento musical e, conseqüentemente, a percepção temporal destes sujeitos não foi influenciada pelo arousal desencadeado pelos trechos musicais durante as escutas. 
4. CONCLUSÃO 
Este estudo objetivou verificar o papel das emoções musicais percebidas durante a escuta musical na percepção temporal de músicos e não músicos. Quatro experimentos foram realizados no intuito de analisar esta questão.

O Experimento I procurou verificar respostas emocionais de músicos e não músicos a trechos musicais (do repertório erudito ocidental) pertencentes aos períodos Barroco, Clássico, Romântico e Contemporâneo. De maneira geral, a maioria dos trechos musicais do repertório erudito ocidental desencadeou uma única emoção específica em ouvintes ocidentais (de uma mesma cultura), reforçando os dados já obtidos em estudos existentes na literatura acerca da questão (HEVNER, 1935, 1936; ROBAZZA; MACALUSO; D’URSO, 1994; JUSLIN; SLOBODA, 2001; JUSLIN; LAUKKA, 2004; BIGAND et al., 2005). No entanto, alguns trechos musicais não desencadearam uma única emoção específica em ambos os grupos. Esta não-associação pode depender de alguns fatores: (1) o tipo de teste empregado para mensurar as emoções musicais (os relatos obtidos por meio dos questionários aplicados após o experimento apresentaram dúvidas de alguns participantes para associar certos trechos musicais a uma única emoção, alegando que alguns trechos musicais poderiam ser associados a outros léxicos não empregados no estudo, como Melancolia, Paixão, Amor, etc.); (2) o fato de um mesmo trecho musical possuir elementos estruturais relacionados a mais de uma categoria emocional ao mesmo tempo (Alegria e Tristeza), conforme revisão feita por Juslin e Laukka (2003), confundindo assim, as associações emocionais dos ouvintes; (3) a presença de mudanças bruscas de ordem estrutural no decorrer do evento musical; tais mudanças dividiram alguns trechos musicais em um ou mais "períodos emocionais", ocasionando associações emocionais ambíguas pelos ouvintes. Portanto, os resultados obtidos com a realização deste experimento nos permitiram concluir que, assim como no estudo realizado por Bigand et al. (2005), as emoções musicais parecem depender mais da cognição dos elementos da estrutura musical de uma obra do que da história pessoal de cada um. Além 
disso, apesar de o teste de escolha forçada ter limitado o número de categorias emocionais a serem escolhidas pelos ouvintes, este teste foi eficiente para categorizar emocionalmente alguns trechos musicais apropriados para serem submetidos a tarefas de associação temporal, que foi desenvolvida no experimento subseqüente.

O Experimento II procurou agrupar os trechos musicais empregados no experimento anterior em categorias emocionais (Alegria, Tristeza, Serenidade, Medo/Raiva) e, a partir dos resultados obtidos, submetê-los a tarefas relacionadas ao processamento temporal, no intuito de verificar se a percepção temporal (de músicos e não músicos) foi afetada por algum componente emocional sentido pelos ouvintes durante a escuta musical. Os resultados obtidos apontam que houve influência das emoções desencadeadas durante uma escuta musical na percepção temporal dos músicos. Assim, apesar de o processamento emocional de músicos e não músicos ser semelhante (BIGAND et al., 2005), o processamento temporal dos trechos musicais apresentados foi diferente entre os grupos. Com relação ao grupo Músicos, as subestimações temporais em relação à duração real de cada estímulo (20 segundos) foram encontradas para os três trechos musicais associados à emoção Tristeza e para apenas um trecho musical associado à emoção Serenidade. Com relação ao grupo Não Músicos, pelo menos um trecho associado a cada categoria emocional analisada (Alegria, Tristeza, Serenidade e Medo/Raiva) foi subestimado em relação à sua duração real. Não houve nenhuma superestimação temporal sobre nenhum trecho musical para ambos os grupos. Os resultados obtidos neste experimento convergem para os resultados obtidos por Angrilli et al. (1997), encontrados para estímulos visuais (figuras que sugerem combinações de níveis de arousal e valência afetiva), em sujeitos não músicos, envolvendo apreciações estéticas de curta duração (na ordem dos milissegundos): em contextos envolvendo baixos índices de arousal, eventos que sugerem valência afetiva negativa foram subestimados em relação à sua duração real. Além disso, os resultados obtidos no Experimento II do presente 
estudo alertam sobre algumas variáveis estéticas que podem interferir no estudo sobre a influência das emoções percebidas durante um evento sobre a percepção temporal humana, como familiaridade do sujeito ao evento apreciado, as durações investigadas (curtas ou longas) e o tipo de metodologia aplicada (bissecção, comparação, reprodução temporais, etc.). Dois modelos de percepção temporal encontrados na literatura parecem dar conta de explicar os resultados obtidos no presente estudo: (1) O modelo atencional proposto por Hicks et al. (1976) sugere a hipótese de que as subestimações temporais referentes aos trechos musicais desencadeadores de Tristeza nos músicos tenham ocorrido devido ao forte envolvimento emocional deles com estes trechos musicais, a ponto de tê-los distraído em relação à tarefa temporal; dessa forma, os sujeitos parecem ter levado em conta apenas os momentos da escuta em que estavam atentos à tarefa temporal, descartando, assim, os momentos da escuta em que perderam a noção da passagem do tempo; esta perda momentânea da passagem do tempo favoreceria a ocorrência das subestimações temporais sobre estes trechos musicais dos músicos. (2) O modelo do relógio interno, proposto por Gibbon, Church e Meck (1984) sugere que o forte envolvimento emocional dos músicos com os trechos musicais desencadeadores de Tristeza pode ter acionado o interruptor de pulsos do suposto marcapasso sugerido pelo modelo; assim, um menor número de pulsos pode ter sido acumulado no momento final dos trechos musicais em relação ao número de pulsos real do estímulo e, por esta razão, o tempo pode ter sido subestimado. Apesar de os resultados obtidos neste estudo terem confirmado a influência de uma emoção específica (no caso, a Tristeza) na percepção temporal dos músicos, ainda não ficou esclarecido porque não houve influência de outras emoções sobre a percepção temporal humana. Algumas hipóteses merecem ser consideradas acerca da questão, como o fato de que os trechos musicais empregados parecem não ter sido capazes de envolver os sujeitos em atividades emocionais intensas a ponto de alterar a percepção subjetiva do tempo, ou a existência de alguma característica estrutural da música 
(como modo, andamento, contorno melódico, timbre, etc.) que poderia atuar de forma decisiva na percepção subjetiva de tempo, independentemente da emoção desencadeada durante a escuta musical ou, ainda, uma terceira hipótese centrada na idéia de que o tempo subjetivo (de músicos e não músicos) poderia ser alterado pela interação entre estes dois fatores (propriedades emocionais percebidas pelos ouvintes e propriedades estruturais da própria música). No intuito de clarificar estas hipóteses, mais dois experimentos foram realizados.

O Experimento III procurou verificar respostas emocionais de músicos e não músicos a trechos musicais construídos em diferentes modos (Lídio, Jônio, Mixolídio, Dórico, Eólio, Frígio e Lócrio) e diferentes andamentos musicais (adágio, moderato e presto). Os resultados deste estudo mostraram que pequenas alterações na estrutura escalar de dois modos musicais empregados modularam as respostas emocionais dos músicos e dos não músicos: tanto nos índices de arousal quanto nos índices de valência afetiva foram encontradas diferenças dentro de cada "nova categoria modal" inserida nos modos maiores (Lídio, Jônio e Mixolídio) e menores (Dórico, Eólio, Frígio e Lócrio). Estas diferenças foram encontradas devido à configuração intervalar (característica de cada modo musical) em relação a uma nota de referência. Esta constatação sugere que a bem estabelecida distinção “maior x menor” encontrada na literatura (HEVNER, 1935; DALLA BELLA et al., 2001a) é apenas um caso peculiar de um processo mais geral que rege as emoções musicais. Além disso, os resultados do Experimento III do presente estudo mostraram que o andamento modulou o arousal desencadeado pelos trechos musicais: quanto mais rápido o andamento do trecho musical, maiores os níveis de arousal desencadeados e vice-versa. Por essa via, quando o andamento dos trechos musicais empregados aumentou do lento para o moderado, todos os modos tenderam a ser associados à Serenidade; quando o andamento dos mesmos trechos musicais aumentou de moderado para o rápido, todos os modos tenderam a ser 
associados à Alegria. Da mesma forma, o modo musical modulou a valência afetiva desencadeada pelos trechos musicais, sugerindo uma organização emocional dos modos próxima à hierarquia modal sugerida por Wisnik (2004). Assim, os níveis de valência afetiva encontrados foram se tornando negativos, conforme os intervalos relacionados com a nota de referência característicos de cada modo iam ficando menores e diminutos, em ambos os grupos. Os resultados encontrados no Experimento III do presente trabalho sugerem o uso de outros léxicos emocionais a serem empregados em estudos sobre as emoções musicais em pesquisas futuras. Pelo fato de cada uma das categorias emocionais de base (Alegria, Tristeza, Serenidade e Medo/Raiva) estar localizada em pontos muito específicos do modelo circumplexo de Russel (1980) - cada categoria em um dos quatro quadrantes - o emprego de um número maior de léxicos musicais localizados em cada quadrante deste modelo postularia um grande número de emoções específicas a serem mensuradas durante a experiência de escuta musical. Assim, cada trecho musical apresentado desencadearia novos índices de arousal e de valência afetiva. Estes índices encontrados poderiam estar localizados em pontos em comum (ou muito próximos) de cada nova categoria emocional estabelecida a partir de cada subdivisão emocional de cada quadrante do modelo circumplexo. Isto determinaria, com mais precisão, a emoção específica relacionada a cada trecho musical apresentado aos ouvintes. Portanto, as chances de um mesmo trecho musical não estar associado a uma emoção específica diminuiriam, porque os ouvintes teriam uma gama maior de emoções a serem associadas. Apesar da crítica feita à metodologia referente ao tipo de mensuração das emoções musicais no presente experimento, os resultados mostraram que os trechos musicais com variações de modo e andamento empregados desencadearam emoções específicas nos ouvintes. Além disso, a manipulação destes dois parâmetros musicais sobre cada trecho musical desencadeou, nos sujeitos de ambos os grupos, diferentes níveis de arousal e valência afetiva. O quarto experimento foi realizado por meio da submissão dos trechos musicais 
modais com variação de andamento a tarefas de associação temporal, no intuito de verificar se a percepção temporal de músicos e não músicos é afetada por emoções específicas desencadeadas durante a escuta musical (componente emocional), por mudanças relacionadas a alterações de modo e do andamento musicais (componente estrutural) ou pela interação entre estes dois componentes.

Os resultados obtidos no último experimento do presente trabalho mostram que a maioria dos trechos musicais foi associada a durações próximas em relação à sua duração real (20 segundos) para ambos os grupos. No entanto, subestimações e superestimações temporais foram encontradas. Os resultados obtidos no Experimento IV pelos não músicos convergiram para os resultados obtidos por Angrilli et al. (1997) em participantes não treinados em música, em eventos visuais, envolvendo durações curtas (da ordem dos milissegundos): alguns eventos envolvendo baixos índices de arousal e valência afetiva negativa foram subestimados em relação às suas durações reais e eventos que desencadearam arousal e valência afetiva positivos foram superestimados em relação às suas durações reais, pelos não músicos.

Diferentemente dos resultados obtidos no Experimento II do presente trabalho, a respeito do processamento temporal, neste experimento, a subestimação temporal esteve associada ao grupo Não Músicos. Duas hipóteses podem ser inferidas a respeito da ausência de subestimações e superestimações temporais dos músicos: a primeira se refere à estrutura rítmica dos trechos musicais empregados, que podem ter facilitado uma demarcação temporal pelos músicos. Pelo fato de este grupo de sujeitos ter um treinamento rítmico adquirido ao longo de anos de estudo sistematizado em música, esta demarcação pode ter facilitado a associação temporal dos trechos musicais às suas próprias durações reais (20 segundos); a segunda hipótese refere-se ao fato de que, pelo fato de os trechos musicais empregados serem bastante parecidos, pode ser que os músicos tenham percebido que as músicas apresentadas 
eram as mesmas, porém, com alterações apenas no modo e no andamento, propriedades que não estão relacionadas com a duração dos trechos musicais. Portanto, os resultados deste experimento sugerem que o tipo de estímulo musical empregado em estudos que objetivam mensurar a percepção temporal de músicos deve ser cuidadosamente elaborado, no intuito de não delimitar uma pulsação rítmica definida, que facilitaria um melhor desempenho destes sujeitos em tarefas de associações temporais.

Os resultados do presente experimento também alertam sobre a interferência de algumas variáveis que devem ser consideradas para se estabelecer de forma precisa o processamento temporal dos participantes envolvidos em estudos futuros. Tais variáveis envolvem o tipo de sujeito analisado (músicos e não músicos), a modalidade do estímulo empregado (musical ou visual), a duração envolvida nos eventos (curtas, da ordem de milissegundos ou longas, a partir de 2 segundos) e o tipo de abordagem estética abordada (sintética ou analítica; ver em BERLYNE, 1974).

O modelo do relógio interno proposto por Gibbon, Church e Meck (1984) parece fornecer uma explicação mais precisa sobre os processos psicológicos envolvidos na percepção temporal dos músicos e dos não músicos deste experimento. No presente experimento, este modelo sugere a hipótese de que as subestimações ou superestimações temporais encontradas estiveram relacionadas com o andamento dos trechos musicais. Este andamento, por sua vez, estaria relacionado com o nível de arousal desencadeado durante a escuta musical. Assim, os trechos musicais em andamento rápido (que desencadearam níveis de arousal positivo durante a escuta) levaram os sujeitos não músicos a superestimarem o tempo; da mesma forma, trechos musicais em andamento lento (que desencadearam níveis de arousal negativo durante a escuta) levaram os sujeitos não músicos a subestimarem o tempo. Este modelo sugere a hipótese de que, durante a escuta dos não músicos, o andamento do trecho musical tenha determinado a velocidade do marcapasso acionado pelo emissor de 
pulsos. Neste sentido, um andamento lento sugeriria pulsações lentas e, portanto, um menor número de pulsos acumulados e, conseqüentemente, ocasionaria uma subestimação temporal ao final do evento. Ao contrário, um andamento musical rápido sugeriria pulsações rápidas e, portanto, um maior número de pulsos acumulado e, conseqüentemente, ocorreria uma superestimação temporal ao final do evento. Em outras palavras, o andamento musical pode ter ocasionado um efeito ilusório na mente dos não músicos. Por outro lado, os músicos, sendo treinados ritmicamente em função da expertise musical adquirida, podem não ter sofrido este efeito ilusório e, em conseqüência disso, os trechos musicais apresentados foram associados a durações próximas em relação à suas durações reais.

Após a realização destes quatro experimentos foi possível responder coerentemente à questão central do presente trabalho: fatores emocionais durante uma escuta musical afetam a percepção temporal de músicos e não músicos? A partir dos resultados obtidos no presente estudo, a resposta é positiva. No entanto, a forma como as emoções percebidas durante a escuta musical interferem na percepção temporal para cada grupo de sujeitos é diferente. Os dados obtidos no presente trabalho sugerem que as subestimações temporais dos músicos parecem estar enraizadas a um forte envolvimento emocional com trechos musicais desencadeadores da emoção Tristeza, a ponto de estes sujeitos desviarem a atenção à tarefa temporal durante a escuta. As subestimações e superestimações temporais dos não músicos, por sua vez, parecem estar enraizadas aos níveis de arousal desencadeados durante a escuta, proporcionados pela manipulação, principalmente, do andamento musical. Assim, as superestimações temporais parecem estar relacionadas a níveis de arousal positivos (andamentos musicais rápidos) e as subestimações temporais parecem estar relacionadas a níveis de arousal negativos (andamentos lentos).

Os resultados obtidos com a realização destes experimentos sugerem ainda que, para a continuação destes estudos, seja feito um controle de variáveis sistemático, 
levando-se em conta, principalmente, o tipo de sujeito envolvido (músicos ou não músicos), o tipo de evento apreciado (visual ou musical), a abordagem estética utilizada (analítica ou sintética) e o tipo de metodologia a ser aplicada, tanto para a mensuração das emoções, (como os testes de escolha forçada, taxas emocionais ou as descrições livres, por exemplo), como para a mensuração do tempo subjetivo (como tarefas de associação, comparação ou reprodução temporais, etc.). Neste sentido, um outro estudo sobre a influência das emoções percebidas durante uma escuta musical sobre a percepção temporal de músicos e não músicos já está sendo elaborado pelo autor do presente trabalho, no intuito de dar continuidade a esta pesquisa. Este estudo envolverá medidas temporais sobre trechos musicais (associados a emoções específicas) por meio de diferentes métodos de mensuração temporal: associação, bi-secção, comparação, entre outros. O objetivo deste estudo é verificar se o tipo de metodologia aplicada interfere na influência das emoções percebidas durante uma escuta musical sobre a percepção temporal de músicos e não músicos. A partir de uma análise sobre os estudos encontrados na literatura, espera-se que o tipo de metodologia aplicada não interfira no processamento temporal de ambos os grupos de sujeitos. 


\section{REFERÊNCIAS ${ }^{5}$}

5 As referências bibliográficas deste trabalho foram elaboradas segundo as normas sugeridas pela ABNT (Associação Brasileira de Normas Técnicas). 
ADES, C. A experiência psicológica da duração. São Paulo: IEA/USP, 1991, p. 6-14, (Coleção Documentos - Série Teoria Política).

ANGRILLI, A.; CHERUBINI, P.; PAVESE, A; MANFREDINI, S. The influence of affective factors on time perception. Perception and Psychophysics, v. 59, n. 6, p. 972-982, 1997.

BALKWILL, L. L.; THOMPSON, W. F. A cross-cultural investigation of the perception of emotion in music: psychophysical and cultural cues. Music Perception v. 17, n. 1, p. 43-64, 1999.

BERLYNE, D. E. Aesthetics and psychobiology. New York: Appleton-CenturyCrofts, 1971

BERLYNE, D. E. Experimental aesthetics. In: New horizons in Psychology. Harmondsworth: Penguin, 1972.

BERLYNE, D. E. The new experimental aesthetics: steps toward an objective psychology of aesthetics appreciation. Washington, D.C.: Hampshire, 1974.

BIGAND, E.; FILIPIC S.; LALITTE, P. The time course of emotional response to music. Annals of the New Academic of Sciences, no prelo.

BIGAND, E.; POULIN-CHARRONAT, B. Are we all "experienced listeners"? Cognition. No prelo.

BIGAND, E.; VIEILLARD, S.; MADURELL, F.; MAROZEAU, J.; DACQUET, A. Multidimensional scaling of emotional responses to music: the effect of musical expertise and of the duration of the excerpts. Cognition and Emotion, v. 19, n. 8, p. 1113-1139, 2005.

BLOCK, R. A.; ZAKAY, D. Prospective and retrospective duration judgments: a metaanalytic review. Psychonomic Bulletin e Review, v. 4, n. 2, p. 184-197, 1997.

BOLTZ, M. Time estimation and attentional perspective. Perception and Psychophysics, v. 49, n. 5, p. 422-433, 1991.

BREGMAN, A. S.; AHAD, P. A.; CRUM, P. A. C.; O'REALLY, J; Effect of time intervals and tone durations on auditory stream segregation. Perception and Psychophysics, v. 62, n. 3, p. 626-636, 2000. 
BUENO, J. L. O. A questão do tempo: tempo biológico, psicológico e espaço-social. In: REUNIÃO ANUAL DA SOCIEDADE BRASILEIRA DE PSICOLOGIA, 15. 1985, Ribeirão Preto. Anais da XV Reunião Anual da Sociedade Brasileira de Psicologia. Ribeirão Preto: Sociedade Brasileira de Psicologia, 1985, p. 197-198.

BUENO J. L.O.; FIRMINO E. A.; ENGELMANN A; Influence of generalized complexity of a musical event on subjective time estimation. Perceptual and Motor Skills, v. 94, p. 541$547,2002$.

BUENO, J. L. O.; RAMOS, D. Musical mode and estimation of time. Perceptual and Motor Skills, v. 105, p. 1087-1092, 2007.

COOKE, D. The language of music. London: Oxford University Press, 1959.

COSTA; M.; FINE, P.; BITTI, P. E. R. Interval distributions, mode, and tonal strength of melodies as predictors of perceived emotion. Music Perception, v. 22, n. 1, p. 1-14, 2004.

DALLA BELLA, S.; PERETZ, I.; ROUSSEAU, L.; GOSSELIN, N. A developmental study of the affective value of tempo and mode in music. Cognition, v. 80, p. B1-B10, 2001.

DAlla BELlA, S.; PERETZ, I.; ROUSSEAU, L.; GOSSELIN, N.; AYOTTE, J.; LAVOIE, A. Development of the happy-sad distinction in music appreciation - Does tempo emerge earlier than mode? Annals of New York Academy of Sciences, v. 930, p. 436-438, 2001.

DROIT-VOLET, S.; BRUNOT, S.; NIEDENTHAL, P. M. Perception of the duration of emotional events. Cognition and Emotion, v. 18, p. 849-858, 2004.

DROIT-VOLET, S; MECK, W. H.; How emotions colour our perception of time. Trends in Cognitive Sciences, v. 11, n. 12, p. 504-513, 2007.

DROIT-VOLET, S; TOURRET, S.; WEARDEN, J. Perception of the duration of auditory and visual stimuli in children and adults. Quarterly Journal of Experimental Psychology, v. 57A, n. 5, p. 797-818, 2004.

EDMONDS, E. M.; CAHOON, D.; BRIDGES, B. The estimation of time as a function of positive, neutral or negative expectancies. Bulletin of the Psychonomic Society, v. 17, n. 6 , p. 259-260, 1981.

EFFRON, D. A.; NIEDENTHAL, P. M.; GIL, S.; DROIT-VOLET, S. Embodied temporal perception of emotion. Emotion, v. 6, p. 1-9, 2006. 
FRANCÈS, R. The perception of music. Translation: W. J. Dowling. Hillsdale, NJ: Erlbaum, 1988.

FRAISSE, P. Psychologie du temps. Paris: Presses Universitaires de France, 1967.

GABRIEL, C. An experimental study of Deryck Cookee's theory of music and meaning. Psychology of Music, v. 24, p. 68-91, 1978.

GABRIELSSON, A. Emotions in strong experiences with music. In: JUSLIN, P. N.; SLOBODA, J. J. (Eds.). Music and emotion: theory and research. New York: Oxford University Press, p. 431-449, 2001;

GABRIELSSON, A.; JUSLIN, P. N. Emotional expression in music. In DAVIDSON, R. J.; K. R. SCHERER; H. H. GOLDSMITH (Eds.). Handbook of Affective Sciences. New York: Oxford University Press, 503-534, 2003.

GABRIELSSON A.; LINDSTRÖM, E. The influence of musical structure on emotional expression. IN: JUSLIN, P. N.; SLOBODA, J. J. (Eds.). Music and emotion: theory and research. New York: Oxford University Press, 223-248, 2001.

GAGNON, L.; PERETZ, I. Mode and tempo relative contribuitions to "happy-sad" judgements in equitone melodies. Cognition and Emotion, v. 17, n. 1, p. 25-40, 2003.

GALVÃO, A. Cognição, emoção e expertise musical. Psicologia: Teoria e Pesquisa, v. 22, n. 2, p. 169-174, 2006.

GAUTIER, T.; DROIT-VOLET, S. Attentional distraction and time perception in children. International Journal of Psychology, v. 37, n. 1, p. 27-34, 2002.

GIBBON, J.; CHURCH, R. M.; MECK, W. H. Scalar timing in memory. Annals of the New York Academy of Sciences, v. 423, p. 52-77, 1984.

GIL, S.; NIEDENTHAL, P.; DROIT-VOLET, S. Anger and temporal perception in children. Emotion, v. 7, n. 1, p. 1-7, 2007.

GOLDIN, R. Harmonic practice in tonal music. New York: Norton, 1997.

GREGORY, A. H.; WORRAL, L.; SARGE, A. The development of emotional responses to music in young children. Motivation and Emotion, v. 20, n. 4, p. 341-348, 1996.

GROUT, D. J.; PALISCA, C. V. História da Música Ocidental. Lisboa, Ed. Gradiva, 1994. 
HARGREAVES, D. J.; CASTELL, K. C. Development of liking for familiar and unfamiliar melodies. In: INTERNATIONAL SEMINAR OF THE INTERNATIONAL SOCIETY FOR MUSIC EDUCATION, 11. 1986, Frankfurt, Germany. Paper presented at the Eleventh International Seminar of the International Society for Music Education. Frankfurt, Germany, 1986.

HEVNER, K. Expression in music: a discussion of experimental studies and theories. Psychological Review, v. 42, p. 186-204, 1935.

HEVNER, K. Experimental studies of the elements of expression in music. American Journal of Psychology, v. 48, p. 246-268, 1936.

HEYDUCK, R. G. Rated preference for musical composition as it relates to complexity and exposure frequency. Perception and Psychophysics, n. 17, p. 84-91, 1975.

HICKS, R. E.; MILlER, G. W.; KINSBOURNE, M. Prospective judgments of time as function of information processed. American Journal of Psychology, v. 89, p. 719-730, 1976.

HINDEMITH, P. Curso condensado de Harmonia Tradicional. Rio de Janeiro, Irmãos Vitale, 1944.

JǿRGENSEN, H. The psychology of the music experience. Oslo: Norsk Musikforlag, 1988.

JUSLIN, P. N. Emotional communication in music viewed through a Brunswikian lens. In: KLEINEN, G. (Ed.). Musical expression: proceedings of the conference of ESCOM and DGM. Bremen, Germany: University of Bremen, 21-25, 1995.

JUSLIN, P. N. Cue utilization in communication of emotion in music performance: relating performance to perception. Journal of Experimental Psychology: Human Perception and Performance, v. 26, p. 1797-1813, 2000.

JUSLIN, P. N. From mimesis to catharsis: expression, perception and induction of emotion in music. In: MIELL, D.; MCDONALD, R.; HARGREAVES, D. J. Musical communication. New York: Oxford University Press, p. 85-114, 2005.

JUSLIN, P. N.; LAUKKA, P. Communication of emotions in vocal expression and music performance: different channels, same code? Psychological Bulletin, v. 129, p. 770-814, 2003. 
JUSLIN, P. N.; LAUKKA, P. Expression, perception and induction of musical emotions: a review and a questionnaire study of everyday listening. Journal of New Music Research, v. 33, n. 3, p. 217-238, 2004.

JUSLIN, P. N.; SLOBODA, J. A. Music and emotion: theory and research. New York: Oxford University Press, 2001.

JUSLIN, P. N.; VÄSTFJÄLL, D. Emotional responses to music: the need to consider underlying mechanisms. Behavioral and Brain Sciencess ${ }_{2}$ in press.

KHALFA, S.; PERETZ, I.; BLONDIN, J. P.; ROBERT, M. Event-related skin conductance responses to musical emotions in humans. Neuroscience Letters, v. 328, p. 145-149, 2002.

KIVY, P. The corded shell: reflexions on musical expression. Princeton, NJ: Princeton University Press, 1980.

KOELSCH, S.; GUNTER, T.; FRIEDERICI, A. D.; SCHRÖEGER, E. S. Brain indices of music processing: 'nonmusicians' are musical. Journal of Cognitive Neurosciences, v. 12, p. 520-541, 2000.

KONEČNI, V. J. Social interaction and musical preference. In: DEUTSCH, D. (Ed.). The Psychology of Music. New York: Academic Press, 1982.

KRUMHANSL, C. L. Cognitive foundations of musical pitch. New York: Oxford University Press, 1990.

KRUMHANSL, C. L. An exploratory study of musical emotions and psychophysiology. Canadian Journal of Experimental Psychology, v. 51, p. 336-352, 1997.

LANGER, S. K. Philosophy in a new key. New York: New York American Library, 1957.

LARSEN, J. T; DIENER, E. Promisses and problems with the circumplex model of emotion. In: CLARKE, M. S. (Ed.). Review of personality and Social Psychology. Newbury Park: Sarge, 1992, v. 14, p. 25-59.

LARSEN, J. T.; McGRAW, A. P.; CACIOPPO, J. T. Can people feel happy and sad at the same time? Journal of Personality and Social Psychology, v. 81, p. 684-696, 2001.

LEVINE, M. The jazz piano book. San Francisco: Hal Leonard Books, 1989. 
LOVELOCK, W. História concisa da música. São Paulo: Martins Fontes, 2001.

MANDLER, G. (1984). Music and body: psychology of emotion and stress. New York: Norton.

MEYER, L. (1956). Emotion and meaning in music. Chicago: University of Chicago press.

ORME, F. Estimating the duration of sexual behavior: a laboratory analog study. Archives of sexual behavior, p. 329-335, 1969.

ORNSTEIN, R. E. On the experience of time. Harmondsworth, U. K.: Penguin, 1969.

PARNCUTT, R. Tonality as implication-realization. In: VOS, P.; LEMAN, M. (Eds.). Proceedings of Expert Meeting on Tonality Induction. New York: Oxford University Press, p. 121-141, 1999.

PAZ, E. O modalismo na música brasileira. Brasília: Musimed, 2002.

PERETZ, I. Brain specialization for music. The Neuroscientist, v. 8-4, p. 372-380.

PERETZ, I.; ZATORRE, R. The cognitive neuroscience of music. New York: Oxford University Press, 2003.

PERSICHETTI, V. Twentieth-Century Harmony. New York: Norton, 1996.

RAMOS, D. Tempo subjetivo e música: fatores afetivos na música modal influenciam a estimação subjetiva do tempo. 2004. Dissertação (Mestrado em Psicologia) - Faculdade de Filosofia, Ciências e Letras de Ribeirão Preto, Universidade de São Paulo, Ribeirão Preto, 2004.

RAMOS, D.; BUENO, J. L. O.; BIGAND, E. Manipulating ecclesiastic musical modes and tempo results in continuous changes in perceived musical emotion along arousal and valence dimensions. European Journal of Cognitive Psychology, in press.

RIGG, M. G. Speed as determiner of musical mood. Journal of Experimental Psychology, v. 27, p. 566-571, 1940.

ROBINSON, J. Music and meaning. Ithaca, NY: Cornell University Press, 1997. 
ROBAZZA, C.; MACALUSO, C.; D'URSO, V. Emotional reactions to music by gender, age and expertise. Perceptual and Motors Skills, v. 79, p. 939-944, 1994.

ROSS, D.; CHOI, J.; PURVES, D. Musical intervals in speech. Procedings of the National Academy of Sciences of the United States of America, v. 104, n. 23, p. 9852-9857, 2007.

RUSSEL, P. A. Affective space is bipolar. Journal of Personality and Social Psychology, v. 37, p. 345-356, 1979.

RUSSEL, P. A. A circumplex model of affect. Journal of Personality and Social Psychobiology, v. 39, p. 1161-1178, 1980.

SCHERER, K. R.; OSHINSKY, J. S. Cue utilization in emotion attribution from auditory stimuli. Motivation and emotion, v. 1, p. 331-346, 1977.

SCHERER, K. R.; ZENTNER, M. R. Emotional effects of music: production rules. In: JUSLIN, P. N.; SLOBODA, J. A. (Eds.). Music and emotion: theory and research. New York: Oxford University Press, 2001, p. 361-392.

SCHÖENBERG, A. Harmonia. São Paulo: Editora UNESP, 2002.

SHIFF, W.; THAYER, S. Cognitive and affective factors in temporal experience: anticipated or experienced pleasant and unpleasant sensory events. Perceptual and Motors Skills, v. 26, p. 799-808, 1968.

SLOBODA, J. A. Music structure and emotional response: some empirical findings. Psychology of Music, v. 19, p. 110-120, 1991.

STEINBEIS, N.; KOELSCH, S.; SLOBODA, J. A. The role of harmonic expectancy violations in musical emotions: evidence from subjective, physiological, and neutral responses. Journal of Cognitive Neuroscience, v. 18, p. 1380-1393, 2006.

TRAINOR, L. J.; HEINMILLER, B. M. The development of evaluative responses to music: infants prefer to listen to consonance over dissonance. Progress in Natural Sciences, v. 21, n. 1, p. 77-88, 1998.

WATERMAN, M. Emotional responses to music: implicit and explicit effects in listeners and performers. Psychology of Music, v. 24, p. 53-67, 1996.

WATTS, F. N.; SHARROCK, R. Fear and time estimation. Perceptual and Motors Skills, v. 59, p. 597-598, 1984. 
WEBSTER, G. D.; WEIR, C. G. Emotional responses to music: interactive effects of mode, texture and tempo. Motivation and Emotion, v. 29, n. 1, p. 19-39, 2005.

WISNIK, J. M. O som e o sentido: uma outra história das músicas. São Paulo: Companhia das Letras, 2004.

ZAKAY, D. The evasive art of subjective time measurement: some methodological dilemmas. In: BLOCK, R. A. Cognitive models of psychological time. New. Jersey: Lea Publishers, 1990, p. 59-84. 
6. APÊNDICES 


\section{APÊNDICE A}

Questionários experimentais 


\section{QUESTIONÁRIO DE COLETA \\ EXPERIMENTO I - MÚSICOS}

\section{Código do Participante:}

\section{Data:}

\section{Início e Término:}

\section{Dados pessoais}

a. Nome:

b. Telefone para contato:

c. E-mail para contato:

d. Data de nascimento: de de

e. Sexo:

f. Nacionalidade:

g. Lugar onde residiu durante a maior parte da vida:

h. Formação acadêmica:

i. Curso / Profissão:

j. Considera a sua audição boa?

2. Dados relacionados à experiência musical do participante

a. Quais instrumentos musicais você toca?

b. Há quanto tempo você possui estudo sistematizado em algum instrumento musical?

c. Descreva brevemente sua trajetória como estudante de música.

d. Em qual instrumento musical você desenvolve suas maiores habilidades? 
e. Quantas horas de estudo musical diário você pratica normalmente? Em qual instrumento?

f. Em média, quantas horas de música você escuta por dia?

g. Quais os gêneros de música que mais costuma ouvir?

\section{Dados relacionados ao Experimento}

a. O que você achou das músicas apresentadas?

b. Durante o experimento, quais recursos você utilizou para associar as emoções analisadas aos trechos musicais que você escutou?

c. De maneira geral, você conhecia os trechos musicais? Caso a resposta seja afirmativa, poderia nomear alguns?

d. As músicas fizeram você lembrar de alguma coisa? Caso a resposta seja afirmativa, poderia descrever sobre algumas lembranças que você teve durante as escutas?

e. Qual a sua motivação ou interesse para participar deste experimento? 
f. O que mais lhe chamou atenção no estudo?

g. Na sua opinião, qual é o objetivo deste estudo? Você formulou alguma hipótese durante o experimento?

h. Tem algum comentário ou sugestão a fazer?

O B R I G A D O ! 


\section{QUESTIONÁRIO DE COLETA}

\section{EXPERIMENTO I - NÃO MÚSICOS}

\section{Código do Participante:}

\section{Data:}

\section{Início e Término:}

\section{Dados pessoais}

a. Nome:

b. Telefone para contato:

c. E-mail para contato:

d. Data de nascimento: de de

e. Sexo:

f. Nacionalidade:

g. Lugar onde residiu durante a maior parte da vida:

h. Formação acadêmica:

i. Curso / Profissão:

j. Considera a sua audição boa?

1. Dados relacionados à experiência musical do participante

a. Já teve aulas de música? Em que modalidade ou instrumento?

No caso de resposta negativa à questão anterior, ir diretamente o item “2. f.”.

b. Durante quanto tempo você teve aulas de música?

c. Quantos anos você tinha quando começou a estudar música? 
d. Descreva brevemente sua trajetória como estudante de música.

e. Quantas horas de estudo musical diário você praticava normalmente? E quantas horas você ainda pratica hoje?

f. Em média, quantas horas de música você escuta por dia?

g. Quais os gêneros de música que mais costuma ouvir?

\section{Dados relacionados ao Experimento}

a. O que você achou das músicas apresentadas?

b. Durante o experimento, quais recursos você utilizou para associar as emoções analisadas aos trechos musicais que você escutou?

c. De maneira geral, você conhecia os trechos musicais? Caso a resposta seja afirmativa, poderia nomear alguns?

d. As músicas fizeram você lembrar de alguma coisa? Caso a resposta seja afirmativa, poderia descrever sobre algumas lembranças que você teve durante as escutas? 
e. Qual a sua motivação ou interesse para participar deste experimento?

f. O que mais lhe chamou atenção no estudo?

g. Na sua opinião, qual é o objetivo deste estudo? Você formulou alguma hipótese durante o experimento?

h. Tem algum comentário ou sugestão a fazer?

O B R I G A D O ! 


\section{QUESTIONÁRIO DE COLETA}

\section{EXPERIMENTO II - MÚSICOS}

\section{Código do Participante: ___ Data:}

\section{Início / Término:}

\section{Dados pessoais}

a. Nome:

b. Telefone / E-mail para contato:

c. Data de nascimento: d. Sexo:

e. Nacionalidade:

f. Curso:

g. Período: ano

\section{Dados relacionados à experiência musical do participante}

a. Instrumento Musical:

b. Estudo o meu instrumento musical há mais ou menos anos

c. Quantos anos você tinha quando começou a estudar música?

d. Hoje em dia, quantas horas de música você pratica ou estuda por dia?

\section{Dados relacionados ao Experimento}

a. Durante o experimento, qual recurso você utilizou para associar as músicas às durações apresentadas?

b. De maneira geral, você conhecia os trechos musicais? Poderia nomear alguns?

c. Na sua opinião, qual é o objetivo deste estudo?

d. Tem algum comentário ou sugestão a fazer? 


\section{QUESTIONÁRIO DE COLETA}

\section{EXPERIMENTO II - NÃO MÚSICOS}

Código do Participante:

Data:

\section{Início / Término:}

\section{Dados pessoais}

a. Nome:

b. Telefone / E-mail para contato:

c. Data de nascimento:

d. Sexo:

e. Nacionalidade:

f. Curso:

g. Período: ano

2. Dados relacionados à experiência musical do participante

a. Já teve aulas de música? Em qual instrumento?

b. Durante quanto tempo você teve aulas de música?

c. Quantos anos você tinha quando começou a estudar música?

d. Hoje em dia, quantas horas de música você pratica ou estuda por dia?

\section{Dados relacionados ao Experimento}

a. Durante o experimento, qual recurso você utilizou para associar as músicas às durações apresentadas?

b. De maneira geral, você conhecia os trechos musicais? Poderia nomear alguns?

c. Na sua opinião, qual é o objetivo deste estudo?

d. Tem algum comentário ou sugestão a fazer?

O B R I G A D O ! 


\section{QUESTIONÁRIO DE COLETA}

\section{EXPERIMENTO III - MÚSICOS}

\section{Código do Participante:}

\section{Data:}

\section{Início e Término:}

\section{Dados pessoais}

a. Nome:

b. Telefone para contato:

c. E-mail para contato:

d. Data de nascimento: de de

e. Sexo:

f. Nacionalidade:

g. Lugar onde residiu durante a maior parte da vida:

h. Formação acadêmica:

i. Curso / Profissão:

j. Considera a sua audição boa?

2. Dados relacionados à experiência musical do participante

a. Quais instrumentos musicais você toca?

b. Há quanto tempo você possui estudo sistematizado em algum instrumento musical?

c. Descreva brevemente sua trajetória como estudante de música.

d. Em qual instrumento musical você desenvolve suas maiores habilidades? 
e. Quantas horas de estudo musical diário você pratica normalmente? Em qual instrumento?

f. Em média, quantas horas de música você escuta por dia?

g. Quais os gêneros de música que mais costuma ouvir?

\section{Dados relacionados ao Experimento}

a. O que você achou das músicas apresentadas?

b. Durante o experimento, quais recursos você utilizou para associar as emoções analisadas aos trechos musicais que você escutou?

c. De maneira geral, você conhecia os trechos musicais? Caso a resposta seja afirmativa, poderia nomear alguns?

d. As músicas fizeram você lembrar de alguma coisa? Caso a resposta seja afirmativa, poderia descrever sobre algumas lembranças que você teve durante as escutas?

e. Qual a sua motivação ou interesse para participar deste experimento?

f. O que mais lhe chamou atenção no estudo? 
g. Na sua opinião, qual é o objetivo deste estudo? Você formulou alguma hipótese durante o experimento?

h. Tem algum comentário ou sugestão a fazer?

O B R I G A D O ! 


\section{QUESTIONÁRIO DE COLETA}

\section{EXPERIMENTO III - NÃO MÚSICOS}

\section{Código do Participante:}

\section{Data:}

\section{Início e Término:}

\section{Dados pessoais}

a. Nome:

b. Telefone para contato:

c. E-mail para contato:

d. Data de nascimento: de de

e. Sexo:

f. Nacionalidade:

g. Lugar onde residiu durante a maior parte da vida:

h. Formação acadêmica:

i. Curso / Profissão:

j. Considera a sua audição boa?

2. Dados relacionados à experiência musical do participante

a. Já teve aulas de música? Em que modalidade ou instrumento?

No caso de resposta negativa à questão anterior, ir diretamente o item “2. f.”.

b. Durante quanto tempo você teve aulas de música?

c. Quantos anos você tinha quando começou a estudar música?

d. Descreva brevemente sua trajetória como estudante de música. 
e. Quantas horas de estudo musical diário você praticava normalmente? E quantas horas você ainda pratica hoje?

f. Em média, quantas horas de música você escuta por dia?

g. Quais os gêneros de música que mais costuma ouvir?

\section{Dados relacionados ao Experimento}

a. O que você achou das músicas apresentadas?

b. Durante o experimento, quais recursos você utilizou para associar as emoções analisadas aos trechos musicais que você escutou?

c. De maneira geral, você conhecia os trechos musicais? Caso a resposta seja afirmativa, poderia nomear alguns?

d. As músicas fizeram você lembrar de alguma coisa? Caso a resposta seja afirmativa, poderia descrever sobre algumas lembranças que você teve durante as escutas?

e. Qual a sua motivação ou interesse para participar deste experimento? 
f. O que mais lhe chamou atenção no estudo?

g. Na sua opinião, qual é o objetivo deste estudo? Você formulou alguma hipótese durante o experimento?

h. Tem algum comentário ou sugestão a fazer?

O B R I G A D O ! 


\section{QUESTIONÁRIO DE COLETA}

\section{EXPERIMENTO IV - MÚSICOS}

Código do Participante:

Data:

\section{Início / Término:}

\section{Dados pessoais}

a. Nome:

b. Telefone / E-mail para contato:

c. Data de nascimento: d. Sexo:

e. Nacionalidade: f. Curso:

g. Período: ano

\section{Dados relacionados à experiência musical do participante}

a. Instrumento Musical:

b. Estudo o meu instrumento musical há mais ou menos anos

c. Quantos anos você tinha quando começou a estudar música?

d. Hoje em dia, quantas horas de música você pratica ou estuda por dia?

\section{Dados relacionados ao Experimento}

a. Durante o experimento, qual recurso você utilizou para associar as músicas às durações apresentadas?

b. De maneira geral, você conhecia os trechos musicais? Poderia nomear alguns?

c. Na sua opinião, qual é o objetivo deste estudo?

d. Tem algum comentário ou sugestão a fazer?

O B R I G A D O ! 


\section{QUESTIONÁRIO DE COLETA}

\section{EXPERIMENTO IV - NÃO MÚSICOS}

\section{Código do Participante:}

Data:

\section{Início / Término:}

1. Dados pessoais

a. Nome:

b. Telefone / E-mail para contato:

c. Data de nascimento: d. Sexo:

e. Nacionalidade: f. Curso:

g. Período: ano

\section{Dados relacionados à experiência musical do participante}

a. Já teve aulas de música? Em qual instrumento?

b. Durante quanto tempo você teve aulas de música?

c. Quantos anos você tinha quando começou a estudar música?

d. Hoje em dia, quantas horas de música você pratica ou estuda por dia?

\section{Dados relacionados ao Experimento}

a. Durante o experimento, qual recurso você utilizou para associar as músicas às durações apresentadas?

b. De maneira geral, você conhecia os trechos musicais? Poderia nomear alguns?

c. Na sua opinião, qual é o objetivo deste estudo?

d. Tem algum comentário ou sugestão a fazer?

O B R I G A D O ! 


\section{APÊNDICE B}

Trechos musicais - Experimentos I e II 


\section{Trechos musicais empregados - Experimento I}

\begin{tabular}{|c|c|c|}
\hline Trecho Musical & Título da obra & Compositor \\
\hline Trecho Musical 1 & Also sprach Zarathustra & R. Strauss \\
\hline Trecho Musical 2 & Waltz Op. $70, n^{\circ} 03$ & F. Chopin \\
\hline Trecho Musical 3 & Piano Concerto K 488 (adágio) & W. A. Mozart \\
\hline Trecho Musical 4 & Violin Concerto (adágio) & J. Brahms \\
\hline Trecho Musical 5 & Sonata (A) for Harpsichord K 208 & D. Scarlatti \\
\hline Trecho Musical 6 & Träumerei, Op. $15, n^{\circ} 07$ & R. Schumann \\
\hline Trecho Musical 7 & Sonata for piano Op. $18, n^{\circ} 03$ & S. Prokofièv \\
\hline Trecho Musical 8 & Trio 2 for piano, violin and cello (largo) & D. Shostakovitch \\
\hline Trecho Musical 9 & Tristan, act 03 & W. R. Wagner \\
\hline Trecho Musical 10 & Symphony Bdur, Hob 1, 105 (andante) & J, Haydn \\
\hline Trecho Musical 11 & Poème Symphonique & $\mathrm{F}$. Liszt \\
\hline Trecho Musical 12 & Gnossiènne $n^{\circ} 02$ & É. Satie \\
\hline Trecho Musical 13 & Hungarian Rapsody $n^{\circ} 02$ & F. Liszt \\
\hline Trecho Musical 14 & That certain feeling & G. Gershwin \\
\hline Trecho Musical 15 & Italian Symphony, 1st movement & F. Mendelsohn \\
\hline Trecho Musical 16 & Prèlude $n^{\circ} 24$ & F. Chopin \\
\hline Trecho Musical 17 & Tasso Lamento \& Triomfo & F. Liszt \\
\hline Trecho Musical 18 & Tod und Verklärung 7' to 7'36 & R. Strauss \\
\hline Trecho Musical 19 & Violin Sonata & J. S. Bach \\
\hline Trecho Musical 20 & Scherzo - A truta (presto) & F. Schubert \\
\hline Trecho Musical 21 & Suíte française G - Sarabande & J. S. Bach \\
\hline Trecho Musical 22 & Duetto for two flutes in F (lamentabile) & J. S. Bach \\
\hline Trecho Musical 23 & Trio for piano, violin and horn, 2nd movement (moderato) & J. Brahms \\
\hline Trecho Musical 24 & Petrouchka & I. Stravinsky \\
\hline Trecho Musical 25 & Erwartung & A. Schöenberg \\
\hline Trecho Musical 26 & Trio 2 for violin, cello and piano (moderato) & D. Shostakovitch \\
\hline Trecho Musical 27 & Totentanz & F. Liszt \\
\hline Trecho Musical 28 & O tambor dos granadeiros & L. Chapí \\
\hline Trecho Musical 29 & Violin romance & L. V. Beethoven \\
\hline Trecho Musical 30 & Valse in E minor - póstuma (vivace) & F. Chopin \\
\hline
\end{tabular}

\section{Trechos musicais empregados - Experimento II}

\begin{tabular}{|c|c|c|c|}
\hline \multicolumn{2}{|c|}{ Músicas } & Emoções & Nova Nomenclatura \\
\hline Número & Título & & \\
\hline & & & ALE 01 \\
\hline 10 & Symphony Bdur, Hob 1 105, Andante - Haydn & Alegria & ALE 02 \\
\hline 13 & Hungarian Rapsody n 02 - Liszt & Alegria & ALE 03 \\
\hline 14 & That certain feeling - Gershwin & Alegria & SER 01 \\
\hline 2 & Waltz, Op. 70, n $^{\circ}$ 03 - Chopin & Serenidade & SER 02 \\
\hline 4 & Violin Concerto Adágio - Brahms & Serenidade & SER 03 \\
\hline 29 & Violin Romance - Beethoven & Serenidade & TRI 01 \\
\hline 3 & Piano Concerto Adágio, K 488 - Mozart & Tristeza & TRI 02 \\
\hline 12 & Gnossienne n 02 - Satie & Tristeza & TRI 03 \\
\hline 25 & Erwartung - Shöenberg & Tristeza & MRV 01 \\
\hline 18 & Tod and Verklärung, 7' - 7'30 - R. Strauss & Medo / Raiva & MRV 02 \\
\hline 26 & Trio 2 for violin, cello and piano, moderato - Shostakovitch & Medo / Raiva & MRV 03 \\
\hline 27 & Totentanz - Liszt & Medo / Raiva & \\
\hline
\end{tabular}




\section{APÊNDICE C}

Partituras musicais - Experimentos III e IV 


\section{Trecho musical 01 - Modo Lídio}
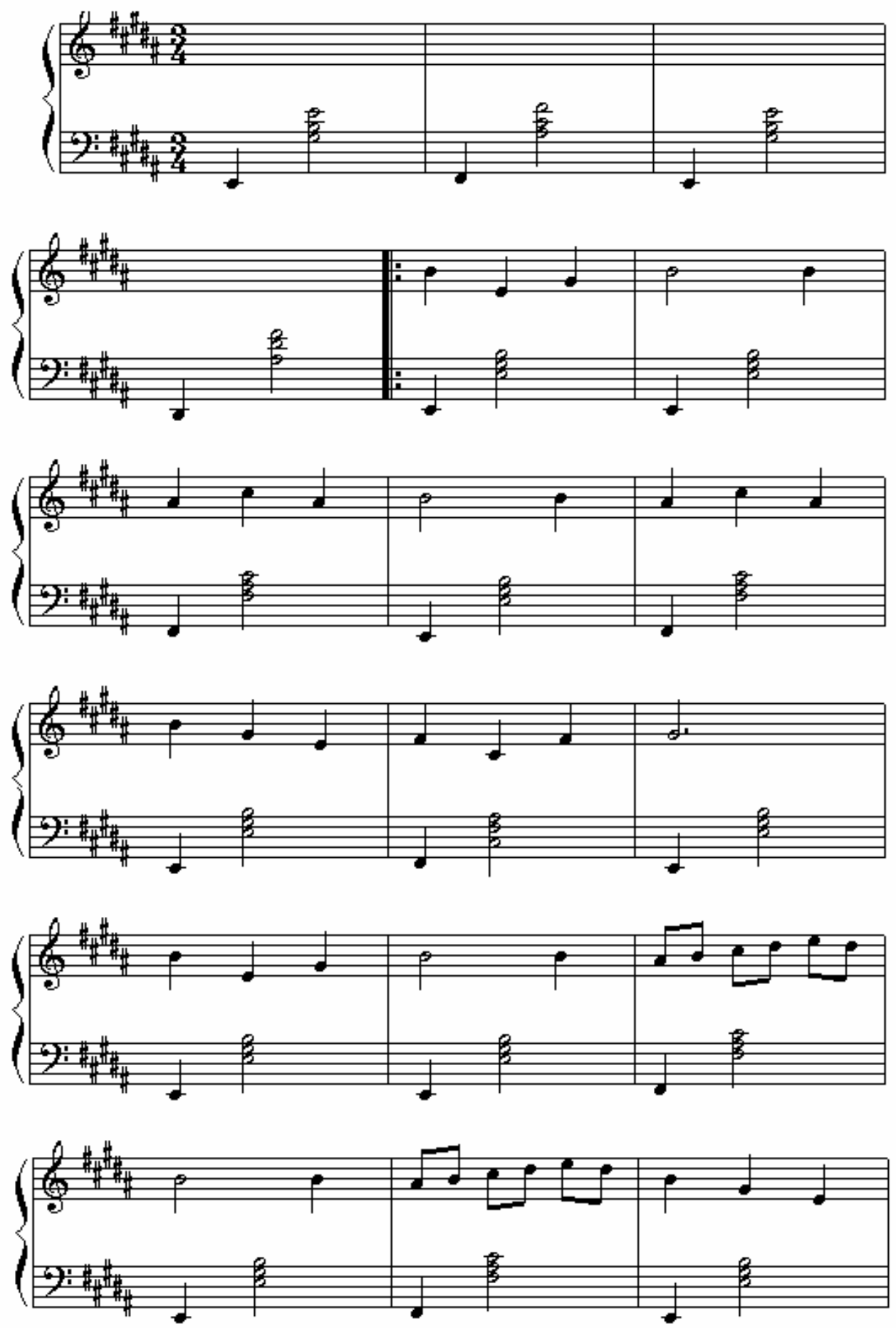

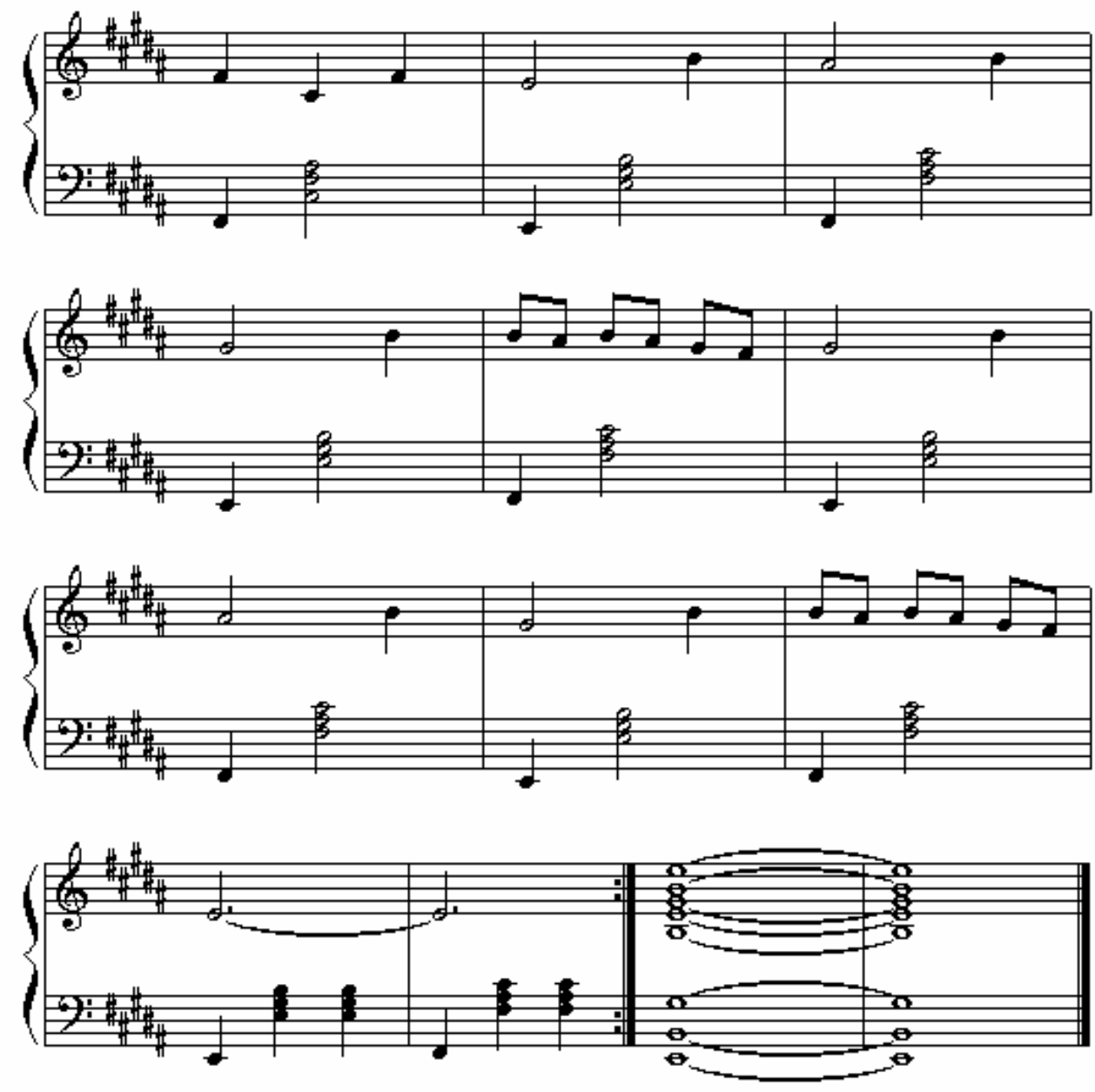


\section{Trecho musical 01 - Modo Jônio}
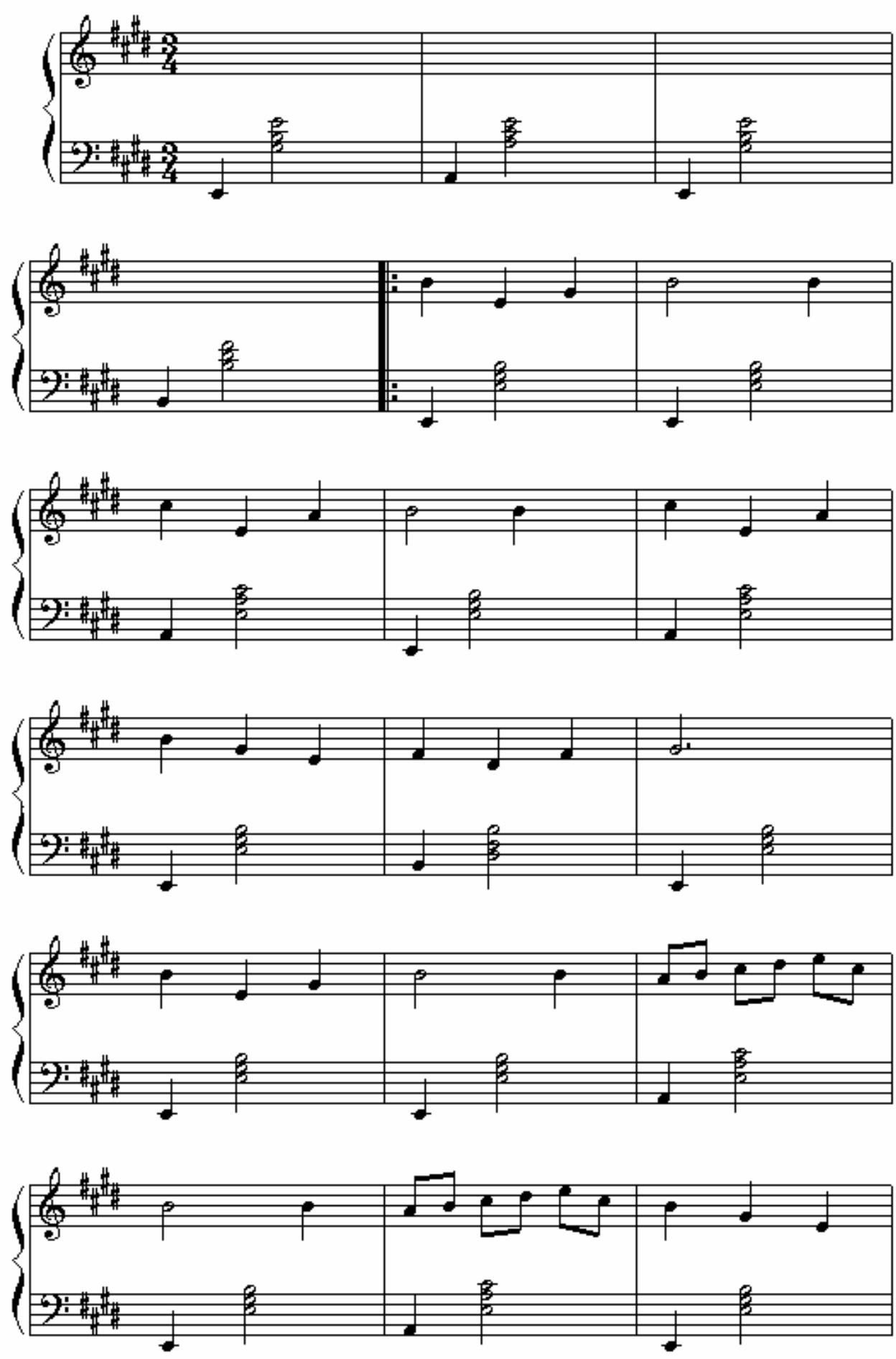

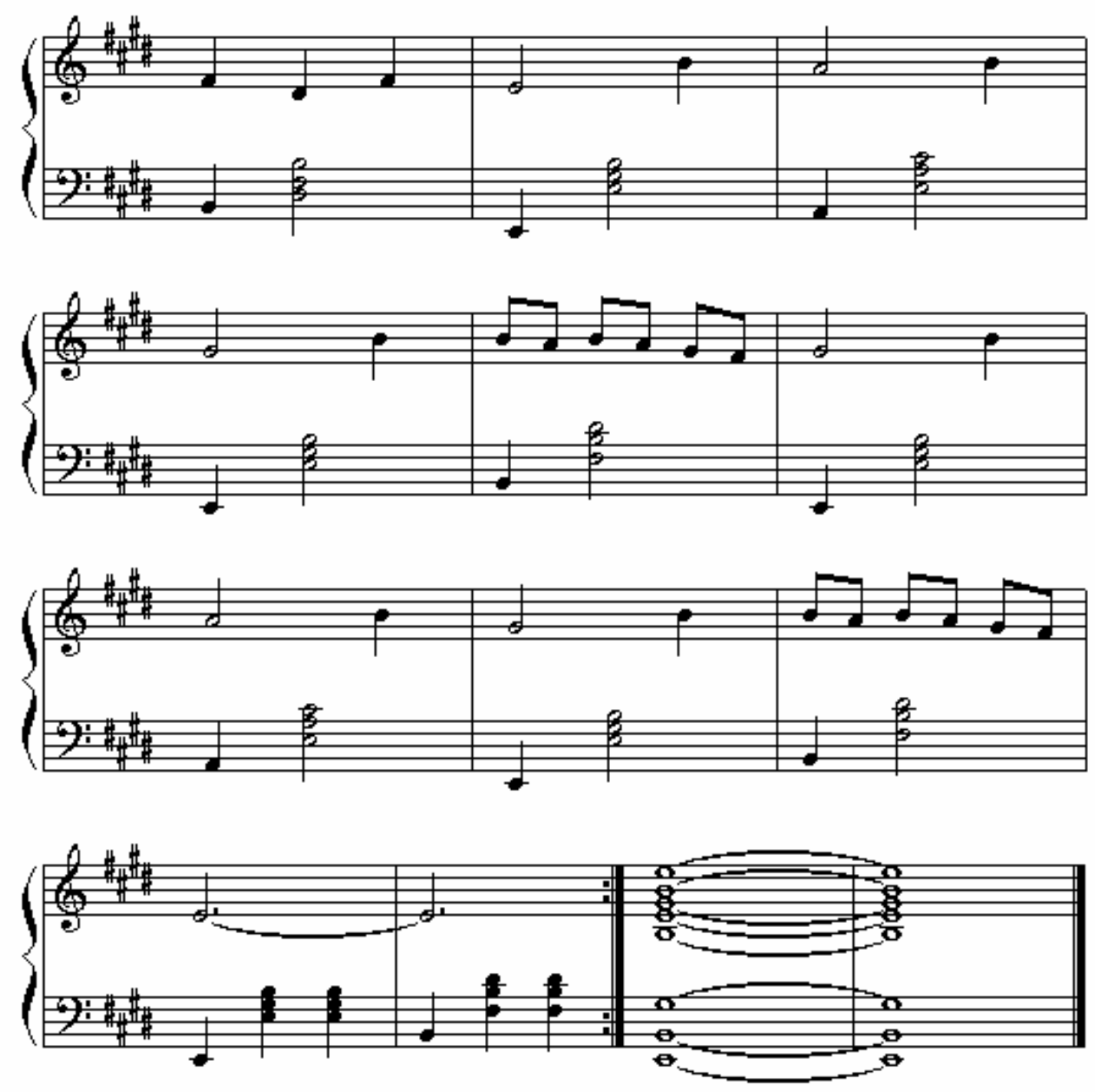
Trecho musical 01 - Modo Mixolídio
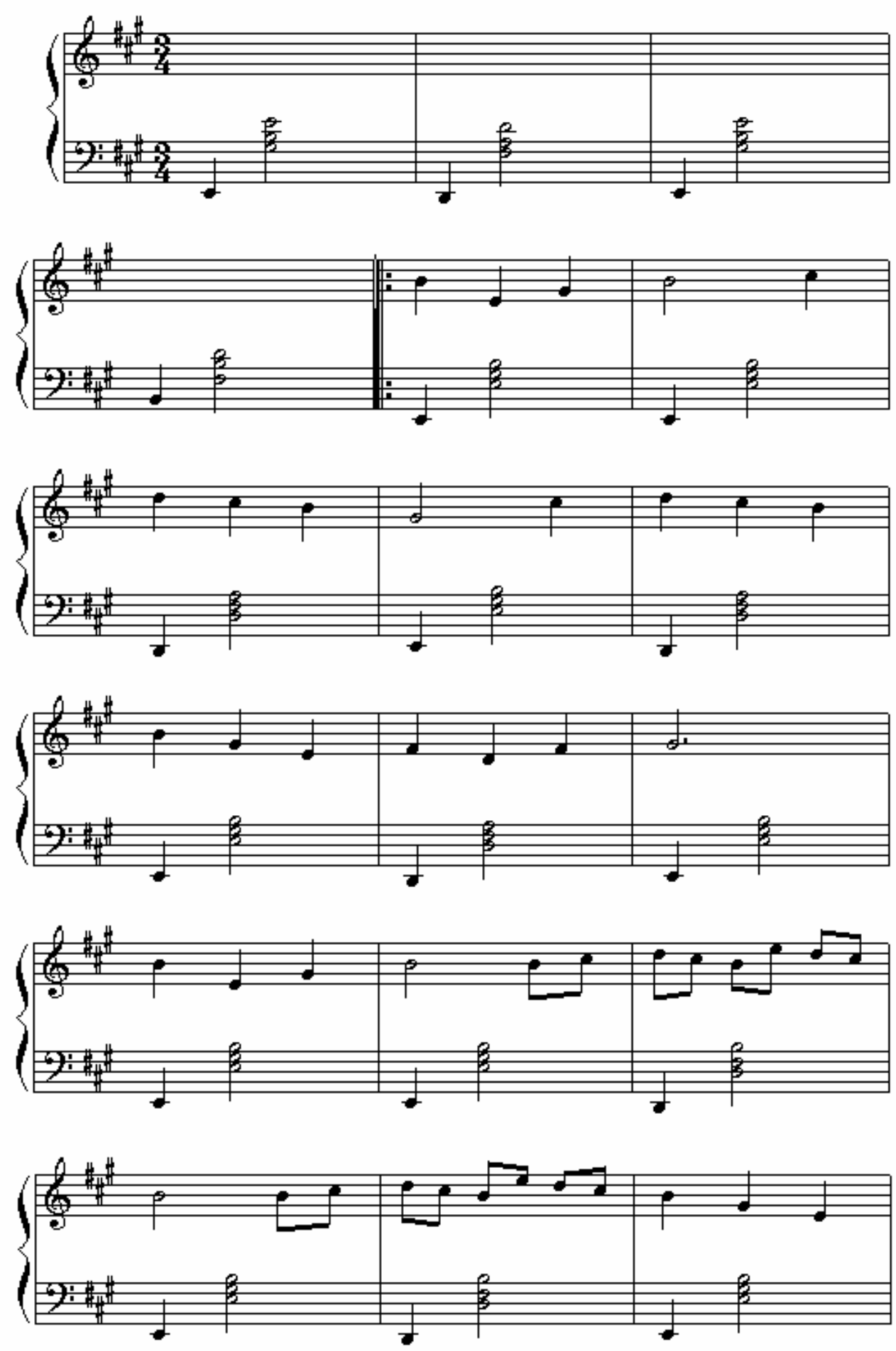

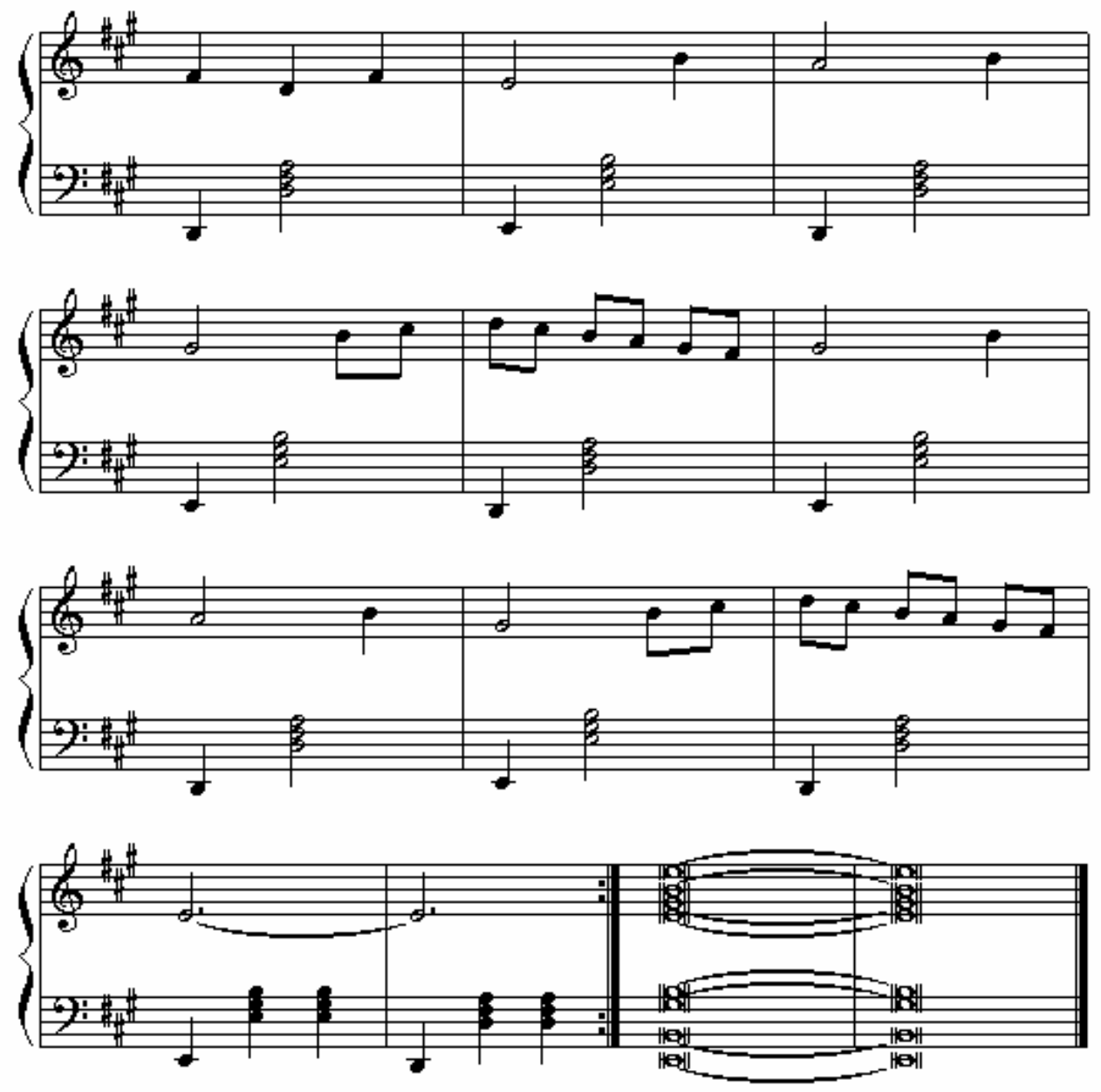
Trecho musical 01 - Modo Dórico
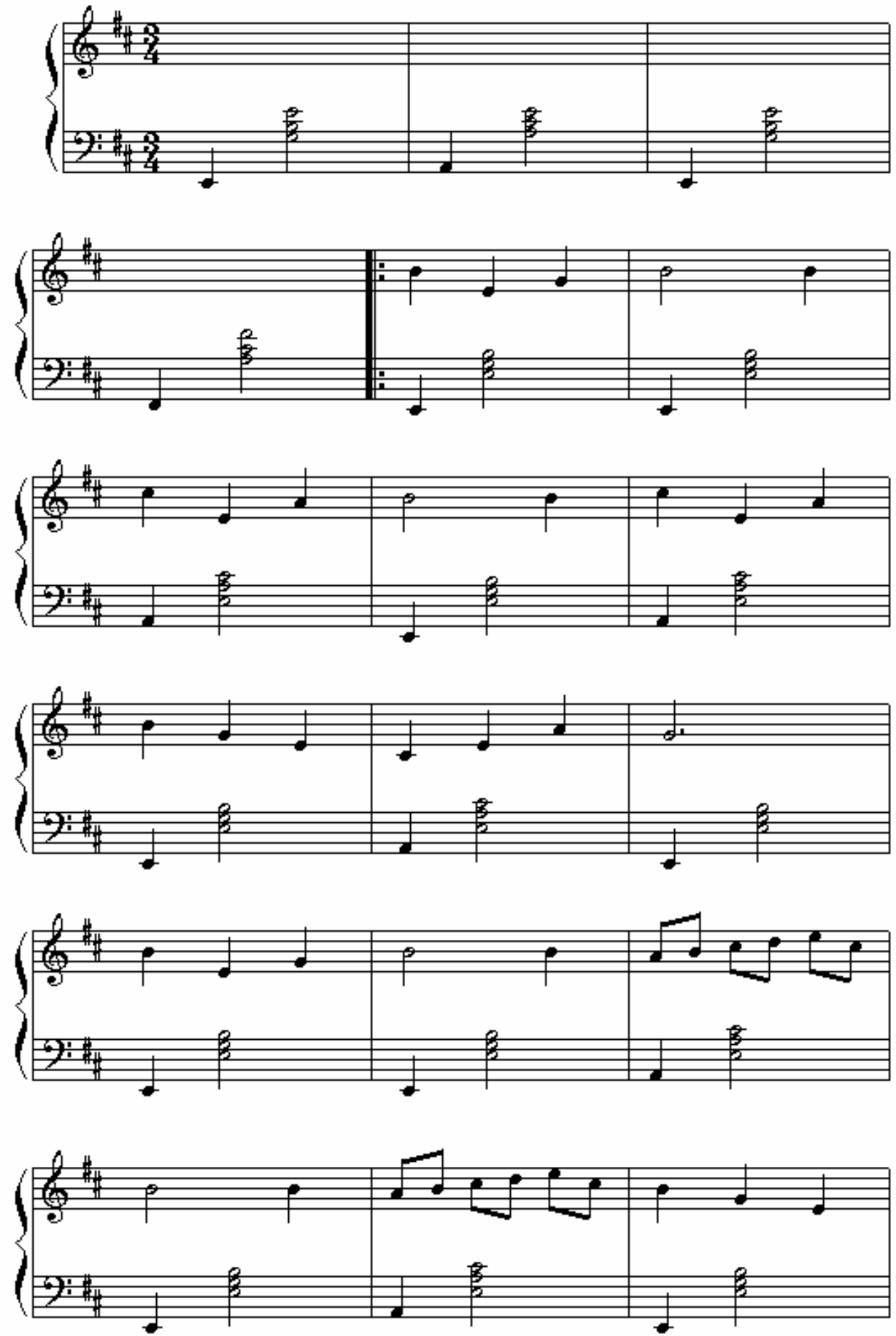

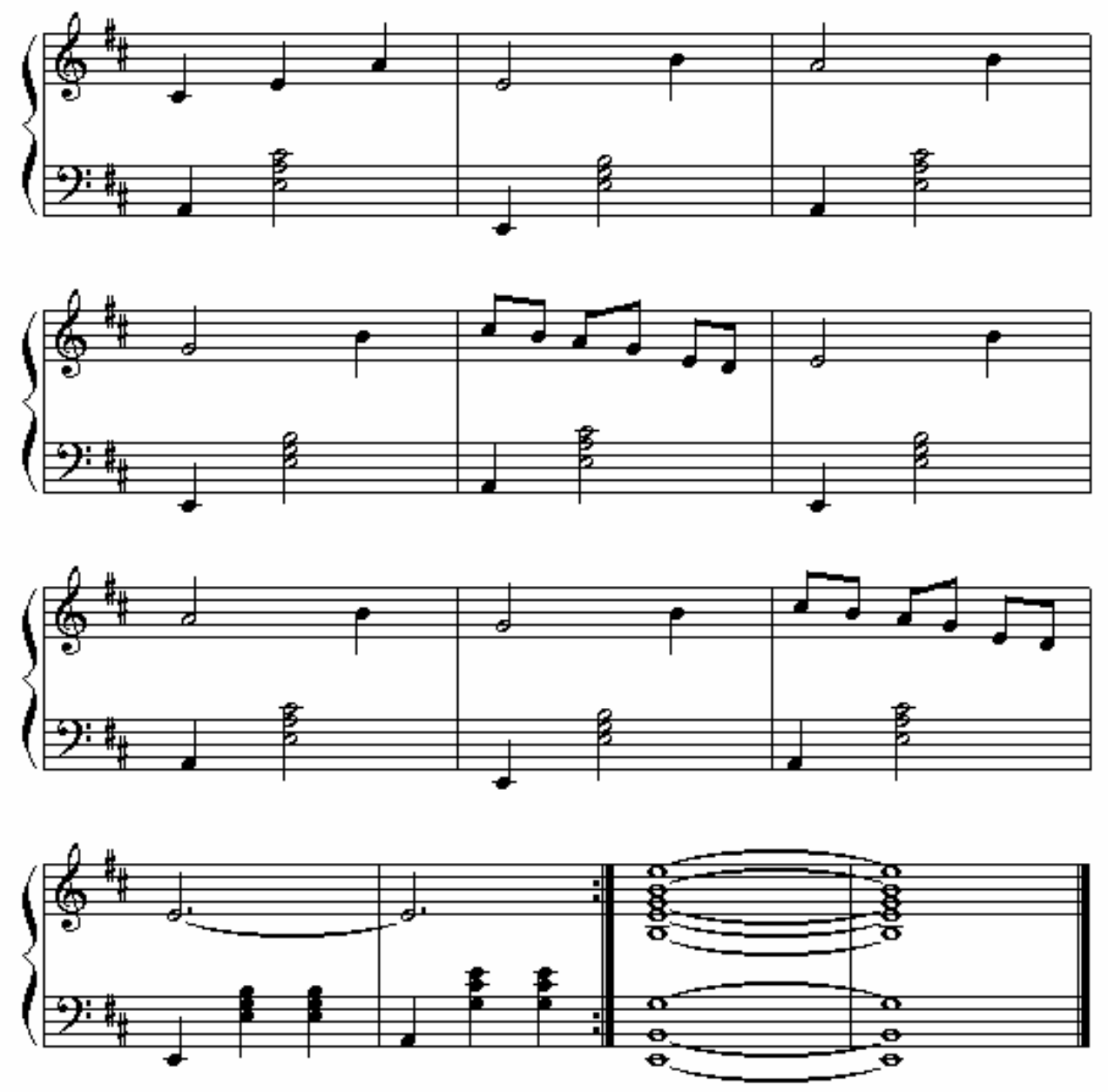


\section{Trecho musical 01 - Modo Eólio}
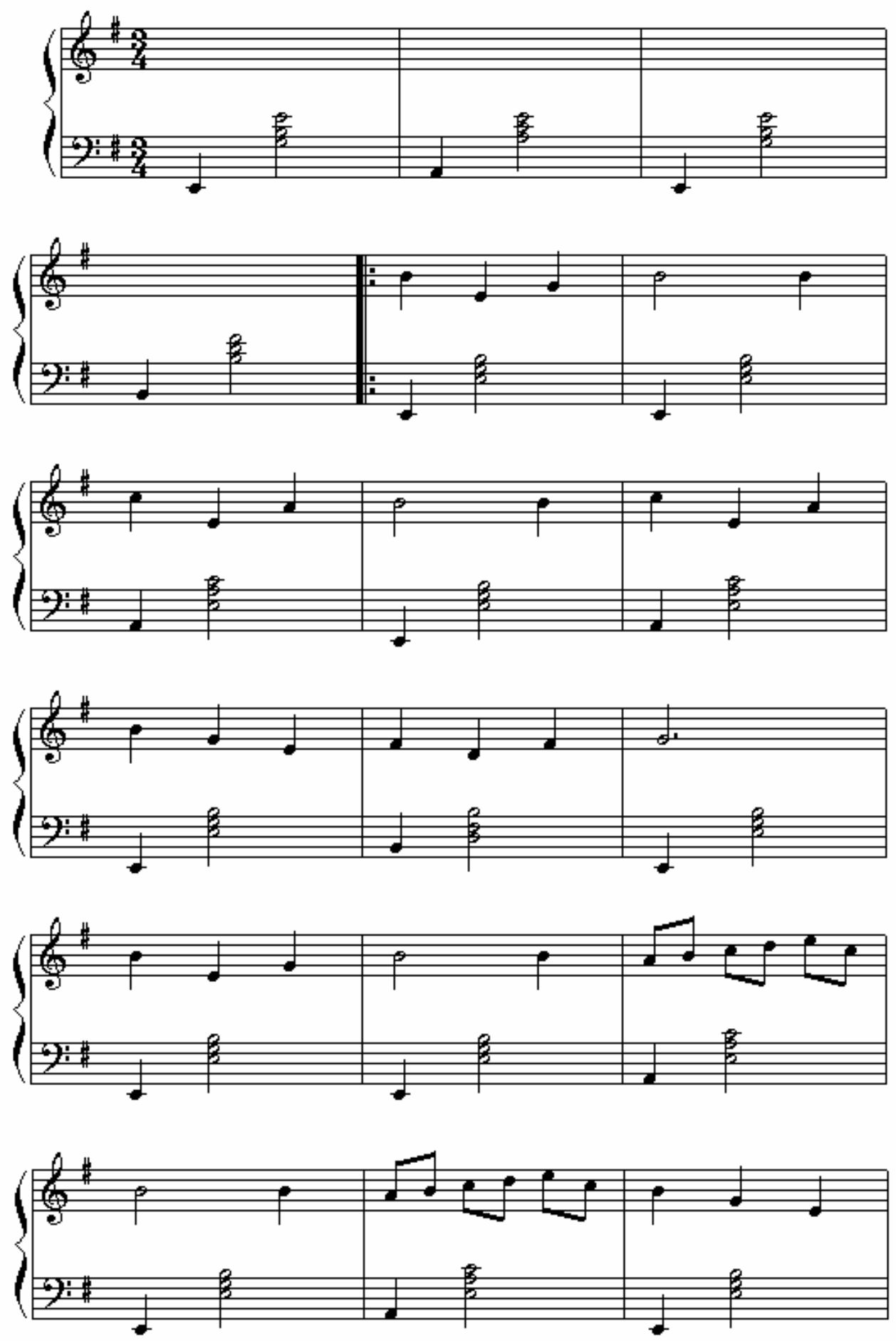

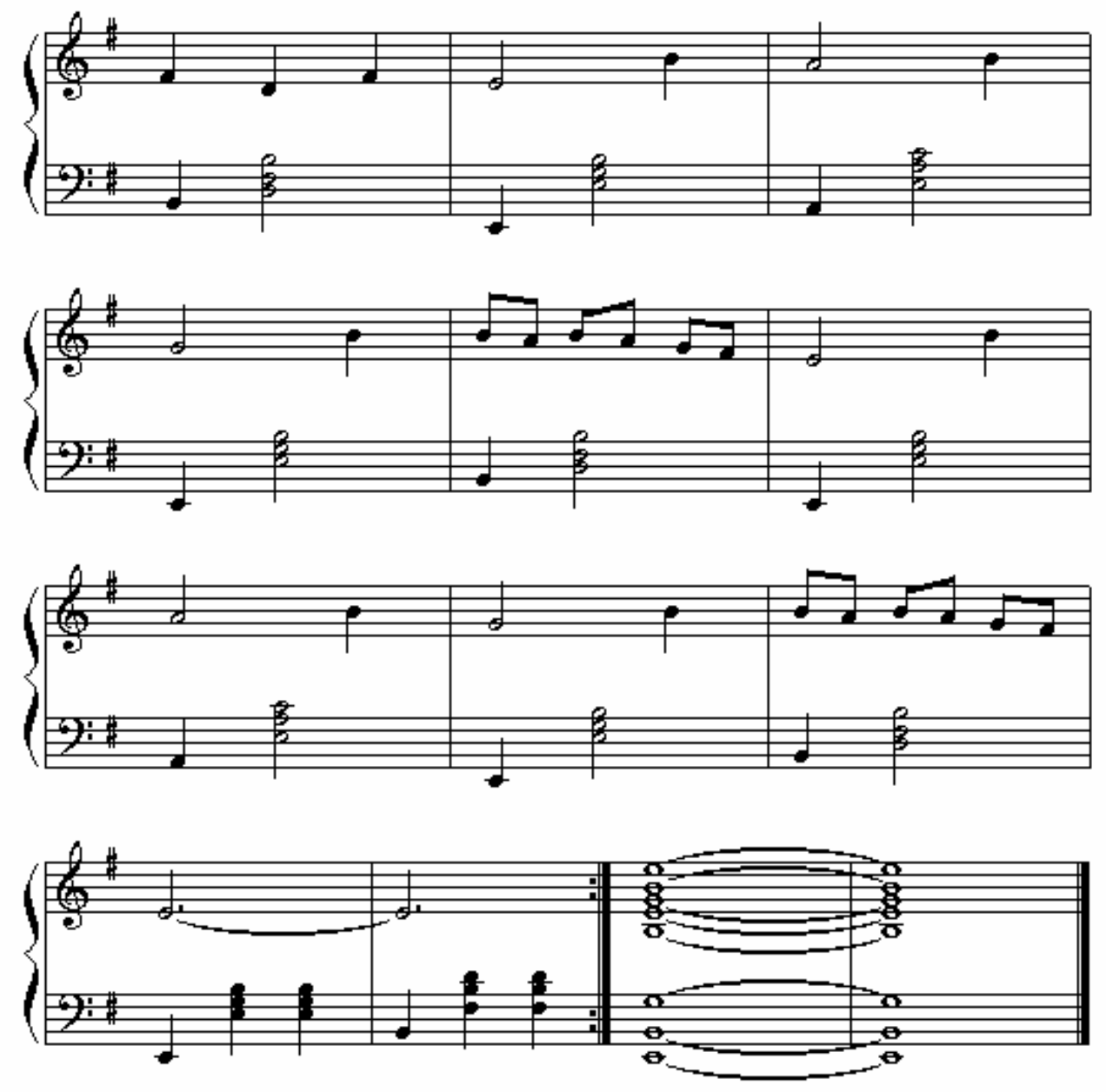
Apêndices

\section{Trecho musical 01 - Modo Frígio}
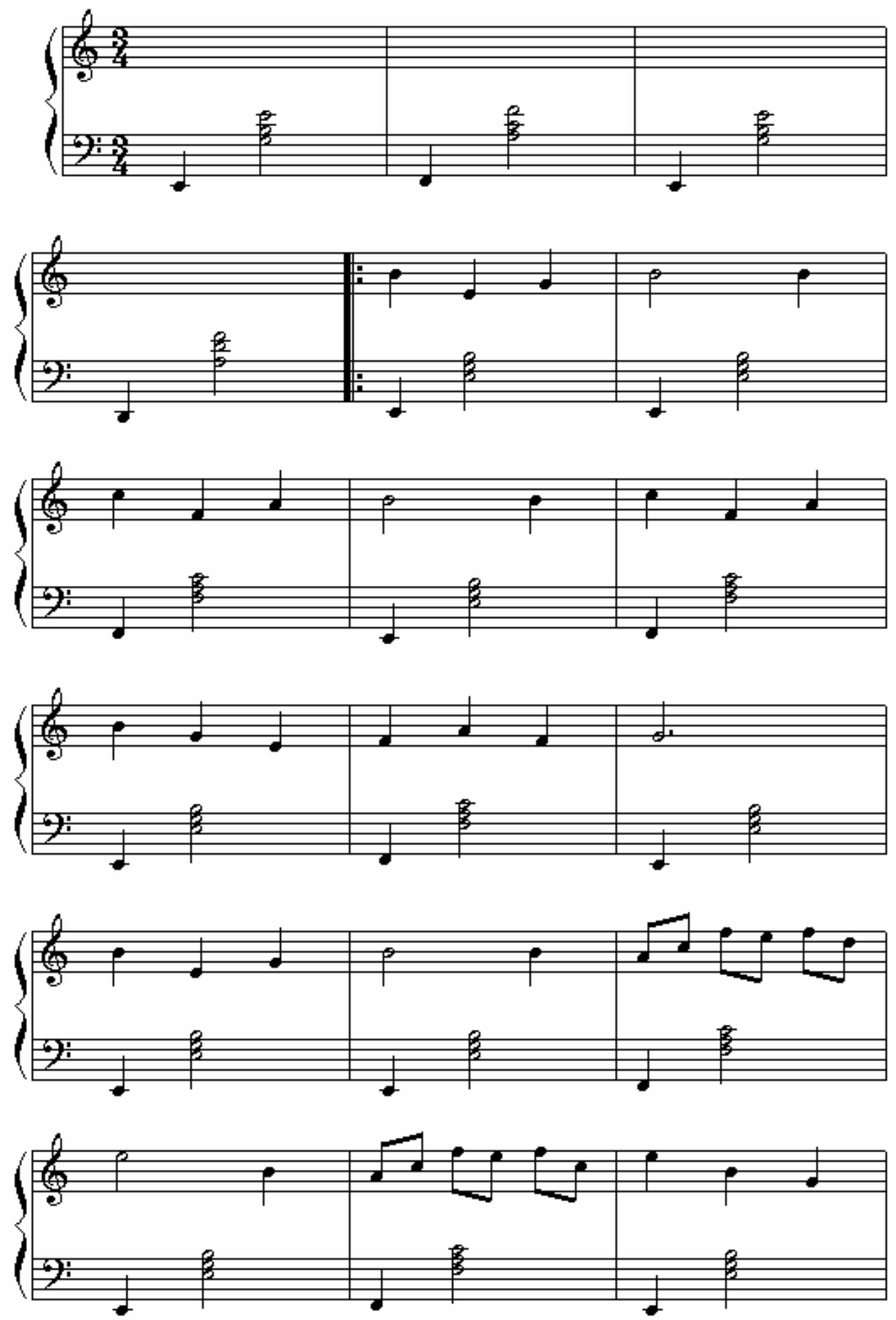

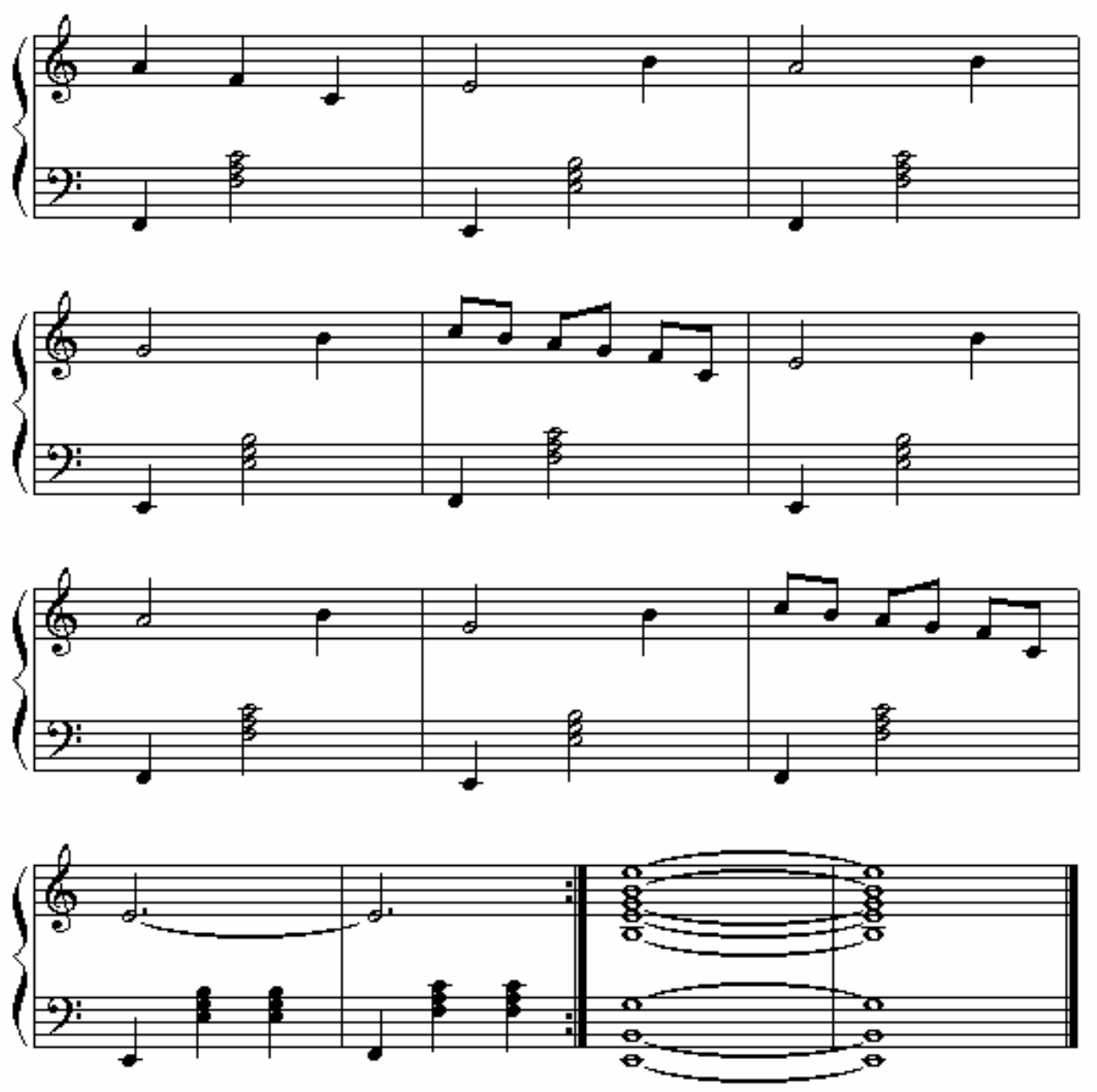
Trecho musical 01 - Modo Lócrio
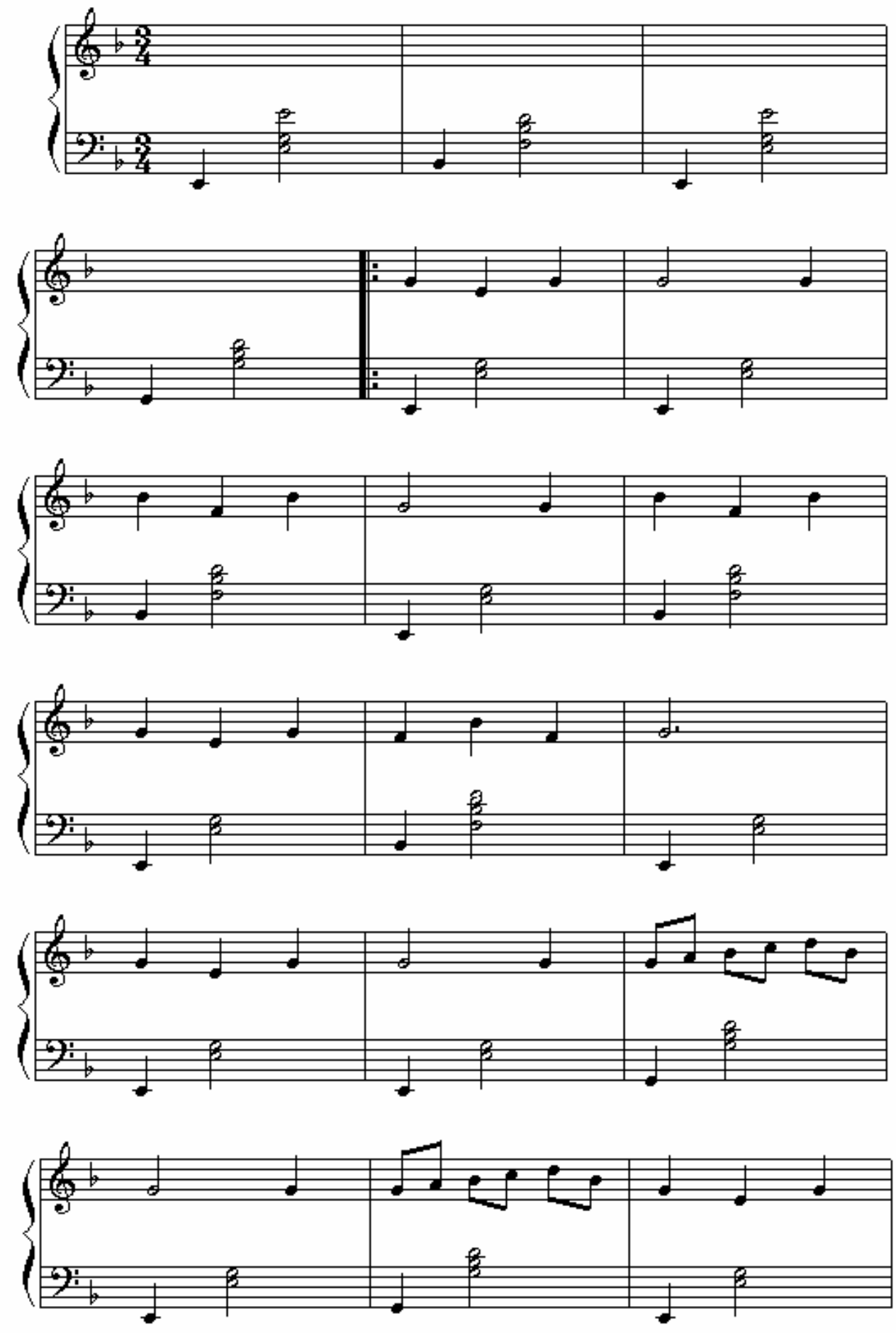

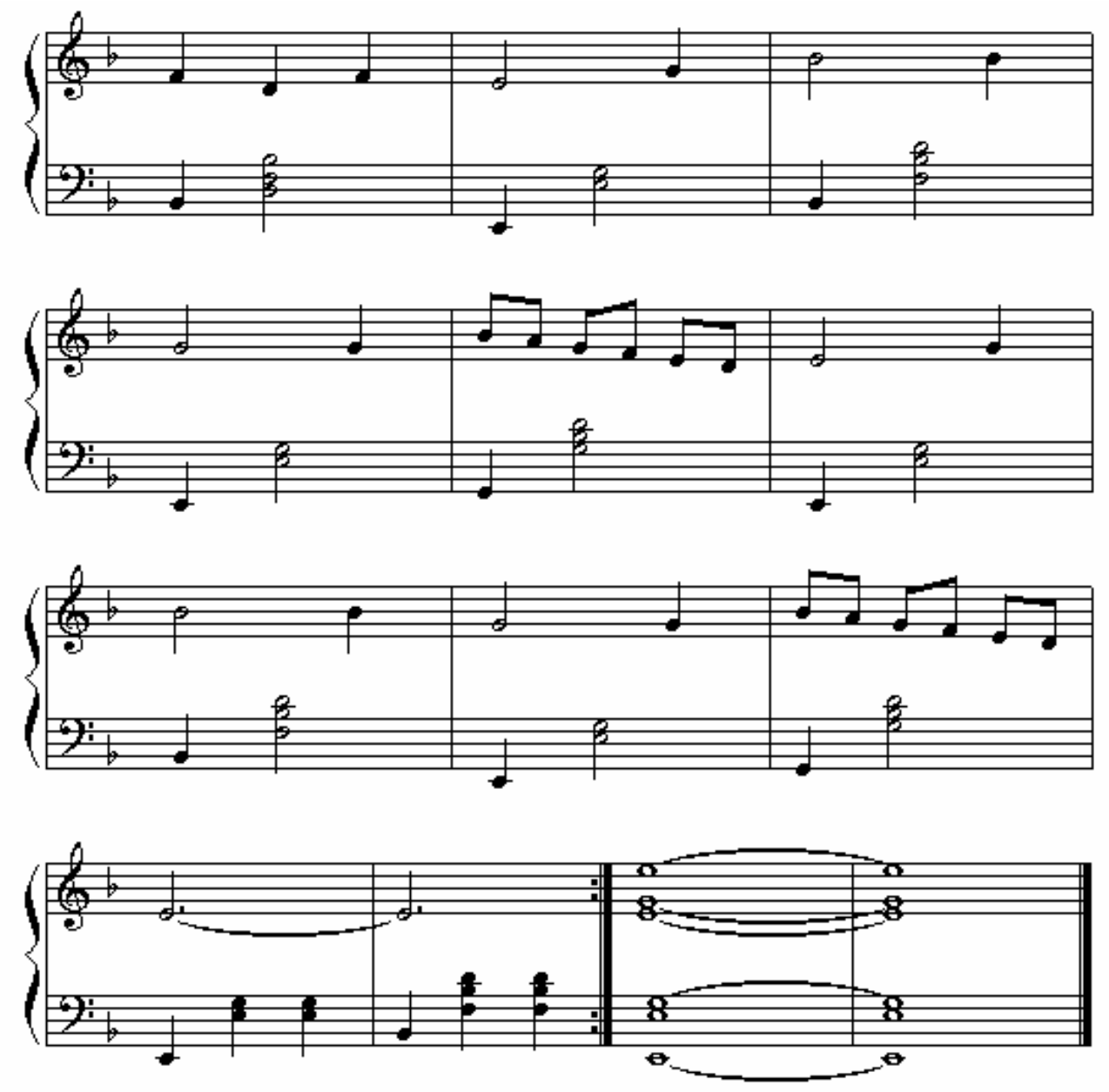


\section{Trecho musical 02 - Modo Lídio}
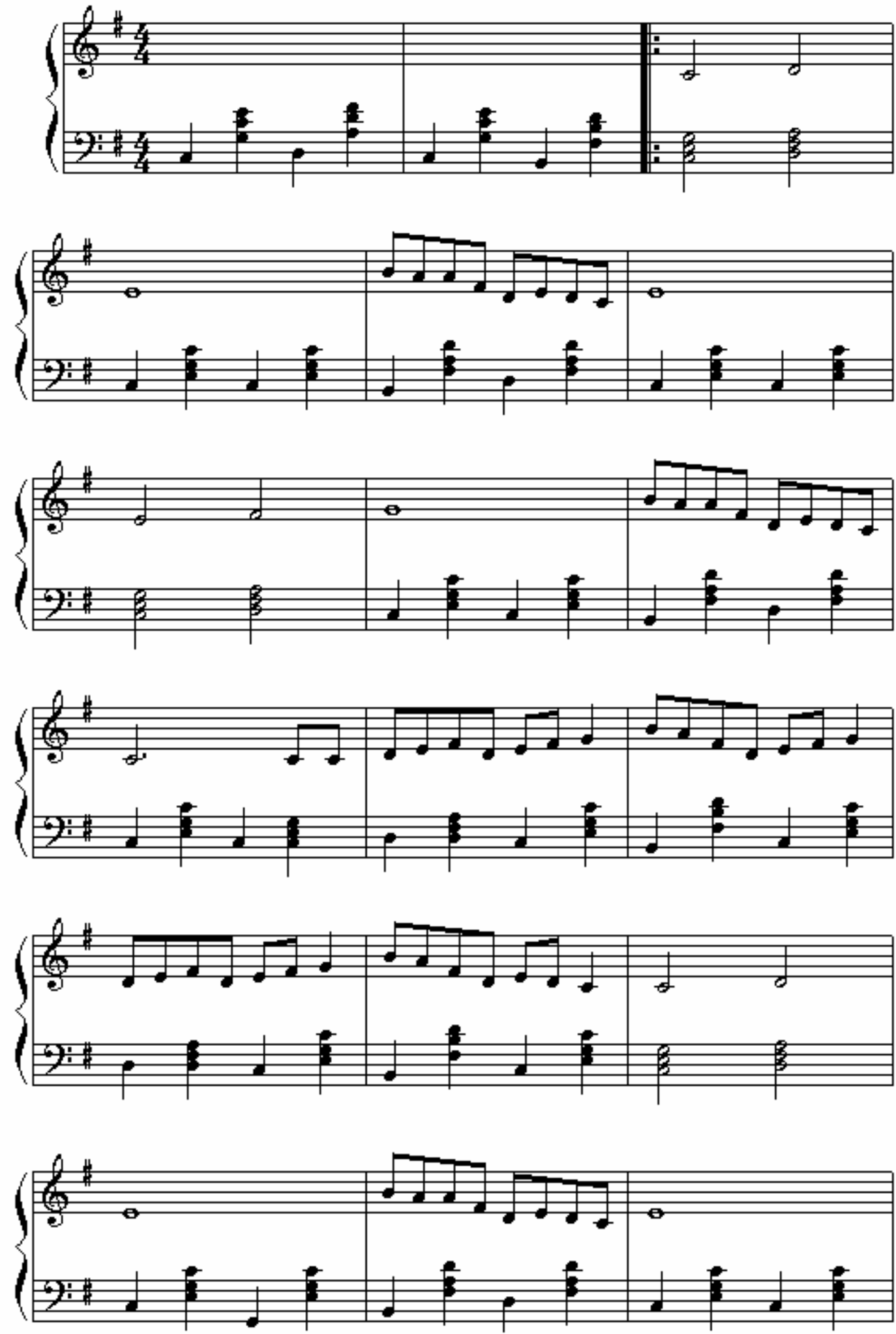

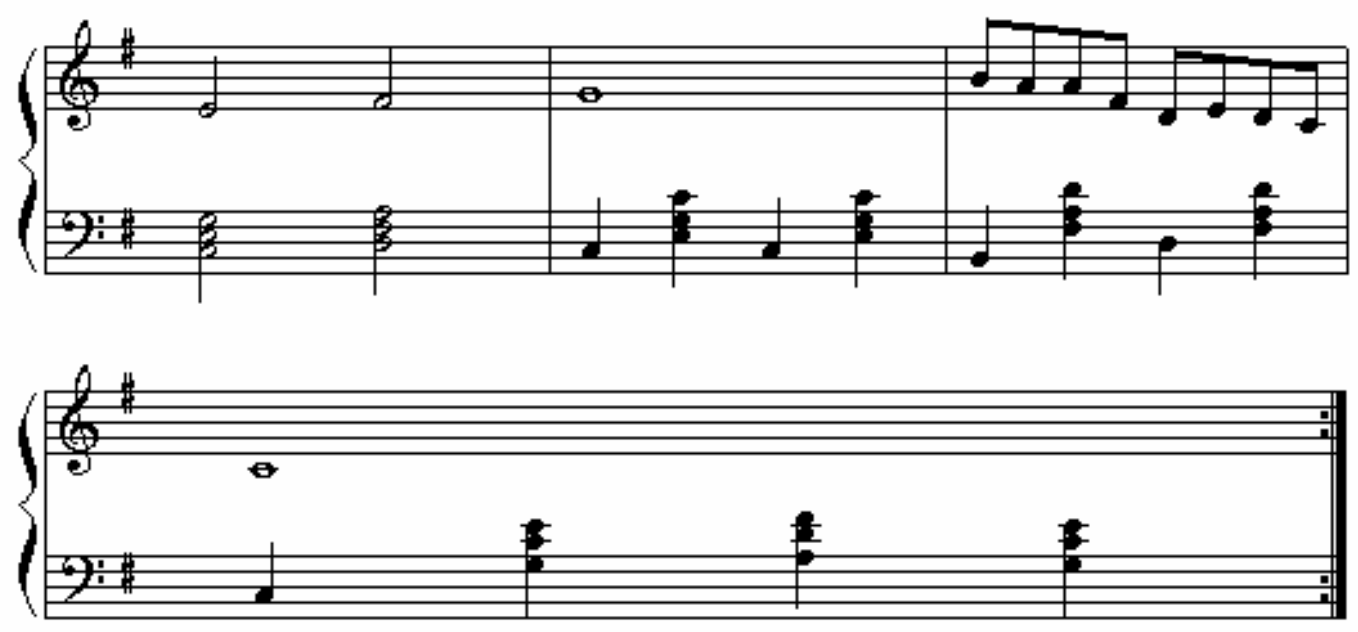
Trecho musical 02 - Modo Jônio
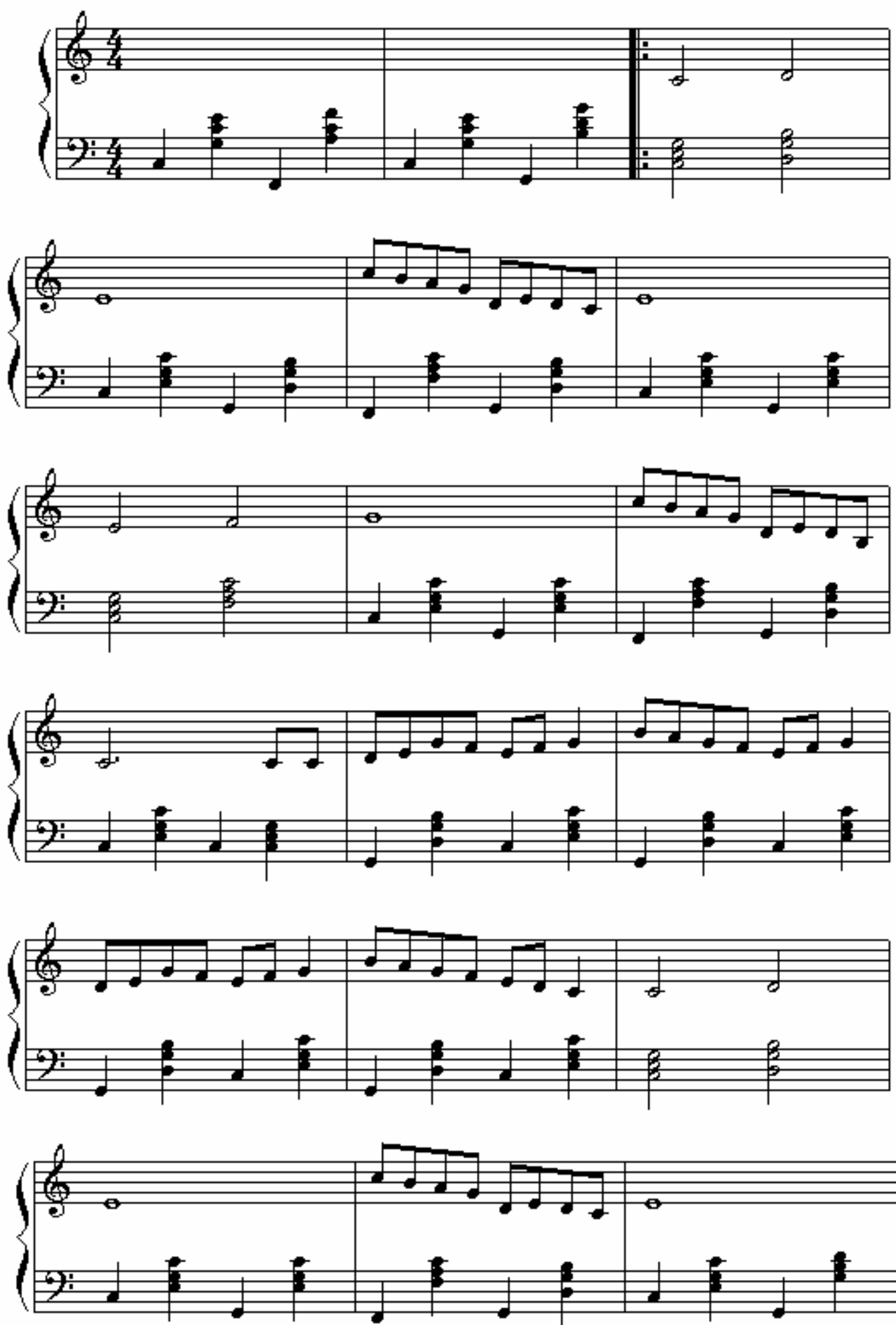

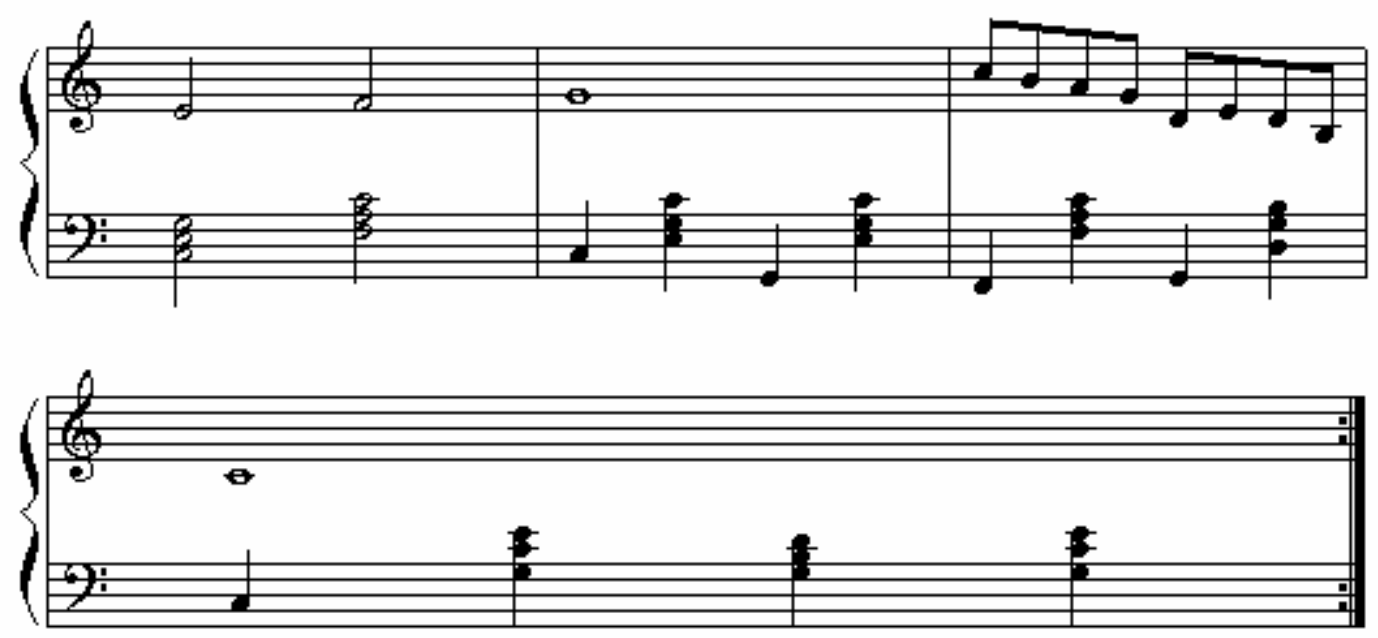
Trecho musical 02 - Modo Mixolídio
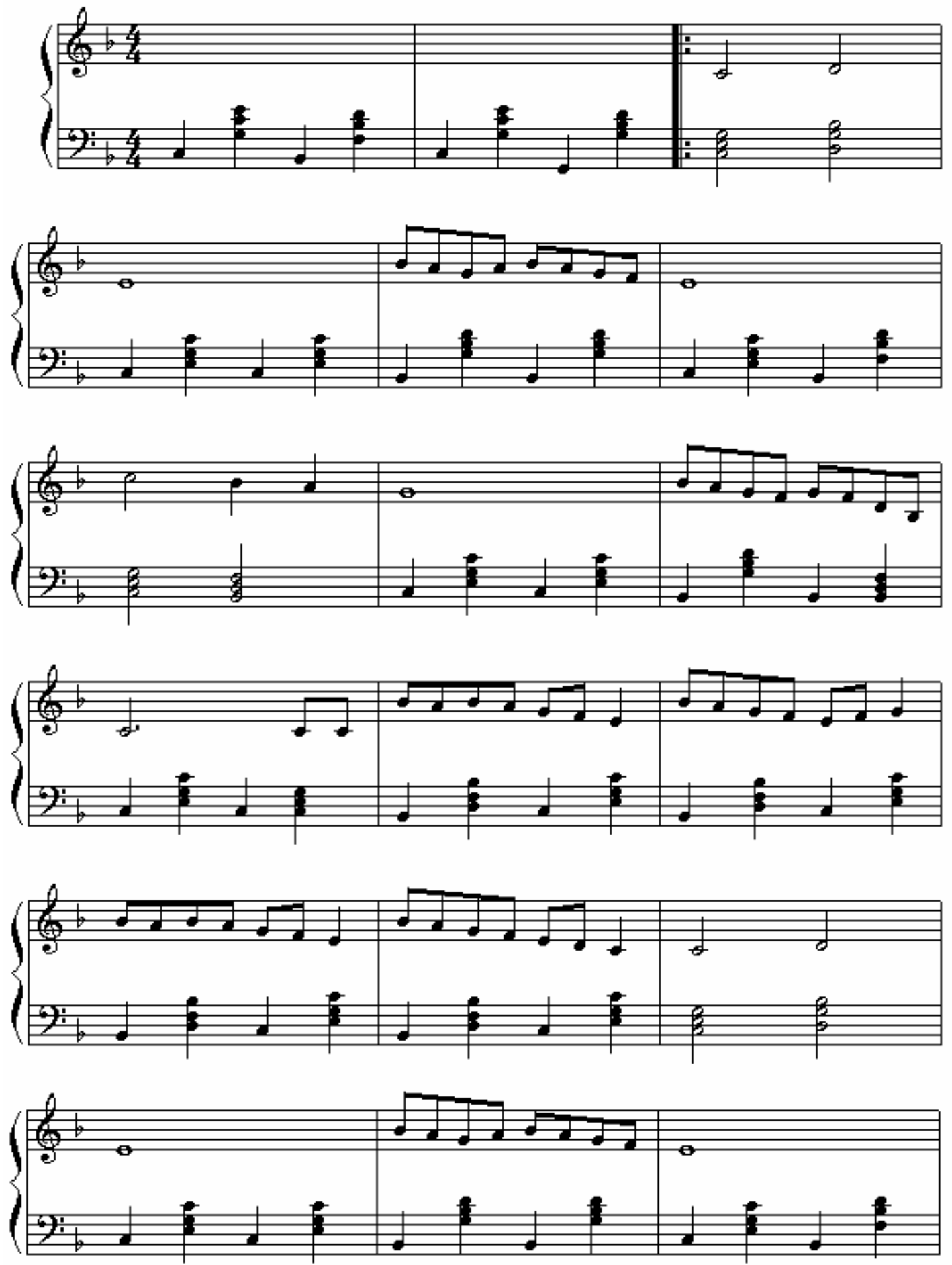

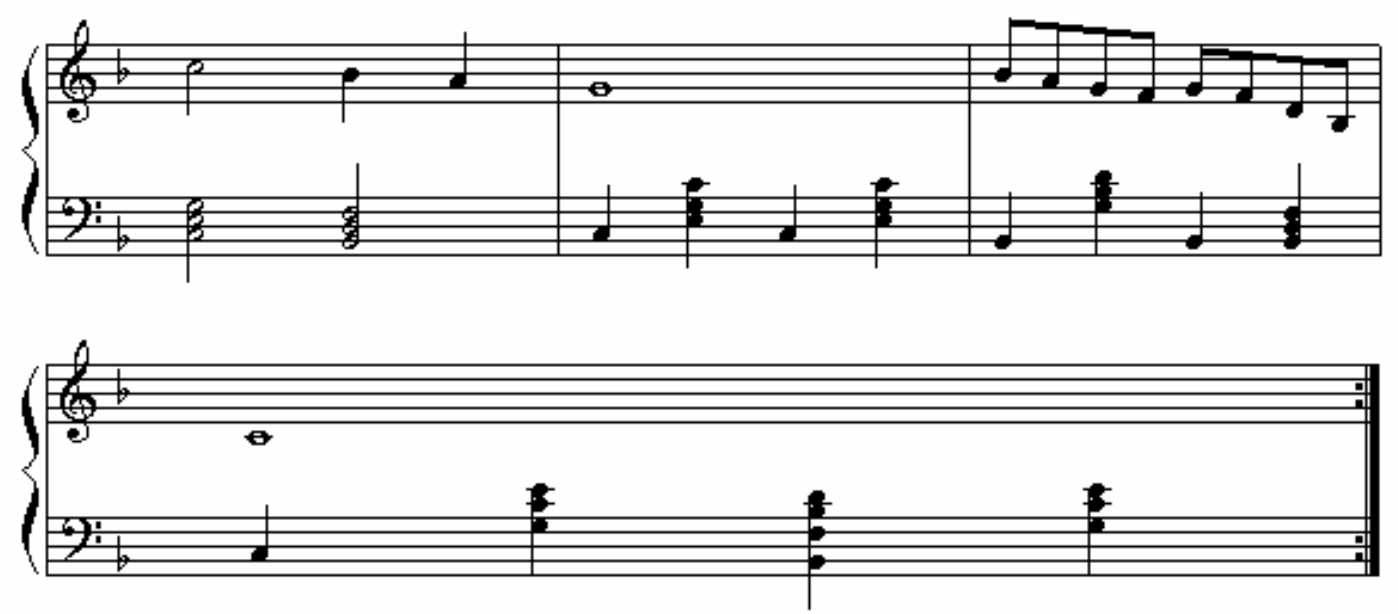


\section{Trecho musical 02 - Modo Dórico}
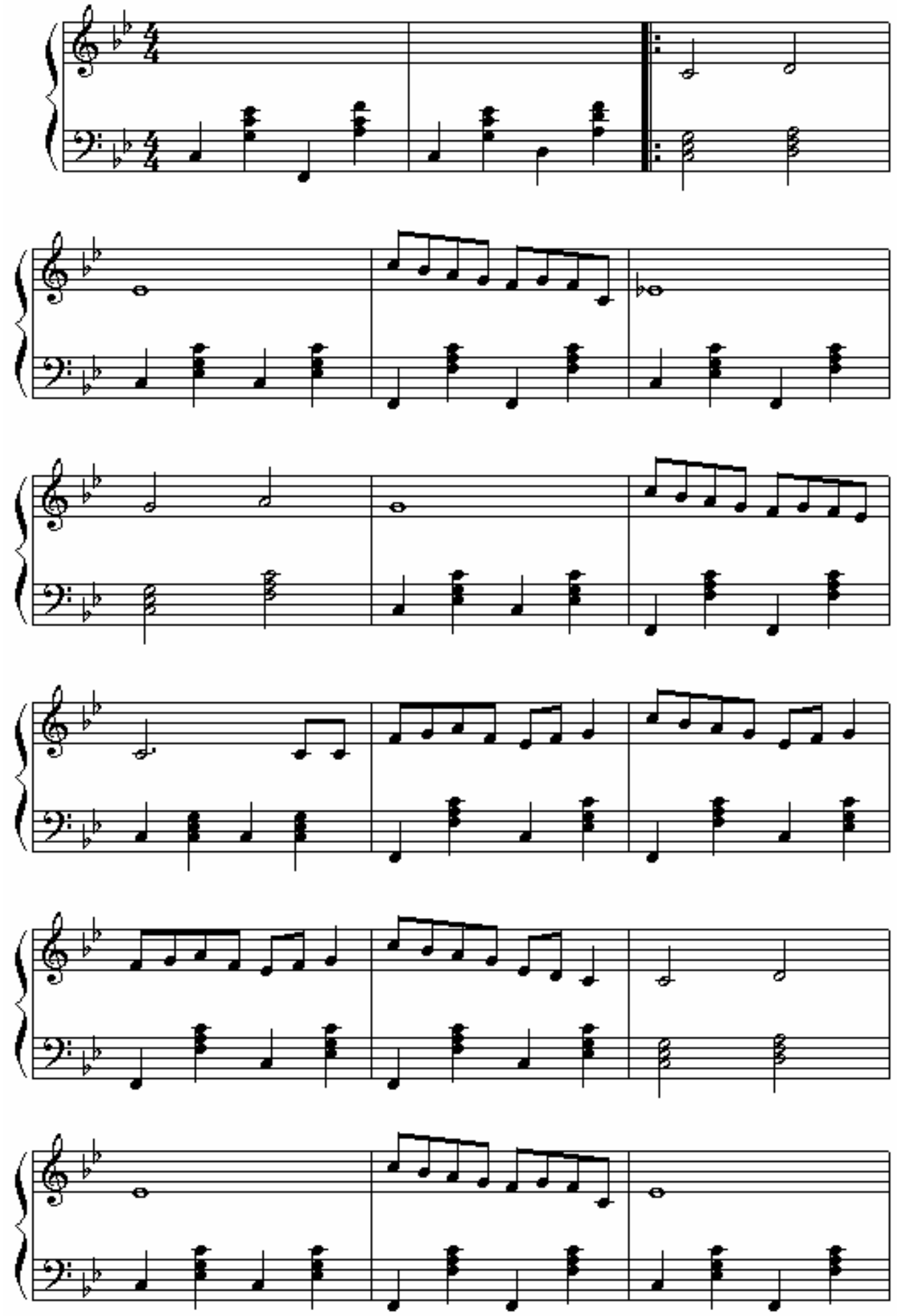

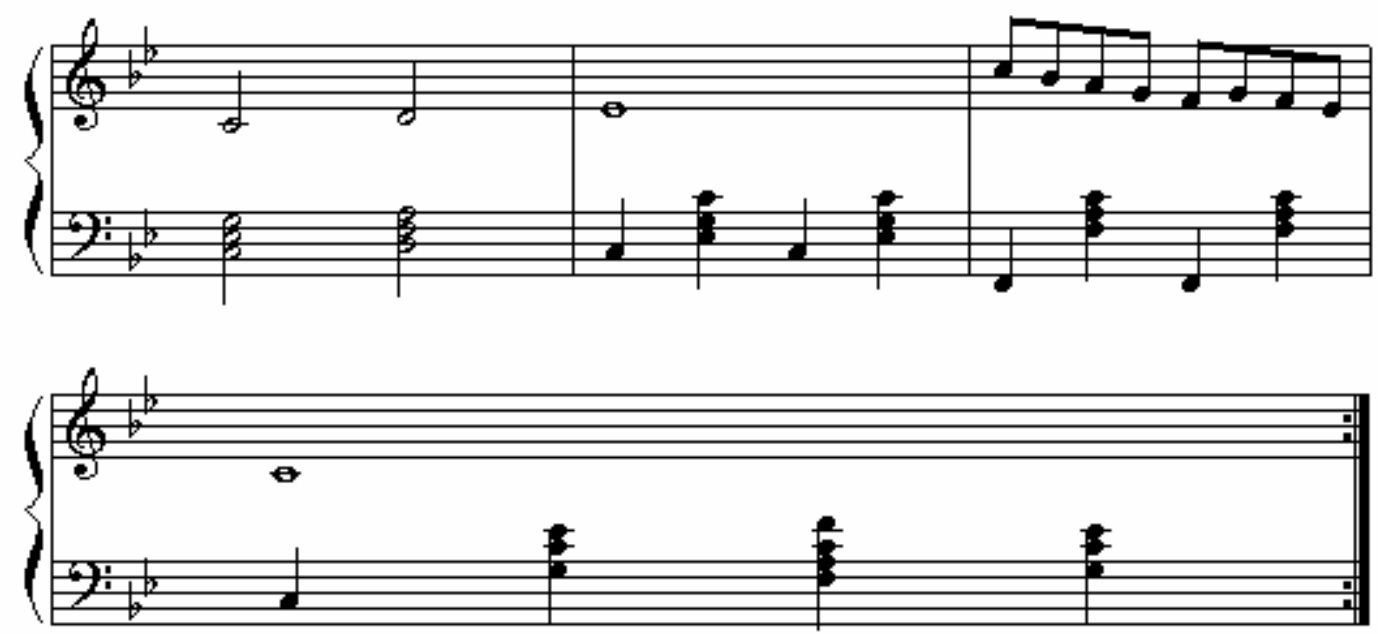


\section{Trecho musical 02 - Modo Eólio}
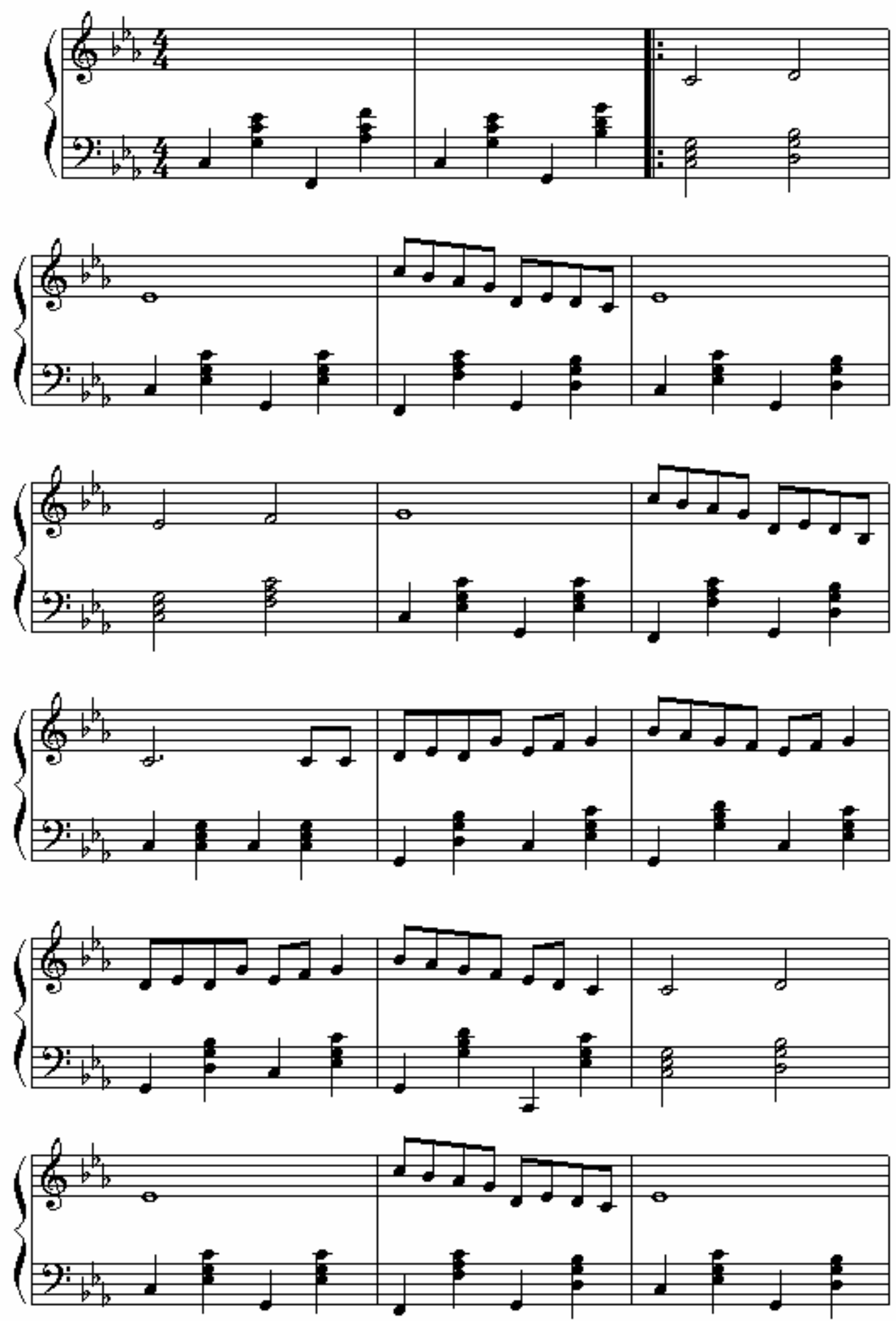

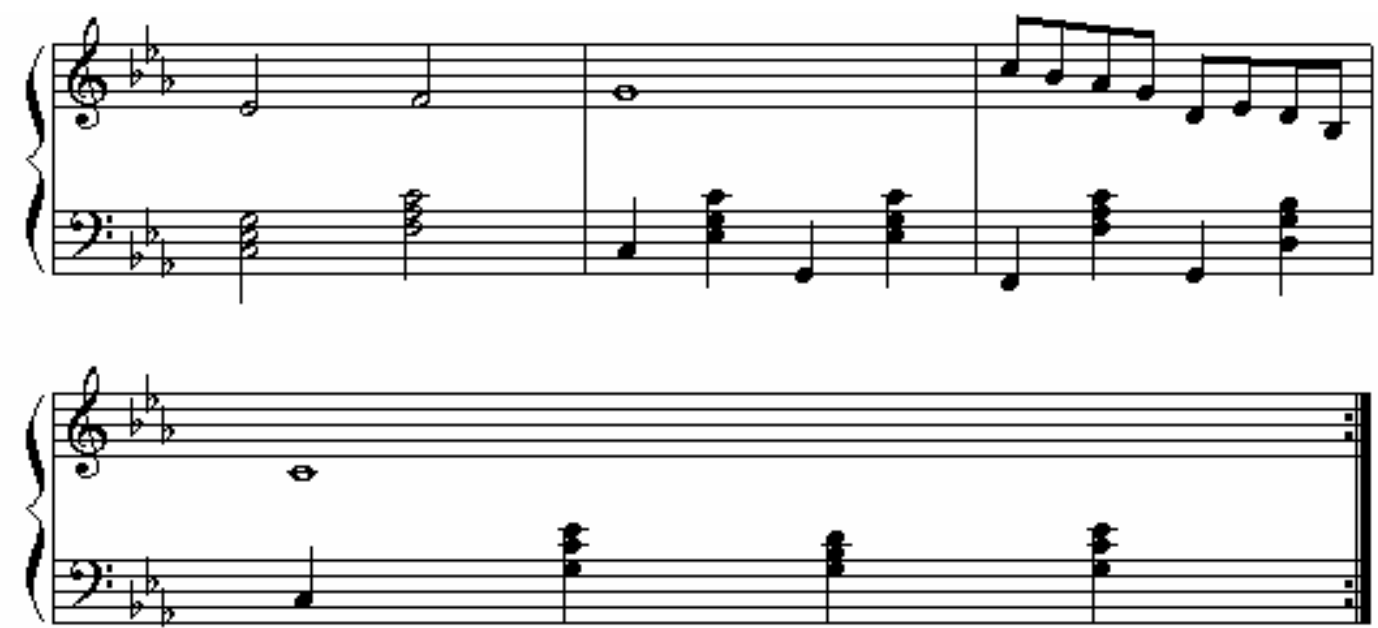
Trecho musical 02 - Modo Frígio
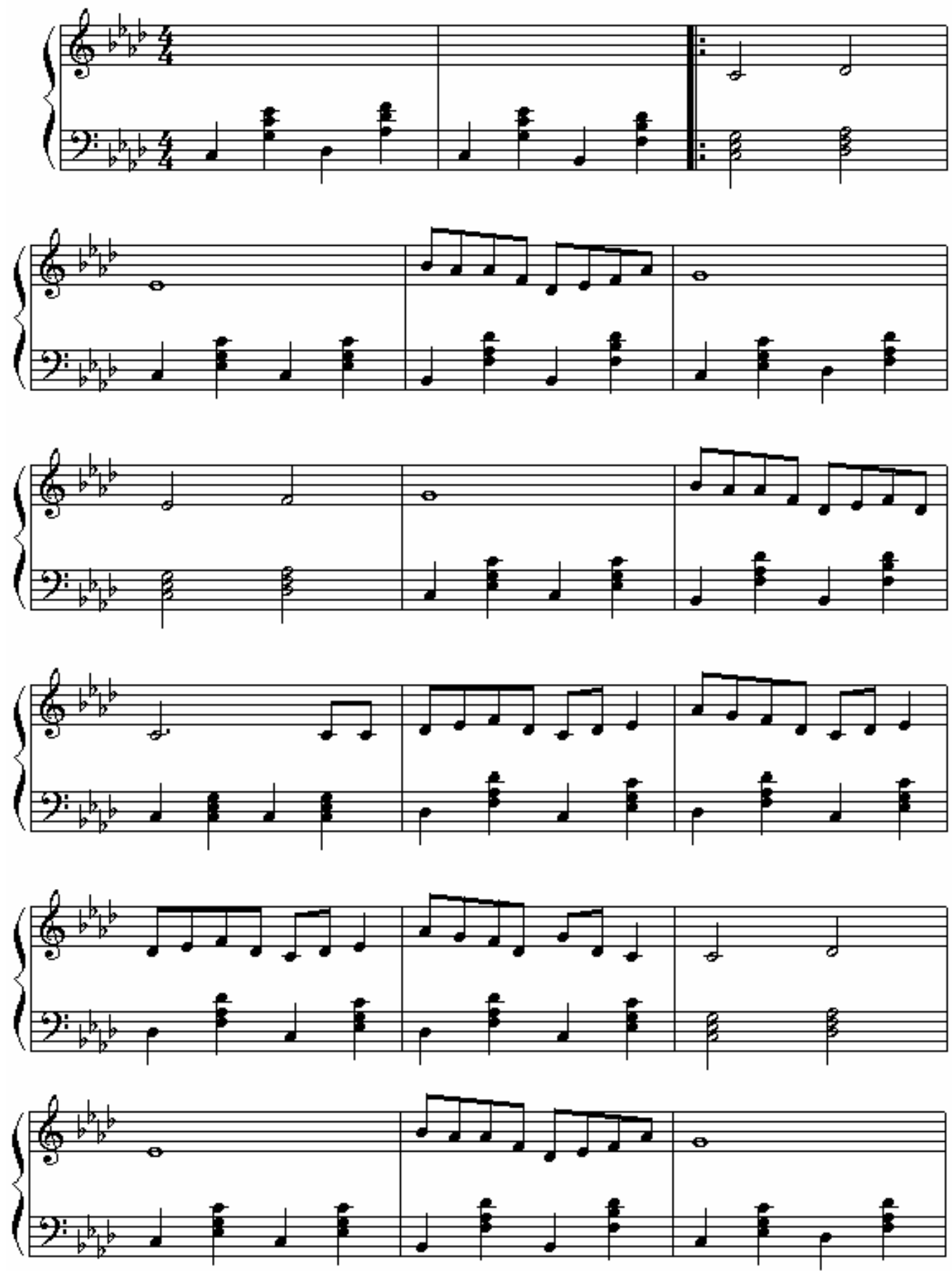

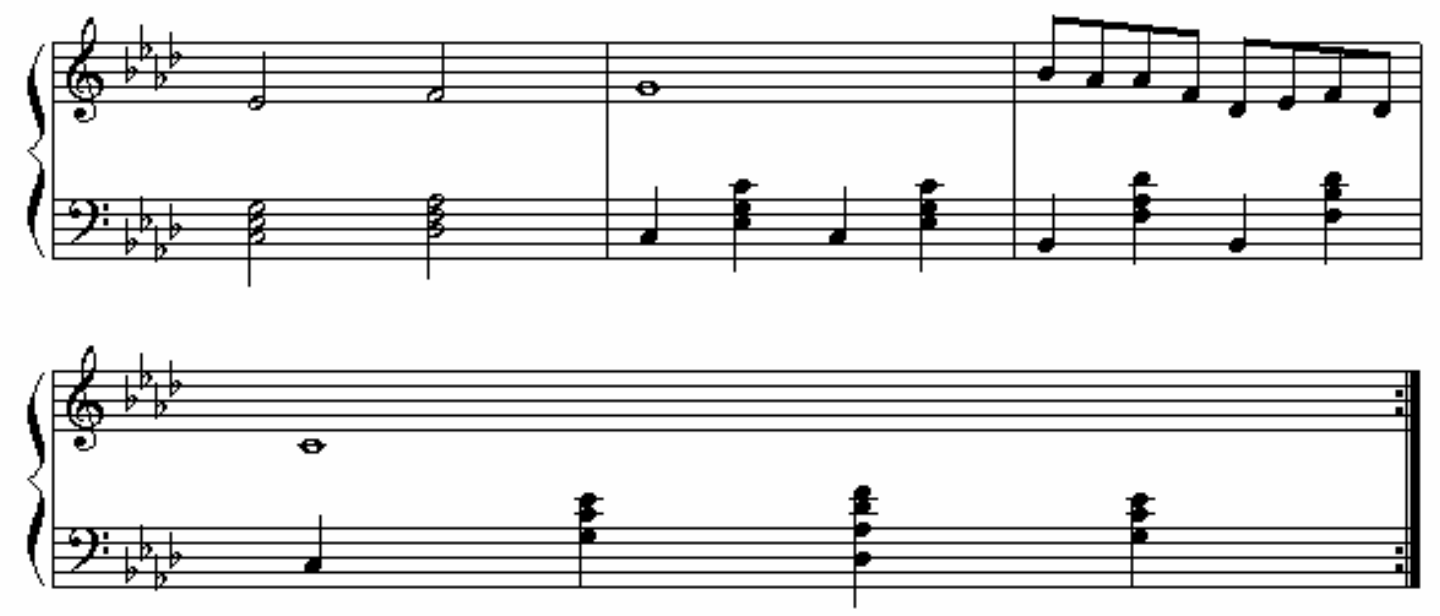
Trecho musical 02 - Modo Lócrio
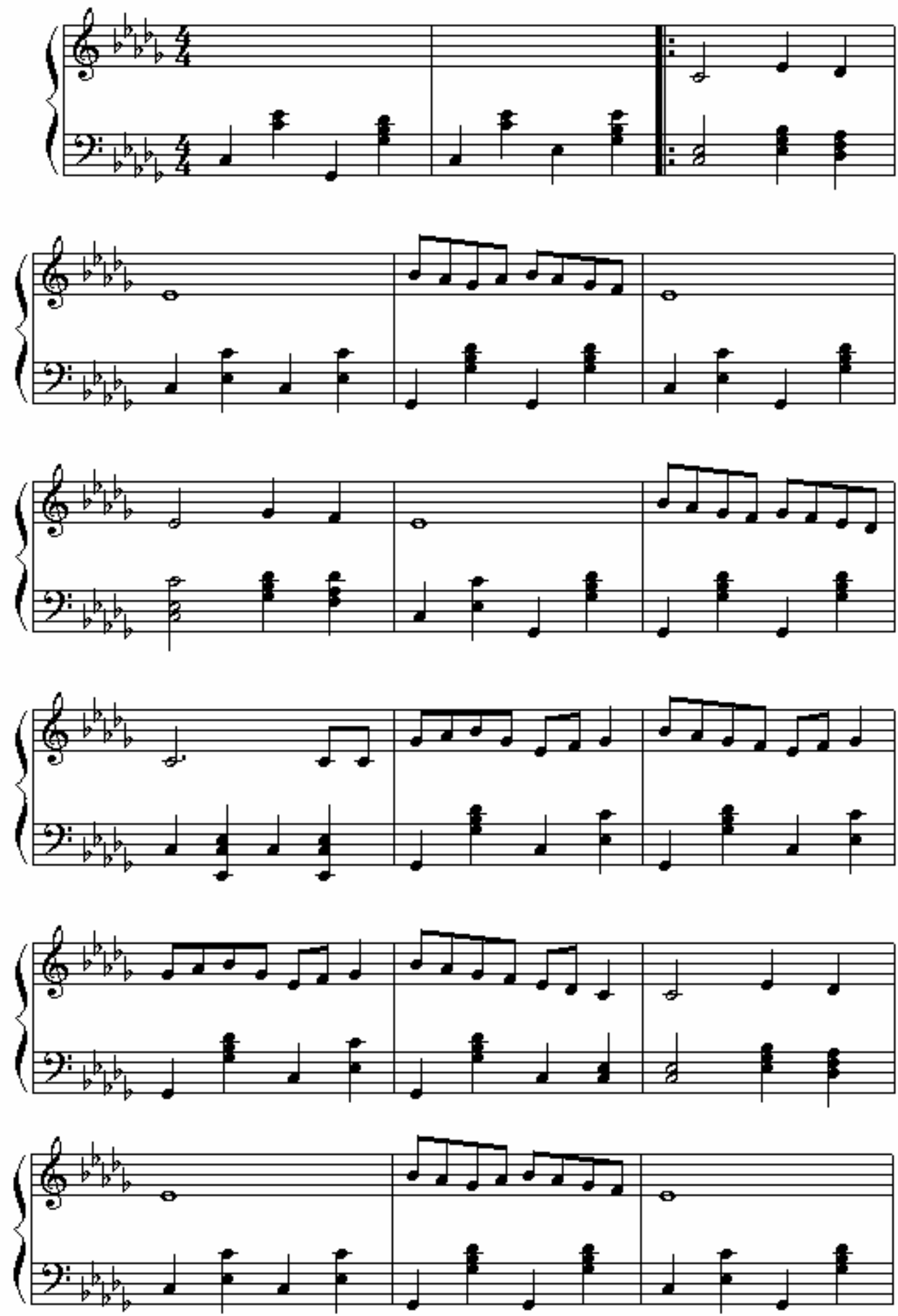

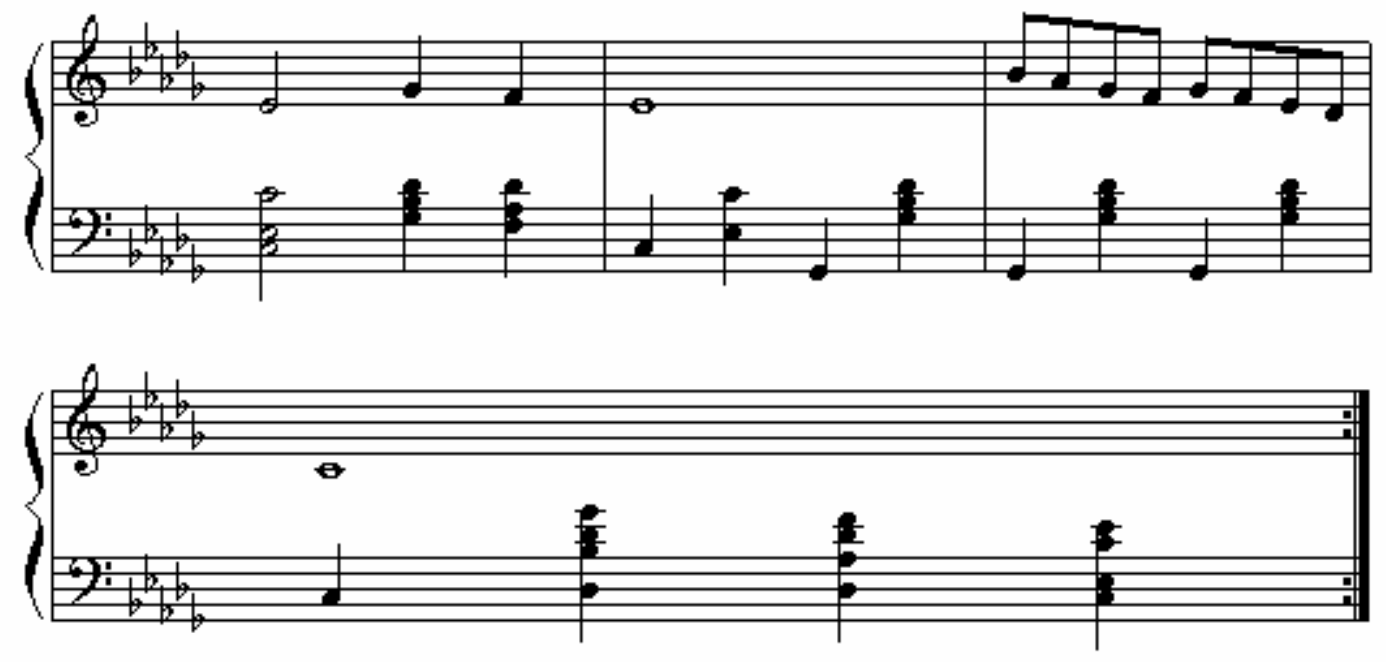


\section{Trecho musical 03 - Modo Lídio}
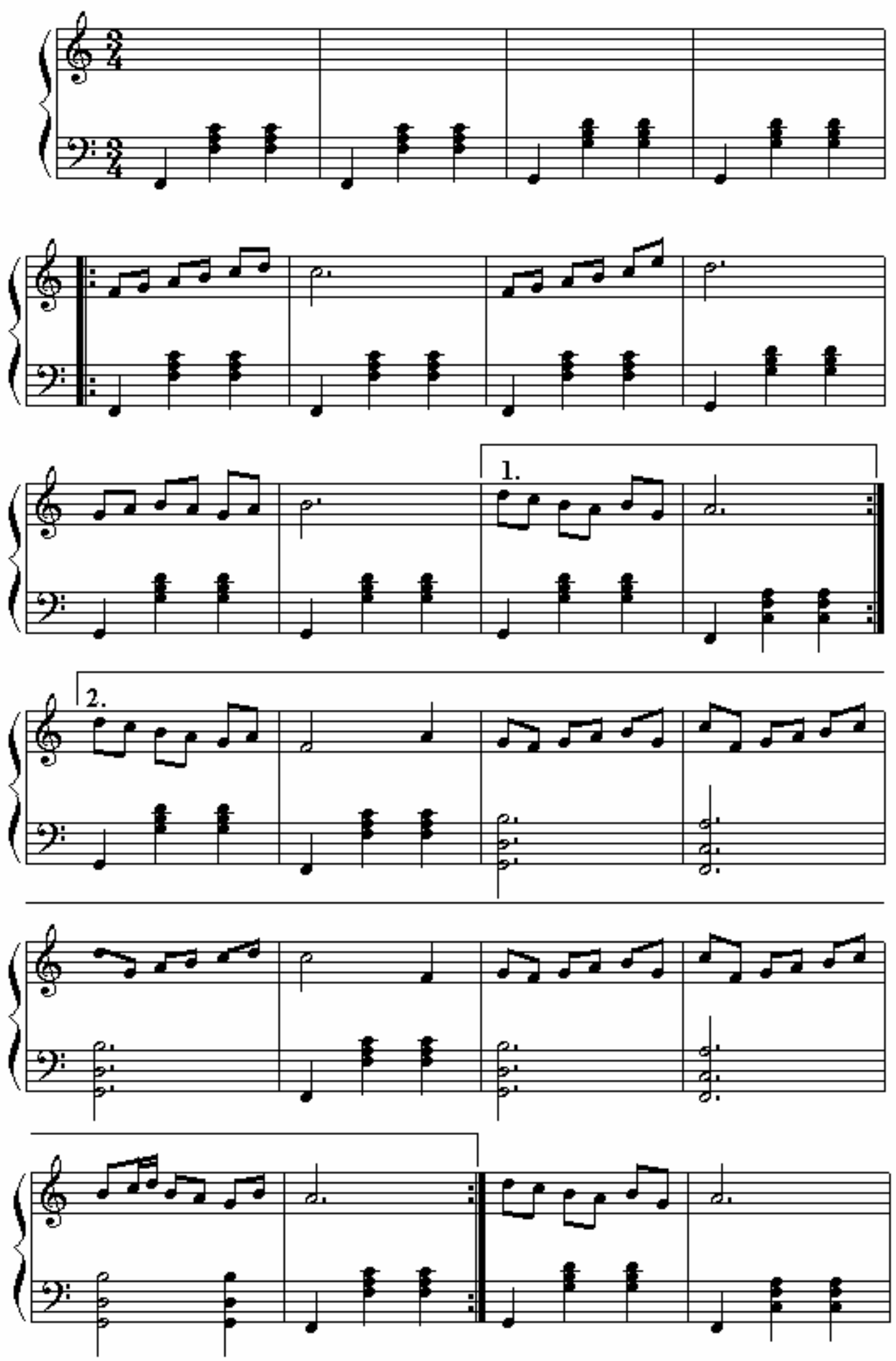

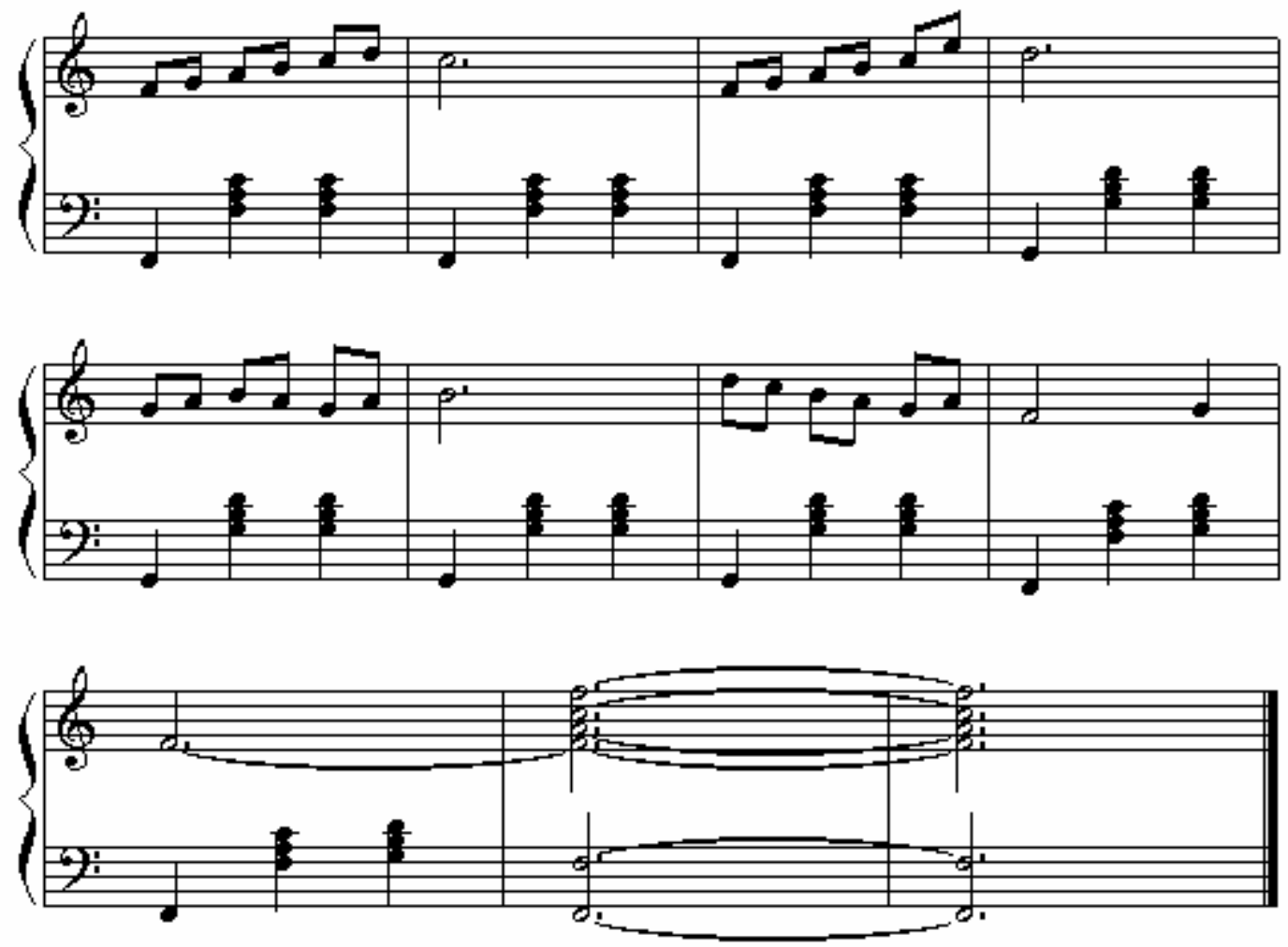


\section{Trecho musical 03 - Modo Jônio}
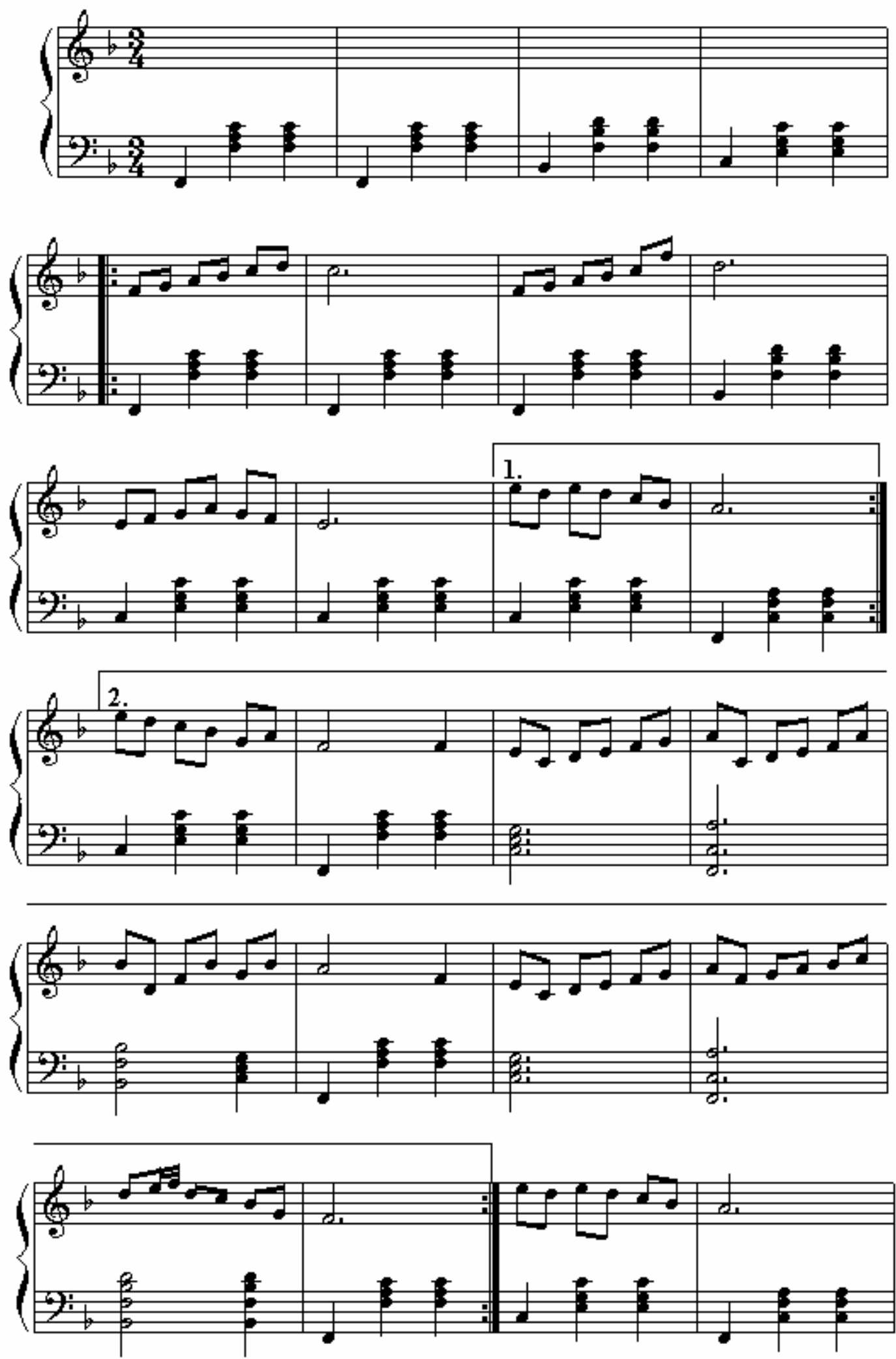

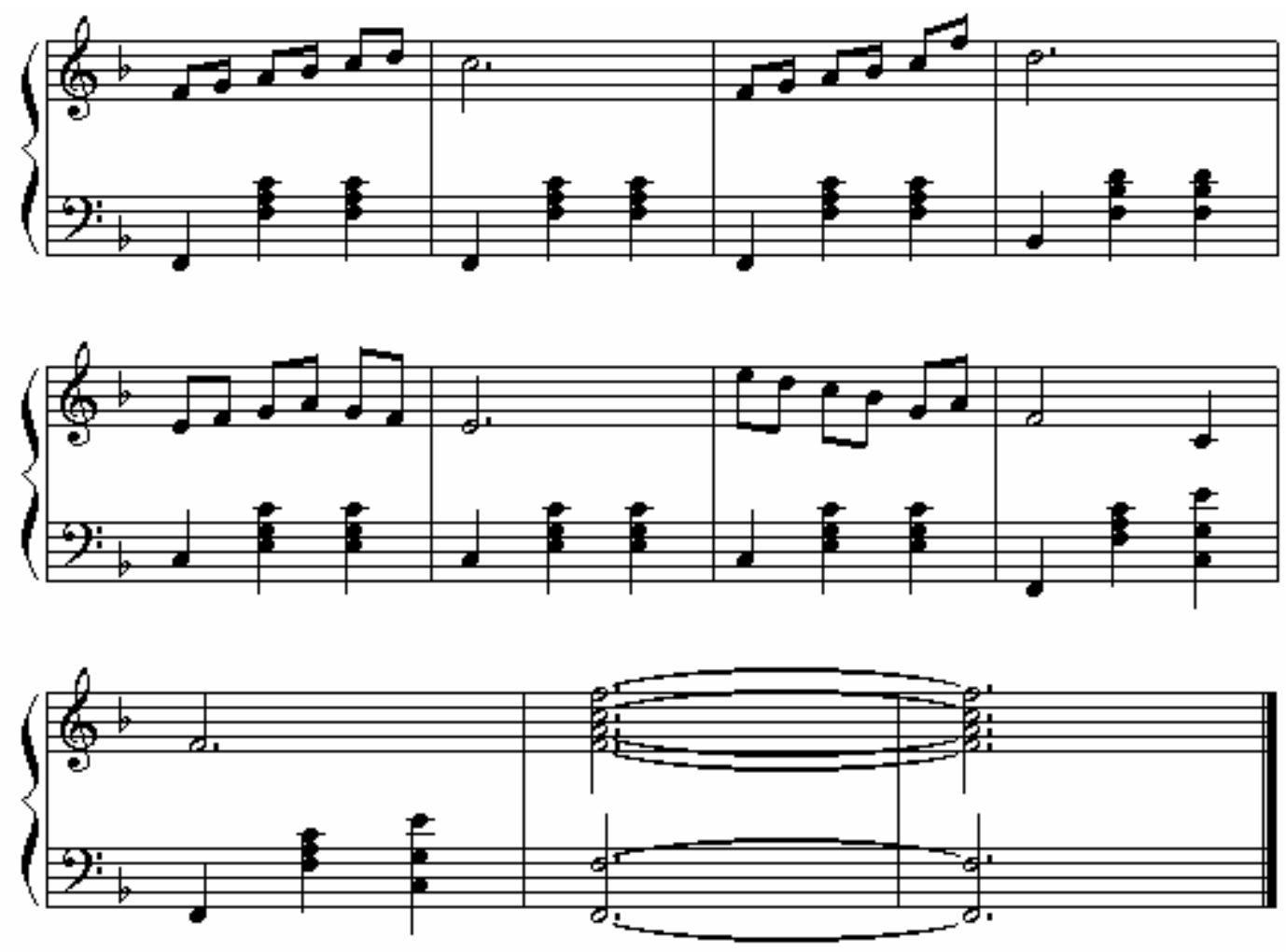
Trecho musical 03 - Modo Mixolídio
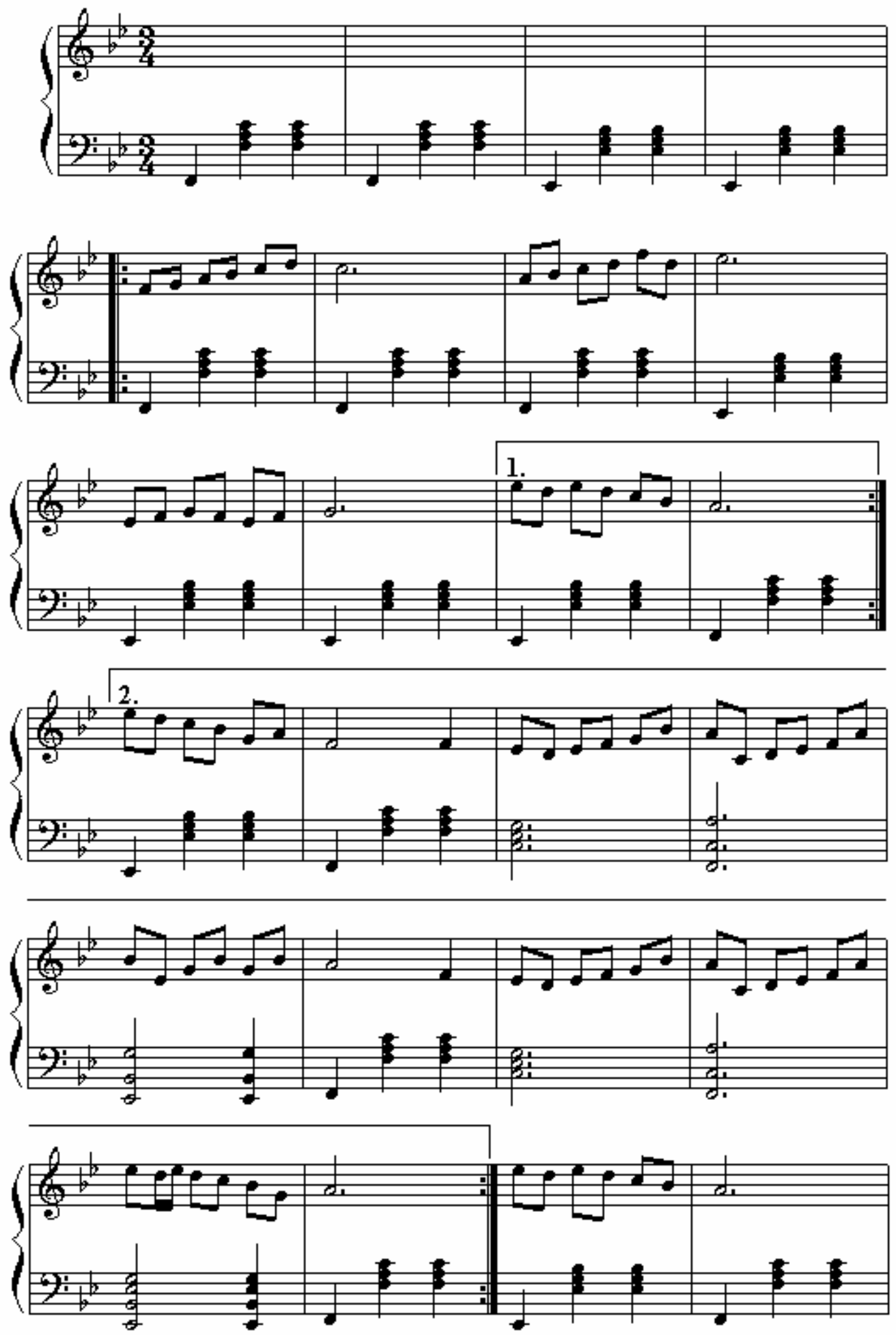

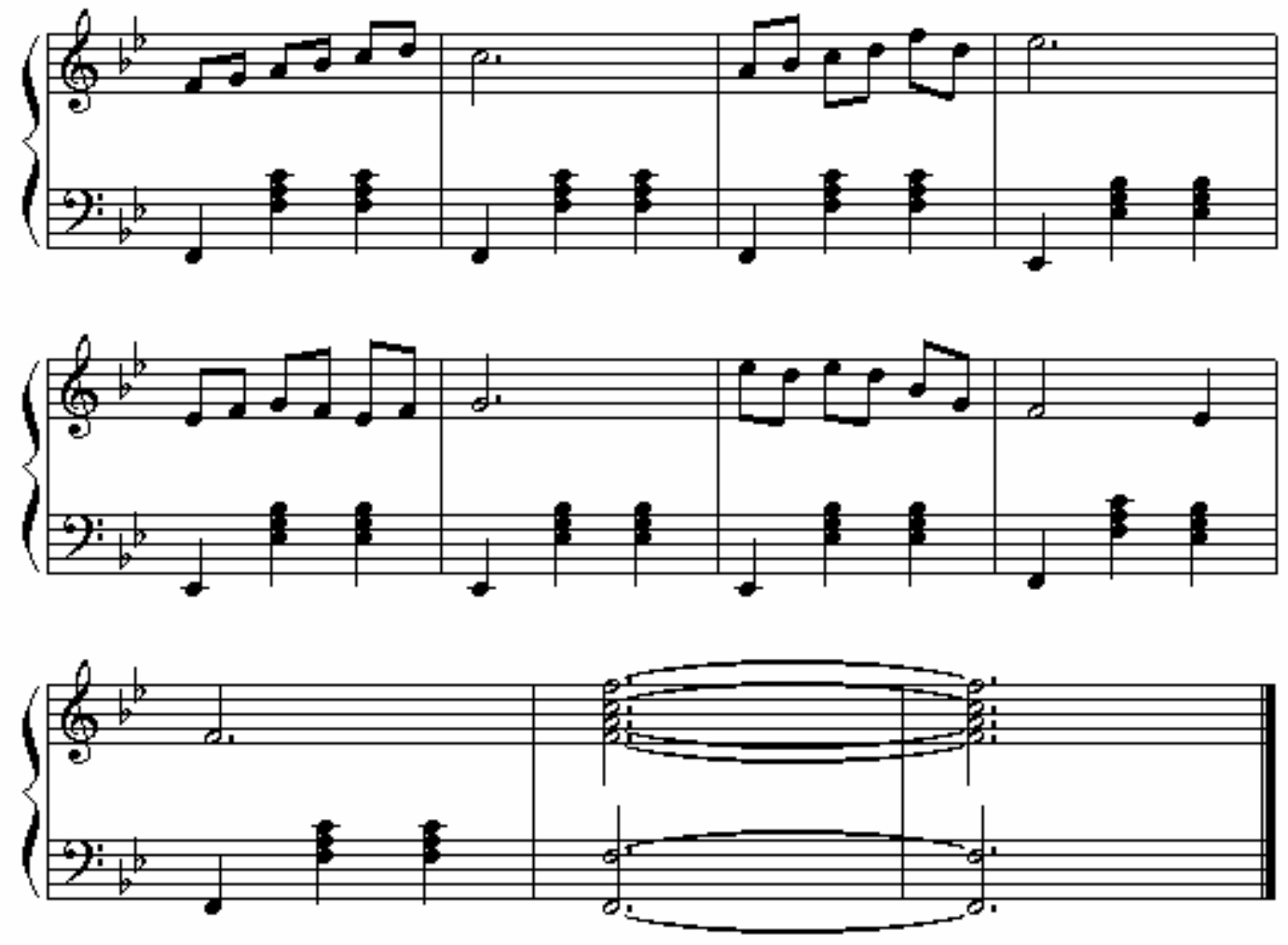
Trecho musical 03 - Modo Dórico
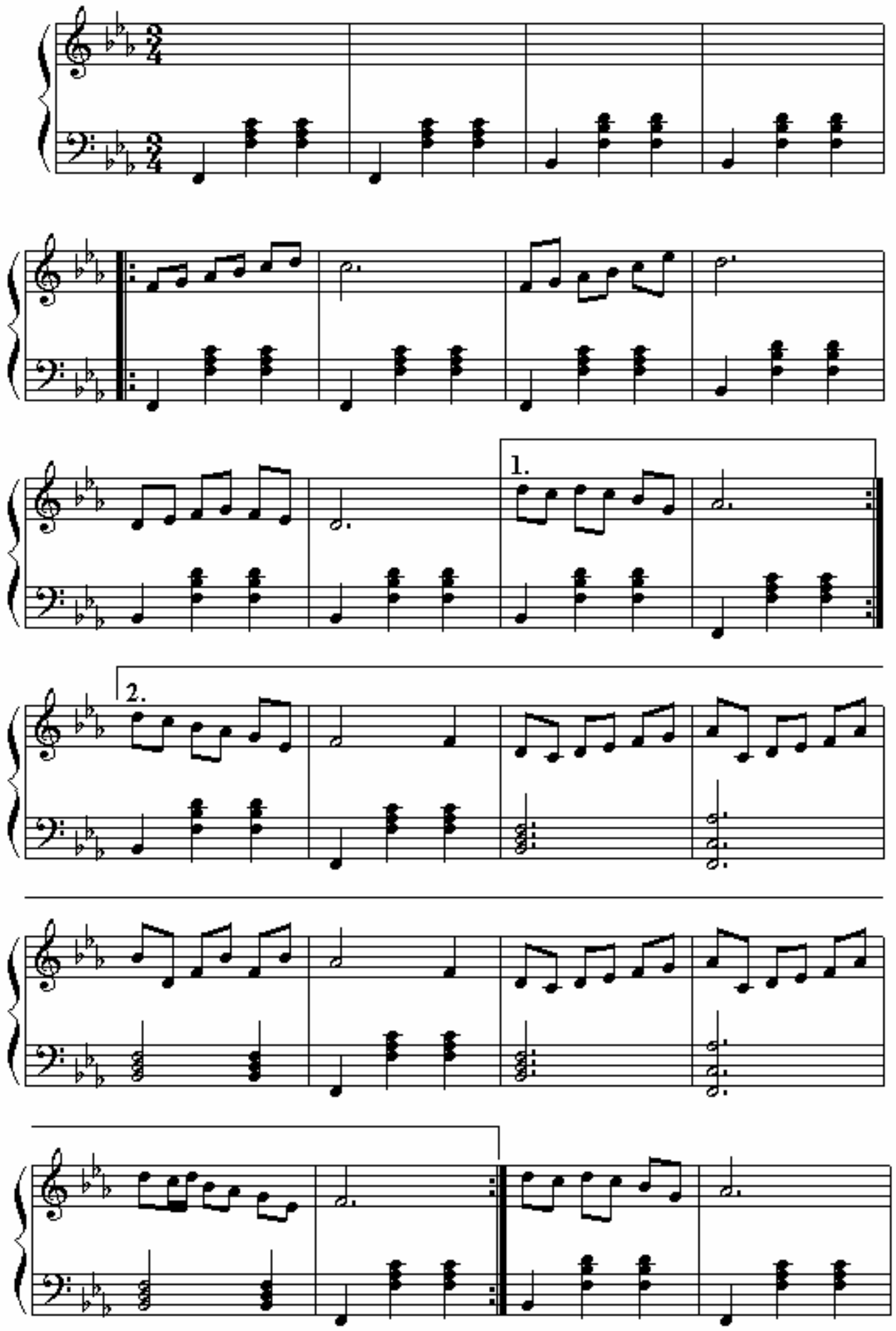

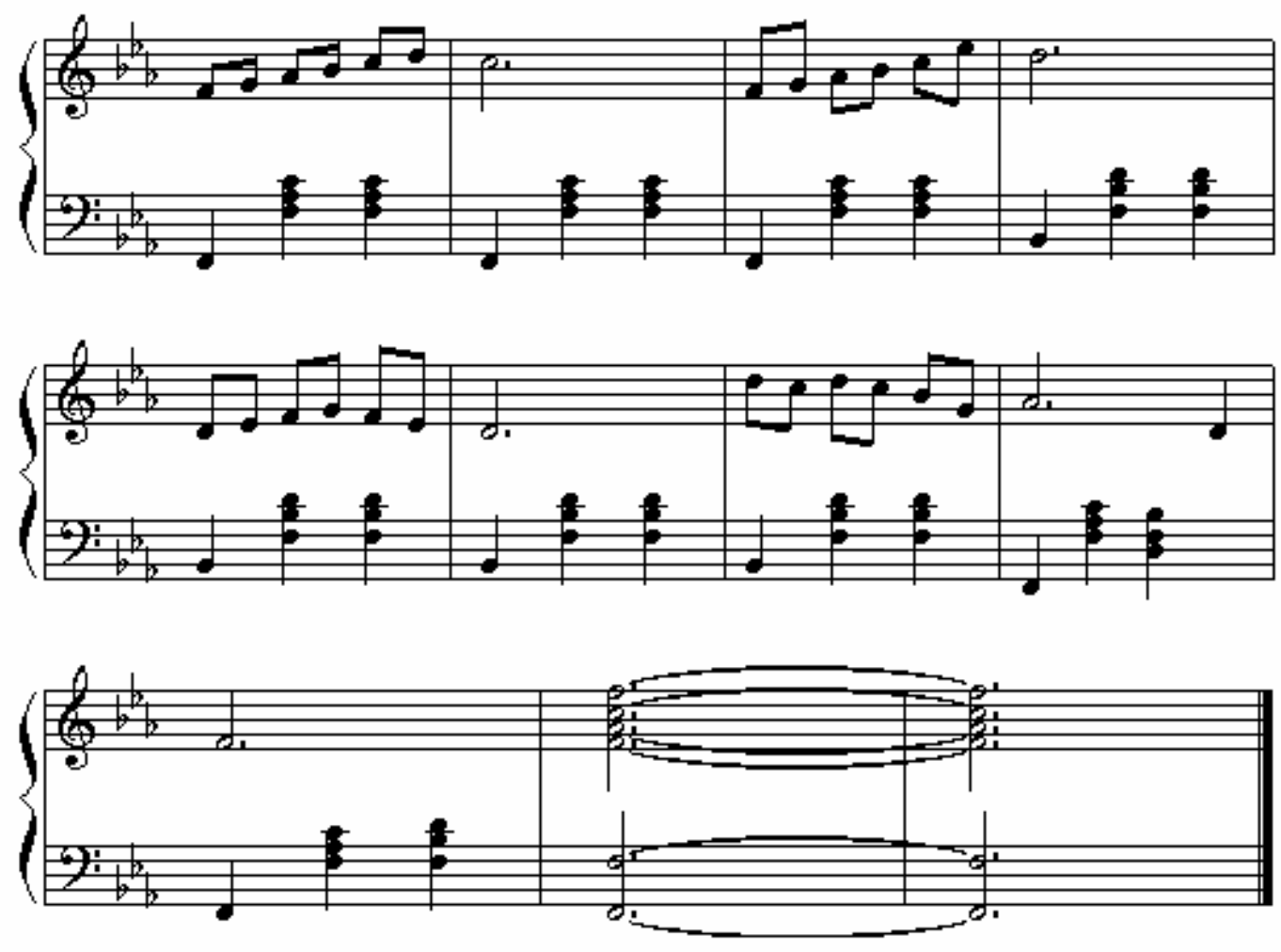


\section{Trecho musical 03 - Modo Eólio}
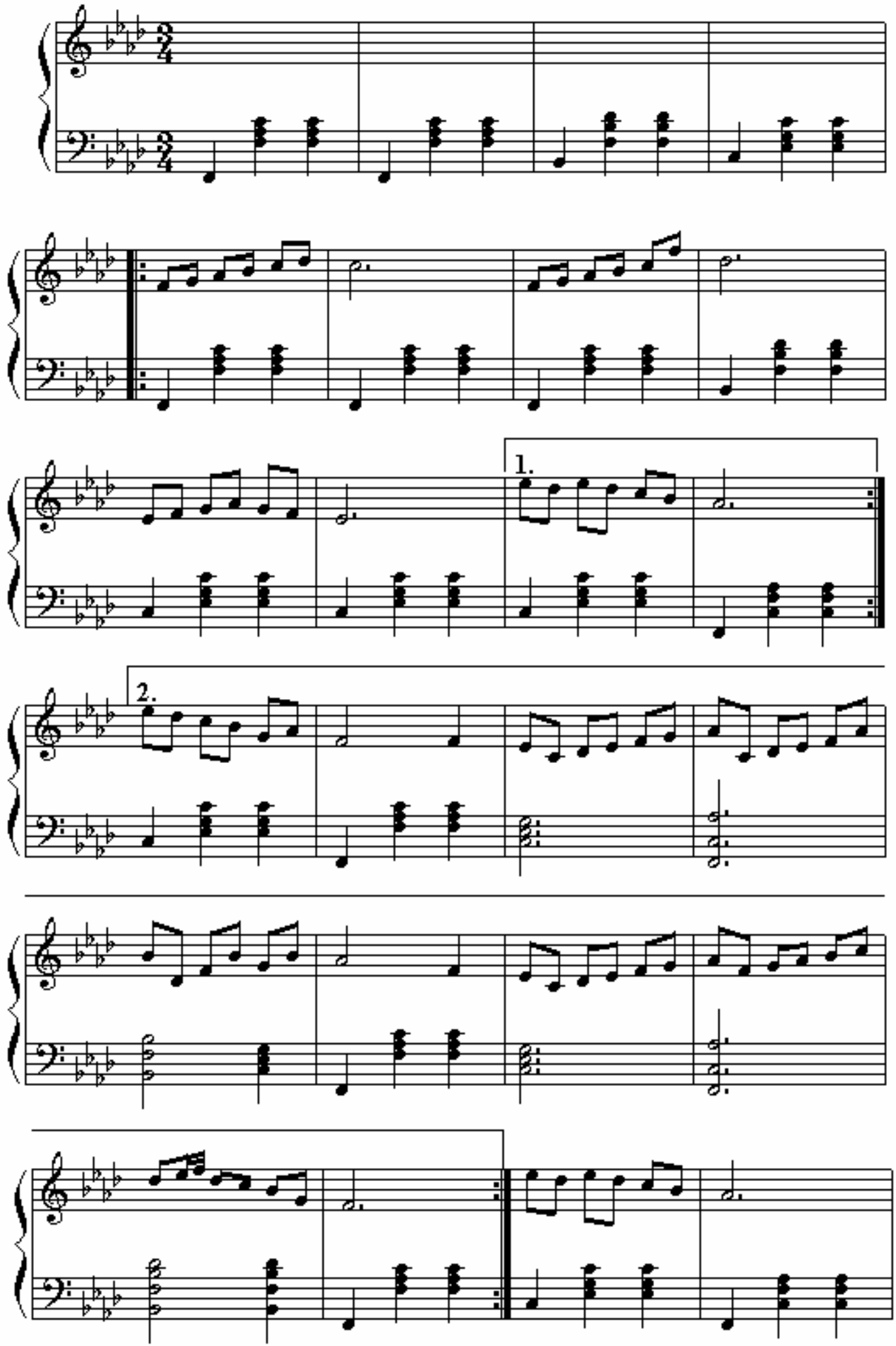

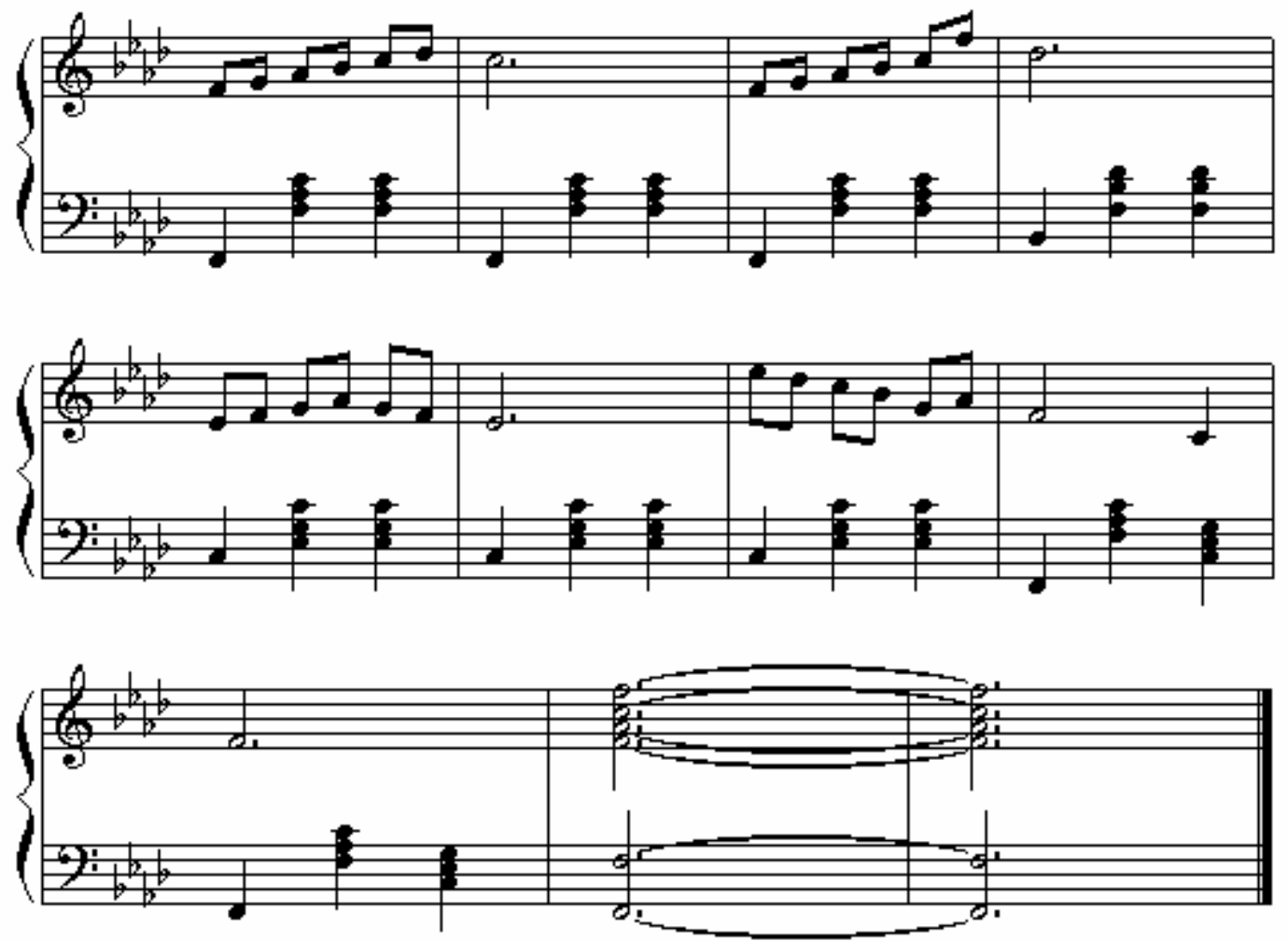


\section{Trecho musical 03 - Modo Frígio}
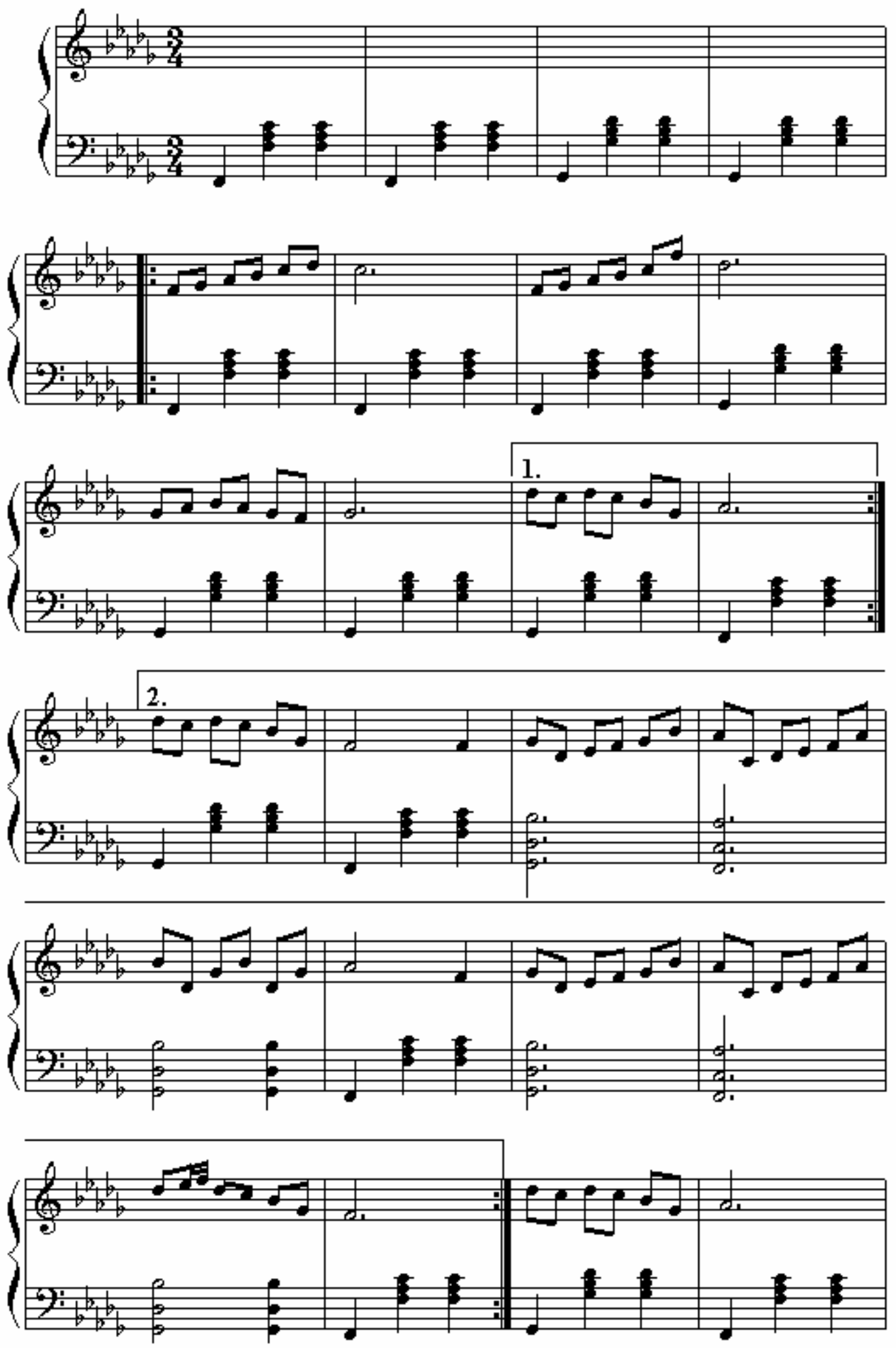

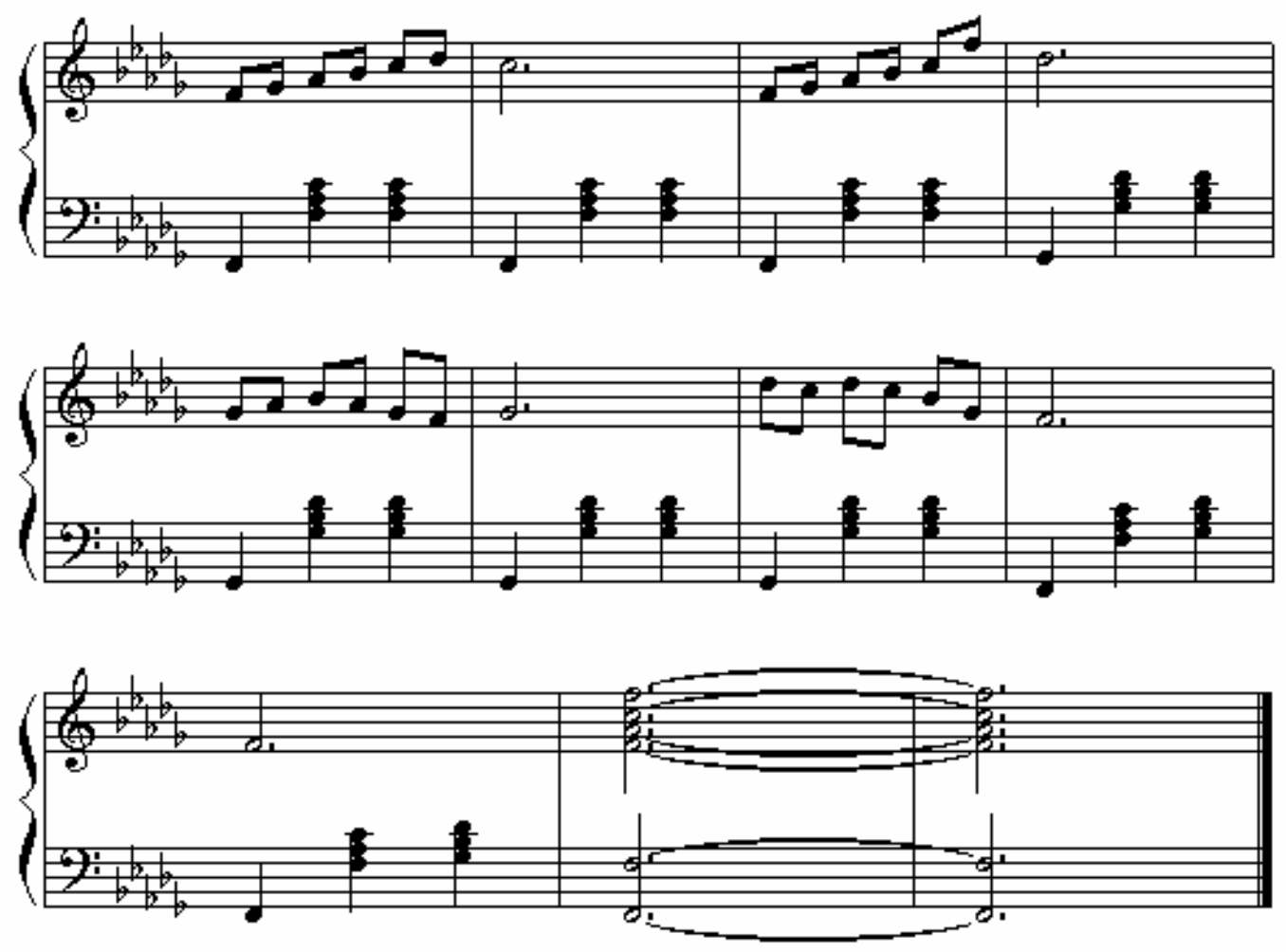
Trecho musical 03 - Modo Lócrio
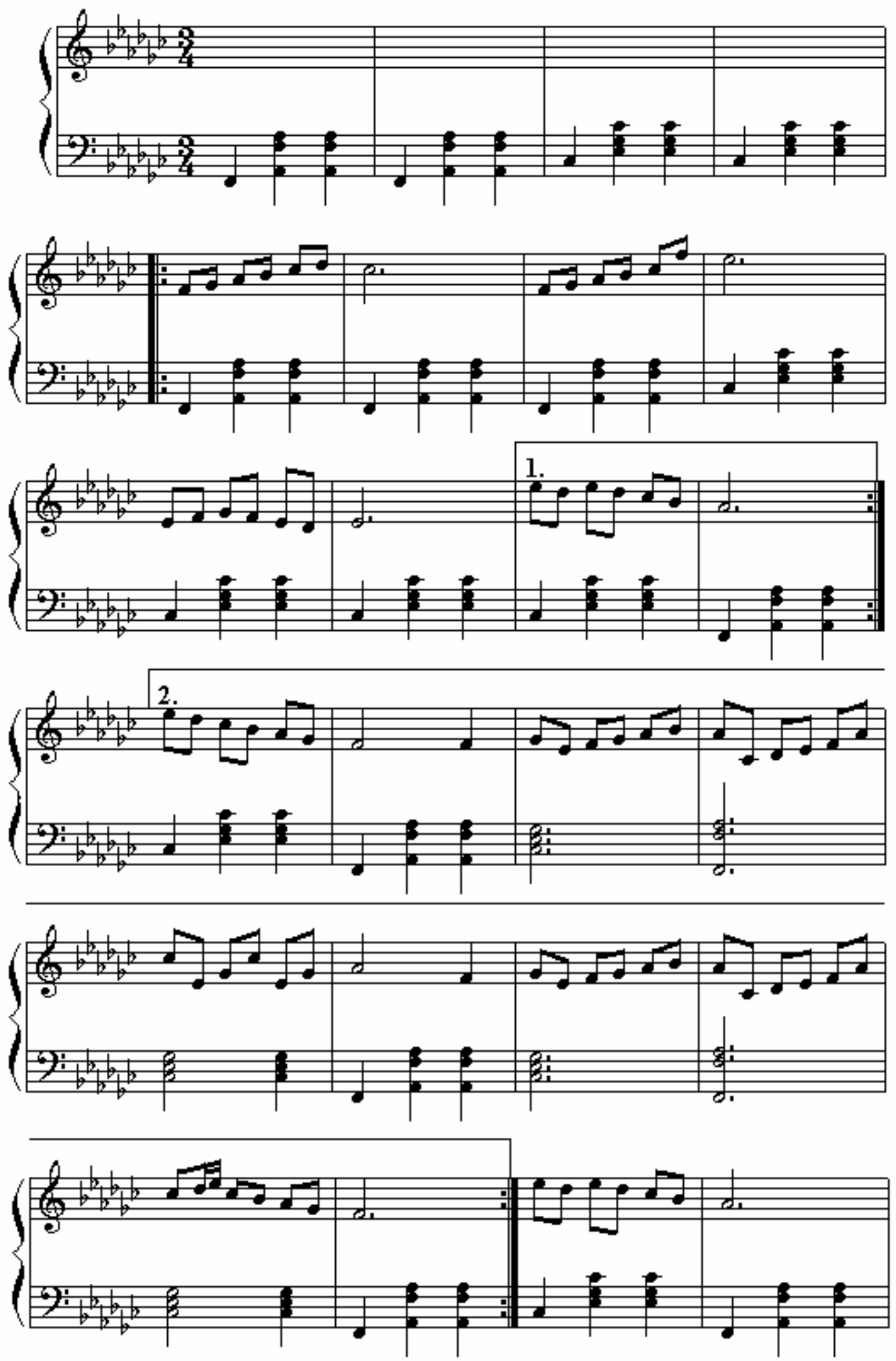

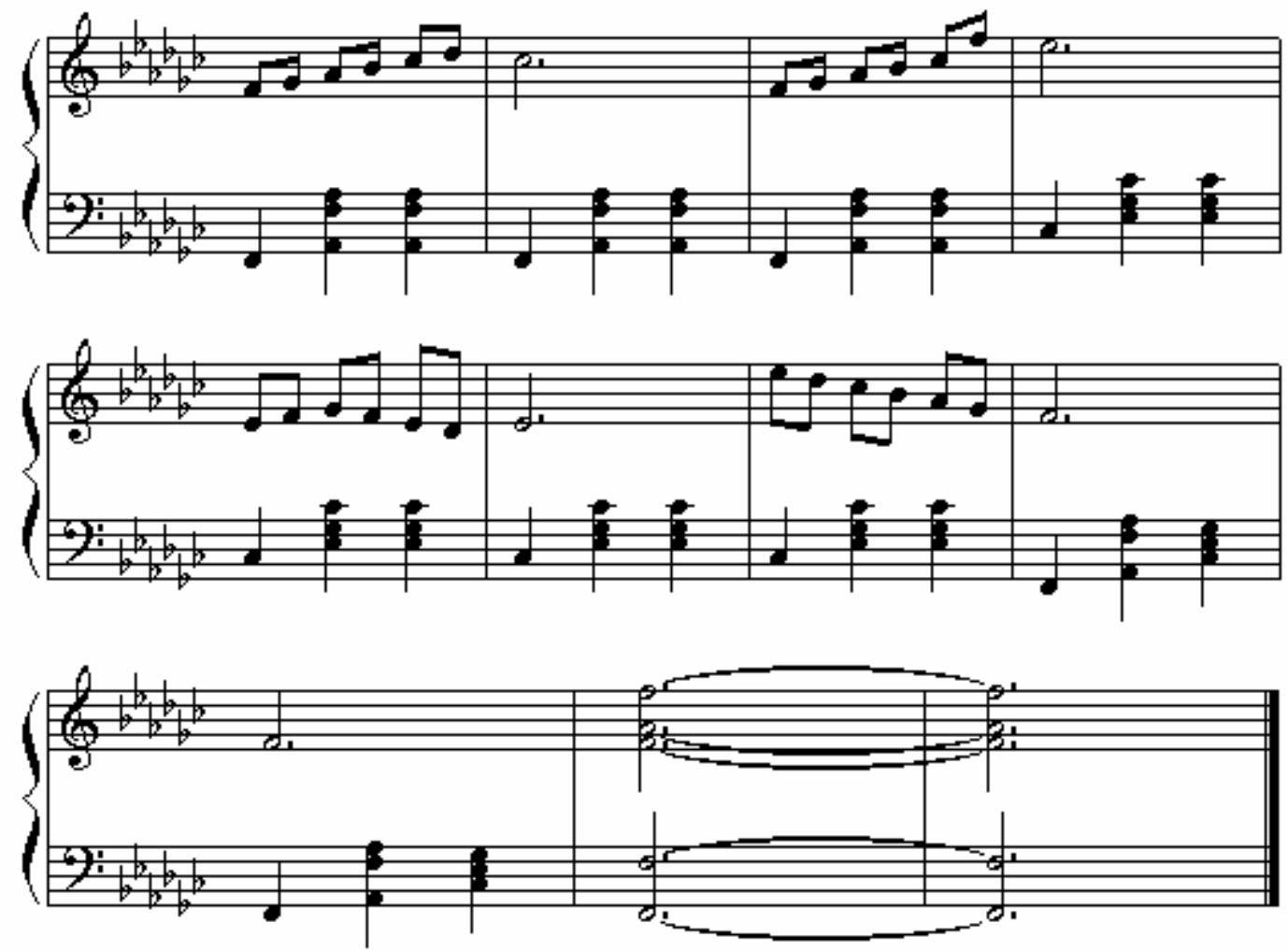


\section{APÊNDICE D}

CD - Trechos musicais (Experimentos I, II, III e IV) 